Universidade de São Paulo

Faculdade de Filosofia, Letras e Ciências Humanas

Departamento de Geografia

Programa de Pós-Graduação em Geografia Humana

Ronaldo Gomes Carmona

\author{
PODER NACIONAL E \\ GRANDE ESTRATÉGIA: \\ UMA ANÁLISE GEOPOLÍTICA \\ DOS CONCEITOS FUNDAMENTAIS \\ DO PROJETO BRASILEIRO DE POTÊNCIA.
}

São Paulo

2017 


\title{
PODER NACIONAL E \\ GRANDE ESTRATÉGIA: \\ UMA ANÁLISE GEOPOLÍTICA \\ DOS CONCEITOS FUNDAMENTAIS \\ DO PROJETO BRASILEIRO DE POTÊNCIA.
}

\author{
Tese apresentada ao Programa de Pós- \\ Graduação em Geografia Humana do \\ Departamento de Geografia da \\ Faculdade de Filosofia, Letras e \\ Ciências Humanas da Universidade de \\ São Paulo, para obtenção do título de \\ Doutor em Geografia Humana. \\ Área de concentração: Geografia Humana \\ Orientador: Prof. Titular Dr. André Roberto Martin
}

São Paulo

2017 
Autorizo a reprodução e divulgação total ou parcial deste trabalho, por qualquer meio convencional ou eletrônico, para fins de estudo e pesquisa, desde que citada a fonte.

\section{Carmona, Ronaldo Gomes}

Poder Nacional e Grande Estratégia: uma análise geopolítica dos conceitos fundamentais do projeto brasileiro de potência. /Ronaldo Gomes Carmona; Orientador: Professor Doutor André Roberto Martin - São Paulo, 2017.

XXX fls.

Tese (Doutorado - Programa de Pós-graduação em Geografia Humana, Área de concentração: Geografia Humana) - Faculdade de Filosofia, Letras e Ciências Humanas da Universidade de São Paulo 
Título: Poder Nacional e Grande Estratégia: uma análise geopolítica dos conceitos fundamentais do projeto brasileiro de potência.

Tese apresentada ao Programa de Geografia Humana, do Departamento de Geografia da Faculdade de Filosofia, Letras e Ciências Humanas da Universidade de São Paulo, para obtenção do título de Doutor em Geografia Humana.

Aprovado em:

Banca Examinadora

Prof. Dr. Instituição:

Julgamento:

Assinatura:

Prof. Dr. Instituição:

Julgamento: Assinatura:

Prof. Dr. Instituição:

Julgamento: Assinatura:

Prof. Dr. Instituição: Julgamento: Assinatura: 
O resgate e a atualização do conceitos clássicos da geopolítica e da teoria das relações internacionais quanto a Poder Nacional e Grande Estratégia são o ponto de partida do trabalho. Há uma densa e multifacética elaboração conceitual a respeito, de autores nacionais e internacionais, que se relaciona com desafios brasileiros contemporâneos tendo em vista agregar atributos de poder no sistema internacional, tendo em vista seus objetivos nacionais de realização das potencialidades nacionais e do primado do desenvolvimento para um país com as características do Brasil. Neste sentido, após a revisão conceitual e a análise das grandes tendências do cenário internacional, discutirse-á atributos brasileiros visando adquirir condição de potência. Como conclusão, o estudo busca relacionar estes debates aos documentos oficiais recentes publicados na área de Defesa Nacional que esboçam a visão geopolítica e estratégica contemporânea do Brasil.

Palavras-chave: Brasil, geopolítica, poder nacional, grande estratégia.

\section{ABSTRACT}

National Power and High Strategy are the starting point of this thesis for what we present a rescue and an updating of the classical concepts of geopoliticas and international relations theory. There is a dense and conceptualy multifaceted elaboration on this subject by national and international authors wich is related to contemporary brazilian chalenges. For a country with the brazilian's characteristics, in a way of realizing it's national potentialities and the primacy of development, is important to add attributes of power in the international system. After the conceptual review and the analysis of the great tendencies of the international scenario the Brazilian attributes are discussed aiming to acquire power condition. As a matter of conclusion the study seeks to relate these debates to the recent official documents published in the area of National Defense to outline the contemporary geopolitical and strategic vision of Brazil.

Key words: Brazil, geopolitics, national power, high strategy. 
INTRODUÇÃO. .07

\section{CAPITULO I}

Notas teóricas sobre Poder Nacional, Geopolítica e Grande Estratégia 11

CAPITULO II

A visão realista das relações internacionais

CAPITULO III

Grandes linhas e tendências prospectivas da situação internacional contemporânea. .75

\section{CAPITULO IV}

Questão nacional, identidade brasílica e coesão nacional como problema estratégico.

\section{CAPITULO V}

O planejamento da ampliação do potencial nacional e a Política de Defesa. 


\section{INTRODUÇÃO}

O trabalho que se desenvolverá a seguir, buscará refletir sobre temas recorrentes do projeto nacional, na sua dimensão estratégica, no seu "núcleo duro". Neste sentido, antes de nada, é um trabalho que enseja permanência. Afinal, as reflexões sobre os elementos constitutivos do poder nacional e suas derivações, inclusive no que diz respeito ao ambiente exógeno para realiza-lo, são desafios recorrentes no pensamento estratégico.

O sentido de permanência do trabalho que neste momento apresentamos, decorre da metodologia, das fontes e das raízes longínquas temporalmente dos quais é tributário. Falamos aqui das próprias origens da nacionalidade nos campos de Guararapes - onde pela primeira vez se escreveu a palavra pátria - na epopeia de expulsão da principal força armada do mundo à época.

Pensamos aqui no legado do português, bravo povo que após ter constituído um Estado "moderno" numa época histórica em que todavia reinavam trevas e barbárie, se lançou ao mundo numa missão original, num legado que s faz presente neste início do século XXI.

Nos referimos aqui a conceitos que guardam raiz nas origens de nosso proposito e projeto de autonomia nacional, na gênese mais profunda que deve orientar até nosso dias o projeto nacional - pois grande atualidade guarda os postulados progressistas de José Bonifácio de Andrada e Silva, no início do século XIX.

Bebemos ainda da absoluta permanência das raízes mais remotas do pensamento nacionalista que orientou a saga brasílica no século XX, que foi a grande transformação nacional que gerou um país com nível de desenvolvimento relativamente complexo, razoavelmente sofisticados ao qual se somou, neste início do século XXI, o exitoso, mas ainda incompleto, enfrentamento das mazelas sociais esdruxulas num país com tanta riqueza.

Refletimos assim sobre como um povo sentado sob um pote de ouro, pode se valer de elementos de racionalidade e planejamento para fazer suas amplas potencialidade nacionais de país do futuro, na consagrada expressão de Stefan Zweig, tornarem-se realidade e portanto, decantar a potência que todavia guarda insuficiente consciência de sua força. 
Assim, antes que nada, falamos de permanência no sentido de recobrar e reaver uma ideiaforça, uma ideia-síntese - uma ideia de Brasil - que anime e dê sentido ao projeto nacional contemporâneo num mundo repleto de desafios novos. Não se subestima aqui a força das ideias; não se tenha dúvida que são elas que movem o mundo e todas suas energias e forças materiais.

Ao mesmo tempo, buscamos aqui contribuir para a renovação destes postulados, sobretudo buscando identificar e interpretar o zeitgeist, o espírito da época, espírito do tempo ou sinal dos tempos. Não é, contudo, por esta razão, um trabalho de conjuntura, mas que busca verificar tendências da época.

Tendências de uma época em que o conhecimento humano vive crescimento exponencial. As forças produtivas se servem desta nova revolução tecno-científica - que encurta os espaços das inovações disruptivas - e produzem transformações que, tendencialmente, possibilitarão ao homem o gozo de condições materiais inéditas. Contudo, o uso sadio e racionalmente profícuo destas transformações é desafio das humanidade talvez ainda superior ao próprio fato histórico.

Falamos de renovação porque os temas que a seguir enfrentaremos também exigem mente aberta para descartar o que é datado de outra época histórica e para observar os fenômenos novos, portadores de nova época.

Assim, o fio da meada metodológico deste trabalho é o de caminhar na margem estreita - e tênue - da dialética permanência e renovação.

Contudo, este trabalho aparece num momento de apequanamento do Brasil, de desorientação estratégica e falta de rumo. No futuro, as novas gerações olharão este período histórico - breve, esperamos todos - e observarão como é correta a assertiva que fala do definhamento evidente a que é submetido um povo que está dividido, polarizado, conflagrado. A falta de unidade de propósitos, de rumo e de sentido, leva o indivíduo ou a coletividade de indivíduos - a nação - à desorientação e definhamento.

Os temas aqui apresentados e revisados entabulam dialogo com bases do projeto nacional. Alguns poderiam crer ser um contrassenso escrever sobre estes temas num momento deste, pois poderia ser interpretado como algo que se antecipa a uma premissa para suas realização, que é a pacificação nacional. Contudo, nos motivamos a percorrer este rumo 
exatamente por que nos parece que o desafio da academia e, mais amplamente de nossa sociedade é precisamente o de preparar a base de ideias para a retomada nacional.

Para situar nosso desafio aqui, tomamos emprestada as palavras de San Tiago Dantas, que em magistral conferencia à Escola Superior de Guerra, pontua a necessidade de uma "verdadeira tentativa de enquadramento sistemático de algumas ideias que ainda são hoje tratadas, em geral, sob a forma de problemas, mas que todos nós sentimos uma grande necessidade de pôr em ordem".

Dizia ele, modestamente para homem de sua estatura, "que os conceitos emitidos até aqui, nesta conferência, tem um caráter tentativo [...] confesso, que só me abalanço a fazê-lo como uma provocação, para suscitar a minha própria meditação e a dos senhores, pois, reconheço que nada se poderia fazer de valido numa pesquisa dessa ordem de grandeza, concretamente sobre um país, se não por meio de um trabalho coletivo, de uma documentação considerável, de uma investigação histórica e acima de tudo de um estudo de área, isto é, de uma comparação entre os problemas brasileiros e os problemas de outros países, que tenham, em comum com o nosso, a condição social e a etapa do desenvolvimento".

Ao tomarmos emprestados as palavras do celebre chanceler brasileiro, o fazemos para demonstrar plena consciência, por um lado, das limitações que se apresentarão no trabalho a seguir, de escopo amplo e objetivos que por certo excedem os desafios de uma pesquisa acadêmica. Necessariamente é obra coletiva que preparará a base de ideias que animará, como dissemos, a retomada do projeto nacional brasileiro. Contudo, tendo em vista a linha de investigação que temos percorrido ao longo de nossa atividade acadêmica, adicionada a algumas das atividades políticas e profissionais às quais nos dedicamos nos últimos anos, nos permitem e no s dão segurança para percorrer este caminho que seguirá nas próximas páginas.

Os dois primeiros capítulos buscam resenhar premissas teóricas, na linha do binômio renovação e permanência ao qual nos referimos nesta introdução.

O primeiro capitulo se compõe de "Notas teóricas sobre Poder Nacional, Geopolítica e Grande Estratégia”. Estas notas teóricas buscam uma revisão sistemática daquelas que consideramos as principais contribuições conceituais, quer no pensamento universal sobre questões de poder, quer na sua leitura e interpretação brasileira, pelas quais buscamos assentar as bases pelas quais se desenvolverá o trabalho. 
O segundo capitulo se denomina-se "A visão realista das relações internacionais", e tem o propósito de resenhar parte das contribuições desta corrente interpretativa das condições sistêmicas pelas quais as nações percorrem a afirmam seus caminhos e descaminhos.

O seguinte capitulo, terceiro, versa sobre "Grandes linhas e tendências prospectivas da situação internacional contemporânea". Não é uma análise de conjuntura internacional - que em pouco tempo se revelaria datada dada a exponencial evolução desta realidade -, mas tampouco despreza que o debate contemporâneo sobre o projeto nacional - sobre poder nacional e grande estratégia - possa desprezar as profundas injunções do ambiente exógeno sobre nossos rumos e opções. A busca aqui será a de buscar identificar situações estruturais mais delimitadas, e sobretudo vê-las projetandoas num horizonte mais largo, de tipo prospectivo.

Vamos ao quarto capitulo buscando versar sobre a "Questão nacional, identidade brasílica e coesão nacional como problema estratégico". Não se pode propor um debate sobre projeto nacional sem refletir sobre características singulares dos brasileiros e seu grau de unidade para se defrontar com grandiosos desafios. Não se pode desprezar - e isso está dito neste capitulo - que somente quando produzimos uma revolução interpretativa sobre nós mesmo, logramos iniciar a jornada rumo a realização da grandeza nacional. Por isso, se demonstra a relação inconteste entre pensamento social e pensamento estratégico.

Por fim, o quinto capitulo tem como título "O planejamento da ampliação do potencial nacional e a Política de Defesa". Partimos aqui do pressuposto da centralidade do planejamento e do plano na definição de caminhos racionais pelos quais a ideia de Brasil se realizará. E não subestimamos o papel da política de Defesa no estabelecimento do binômio soberania e desenvolvimento, tendo em vista suas tarefas precípuas, de natureza exógena, e suas tarefas subsidiarias - mas nem por isso secundarias, ao contrário, num país com as caraterísticas do Brasil, relativas às missões endógenas quanto a construção nacional.

São Luís, 05 de outubro de 2017. 


\section{CAPÍTULO I}

\section{Notas teóricas sobre Poder Nacional, Geopolítica e Grande Estratégia}

\section{Introdução}

O presente capítulo se propõe, com base numa revisão dos principais conceitos apresentados na literatura relativos a Poder Nacional, Geopolítica e Grande Estratégia, a estabelecer balizas teóricas que possibilitem desdobrar nos próximos capítulos, questões relativas a aspectos diversos de aplicação destes conceitos ao caso brasileiro.

Assim, trata-se aqui de realizar um estudo sistemático de conceitos estabelecidos cujo objetivo é observar desafios postos ao Brasil para ascender a uma condição de potência no sistema internacional, uma histórica e contemporânea aspiração nacional.

A ascensão do país a condição de potência, por um lado, depende das próprias forças, no sentido de acumular elementos que constituem o Poder Nacional - que por sua, vez, derivam de capacidades objetivas e subjetivas, constantes e variáveis, como veremos a seguir. Cabe, neste sentido, planejar o fortalecimento do potencial nacional.

Ao mesmo tempo, a ascensão nacional a uma condição de potência entre as nações, decorre das condições imperantes no sistema internacional, sobretudo do cenário geopolítico e geoestratégico global, que por sua vez se manifestam nas suas dimensões estrutural e conjuntural.

A condição estrutural refere-se a natureza intrínseca ao sistema internacional, a qual compreendemos, a partir de uma compressão realista, que se caracteriza em primeiro lugar pela ausência de ente regulador dos conflitos entre suas partes constitutivas (Estados nacionais). Esta situação anárquica do sistema internacional, na qual cada unidade busca manobrar no sentido de maximizar seus atributos de poder, é matizada por uma dimensão variável - por isso, conjuntural ou cíclica -, representada pela existência de uma balança de poder.

Almejar a condição de potência, para o Brasil, decorre da aspiração de reunir condições mais favoráveis a consecução de seu próprio projeto de desenvolvimento, isto é, das condições para aumentar o grau de autonomia, sua margem de manobra para seus interesses vitais mais nucleares visando o bem estar geral, o progresso material e 
espiritual de sua civilização. Para isso, se deparará com o desafio de remover obstáculos diversos, vigentes ou potenciais, de natureza exógena e endógena. Afinal, é questão consolidada na escola geopolítica brasileira a ideia de que o Brasil é um país satisfeito territorialmente, dada suas caraterísticas físicas e geográficas, excedentes de recursos naturais - dentre eles, minerais e aquíferos -, vastas extensões de terras agricultáveis. Nossa busca por maximizar elementos de poder nacional decorre essencialmente da objetivo nacional mais vital é a construção de uma pátria prospera, com elevado bem estar coletivo de seu povo.

Este capítulo discutirá construções teóricas clássicas, tanto de autores estrangeiros como de suas interpretações por autores nacionais. Primeiramente, apresentaremos as definições consolidadas a respeito dos três conceitos que aqui enunciamos: poder nacional, geopolítica e grande estratégia. Em seguida, discutiremos como estes conceitos se apresentam na interpretação de três autores nacionais: um ícone da vertente militar da geopolítica brasileira (Golbery do Couto e Silva) e dois dos maiores representantes da vertente autonomista da política externa brasileira - também conhecida como política externa independente (PEI) -: San Tiago Dantas e Araújo Castro. Por fim, a terceira parte deste primeiro capitulo apresentará a contribuição de autores internacionais clássicos no pensamento realista para as temáticas em tela.

a) Definições conceituais

Nesta sessão, fixaremos o entendimento conceitual das ideias de Poder Nacional, Geopolítica e Grande Estratégia. Trata-se de um ponto de partida necessário para prosseguir no estudo da aplicação destes conceitos ao caso brasileiro.

O conceito de Poder Nacional, como veremos, é longamente desenvolvido na literatura. Especialmente, consideramos bastante completa a decomposição de seus elementos em Morgenthau. No caso brasileiro, o esforço para a definição e desenvolvimento do conceito ocorre principalmente no âmbito da Escola Superior de Guerra (ESG), instituição fundada em 1949, como espaço acadêmico, que desde então, em maior ou menor grau, sempre exerceu função chave no pensamento estratégico nacional.

A definição hodierna do conceito de poder nacional pode ser encontrada no Manual denominado Glossário das Forças Armadas, publicação que busca harmonizar e 
consolidar conceitos comuns às três Forças singulares, tendo em vista objetivos de interoperabilidade.

Assim, por Poder Nacional, entende-se "a capacidade que tem a Nação para alcançar e manter os objetivos nacionais, em conformidade com a vontade nacional. Manifesta-se em cinco expressões: a política, a econômica, a psicossocial, a militar e a cientificotecnológica" (grifo nosso, 2015, p. 212). Os objetivos nacionais, por sua vez, são definidos como "aqueles que a Nação busca alcançar, em decorrência da identificação de necessidades, interesses e aspirações, ao longo das fases de sua evolução históricocultural" (2015, p.186).

Sobre a definição de geopolítica, há uma profusão de conceituações, em geral convergentes ${ }^{1}$. Tomaremos aqui a sintética e ao mesmo tempo densa formulação de Beckheuser - também a definição preferida do General Golbery -, para quem, geopolítica "é a política feita em decorrência das condições geográficas".

Como explica Golbery (1967, p.64),

"Para nós, a Geopolítica nada mais é que a fundamentação geográfica das linhas de ação política, quando não, por iniciativa, a proposição de diretrizes políticas formuladas à luz dos fatores geográficos, em particular de uma análise calcada, sobretudo, nos conceitos básicos de espaço e posição. Um dos ramos, portanto, da política, como imaginava o próprio Kjellén e sempre a qualificou, entre nós, o mestre Beckheuser: 'política feita em decorrência das condições geográficas”.

Cabe aqui destacar questão que nos parece essencial na definição de geopolítica. Tratase de definição de Hans W. Weigert (1942, p. 22-23), para quem:

"Não existe algo como uma ciência geral da geopolítica, que possa ser subscrita por todas as organizações estatais. Há tantas geopolíticas quantos os sistemas estatais em luta sob condições geográficas, as quais, no caso do poder marítimo e do poder terrestre são fundamentalmente diferentes. Há uma "Geopolitik", uma "geopolitique" [...] Cada nação tem a geopolítica que pretende [...]"

Ou seja, por definição, a geopolítica é nacional; atende a interesses políticos de um determinado Estado-nação, dada suas condições geográficas única. Por certo, existem grandes formulações universais da teoria geopolítica, como se observa em seus grandes clássicos. Ainda assim, mesmo princípios gerais, por exemplo, afeito a preponderância

\footnotetext{
1 Os vários conceitos de Geopolítica, tanto de autores nacionais como estrangeiros, estão resenhados em CARMONA, 2012, P. 11-18.
} 
marítima ou continental de um dado território, estes se realizam na singularidade do território em questão.

Essa ideia da geopolítica nacional guarda raízes na definição de Clausewitz sobre o fato de que a guerra deveria ser "nacional”. Como explica Anatole Rapoport, no prefacio ao clássico Da Guerra, “a guerra 'deveria' ser nacional, para que seu objetivo fosse a satisfação dos interesses de um Estado nacional e para que se justifique que todo o esforço de uma nação seja mobilizado a serviço do objetivo militar" (CLAUSEWITZ, 2010, P. XIII).

Na mesma chave, observa Oliveiros Ferreira que,

"A geopolítica só tem sentido se serve para fundamentar na geografia o projeto que um partido afirma ser o Destino Manifesto da Nação - destino que se demonstra estar inscrito na posição ou na situação geográfica, e que deve ser traduzido por uma política de Estado destinada a tornar realidade o que a geografia permitiu vislumbrar". "...a mentalidade geopolítica conduz, pela lógica interna da proposição inicial, a uma política de poder realizada a fim de fortalecer o Estado frente aos demais; é, pois, uma política nacional para não dizer nacionalista e tendente ao expansionismo. Pouco importa, nessa caracterização sumaria, se a expansão se dará para além das fronteiras nacionais, a fim de conquistar o Lebensraum (espaço vital) que o Estado julga indispensável à realização de suas potencialidades, ou para dentro de suas próprias fronteiras, colonizando o território já legalmente dominado, mas não socialmente ocupado" (p.24).

Portanto, a relação absoluta entre geopolítica e política de poder, nos leva a observação de seus vínculos com o conceito de Poder Nacional. Da mesma forma, permite-nos corroborar, o que ao início deste capitulo afirmamos, que o expansionismo da geopolítica brasileira refere-se ao aproveitamento integral das amplas potencialidade de seu próprio território, suficiente para dar cabo das aspirações e dos atributos de poder que necessita o Brasil.

Em suas Notas sobre o conceito de potência, Ângelo Del Vecchio observa que,

"Ponto de forte controvérsia, e um dos divisores de água entre as vertentes realista e liberal" é o transporte de "características e valores da política nacional para o campo da política internacional". Valores aparentemente inquestionáveis são transpostos para o plano de ação externa de um Estado. "Ressalvadas as exceções do direito internacional, o Estado, no plano externo, não reconhece limites de natureza legal ou moral. É sob essa 'ausência' de limites que ocorre o embate entre o interesse de cada Estado nacional e dos seus congêneres, processo no qual se dá a afirmação da identidade desse mesmo Estado nacional especifico no âmbito internacional. Nessa perspectiva, a experiência concreta de cada Estado é única e irredutível; expressa sempre uma tentativa de exercício ininterrupto da soberania". A questão da ficção e conflito na relação entre Estados nacionais tem leitura clássica em Hobbes, que em seu Leviatã, relaciona o comportamento das unidade do sistema internacional ao do estado da natureza, no qual cada detentor da soberania se 
comporta como "gladiadores, com as armas assestadas, cada um de olhos fixos no seus vizinhos". O leviatã hobbesiano é "portador de dupla soberania: interna, que garante a integridade e a prosperidade dos súditos, com os quais está coletivamente pactuado, e externa, que lhe garante a "absoluta liberdade de fazer tudo o que considerar mais favorável (...) aos seus interesses" (2010, p.23).

A relação entre a dimensão endógena e a exógena da soberania, acima retratada, é fundamental para observar limites e potencialidade do Poder Nacional se definição de seus objetivos fundamentais.

Por fim, busquemos a definição de Grande Estratégia - no original High Strategy -, proposta pelo escritor britânico Liddel Hart. Para ele,

“[...] o termo 'grande estratégia' serve para dar um sentido de 'execução de uma política', pois seu papel é o de coordenar e dirigir todos os recursos de uma nação ou de um grupo de nações, para a consecução do objetivo político, visado com a guerra, que é definido pela política. A grande estratégia deve avaliar e fortalecer os recursos econômicos e o potencial humano das nações a fim de suportar as forças armadas. Não se deve esquecer os fatores morais, pois incentivar o espírito combativo de um povo é muitas vezes mais importante do que possuir formas mais concretas de poder. O poder militar é um dos instrumentos com que conta a grande estratégia para, juntamente com a ação financeira, diplomática, comercial e particularmente ética, enfraquecer a vontade de luta do adversário" (apud Escola de Guerra Naval, p.4/VI-5, 1998).

Como se pôde observar, há uma forte correlação entre o conceito de Poder Nacional e o de Grande Estratégia. Podemos dizer que as linhas da Grande Estratégia são tão mais exequíveis em função dos meios (o Poder Nacional) que a sustentam.

Segundo Golbery, "o grande mérito de Liddell Hart foi demonstra-lo" - o conceito de Grand Estratégia -, "situando a Estratégia em sua verdadeira missão que não é, de forma alguma, restrita a de ganhar decisivas batalhas, mas sim, muito mais ampla e variada, a de atingir determinados fins - políticos, econômicos ou psicossociais - mediante o emprego eficaz dos meios militares, através da batalha se necessário, pela manobra sem batalha sempre que for possível”. (COUTO E SILVA, 1967, p.149).

Inevitável, nesta conceituação, ir a Clausewitz, na sua definição mais conhecida, em $D a$ Guerra - o grande clássico do pensamento estratégico ocidental -, publicado após sua morte, em 1832-1837. Refiro-me a ideia que de conceber a guerra como instrumento da política.

Essa ideia chave deve ser compreendida em sua inteireza para efeitos do debate que aqui apresentamos. Pode-se dizer que, ainda que a guerra tenha sua forma própria, não possui uma lógica que seja distinta daquela da política. Afinal, com a guerra não deixam de existir as relações políticas, tampouco estas passam a ser algo distinto, tendo em vista que 
a guerra não é outra coisa senão a continuidade das relações políticas, agora pelo acréscimo de novos meios, no caso, a violência.

Cabe ainda, na sessão de clarificação conceitual, observar as diferenças que há na relação hierárquica entre política e estratégia no domínio da ciência política e social e no domínio do pensamento estratégico.

No caso das ciências sociais, os objetivos estratégicos são os de maior alcance, ao passo que a política refere-se a objetivos de escopo inferior em relação à estratégia.

No caso do pensamento estratégico, a hierarquia é oposta. Novamente apoiando-nos no Glossário da Forças Armadas (edição 2015), política é a "arte de estabelecer objetivos e de orientar e conduzir o processo global que visa à conquista e manutenção destes objetivos" (2015, p. 213). Já estratégia compreende-se como "arte de preparar e aplicar o poder para conquistar e preservar objetivos, superando óbices de toda ordem" (2015, p.109). Por isso, a Política Nacional de Defesa, como veremos adiante, é o documento de mais alto nível e a ele se subordina o "como fazer", na forma da Estratégia Nacional de Defesa. Já a Política é o que expressa "o que fazer". Para o debate vinculado ao pensamento estratégico, faz todo sentido, uma vez que estratégia é a arte do general, isto é, a aplicação da política no terreno. Para efeitos deste trabalho, adotaremos esta conceituação.

b) Contribuição de autores nacionais

\section{A contribuição de Golbery}

O General Golbery do Couto e Silva, talvez o principal geopolítico brasileiro no período da guerra fria - mais exatamente entre os anos 1950 e $1980^{2}$-, traz um legado expressivo para os dias atuais. A notável contribuição teórica, na qual sobressai o clássico Geopolítica do Brasil, agregue-se sua posição de poder, como oficial que esteve à frente

\footnotetext{
2 Se não "o principal", certamente compõe uma tríade com ou General, Meira Mattos e com a professora de geografia, Terezinha de Castro, como os principais formuladores da Geopolítica brasileira nesta período assinalado.
} 
em posições de comando por vaias décadas, chagando a chefia a Casa Civil da Presidência da República. Ou seja, sua elaboração teórica não representou tão somente uma abstração acadêmica, mas representou, pelas posições de poder que ocupou, capacidade real de realização de seus postulados e proposições.

É preciso olhar hoje, em 2017, com uma visão crítica da contribuição de Golbery. Obra de referência que se propôs a fazê-lo, com grande originalidade, foi a tese de livre docência do professor André Martin, do Departamento de Geografia desta Universidade - e orientador desta tese de doutoramento - denominada "Brasil, Geopolítica e Poder Mundial: o anti-Golbery" (2007). Nela, Martin identifica que,

"Se Golbery e o pensamento geopolítico esguiano de um modo geral, tiveram o mérito de colocar o Brasil no mundo, superando em termos de perspectiva analítica, o confinamento sul-americano de seus predecessores, os compromissos ideológicos de defesa do 'Ocidente em perigo', por outro lado, os obrigou a retroceder ao velho ponto de vista 'meridianista', em que o Atlântico Sul possui apenas um valor defensivo" (2007:105)

Esse aspecto meritório que observa Martin, pode ser situado em Golbery (1967, p.213), quando diz que "o Brasil está magistralmente bem situado para realizar um grande destino tão incisivamente indicado na disposição eterna das massas continentais, quando lhe soar a hora, afinal, de sua efetiva e ponderável projeção além-fronteiras". Em seguida, premonitório, antecipando tendência que só apareceria nos documento de Defesa contemporâneo - mais especificamente, pela primeira vez, no texto da Política de Defesa Nacional de 2005 -, que "a posição do Brasil não está também mal resguardada, em verdade, com relação aos centros de poder mais dinâmicos de onde poderão surgir, em qualquer época, agressões de grande porte".

Cabe aqui desenvolver tema clássico da geopolítica, a respeito da posição do território tendo em vista os centro mais dinâmicos de poder. É recorrente em autores como Mahan, Mackinder ou Spykman, a observação, quanto ao caso norte-americano, das vantagens derivadas da insularidade territorial. O Brasil possui condição de relativa distância quanto às zonas de maior tensão geoestratégica contemporânea: o Leste da Ásia, o “grande Oriente Médio" e a Eurásia. Por outro lado, em nosso entorno geográfico, como lembra Martin (2007, p.116), "não temos em nossa retaguarda um poder terrestre que nos desafie, nem diante de nós uma potência marítima que concorra com nossas pretensões comerciais”. O outro lado da moeda, dessa vantagem da posição do território e ausência de poder belicoso na vizinhança, porém, pode ser uma falsa sensação de segurança pelos 
brasileiros, que dado o cenário prospectivo global, como veremos em outras partes deste trabalho, se apresenta cada vez mais desafiador para um país com as características e as potencialidade do Brasil.

Na análise de Golbery, Martin, ao "meridianismo" opõe o conceito de meridionalismo, numa original interpretação proposta a partir da posição geográfica brasileira, sendo nosso país "o centro desse mundo" pois aqui ocorreram "as mais importantes vitorias contra o colonialismo: a desmoralização das teorias racistas e do determinismo geográfico" (2007, p.113). Assim, o foco da posição do "anti-Golbery" é opor a posição ocidentalista de Golbery à sua posição meridionalista.

A virtude do trabalho de Martin é exatamente a de localizar, no que diz respeito a Golbery, o núcleo do seu anacronismo: a "contaminação" de sua arguta visão geopolítica pela clivagem ideológica da guerra fria, nos situando numa situação de subordinação ao sistema comandado pelos Estados Unidos e desconsiderando, ser o Brasil, vértice de uma civilização original, dotada de projeto de poder próprio no sistema internacional. Nesse sentido Golbery retrocede em relação a um dos fundadores da geopolítica brasileira, Mario Travassos, que em seu clássico, Projeção Continental do Brasil manifestava preocupação com a penetração norte-americana a partir da construção do canal do Panamá.

Essa "contaminação ideológica" da geopolítica brasileira é fator em franca superação ${ }^{3}$. Como argumenta o atual comandante do Exército Brasileiro (EB), General de Exército Eduardo Villas Boas, em audiência na Câmara dos Deputados, ocorrida em cinco de julho de 2017, cometemos um erro enquanto país ao permitir que a linha de confrontação da guerra fria afetasse nossa coesão nacional. Voltaremos a este tema - originalidade de nossa formação social e coesão nacional como fatores geopolíticos - num próximo capitulo deste trabalho.

Na crítica ao que permanece e no que é superado na contribuição geopolítica de Golbery, cabe aqui também ouvir o arguto professor Oliveiros Ferreira, quem nos remete a citada visão acima de Hans W. Weigert quem observa o caráter nacional da geopolítica. Diz Ferreira (1988, p. 25),

"A operação mental que o General Golbery pretende fazer - construir uma geopolítica brasileira para auxiliar os Estados Unidos e o Ocidente a defender-se contra 'o

${ }^{3}$ O termo ideológico aqui utilizado numa acepção negativa, no sentido de fratura da coesão nacional. 
imperialismo comunista de origem exótica' - é de difícil realização, porque nega o fundamento mesmo do raciocínio geopolítico, que é a política de poder e a afirmação do Poder Nacional desvinculado do contexto mais geral da civilização em que se insere".

Retornando a Golbery, se, por certo, parte de suas considerações são datadas do período da guerra fria, outras permanecem validas. Em especial, tem grande importância sua fundamentação a respeito do arcabouço conceitual, em plena vigência, com adaptações, a respeito do planejamento de Defesa brasileiro. No livro, Golbery propõe bases metodológicas de um Conceito Estratégico Nacional, como "diretriz fundamental que, em dado período, deve nortear toda a estratégia da Nação, com vistas à consecução ou salvaguarda dos Objetivos Nacionais" (1967, p.251). Tendo em vista o interesse desse trabalho, a discussão do Poder Nacional, é grande e atual a contribuição que se pode observar em Golbery. Afinal, podemos afirmar que o enquadramento conceitual das dimensões hierárquicas do pensamento estratégico brasileiro contemporâneo encontramse definidas no clássico Geopolítica do Brasil.

Assim, no que diz respeito ao planejamento do Poder Nacional, Golbery (1967, p.25) observa a seguinte hierarquização,

"Temos assim, na cúpula da segurança nacional, uma Estratégia, por muitos denominada Grande Estratégia ou Estratégia Geral, arte de competência exclusiva do governo e que coordena, dentro de um Conceito Estratégico fundamental, todas as atividades políticas, econômicas, psicossociais e militares que visem concorrentemente à consecução dos objetivos nos quais se consubstanciam as aspirações nacionais de unidade, de segurança e de prosperidade crescente" (p.25)

Como dissemos anteriormente, aqui se observa a clara influência do pensamento fundador de Clausewitz no sentido de subordinar a Estratégia à Política. Como se vê na citação acima, Golbery equipara, corretamente, o conceito de Grande Estratégia ao de Política, isto é, de orientação maior do Estado. Prosseguindo nessa linha, diz ainda o autor que,

"A Estratégia de hoje é, assim, a arte de fortalecer e aplicar, tanto na guerra como na paz, o Poder Nacional, para superar ou vencer - em certos casos, apenas diferindo ou contornando - os antagonismos que se manifestam ou possam a vir se manifestar-se, no campo interno ou no âmbito internacional, em oposição mais ou menos frontal aqueles Objetivos Nacionais. Parte escelsa da Política, a Estratégia veio a ser, afinal, toda a Política de Segurança Nacional” (1967, p.153)

É válido revisitar a configuração geopolítica do território nacional proposta por Golbery, para ele conformada por três grandes áreas: 
- uma zona estratégica que ele denominou de "reserva geral", composta pelo núcleo central ecumênico a partir do triangulo "altamente vitalizado" de Rio - São Paulo - Belo Horizonte;

- à Oeste, duas zonas estratégicas terrestres, a Amazônica e a Platina, unidas por uma zona estratégica de soldadura que abarca o Mato Grosso (hoje representado por dois Estados, MT e MS), Paraguai e Bolívia;

- à Leste, duas outras zonas estratégicas, ambas de natureza oceânica: a do Atlântico centro-norte e a do Atlântico centro-sul, ambas articuladas por outra zona estratégica de soldadura representada pelo promontório nordestino.

Creio que, essencialmente, essa divisão geopolítica segue tendo sua validade no que diz respeito a tarefas pendente tanto de integração nacional, quando do enfrentamento de nossa condição de "Estado-anfíbio" representada por nossa dupla condição de maritimidade e continentalidade.

A "reserva geral", se alargada a Brasília, constitui o núcleo político-econômicodemográfico brasileiro é a área estratégica cuja proteção constitui preocupação essencial para a preservação das bases mais nucleares do Poder Nacional.

À Oeste, nossas fronteiras devem observar a diversidade fisiografia entre os três sistemas do Brasil e da América do Sul:

- a Amazônia, que demanda tarefas endógenas, relativas à sua definitiva integração ao todo do território nacional e no âmbito regional, de políticas relativas à pan-Amazônia;

- o Andino, com suas singularidades, no pleno regional, se se desdobra na grande planície central (como zona de soldadura), internamente na vastidão do Centro-Oeste brasileiro e no além fronteiras, na região que vai da região boliviana de Santa Cruz de la Sierra ao Paraguai;

- finalmente quanto ao sistema Paraná-Prata, que junto a região Sul do Brasil, sugere política de planejamento estratégico próprio.

No três casos à Oeste, avulta a questão do acesso brasileiro ao Pacífico, antiga aspiração geopolítica nacional desde Travassos. Recentemente, no âmbito da cooperação do a China, está em tela a proposta de construção de uma ferrovia transcontinental pelo Peru. 
Quanto a parte Leste do território nacional, primeiramente, é correta a compreensão da particularidade atlântica com a qual se defronta nosso país. O Brasil tem se oposto, corretamente, às teses expansionistas, propostas a partir de centros de estudos estratégicos de países da OTAN, que buscam lançar o conceito de "bacia atlântica", desconhecendo a vastidão e a diversidade geográfica, econômica e social do vasto oceano.

O Atlântico centro-sul atende a especificidade de nossa ponte com a África ocidental, parte constitutiva do entorno estratégico atual do Brasil. Tem forte presença geoestratégica do OTAN, através do "cordão de ilhas" de possessão colonial remanescente da Grã-Bretanha e França, do qual se destaca a Ilha de Ascensão e o problema das Ilhas Malvinas. A utilização militar da ilha de Trindade é tema pendente de definição estratégica. Possui grande relevância como rota de comércio.

Já o Atlântico centro-norte - que podemos definir como região geográfica que abarcando a Foz do Amazonas, vai da Baia de São Marcos (MA) ao Oiapoque (AP), é, ao mesmo tempo, nossa defrontação geográfica com o hemisférico norte - área geográfica da OTAN - e nossa maior fonte de vulnerabilidade em termos de proteção militar naval. Urge o país pôr em marcha a constituição da Segunda Esquadra da Marinha do Brasil em São Luís (MA), como parte decisiva de planejamento de adensamento da presença militar brasileira na sua parte marítima norte. Também em São Luís está outra área geoestratégica de interesse de segurança nacional

Esta região também vai tomando papel central em termos geoeconômico, como rota de escoamento de comercio, sobretudo da produção mineral e agrícola, a partir do sistema multimodal (hidro-ferroviário) que desembocará no Porto do Itaqui. Terá papel crescente tanto no fluxo de comércio para o hemisfério norte, como para a Ásia, com a ampliação do canal do Panamá.

Por fim, cabe examinar o papel do premonitório nordestino, a "zona de soldadura" à Leste na definição de Golbery. Antes que nada, do ponto de vista estratégico, cabe destacar a condição de área de maior proximidade entre a América do Sul e a África, no trecho Natal - Dacar. Deste ponto de vista, urge um forte planejamento do adensamento da presença brasileira no Senegal e nos países vizinhos. 
Golbery apresenta uma importante contribuição, para os objetivos deste trabalho, num texto anterior, apresentado na Escola Superior de Guerra em 1956 pelo ainda Coronel, intitulado "Planejamento do fortalecimento do potencial nacional".

Sua visão a respeito do Planejamento é de grande importância resgatar, tendo em vista as finalidade aqui trabalhadas. Para ele, trata-se de "um sistema de escolhas sucessivas e hierárquica entre alternativas que se prefiguram, dentro de um universo de conhecimentos em expansão dirigida, com o propósito de racionalizar e orientar a ação com vistas a consecução de determinados fins - dadas, de um lado, certa disponibilidade estimada de recursos e, de outro, uma série, também estimada, de obstáculos".

Desenvolvendo sua visão quanto ao planejamento, afirma o Cel. Golbery que "não tivéssemos medo ao espectro de Marx, nascido com Feuerbach de "sob a asa esquerda" da filosofia de Hegel, poderemos avançar a afirmação, a nosso ver plenamente justificada, de que o planejamento é, de fato, um processo dialético, evoluindo sempre mediante a conciliação, em plano superior, das teses e das antíteses que definem suas contradições imanentes".

Assim, as principais antinomias que se manifestam no domínio do planejamento são:

$\mathrm{a}-\mathrm{a}$ antinomia dos meios e dos fins;

$\mathrm{b}-\mathrm{a}$ das necessidades e das possibilidades.

A questão do planejamento estratégico escolhas a serem enfretadas seja pela paz ou pela guerra. Tendo em vista que o planejamento do fortalecimento do potencial nacional “objetiva fundamentalmente, mediante ações estratégicas de toda natureza conduzidas sempre solidariamente nos campos político, econômico, psicossocial e militar" - isto é, pleos elementos de Poder Nacional -, estes podem ser enfrentados:

"De um lado, a superação, neutralização, redução ou pelo menos diferimento, por meios pacíficos, dos antagonismos que se manifestam (ou ainda, preventivamente, dos que se prevê possam a vir a manifestar-se), tanto no âmbito interno, como no campo internacional, em oposição os Objetivos Nacionais Permanentes;

De outro lado, a segurança de contar, ao cabo dos prazos críticos admitidos, com as melhores condições possíveis para enfrentar a guerra, em qualquer das várias hipóteses consideradas" 
Por fim, na contribuição de Golbery a questão do planejamento, distinguindo o que é vital dentre os objetivos nacionais daqueles apenas desejáveis. Nesse sentido, é importante resgatar a menção, feita pelo autor, a Louis J Halle, quem diz que,

"É necessário ter presente a distinção entre objetivos simplesmente desejáveis e objetivos de natureza vital. Os primeiros, os apenas desejáveis, podem não se justificar que se submetam estes, os vitais, a certos riscos extremos. Mas os objetivos vitais não nos deixam margem para escolhas - impõe-nos o criar, a qualquer sacrifício que seja, meios suficientes para sua consecução".

Em síntese, como observamos aqui, nessa breve apresentação deste que é um dos mais destacados geopolíticos brasileiros contemporâneos, pudemos observar contribuições efetivas a atuais ao debate sobre a questão do Poder nacional, bem como observar questões anacrônicas, tendo em vista a compreensão da realidade do mundo e dos desafios do Brasil nesse contexto.

\section{A contribuição de San Tiago Dantas}

O jurista e professor Francisco Clementino de San Tiago Dantas, apesar do falecimento precoce, aos 52 anos de idade, foi um dos grandes formuladores e executores da proposta de uma política externa fortemente voltada a maior autonomia brasileira no sistema internacional. Foi ele que cunhou, na condição de chanceler do presidente João Goulart, a expressão política externa independente (PEI) - que junto com o pragmatismo responsável, conduzido pelo chanceler Azeredo da Silveira, durante a presidência de Ernesto Geisel, e a política externa "altiva e ativa" do chanceler Celso Amorim, no período Lula, são consideradas as grandes experiências contemporâneas na busca de uma inserção autônoma do país no cenário internacional. Guardam os momentos de auge, na fase mais recente, de políticas que guardam relação profunda com as orientações dos próceres fundadores de nossa diplomacia, nosso primeiro chanceler, José Bonifácio de Andrada e Silva e o Barão do Rio Branco.

Resgataremos aqui especialmente, tendo em vista a finalidade do presente trabalho, as contribuições de San Tiago Dantas quanto a discussão sobre Poder Nacional. Utilizaremos aqui a celebre conferencia, intitulada "Poder Nacional. Seus moveis, interesses e aspirações: realismo e idealismo políticos", apresentada na Escola Superior de Guerra, em 1953, e recém publicada em livro por ocasião do centenário do 
desaparecimento de Dantas ${ }^{4}$. O texto mostra que San Tiago Dantas, deu relevante contribuição a formulação, no âmbito da Escola Superior de Guerra, do conceito de Poder Nacional - sendo a ESG o principal centro formulador deste conceito.

Para San Tiago Dantas, numa definição sintética, “o Poder Nacional pode ser definido como sendo a soma dos meios de que dispõe o Estado Nacional com o fito de assegurar, na ordem internacional, o preenchimento de seus fins". Para ele, entretanto, "na noção de Poder Nacional não se devem inserir, por uma questão de método, todos os meios que o Estado dispõe para atingir seus fins. Ficam excluídos seus meios de ação interna, e incluídos apenas os que se empregam na ordem externa ou internacional”. Ou seja, para Dantas, "a noção de Poder Nacional está, por conseguinte, intimamente ligada à técnica das relações internacionais de um Estado". Trata-se aqui de uma peculiar interpretação, que considera tão somente os meios empregáveis, na ação tendo em vista a agregação do poder nacional no sistema das Nações.

Dantas também diferencia os interesses conforme sua natureza. Para ele, "Há interesses que podemos chamar de opcionais; e há interesses que podemos chamar de vitais. $\mathrm{O}$ interesse opcional é suscetível de ser abandonado pela política de um Estado (...) O interesse vital, ao contrário, é aquele que toma um caráter imperativo, que se relaciona com as próprias condições existenciais da comunidade política". Assim, argumenta, "Os interesses vitais estão geralmente ligados à manutenção da forma histórica de uma sociedade política qualquer, ou à garantia de suas possibilidades de atingir um certo nível de desenvolvimento".

A seguir, ele analisa os conceitos de interesse e aspiração nacional. Para Dantas, "uma aspiração nacional nada mais é que a forma subjetiva que o interesse vital assume quando se projeta na consciência de suas classes, tanto de suas classes dirigentes quanto de suas classes dirigidas. Interesse nacional e aspiração nacional são, por conseguinte, a mesma coisa conforme consideramos seu aspecto objetivo ou subjetivo".

Faz enorme sentido contemporâneo o resgate da ideia sobre como os interesses vitais de uma nação se projetam tendo em vista as classes sociais, pois ela tem relação com a prorpia capacidade de uma classe dirigente de uma época, preservar esta mesma direção

\footnotetext{
${ }^{4}$ Trata-se de um texto, até 2014 desconhecido pelo público, guardado nos arquivos da ESG, que vieram a tona em livro então publicado, estando a Escola sob a direção do atual Comandante da Marinha do Brasil, Almirante de Esquadra Leal Ferreira.
} 
da condução da Nação. Afinal, da "incapacidade de compreender os seus interesses básicos existenciais é, porém, numa sociedade, o sinal inequívoco de que a sua classe política dirigente perdeu a capacidade de conduzi-la e, se uma outra classe não substitui oportunamente a primeira, é a própria sociedade que manifesta a sua mais grave crise vital: a incapacidade de interpretar culturalmente a sua própria realidade”.

Em seguida vem a tona questões relativas a capacidade de um país lograr uma condição de Unidade nacional. Para Dantas, "pode suceder que todos os indivíduos, ou pelo menos todas as classes em que se estratifica a sociedade nacional, apreendam, sob a forma consciente de representação e princípios normativos ou sob a forma inconsciente de reações instintivas e prevenções, os interesses vitais que condicionam o comportamento externo do Estado. Essa participação de todos no impulso existencial é admissível em certos momentos de periclitação," - isto é, quando a Nação corre perigo - "que reduzem quase à unidade as opções possíveis".

Importante aqui perceber, pois terá consequências para nossa construção teórica, a ideia de que a Unidade Nacional depende de momentos especiais da vida nacional, por ele definido como de periclitação, ou seja, relativa a um momento em que a própria nação corre perigo. Poderíamos aqui ponderar sobre o fato de que a Unidade Nacional absoluta é uma abstração; mesmo nos momentos de ameaça à existência mesma da Nação, sempre haverá - ensina-nos a história das Nações - uma quinta-coluna, isto é, elementos a serviço de interesses estrangeiros.

Mas esta questão da absorção, pelas classes, dos imperativos vitais da Nação é uma original contribuição de San Tiago Dantas quanto ao debate sobre Poder Nacional. Diz ele que,

"A capacidade de captar os imperativos existenciais do Estado varia, frequentemente, entre as massas e as elites. Há momentos em que as elites se avantajam às massas, na sensibilidade àqueles imperativos (...mas também) há momentos em que as elites, deformadas por erros de educação ou por influencias estranhas, perdem aquela sensibilidade, enquanto as massas a conservam, tomando para si o papel condutor".

Por vezes as elites põem "em primeiro lugar, os interesses da própria classe, os quais podem, eventualmente, estar em contradição com os interesses da sociedade como um todo".

Isso ocorre, no caso das elites, diz Dantas, "sobretudo quando uma sociedade passa por transformações muito rápidas. As classes intelectuais, as classes dirigentes, frequentemente, atrasam-se em relação a essas transformações e mantem uma reação inadequada aos interesses vitais que já, então, se delineiam". 
Um exemplo disso, é "o descompasso entre a elite afrancesada da Russia czrista e as massas russas, na percepção dos interesses nacionais do estado invadido" por Napoleão, descrito no romance Guerra e Paz, de Tolstói. No sentido contrário, "nenhum exemplo é mais eloquente do que o da elite fundadora da independência nacional dos Estados Unidos".

Um outra notória contribuição de Dantas quanto aos elementos de Poder Nacional, diz respeito ao que ele denominou como Ideologia de uma Nação. Baseado em Marx ("A miséria da filosofia") e em Karl Mannheim ("Ideology and Utopia"), Dantas propõe retirar a acepção negativa de ideologia se essas formuladas com sentido de cumprir interesses vitais da nação. Para ele, "o espirito humano procura racionalizar o seu imperativo vital e apresenta-o como produto de um conhecimento objetivo e de um julgamento imparcial de valores, o que abre caminho para a realização de suas aspirações existenciais". Assim, "a formulação de uma ideologia, que universalize e torne racionalmente aceitáveis os imperativos existências de uma sociedade, é a missão da elite dirigente dessa sociedade e é, talvez, o que a caracteriza como elite".

O desafio de uma elite que em preservar condições de liderar a nacionalidade em relação a realização de seus desafios vitais é o que preserva sua condição de conduzir o conjunto da nacionalidade. Assim, diz Dantas, "nenhuma sociedade em expansão pode realmente alcançar a plenitude de seu ciclo evolutivo se ela não dispuser de uma classe dirigente capaz de elaborar as ideologias que tornem viáveis os seus imperativos vitais". Por tanto, sintetiza o notável chanceler brasileiro, "toda ideologia é, portanto, idealista nos seus meios e realista nos seus princípios e fins".

A justa compreensão desta disjuntiva entre idealismo e realismo que marca uma ideologia nacional, podemos dizer, marca o caráter da elites dominante e sua viabilidade em seguir como tal. Diz o autor em tela, que "por exemplo, um povo que necessita criar uma indústria doméstica, apenar de serem seus custos de produção comparativamente elevados, não se pode render culturalmente a uma ideologia livre-cambista, sem desamparar com isso os seus interesses vitais. O livre-cambismo se lhe pode impor pelos seus fundamentos racionais, mas desprotege seus interesses vitais".

Noutras palavras, não necessariamente os interesses vitais coincidem com os racionais.

Em seguida, Dantas abarcará aqueles que considera serem meios construtivos do poder nacional, os quais agrupa em um conjunto de seis elementos. Vamos a eles. 
- O elemento militar. Dantas propõe observar não somente os meios acumulados para fazer valer seus interesses vitais, mas sobretudo o poder potencial, "isto é, a capacidade que tem o Estado de refazer seu poder militar de acordo com o ritmo das necessidades das eventuais ações agressivas ou defensivas a que ele seja conduzido". Aqui, provavelmente Dantas interpreta não somente a capacidade material instalada - poder bélico, armamento -, mas a capacidade de mobilização nacional de dada sociedade. Se estivermos corretos nesta interpretação, esta não fugirá dos fundamentos do pensamento estratégico ocidental, nas visão de Clausewitz, sobre a preponderância do elemento humano.

- O elemento demográfico. Este desempenha um papel militar (fornecimento de homens para ação militar) e papel civil, "como um elemento de ocupação do próprio território e, eventualmente, de ocupação do território alheio", quando o interesse nacional assim o exigir. Para ele, a "rarefação de população representa sempre uma debilidade política, em qualquer território".

- O elemento geográfico. Trata-se das "facilidades e dificuldades criadas pela geografia física em relação a utilização do Poder Nacional".

- O elemento econômico, "pelos recursos naturais, pelos recursos tecnológicos que habilita o Estado, seja para sustentar uma economia de guerra, seja em tempos de paz para sustentar a própria economia, garantindo-lhe certa independência em relação a outros Estados". Ou seja, daqui depreende-se fatores de riqueza de um dado território ao lado de fatores que se constitui, por decisões de política de desenvolvimento.

- O elemento cultural, de "papel decisivo, já que o preparo das elites, dentro da compreensão dos seus interesses vitais e dentro da compreensão de seus interesses ideológicos capazes de recobri-los, constituem condição indispensável" para o emprego do Poder Nacional. Noutros termos, poderíamos qualificar isto que Dantas define por elemento cultural, de como as elites compreendem as potencialidade de sua própria nacionalidade, ou ainda, do grau de nacionalismo desta mesma elite.

- O elemento político, representado "por meio da ação diplomática", relativa a como os organismos internacionais "influem sobre o Poder Nacional". Um dos meios mais eficazes para a proteção do interesse nacional, é o fato de ser a "ordem internacional, toda ela imbuída multissecularmente da ideia de legitimidade. Ter a seu favor a legitimidade representa um extraordinário reforço de poder em qualquer conflito de interesses que 
possa se apresentar. A causa legitima, em primeiro lugar, impõe-se mais facilmente ao espirito dos que a sustentam, desarma o espirito dos que com ela contendem e impressiona o círculo social dos neutros, dos espectadores, dos que devem participar do conflito".

A referência de Dantas aqui, em primeiro lugar, diz respeito a impactos da normatização pactuada no sistema internacional sobre a autonomia de política nacional. Um segundo aspecto, a respeito da legitimidade de uma causa da qual se embandeira uma Nação no sistema internacional está relacionada a fatores de variadas ordens. Provavelmente o que para uma Nação, dentro de seu interesse nacional, parecer relevante a sua própria sociedade possivelmente não o será a outra, sobretudo àquela que enventualmente tenha diminuído seus poder relativo tendo em vistas perdas e ganhos líquidos de poder no sistema internacional. Por outro lado, por certo haverá causas que serão interpretadas como justas, mas estas também estão em função de percepções diferenciadas, quer por fatores culturais, quer por motivações egoístas - de qual lado for.

Enfim, na visão de Dantas, estes seis elemento são os "meios com que se fecha o sistema de proteção dos interesses vitais".

A seguir, o autor traduz esta conceituação para o caso brasileiro.

Compreende Dantas, que "as grandes dificuldades da sociedade brasileira estão todas elas relacionadas com a própria utilização de sua área, com a própria valorização dos seus recursos territoriais, naturais e demográficos". Tendo em vista até hoje, mais de seis décadas depois destas ideias terem sido expressas, todavia a apropriação das amplas potencialidades do território brasileiro ser absolutamente insuficiente, tendo em vista a realização do Poder Nacional, há que dar-se razão a esta primeira questão de Dantas.

A seguir, Dantas pontua o problema da soberania sobre o território, algo igualmente de dramática atualidade, tendo em vista a situação atual e prospectiva da política internacional, Nas palavras dele, o objetivo é "fazermos uma política externa que impeça qualquer pretensão alheia de alcançar determinação dentro de nossa própria área".

No sentido do anteriormente dito, chamava atenção, que num estado de subdesenvolvimento, diz Dantas, o país "mantém, em estado potencial, soma considerável de recursos naturais". À época da conferencia, já se manifestavam tendências que buscavam afirmar internacionalmente uma exótica doutrina do livre acesso às materiais primas, por meio de uma certa "Carta do Atlântico". Trata-se da ideia 
de que todos os países tem direito ao acesso às fontes de matérias primas e de que nenhuma sociedade pode subtrair a utilização coletiva de matérias primas que não estão sendo aproveitadas.

Trata-se de ideias que frequentemente volta a cena no cenário internacional, como por exemplo, com a exótica tese de "soberania compartilhada" sobre a Amazonia. À época, dizia Dantas, esta tese "vai ganhando, em nosso tempo, foros de ideologia. Estamos aí, diante de uma elaboração ideológica que cobre a necessidade vital para muitos países", agravada pelo fato, de que numa nação rica como a brasileira, permanecer "em estado potencial a maioria de seus recursos".

Assim, tendo em vista a conjuntura do período em que proferiu esta conferencia, alerta Dantas, temos aqui "o verdadeiro programa da sociedade brasileira: a preservação de seus recursos a longo prazo", pelo que, deve-se buscar "uma abreviação desse prazo; em outras palavras, de uma política de desenvolvimento intensivo". Em grande medida são desafios que permanecem na sociedade brasileira contemporânea.

Trata-se, argumenta o jurista, daquilo que os historiadores, seguindo "a terminologia de Toynbee, procuram denominar um desafio. Desafios são contradições de interesses que se apresentam na vida de uma comunidade e que fazem com que a comunidade se apresente, em face de um problema, em duas condições antagônicas, ou melhor, com interesses que se entrechocam, que se destroem. Toda vez que uma situação contraditória dessa natureza se delineia na vida de uma comunidade, urge encontrar aquilo que o próprio Toynbeee denomina a resposta. A resposta ao desafio, isto é, a posição ideológica, a linha de comportamento social que supere aquela contradição e permita vencer os termos críticos em que ela se acha colocada".

Assim Dantas conclui com ideia que se tornaria constante na formulação estratégica brasileira, a busca de em torno de um desafio coletivamente presente a uma dada sociedade se buscar uma resposta para equacioná-lo.

\section{A contribuição de Araújo Castro}

Por fim, cabe aqui, dentre os autores nacionais, examinar outra magistral contribuição no debate sobre Poder Nacional, por parte do embaixador Araújo Castro, proferida na Escola Superior de Guerra em 1958. 
Araújo Castro talvez tenha sido um dos mais "geopolíticos" dos chanceleres brasileiros. Marcou sua curta passagem pela Casa de Rio Branco, entre 1963 e 1964, como firme defensor da maior presença internacional do Brasil, visando aumentar sua autonomia nacional. Como chanceler, pronuncia nas Nações Unidas o chamado discurso dos três Ds - Desarmamento, Desenvolvimento, Descolonização (1963) -, que constitui peça emblemática não apenas da história diplomática brasileira, mas da própria história de um período das relações internacionais marcado pela disjuntiva Norte-Sul.

Este celebre discurso guarda uma importante lição sobre alianças "de geometria variável" no sistema internacional (para usar uma expressão de outro notável ex-chanceler brasileiro, Celso Amorim). Diz Castro,

\begin{abstract}
"Assistimos no mundo contemporâneo e nas Nações Unidas à emergência não de blocos neutros ou não-alinhados, ou de uma terceira força política ou ideológica, mas de afinidades - afinidades talvez menos estáveis, porém mais atuantes em termos de objetivos táticos, configurando base de reinvindicações comuns (...) numa luta continuada em torno de três temas fundamentais: Desarmamento, Desenvolvimento Econômico e Descolonização".
\end{abstract}

Aqui, busca o embaixador brasileiro caracterizar a emergência de um novo bloco no sistema internacional então cindido ideologicamente pela guerra fria, em uma aliança por afinidades, tendo em vista objetivos reformistas em relação ao status quo mantido pelas duas grandes superpotências.

Retornemos agora a conferência de Araújo Castro na na ESG. Sua fala sobre Poder Nacional é tido como uma de suas mais destacadas contribuições a formulação do pensamento diplomático brasileiro. Esta conferência, como diz estudo sobre seu pensamento ${ }^{5}$, "deixa clara a influência sobre Castro da 'escola realista' das Relações Internacionais. Citando Maquiavel e Morgenthau, entre outros, Castro reitera a inescapável realidade e centralidade da política do poder" (COSTAS VARGAS, 2013, P. 48).

Examinemos a apresentação sobre Poder Nacional proferida em 1958, na ESG, a partir de quatro elementos.

Araújo Castro parte da análise do que ele chamou de "limitações de ordem interna" para a consecução do Poder Nacional.

\footnotetext{
5 "Um mundo que também é nosso. O pensamento e a trajetória diplomática de Araújo Castro", de João Augusto Costas Vargas. Funag, 2013.
} 
A primeira questão é a Terra. A base física (território), é elemento mais estável e permanente que determina o poder de uma Nação.

No entanto, antecipando uma visão que hoje torna-se realidade, com os BRICS como atores chave do sistema internacional, Araújo Castro (1982, p.6) observa que "existem indícios seguros que estamos na época dos países-massa: Estados Unidos, Rússia, China, Brasil, Índia, Canadá, etc. Os progressos da técnica e o advento de novas formas de energia vieram permitir uma infinitamente melhor utilização de recursos naturais que, pela lei das probabilidades, mais facilmente se encontram em países de grande massa territorial". A ideia das força dos "países-massa", numa conferência que ano próximo completará seis décadas, parte portanto de uma base objetiva - "lei das probabilidades" - para antecipar um fenômeno real das Relações Internacionais.

Recursos naturais. Em primeiro lugar, a questão dos alimentos. "Uma situação mais ou menos permanente, de escassez de produtos alimentícios constitui uma grave vulnerabilidade do poder nacional de um Estado", diz Castro. Naquele momento, vale dizer, o Brasil todavia era dependente da importação de alimentos. O Cerrado brasileiro, por exemplo, hoje um grande celeiro do mundo, todavia não era apto para produção agrícola devido a acidez da terra - fator corrigido posteriormente com a intervenção cientifica a partir das pesquisas da Embrapa.

Na mesma chave dos recursos, dizia o embaixador, "desnecessário nos parece acentuar a importância do Petróleo, fator que determina quase toda a política das grandes potencias na área do Oriente Médio". Castro lembra que na primeira guerra, Clemenceu dizia que uma gota de petróleo bem valia uma gota de sangue de um soldado francês.

$\mathrm{Na}$ chave dos recursos, comparece o problema do desenvolvimento da Industria. "O poder nacional de um Estado é hoje determinado, de maneira preponderante e talvez de maneira decisiva, pela sua capacidade industrial (...). Para o Brasil, o caminho mais rápido, mais direto para o fortalecimento de seu Poder Nacional é o próprio caminho do seu desenvolvimento econômico e expansão industrial". Para isso precisamos, dizia o embaixador, "queimar etapas em nossa evolução. Não estamos necessariamente condenados a percorrer todos os estágios do desenvolvimento percorrido por países que se adiantaram a nós na economia e na indústria; a ciência e a tecnologia, aplicadas com imaginação e com audácia, na utilização de nossos recursos naturais, poderão levar-nos, num futuro próximo, a uma posição de força no cenário internacional” (1982, p.8-9). 
A terceira chave refere-se ao Homem. "Os países que hoje detém o poder mundial são todos países que ocupam lugar de primeiríssimo plano nos quadros demonstrativos de população", isto é, no fator demográfico. "Esparta morreu por falta de gente (...) Mussolini desencorajou a emigração italiana e favorecia a concessão de benefícios e compensações às famílias de prole numerosa. O declínio do poder francês na Europa, poderia, por outro lado, ser explicado por contingencias ligadas ao enfraquecimento demográfico". Num momento em que o problema demográfico se acentual no Brasil, tal advertência soa atualíssima.

Quanto às Instituições. "As instituições (família, escola, trabalho, religião, governo, Estado) de cada Estado terão que ser examinadas cuidadosamente se quisermos proceder a uma avaliação judiciosa do Poder nacional de um determinado país". O embaixador observa que a União Soviética "caminhou de sua economia rudimentar de 1917 para uma estrutura econômico- industrial que a coloca em posição de desafiar a posição americana". Para ele, as características das instituições soviéticas, "tende a dar uma consistência monolítica às atividades do Estado soviético em nível operacional”. Castro aqui apresenta uma questão relevante do ponto de vista do modelo político mais adequado ao adensamento do Poder Nacional. Se um Estado forte e centralizado, com maior unidade de propósitos em torno de seus objetivos ou se um sistema democrático e plural, mas com menor coesão e capacidade de implementar desígnios estratégicos. Castro faz uma opção pelo segundo, a despeito das limitações mais acentuadas ao adensamento do Poder Nacional.

Adiante, Castro lembra que "George Kennan, o teorista da política de containment, tem procurado rebelar-se contra o moralismo latente em um determinado tipo de política exterior a cargo do Departamento de Estado". Aqui, numa consideração sobre ética e poder, diz Castro que "num mundo dominado pelo conceito de poder, não podemos considerar necessariamente imoral qualquer tentativa de fortalecimento e acréscimo deste Poder". Afinal, diferente do indivíduo, os Estados tem maior margem de manobra moral, uma vez que prepondera para estes seu próprio interesse nacional.

A seguir, o embaixador se referirá às limitações de ordem externa.

Para ele, "o Poder Nacional, determina os limites úteis da política externa de um determinado país (...) Cada Estado poderá ter apenas um voto nas grandes Assembleias internacionais, mas atrás de cada Delegado estão idealmente representadas as Forças 
armadas, as alianças, os recursos econômicos, naturais e tecnológicos de cada país". Trata-se aqui de um importante conceito a desconstruir a visão idealista ou idílica sobre o funcionamento do Poder Mundial, baseado em força derivada do Poder Nacional de cada Estado que o compõe.

Recorrendo a Morgentheu, argumenta o embaixador que a Diplomacia é o cérebro do Poder nacional, pois consiste precisamente na arte da mobilização de todos os elementos integrantes deste Poder, dirigidos para os setores da vida internacional que se relacionam mais diretamente com os interesses nacionais. Aqui, podemos observar que esta mobilização pela Diplomacia ocorre em tempos de paz; em tempos de guerra, essa mobilização dos elementos do Poder nacional visando a vitória recai sobre o poder militar.

Não obstante ser crucial não ter maior ilusão quanto às Instituições Internacionais, nem mesmo o mais convicto do geopolítico desconsiderará esta assertiva de castro, que observa que "os compromissos internacionais, as alianças e acordos constituem evidentemente limitações de soberania e limitações de autonomia da vontade dos Estados". Assim, “o Poder é um conceito relativo; somente pode ser considerado, no campo externo, em correlação ao Poder efetivo de que dispõe os outros Estados”. Poder Nacional se constrói ou retrocede: "nenhum poder é eterno ou imutável” (1982, p.22).

Não poderíamos concluir o resgate do embaixador geopolítico, sem nos debruçarmos sobre outro celebre conferencia de Araújo Castro, agora representante brasileiro nas Nações Unidas, novamente na Escola Superior de Guerra (ESG), em 1971, denominado "o congelamento do Poder Mundial".

Castro inicia advogando pela necessidade do país definir uma "norma de conduta brasileira no âmbito da comunidade das nações”, isto é, da política internacional, Esta difere da tradição, já consolidada, segundo o embaixador, quanto à política externa. A primeira, interpretamos, refere-se às relações de poder entre os Estados no sistema internacional. Política externa, por sua vez, se referirá ao campo mais estrito das relações internacionais do país com outros Estados nacionais.

A importância de definição de uma norma de conduta decorre do fato de que há, na interpretação de Araújo Castro, "firme e indisfarçada tendência no sentido de congelamento do poder mundial. E quando falamos de poder, não falamos apenas de poder militar, mas também de poder político, poder econômico, poder cientifico e 
tecnológico. O Tratado de Não-Proliferação, ponto mais alto da détente entre a URSS e os Estados Unidos, é o instrumento central desta política de congelamento do poder mundial". Central pois o Tratado "estabelece distinta categorias de nações (...) estende ao campo da ciência e da tecnologia privilégios e prerrogativas”. Assim, diz ele, “'Desarmar os países já desarmados' - esse parece ser o lema e o programa do Comitê" (de desarmamento). Noutra chave, igualmente securitária, há também, "frequentes tentativas para disciplinar o fluxo de armas convencionais para os países subdesenvolvidos, sob a alegação que este fluxo constitui um novo obstáculo às tarefas de desenvolvimento econômico" (1982, p.200-201)

Outro tema é o do comercio internacional. Diz Castro que as grandes potencias, se opõe "tenazmente aos esforços dos países em desenvolvimento no sentido de modificar as normas que ainda regulam o comercio internacional". Quem observar as discussões no âmbito da OMC, desde que esta se constituiu, verá a atualidade dessa ideia.

A seguir, antecipa problema então embrionário, mas hoje bastante presente, a questão ambiental, nos seus primeirdio de utilização geopolítica comom instrumento de congelamento do Poder Mundial. Segundo Araújo Castro, algumas tendências que se "manifestam no tratamento dos problemas de população e preservação do meio humano (environment)”, na qual “(...) alguns Estados, como por exemplo, o Brasil, não obstante seus noventa e cinco milhões de habitantes, estão a requerer um crescimento demográfico em consonância com as necessidades de pleno aproveitamento de seus recursos naturais e da efetiva ocupação do seu território" em contraste com as aspirações preservacionistas das grandes potências de então. Atualmente, a sofisticação do uso de questões ambientais como instrumento de congelamento de Poder é muito mais intensa, como se vê na pressão dos países centrais para que o Brasil mantenha preservadas (ou congeladas?) vastas áreas indígenas sobrepostas a vultosos recursos minerais em seu subsolo.

A manobra ambiental, então em seus primórdios, voltava-se também contra a Industrialização. Diz Araújo Castro que na questão "da preservação do meio humano, tende-se a colocar uma tônica demasiado forte nos perigos da rápida industrialização. Acentua-se os perigos da poluição, certamente grave para os países altamente industrializados, quando a maior parcela do planeta ainda vive num estágio de précontaminação ou, em outras palavras, ainda não teve a oportunidade de ser poluída”. 
O embaixador brasileiro denuncia ainda que as grandes potencias buscam "despolitizar" as Nações Unidas e introduzem as “chamadas 'novas tarefas' (não-proliferação, controle da poluição, narcóticos, meio humano et coetera)". Qualquer semelhança com o debate estratégico - securitário de nossos dias não será mera coincidência.

Araújo Castro também demonstra na conferência que a aspiração do Brasil em jogar um papel global vem de longe, não é fato novo resultado de suposto voluntarismo na presidência de Lula (2003-2010). Lembra ele que o Brasil, em abril de 1970, propôs ao secretário geral da ONU um processo de "reativação diplomática da ONU”. “(...) propôs que um desses comitês fosse imediatamente estabelecido para explorar as modalidades de uma solução pacifica aos problemas do Oriente Médio. Árabes e judeus acolheram, de maneira afirmativa, a sugestão brasileira, que, entretanto, foi, até agora, recebida com frieza pelas grandes potencias”. Qualquer semelhança com o episódio de 2010, conhecido como Acordo de Teera ${ }^{6}$, tampouco será coincidência.

A seguir Araújo Castro reporta outra ação de congelamento em tema caro ao Brasil, devido a sua geografia. Nossa soberania marítima então era fortemente posta em questão devido ao não reconhecimento plena da soberania sobre o mar territorial. Diz o embaixador, que "nos assuntos relativos ao Direito do Mar (...) as grandes potencias marítimas se opõem tenazmente à fixação de limite para o mar territorial que exceda o número, perfeitamente arbitrário, de doze milhas (...) à base do princípio de liberdade dos mares, em 'benefício comum da humanidade"”. Por outro lado, diz ele, "é interessante, entretanto, observar que, já no que toca à utilização e exploração dos recursos dos fundos marinhos, as grandes potencias se revelam muito mais refratárias a aceitar a tese do "patrimônio comum da humanidade", tendo em vista serem detentoras do monopólio da tecnologia adequada para a exploração.

Após apresentar estas ativas políticas de congelamento do poder mundial - às quais, podemos dizer, todas ainda vigentes, algumas intensificadas e novos introduzidas -, Araújo Castro observa que a política internacional do Brasil "tem como objetivo remover quaisquer obstáculos que possam oferecer-se contra o seu pleno desenvolvimento econômico, tecnológico e cientifico, contra a preservação de suas herança cultural e de sua identidade nacional, como país soberano, e contra a afirmação e crescimento de seu poder nacional'. Aqui há uma importante conceituação sobre, digamos, os objetivos mais

\footnotetext{
${ }^{6}$ kdsjhjhldfsljfhDSFJGFHdfhDJFDjfdj
} 
vitais da política externa de um país como o Brasil: a remoção de entraves ao seu desenvolvimento - conceituação de dramática atualidade no mundo de hoje. Noutra palavras, do próprio Araújo Castro, “a política internacional do Brasil tem como objetivo primordial a neutralização de todos os fatores externo que possam contribuir para limitar o seu Poder Nacional” (1982, p.212).

Por fim, cabe ainda resgatar uma observação de Araújo Castro sobre o comportamento norte-americano de então. Referindo-se à política externa de Nixon, "baseada nas ideias do professor Kissinger" - de reconhecida inspiração geopolítica e realista -, "seria fora de propósito falar de uma tendência isolacionista. Dever-se-ia, antes, falar de realismo, de pragmatismo, da fria consideração dos interesses americanos". Sob a presidência de Donald Trump, os Estados Unidos de nossos dias, igualmente, seguem orientação semelhante a esta referida por Araújo Castro. Inclusive na ação tática quanto aos embates nas relações internacionais contemporâneas. Diz o embaixador que "o mais provável é que tenhamos períodos cíclicos de negociação e de confrontação, ou mesmo, uma fase indefinida de simultaneidade entre confrontação e negociação". Cinco décadas depois, é a forma que opera a política externa de Trump.

c) Contribuição de autores internacionais

\section{A contribuição de Morgenthau}

Segundo conhecido dicionário de relações internacional" ${ }^{7}$, Hans J. Morgenthau "foi chamado de 'O Papa' das relações internacionais. Ele é, certamente, o mais conhecido dos pensadores clássicos e realistas do século XX” (2004, p.61). Sua grande contribuição é a obra "A Política entra as Nações - A luta pelo Poder e pela Paz", originalmente publicada em 1948.

Para Ronaldo Mota Sardenberg, autor do prefácio a Política entre as Nações, "A essência do seu pensamento está em uma difícil composição entre as considerações de Poder - a própria conceituação do realismo político, suas formas, dimensões nacionais e balança de

\footnotetext{
${ }^{7} 50$ grandes estrategistas das relações internacionais. Martin Griffiths, Editora Contexto, 2004.
} 
poder - e a visão das limitações ao Poder nacional, expressas em termos de moral, opinião pública, direito internacional, paz, organização internacional e diplomacia" (2003, p.XX).

Este autor é fundamental, tendo em vista os objetivos do presente trabalho, em duas dimensões que apresentaremos e discutiremos a seguir. A primeira mais estritamente sobre aqueles que constituem os elementos do poder nacional (capitulo IX). A segunda, que discutiremos em seguida, versará sobre sua teoria de poder e de equilíbrio no sistema internacional.

Em primeiro lugar, é importante observar que para Morgenthau, quanto ao Poder Nacional, há que diferenciar os elementos relativamente estáveis daqueles sujeitos a constante modificações. Dito isso, para Morgenthau, são elementos constitutivos de Poder Nacional:

- Geografia (A terra), "o mais estável dos fatores". Aqui, seguindo princípio das geopolítica, Morgenthau concordará que toda a análise da política de poder de um dado país partirá de sua condição geográfica.

A condição geográfica permaneceria central, mesmo como o desenvolvimento técnico dos transportes, das comunicações e dos armamentos, pois este não eliminou completamente "o fator insulante dos oceanos", ainda que este fator seja menos significativo que antes. No caso dos EUA, argumenta, a distância da Europa e da Ásia é fator fundamental - lembrando que a obra é de 1948, pouco depois da segunda guerra mundial, na qual o relativo isolamento do território norte-americano foi fator chave para este país. Se referindo a União Soviética - em algo que continua valido para a Rússia -, diz que a extensão territorial sempre constituiu fator de prestigio e até o momento frustrou todas as tentativas de conquistas militares vindas de fora. Por outro lado, as longas planícies da Alemanha e Polônia constituem desvantagem, seja para Europa ou para a Rússia. Já a Grã-Bretanha com o Canal da Mancha, a Itália com os Alpes ou a Espanha com os Pirineus, possuem vantagens geografias importantes, como já visto no passado, argumenta.

No caso brasileiro, como dissemos anteriormente, nossa dupla condição de relativo afastamento das zonas de tensão geoestratégica contemporânea, por um lado, e o fato de nossa condição de desenvolvimento impar em nosso entorno estratégico, é condição a valorizar no pensamento estratégico. 
- Os recursos naturais. Fator relativamente estável e afeito ao território, é dividido por Morgenthau em três aspectos: alimentar, das matérias primas e do petróleo.

- Alimentos, "o mais elementar destes recursos", pois um país que seja autossuficiente já conta com uma grande vantagem inicial. A Grã-Bretanha, que antes da $2^{\text {a }}$ Guerra só produzia $30 \%$ de seus alimentos, sempre dependeram de sua capacidade de manter aberta ao trafego as rotas marítimas. Sempre que sua capacidade de importar alimentos esteve ameaçada, o próprio poder britânico esteve sob ameaça. Não por acaso, historicamente, a propensão britânica ao mar - magistralmente analisada por Alfred Mahan $^{8}$ - faz todo o sentido. No caso da Alemanha, na $2^{\text {a }}$ guerra, o bloqueio aliado, ao impor privações ao povo alemão, constituiu um dos fatores essenciais para a vitória aliada. Diz Morgenthau, que "a autossuficiência em alimentos, ou a carência dos mesmos, constitui um elementos relativamente estável na formação do poder nacional, embora, por vezes, possa estar sujeito a mudanças decisivas, como nos mostra o caso da Índia". Observasse a revolução no campo brasileiro realizada nos anos 1970, o autor certamente teria um exemplo ainda mais contundente de criação de uma potencial agrícola como é o caso brasileiro.

- Quanto às matérias-primas, trata-se de recursos naturais fundamentais a produção industrial e mesmo para a condução de uma guerra. Com a Revolução Industrial e a mecanização do esforço bélico, as matérias primas passam a ter papel chave para o Poder Nacional. Quem observa atualmente o esforço chinês - a maior economia do mundo, mas relativamente pobre em termos de matéria-prima - em garantir fluxo estável de matérias-primas para sustentar sua capacidade industrial, verá a grande atualidade dessa questão levantada por Morgenthau. Por outro lado, a influência de determinadas materiais primas variam com o tempo. É o caso do Urânio, que passa a ter enorme preponderância moderna, dizia em 1948 nosso autor em tela. Hoje poderíamos falar das terras-raras, do lítio ou do nióbio - este último, por exemplo, tem quase a totalidade de sua produção mundial extraída do Brasil.

- Por fim, quanto aos recursos naturais, Morgenthau fala do poder do petróleo, “desde a $1^{a}$ guerra”. O surgimento do petróleo como matéria prima indispensável provocou uma mudança no grau de poder relativo dos países politicamente mais poderosos. União Soviética, autossuficiente, tornou-se ainda mais poderosa, enquanto o

\footnotetext{
${ }^{8}$ Sobre a Teoria do Poder Naval de Mahan, ver CARMONA, 2012.
} 
Japão se enfraqueceu. Assim, “se, por qualquer motivo, os países produtores de petróleo decidirem impor um embargo total ao Japão, eles podem destruir seu tecido político, econômico e social". Se ao embargo associarem exigências políticas, forçaram o país a aceitar tais condições independente de sua vontade. Este exemplo demostra o elevado grau de barganha que o Brasil pode exercer, tendo em vista suas elevadas reservas de petróleo dos depósitos do pré-sal, se tiver consciência da potencialidade do uso do fator petróleo como instrumento de poder.

O controle dos campos do Oriente Médio tem constituído fator de poder, observa Morgenthau. Os impactos do embargo às exportações de petróleo no inverno de 1973-74, com a elevação drástica do preço teve impacto dramático: “elas passaram a poder aplicar uma espécie de torniquete nas nações consumidoras". Já o controle do preço pode ter fator determinante sobre a estabilidade da economia mundial e da inflação. A citada crise de 1973-74 e mais recentemente, o movimento geopolítico dos Estados Unidos (com a promoção da extração por fracking) em combinação com as petro-monarquias sunitas do Golfo, derrubaram o preço do petróleo no mundo, impondo fortes limitações a inimigos como a Russia e a Venezuela, e junto com isso, ameaçando a viabilidade da província brasileira do pré-sal.

Países tentam mitigar dependência, como fez os EUA com o desenvolvimento do projeto Manhattan, para o desenvolvimento da fissão nuclear como fonte alternativa de energia, observado Morgenthau, ou, mais recentemente, como o duvidoso caso de extração por fraking.

- Após falar da geografia e dos recursos naturais, Morgenthau acorda a questão da capacidade industrial. Para ele, a posse de recursos naturais não necessariamente transforma o país numa potência, pois ela dependerá da existência de instalações industriais capaz de utilizar estas capacidades. Por isso, podemos dizer, países ricos em recursos naturais facilmente podem se converter tão somente em colônias extrativistas e continuar pobre e com escasso Poder nacional. O autor argumenta que EUA e URSS tinham, na posse de carvão e ferro ao lado de estabelecimentos fabris capazes de transformar aquelas jazidas nos mais variados produtos industriais. Sem instalações industriais, a URSS não poderia ter estabelecido um complexo militar compatível com sua política externa. A Índia, por sua vez, igualmente rica em carvão e minério de ferro, além de manganês, padecia pelo "fosso entre as potencialidades e as realidades de poder", por sua escassa capacidade industrial Por muito tempo, a Grã-Bretanha foi a única 
potência mundial pelo fato não concorrentes na capacidade industrial. A União Soviética só passou a figurar entre as potencias a partir da industrialização dos anos 30 .

Da mesma forma, destaca-se a capacidade tecnológica - ligada a capacidade industrial como fator preponderante para a condição de potência. Observando tendências contemporâneas relativas a manufatura avançada ou Industria 4.0, levada a cabo pelas nações mais desenvolvidas, daremos razão a centralidade do desenvolvimento tecnológico associado ao desenvolvimento industrial.

- A preparação militar. Essencialmente, "o poder nacional, depende do grau de preparação militar", capaz de apoiar a política externa. Ou seja, não há política externa poderosa num país desprovido de um poderoso porrete. Aqui, quando a preparação militar, Morgenthau divide-a em três chaves. Vejamos.

- As inovações tecnológicas. O destino de muitas Nações e civilizações, historicamente, "é frequentemente determinado por um diferencial na tecnologia das artes bélicas que o lado perdedor não foi capaz de compensar por outros meios". Surgimento da infantaria, das armas de fogo e da artilharia às armas tradicionais dos séculos XIV e XV "significou uma momentosa mudanças na distribuição de poder em beneficio daqueles que usaram essas armas antes que os inimigos o fizessem”. Mesmo o fim de uma era da civilização - no caso, o fim da Idade Média e o início da Idade Moderna -, ocorreu após a derrota dos senhores feudais que seguiam confiando em suas cavalarias e Castelos, até então eficazes. O século XX assistiu quatro inovações importantes na técnica de fazer a guerra: o submarino, que começo a ser empregado pela Alemanha na primeira guerra; o tanque, utilizado em quantidade considerável pelos britânicos no final da primeira guerra; "a coordenação estratégica e tática da força aérea com as tropas de terra e mar" como determinantes para a superioridade nipo-germânica no início da segunda guerra mundial; finalmente, o aparecimento das armas nucleares e os meios para as lançar.

Cabe ressaltar aqui a importância transcendental da existência de uma pujante e desenvolvida Base Industrial de Defesa (BID), como condição de potência. Não apenas pelo extraordinário papel para obter inovações capazes de se traduzir em superioridade estratégica, como pelo papel econômico mais amplo da Industria de Defesa, dado seu papel de transbordamento e difusão de inovações por toda a Indústria. 
- a qualidade da liderança militar. Morgenthau fala do "gênio militar" de Frederico, o Grande, para as vitorias da Prússia; sucedido pela liderança de Napoleão a frente da França que viria a destruir a própria Prússia, fruto de alterações na arte da guerra. Outro exemplo é o diferente comportamento do Estado Maior francês e alemão na segunda guerra. Enquanto os franceses, com sua "Linha Maginot", continuavam raciocinando nos termos da primeira guerra, subestimando as probabilidades de uma guerra de movimento derivada dos avanços da tecnologia moderna, os alemães planejaram suas campanhas em função de uma mobilidade até então sem precedentes, com a blitzkrieg da divisões panzer hitleristas e pelos bombardeios de mergulho sobre a cavalaria inimiga. Assim, o papel da liderança militar em planejar na sua acepção última do desenvolvimento da arte da guerra, se torna questão chave, ainda mais na Era atual, de intensificação do progresso tecno-científico.

- Por fim, quanto ao Poder Miliar, Morgenthau fala da quantidade e qualidade das Forças Armadas. Para o autor, "o poder de uma nação em termos militares depende também da quantidade de homens e armas disponíveis e de sua distribuição entre os diversos ramos do estabelecimento militar”. Os avanços tecnológicos da guerra moderna, não levam, em absoluto, ao desprezo do elemento humano como chave para a vitória estratégica. Se é correto dizer que na Era atual, não mais se depende de contingentes desproporcional de homens nas Forças Armadas, é correto analisar, por um lado, a centralidade do engajamento do povo do país num contenda, e por outro lado, dar razão a Morgnthau quanto a qualidade desse efetivo militar.

- A população (o Homem). Aqui, há duas chaves a analisar.

- Primeiro, a distribuição. Para o autor, não necessariamente o poder de uma nação será maior quanto maior for o número de seus habitantes, mas "nenhum país pode se tornar ou permanecer uma potência de primeira grandeza, caso ele não pertença ao grupo de nações mais populosas do globo". Afinal, sem população números não se mantém ativa uma poderosa planta industrial, nem se põe em campo numerosa tropa de combate ou há pessoal para suprir estas tropas de alimentos. Esta é a razão pela qual "países imperialistas incentivaram o crescimento populacional como todos os tipos de estímulos". Países com grandes territórios, como Austrália e Canadá, tem a demografia limitante de seu poder nacional. Por outro lado, populações muitos extensas em nações subdesenvolvidas - cita o caso da Índia e do Egito - podem constituir-se em fator de diminuição do poder 
nacional, uma vez que para fazer frente a fome e a escassez, recursos que potencialmente poderiam aportar a seu fortalecimento são desviados para fins de subsistência.

- tendências populacionais. Um declínio considerável da massa de trabalho de uma nação relativamente a seus rivais, constitui um declínio do poder nacional, ao passo que uma elevação significativa, sob condições similares, corresponde a ganho de força nacional. Da mesma forma, fator a considerar é a distribuição etária desta população, tendo em vista ser passível de utilização para fins militares ou produtivos.

A análise das tendências demográficas no mundo trazem reflexões a respeito do afirmado do Morgenthau. Por toda a Europa, Rússia incluída, há forte tendência a um declínio de população. Mesmo o Brasil - e esse é um tema central do projeto nacional - há uma tendência demográfica preocupante. Por outro lado, a Índia e as populações muçulmanas em geral, apresentam fortes tendências a incrementar-se. São temas candentes do pensamento estratégico.

$* * *$

A seguir, o autor aborda quatro aspectos de caráter subjetivos, para ele, "qualitativo", relacionados a existência do Poder Nacional. Vamos apresenta-los a seguir de forma sucinta.

- A Índole Nacional. Se propõe discutir a questão não com os fatores que a desenvolve, mas com sua existência no sentido antropológico de um "padrão de cultura". A discussão proposta aqui, como fonte de Poder Nacional, é em que medida, "traços fundamentais intelectuais e morais" conferem a cada Nação sua originalidade inconfundível. Em nossas palavras, como a formação social de um povo impacta na sua condição de agregar ou desagregar Poder Nacional.

O individualismo britânico, expresso, por exemplo, em Locke ou Burke, do mesmo modo que em sua carta magna ou no sectarismo protestante; a tradição filosófica alemã, expressa em Kant e Hegel, sua "tradição de governo autocrático", por sua vez, são reveladoras de uma característica alemã. O academicismo, ao lado de sua tradição jacobina e a filosofia de Decartes ou Volteire caracterizam-se como traços gauleses; ou ainda o pragmatismo americano, seu idealismo dogmático, descrito por Toqueville em Democracia na América. Já os russos, teriam como uma característica principal a "força e a persistência elementares" - como observou Bismarck, ao notar o comportamento de 
um soldado, nas enchentes de São Petersburgo de 1825, que ao não ser dispensado, morreu afogado.

Assim, para Morgenthau, "a índole nacional não pode deixar de ter impacto sobre o Poder Nacional. Todos os que, na guerra e na paz, agem em nome da Nação (...) trazem consigo, em um maior ou menor grau, a marca destas qualidades intelectuais e morais que integram a índole nacional". Assim, prossegue o autor, para observar "a força relativa de diferentes Nações terá de levar em consideração as índoles nacionais respectivas, por mais difícil que seja a tarefa de estimar corretamente um fator tão fugidio e intangível".

Da subestimação de importância destes traços para o Poder Nacional, está a minimização do esforço de recuperação da Alemanha após a primeira guerra ou da capacidade russa em resistir no período 1941-42. O Tratado de Versalhes poderia restringir a Alemanha todos os outros componentes materiais do poder nacional, mas não poderia privar aquele país de suas capacidades de intelecto e caráter.

- Um segundo elemento é o de natureza moral (espírito) nacional, isto é, "o grau de determinação com que uma nação apoia as políticas externas de seu governo na guerra ou na paz".

Diz o autor, que "sob a forma de opinião pública, ela proporciona fator intangível, sem cujo apoio nenhum governo, democrático ou autocrático, seria capaz de implementar suas políticas". Sua presença ou ausência, bem como suas qualidades, são reveladas de modo particular em épocas de crise nacional, quando a existência da nação está em jogo". O moral de um povo pode entrar em colapso em condições extremas, durante as quais há uma imprevisibilidades de tais reações coletivas.

Para o autor, "qualquer país dominado por divisões de classes profundas e insuperáveis terá o seu moral nacional em estado precário". Ou seja, poderíamos denominar como coesão nacional o fator chave relacionado ao Poder Nacional aqui apresentado.

A seguir, Morgenthau dá um passo adiante e diz que "em última análise, portanto, o poder de uma Nação tendo em vista o seu moral nacional, reside na qualidade de seu governo", ou, em nossas palavras, do grau de comprometimento de um dado governo com os interesses nacionais mais vitais e genuínos.

Assim, "um governo que se mostre capaz de traduzir as convicções e aspirações inarticuladas de seu povo em objetivos e políticas internacionais" - e, agregamos, 
nacionais - "contará com as melhores probabilidades de canalizar as energias nacionais em apoio aos referidos objetivos e políticas". Para ele, a qualidade do governo é o único fator tangível do moral nacional, sem a qual, o Poder Nacional "nada mais é que uma força material". Assim, a moral constituiria "a alma" do poder nacional.

- Sobre a qualidade da política externa. "Para a realização do poder nacional em tempos de paz, a condução das questões internacionais por seus diplomatas corresponde, à execução da estratégia e da tática militar por seus chefes militares, para fins de assegurar o Poder Nacional em tempos de guerra. Trata-se, nos dois casos, de reunir os diferentes elementos de Poder Nacional, no intuito de fazer com que produzam o maior efeito possível (...) aos interesses nacionais". A diplomacia seria o "cérebro" do poder nacional, cuja qualidade, exercerá, como se viu ao longo da história, papel catalizador dos fatores de poder nacional.

\section{- A qualidade do Governo.}

Para Morgenthau, a qualidade de um governo corresponde aos três fatores a seguir:

- o equilíbrio entre recursos materiais e humanos e a política externa. A seleção dos objetivos e métodos de uma política externa é realizado tendo em vista o poder disponível. Ou seja, em geral, a capacidade de um dado país tornar, via política externa, as condições internacionais mais favoráveis ao seu interesse nacional está em função de quanto poder material - inclusive o militar - de que ela dispõe.

Assim, ensina Morgenthau, não se deve fixar o alvo num nível demasiado baixo - como fizeram, exemplifica, os EUA entre as duas guerras mundiais -, nem deve "estabelecer sua mirada num nível alto demais", que não poderá ser executada tendo em vista o poder disponível - como fizeram, segundo o autor, os EUA nas negociações de paz de 1919, quando se comportaram, citando Lloyd George, "como guardiões exclusivo dos dez mandamentos e do sermão da montanha”. Assim, o Poder Nacional disponível determina os limites da política externa.

- o equilíbrio entre recursos disponíveis. Diz o autor que "nenhuma nação atinge necessariamente o máximo de Poder Nacional pela simples razão de ser rica em recursos naturais, por possuir população numerosa, ou porque tenha construído uma enorme capacidade industrial ou militar. Ela alcançará esse nível máximo quando tiver à sua 
disposição, em quantidade e qualidade suficientes, e nas proporções corretas, aqueles recursos de poder".

- Por fim, um terceiro fator que demonstra a qualidade do governo é o apoio popular a política exterior a ser executada. Trata-se “da missão mais difícil de todas (...) que o governo obtenha a aprovação de seu próprio povo para as suas políticas internas e externas destinadas a mobilizar os elementos de poder nacional em favor das mesmas". Contudo, não é suficiente. "É também indispensável que ele angarie o apoio da opinião pública de outras nações em favor de suas políticas domesticas"; afinal, diz o autor, "a política externa dos nossos dias está sendo exercida não somente com a ajuda das armas tradicionais da diplomacia e do poder militar, mas também com a nova arma da propaganda (...) a uma disputa pelas mentes dos homens”. Aqui, Morgenthau poderia ainda referir-se, caso existisse o conceito em 1948, a ideia do soft-power de uma Nação, como elemento chave de sua projeção de poder.

\title{
O conceito de potência
}

Neste trabalho, buscamos contribuir para a atualização do projeto brasileiro de potência, como se diz no título da Tese. Cabe, portanto, percorrer brevemente o conceito de potência. Nos apoiaremos para isto em duas contribuições: uma já clássica, do General Meira Mattos e outra mais recente, do Prof. Ângelo Del Vecchio?.

Del Vecchio pergunta: "existe uma teoria de potência?".

Para ele,

\begin{abstract}
“A potência dos Estados é um atributo com sujeito e âmbito de realização específicos. Evidentemente, este sujeito é o próprio Estado, que adquire particular materialidade quando desenvolve seu protagonismo frente a outros Estados autônomo, num sistema de atores (Estados) caracterizado pela ausência de normas capazes de constranger as ações destes mesmos atores. Em outras palavras: como prega a visão realista, no sistema de Estados reina a anarquia. Assim, a potência de um Estado constitui-se mediante atos cuja natureza é total e unívoca e cuja repercussão dá-se principalmente no interior deste sistema interestatal" (2010, p.21).
\end{abstract}

\footnotetext{
9 Ver MEIRA MATTOS, Carlos. Brasil, Geopolítica e Destino. Livraria José Olympio Editora, Rio de Janeiro, 1975. Capítulo VI, "Conceito de Potência Mundial", p. 69-73 e DEL VECCHIO, Ângelo (org.). Política Internacional e Hegemonia - Brasil e Estados Unidos no contexto da globalização. Editora Sociologia e Política, São Paulo, 2010. Capitulo I, "Notas sobre o conceito de potência", p.21-38.
} 
Assim, segundo Del Vecchio, "Maquiavel inaugura, pois, a doutrina da razão de Estado, cujo núcleo conceitual caracteriza-se pela tendência inexorável do continuo incremento e da consolidação da potência do Estado, acima de qualquer outro fim, tornando-se as demais dimensões da política função deste imperativo" (2010, p. 26).

Com base na leitura e na visão realista, que desenvolveremos no próximo capítulo, portanto, podemos situar o desafio relacionado a condição de potência com um atributo próprio da presença de uma das unidades de um ambiente anárquico, que almeja adensar seus atributos de poder no sistema internacional.

Cabe agora fazer uma revisão de como autores clássicos do pensamento estratégico concebem atributos de potência, na síntese de Meira Mattos.

Rodolf Kjéllen, considerado o fundador da Geopolítica, estabeleceu três atributos como características de uma grande potência: espaço, liberdade de movimento e coesão interna.

Por espaço, define-se a dimensão geográfica, sendo o Brasil, o $5^{\circ}$ maior território do mundo, com 8.515 quilômetros quadrados, atrás de Rússia, Canadá, Estados Unidos e China.

Liberdade de movimento refere-se ao grau de autonomia permitida tendo em vista disponibilidade de população, recursos naturais, capacidade industrial, científica e tecnológica. Quanto a população, o Brasil igualmente situa-se entre os cinco grande do planeta; contudo, tendo em vista o território, é apenas o quarto da América do Sul. O Brasil, como vimos anteriormente, tem amplas capacidades em termos de recursos naturais e sua capacidade industrial e de CT\&I é ampla e diversificada.

Já no que diz respeito à coesão interna, diz Meira Mattos, ela “é inseparável das qualidade psicológicas do povo (caráter, nacional, moral nacional, liderança)". O capitulo IV d presente tese se dedicará a este tema.

Arnold Toynbee, renomado historiados britânico, assim conceituava potência: "uma força política que exerce seu poder coordenador num campo de ação maior do que o da sociedade que lhe serve de base". Aqui, toma particular importância a questão da influência nacional junto a seu entorno estratégico. Quanto maior ou menor a capacidade de liderança nacional sobre este entorno, reside em grande medida a definição deste atributo de potência. 
Já Nicholas Spykman, apresenta assim os fatores do poder político: "superfície do território, natureza das fronteiras, quantidade de população, ausência ou presença de matérias primas, desenvolvimento econômico e tecnológico, capacidade financeira, homogeneidade ética, grau de integração social, estabilidade política e coesão nacional". Trata-se de uma relação de atributos de Poder Nacional como vimos anteriormente no debate clássico sobre este conceito.

Já para Steve Spiegel, superpotência "é o Estado capaz de exercer um poder de âmbito mundial, ou seja, ter influência decisiva, na defesa dos seus interesses, sobre acontecimentos que se derem em qualquer parte do planeta”. Aqui a dimensão relativa a defesa dos interesses em qualquer parte prepondera. Conclui-se, portanto, que para este autor, a capacidade diplomática e a força expedicionária, duas dimensões do exercício de poder, devem ser consideradas para uma nação possuir atributo de potência.

Já Kenneth Organsky, em Population and World Power, diz que "o poder de uma nação moderna apoia-se consideravelmente no tamanho de sua população. Com números expressivos, uma nação pode sobrepujar suas deficiências; sem eles, grande poder é impossível. [...] As razoes para esta importância são relativamente óbvias: são os homens que trabalham e são os homens que lutam, mesmo nesta idade de maquinas". Portanto nesta chave de entendimento, o fator demográfico prepondera. Essa condição, contudo, tomada isoladamente, talvez não seja fator determinante para a aferição da condição de potência. Se por um lado é certo que um país de escassa população, mesmo que com grande território não poderá exercer a condição de potência - por exemplo, a Dinamarca/Groelândia -, também é correto afirmar que não necessariamente um país de elevada população será uma potência - caso da Indonésia, por exemplo.

Sintetizando, diz Meira Mattos que "alinhando conceitos vários de potência ou superpotência cuja idade cronologia vem desde o começo do século com Ratzel e Kjállen, passando pelo meio do século com Toybee e Tibor Mende e atingindo a atualidade com Raymond Aron, Spykman, Morgenthau, Spiegel e Schneider. Há que se notar em todos, cinco atributos - dimensão geográfica, população, posse de recursos naturais, capacidade tecnológica e cientifica e coesão interna".

Se tomarmos em conta estes cinco atributos sintetizados por Meira Mattos, veremos que se apresentam tanto fatores estáveis quanto variáveis. No caso brasileiro, dentre os fatores estáveis (dimensão geográfica e posse de recursos naturais) encontramos importantes 
fatores de grandeza no caso brasileiro. Quanto aos fatores variáveis (população, capacidade tecnológica e cientifica e coesão interna), contudo, se revelam vulnerabilidades no caso brasileiro, sobretudo no que diz respeito ao problema demográfico e a coesão nacional.

Não obstante, Meira Mattos conclui dizendo que, "a apreciação dos atributos essenciais de potência selecionados por tantos estudiosos da ciência política e da geopolítica revela a nós, brasileiros, que possuímos todas as condições para aspirarmos a um lugar entre as grandes potencias do mundo".

Para ele, “coesão nacional é um fator inseparável da liderança. Sem essa liderança, as maiorias e minorias nacionais se perderão nos desvãos sectários da polemica estéril e a nação se desencontrará de seu destino". De fato, ambientes de conflagração e de forte polarização nacional - como o que o Brasil vive atualmente -, são pouco propícios a condição de potência. Afinal, quanto maior a unidade e a coesão de propósitos de uma nação, maior será a possibilidade de êxito de seu projeto nacional.

Meira Mattos conclui propondo que "reafirmação do compromisso revolucionário ${ }^{10}$ de, até o ano 2000, alcançar a meta de grande potência". Trata-se aqui da reafirmação do projeto militar do Brasil-potência. Mais amplamente, trata-se de uma aspiração que motivou os brasileiros ao longo do longo período nacional-desenvolvimentista. Urge retomá-lo, corrigindo insuficiências e potencializando caminhos virtuosos.

$* * *$

O presente capitulo se propôs a expor e comentar os fundamentos teóricos a respeito dos conceitos de Poder Nacional, Geopolítica e Grande Estratégia. Nesse sentido nos propusemos a realizar esta apresentação dos conceitos e analise de seus conteúdo a partir daquelas que estão entra as principais leituras - nacionais e estrangeiras - a respeito.

O segundo capitulo seguirá nesta abordagem teórica, desta vez resenhando as grandes teses que embasam a visão realista das relações internacionais.

100 revolucionário aqui se refere às forças militares então no poder, daqueles que que depuseram 0 presidente João Goulart em 31 de março de 1964. 


\section{Capitulo II}

\section{A visão realista das relações internacionais}

O presente capitulo tem como objetivo realizar uma revisão sistemática dos principais autores e conceito que embasam a visão realista das relações internacionais ${ }^{11}$. Este base teórica, junto com o capítulo anterior, permitirão novos passos nas discussões que realizaremos nos próximos capítulos sobre a aplicação destes conceitos tanto às grandes tendências sistêmicas - contemporâneas e prospectivas - do cenário internacional, quanto ao caso brasileiro.

A visão realista guarda forte parentesco com as teorias geopolíticas. Ambas se caracterizam por serem teoria de poder, sendo que a segunda analisa a questão sob a ótica do espaço e da posição do território. Não correto, entretanto, penso, estabelecer relação hierárquica ou de filiação entre uma e outra. Realismo e geopolítica se desenvolvem a partir de escopo próprio, ainda que se relacionam e sejam base para desenvolver o planejamento da ampliação ou realização do potencial nacional.

Aqui, ao iniciarmos, cabe, contudo, um esclarecimento metodológico. As tentativa de firmar uma oposição radical entre as duas grandes escolas da relações internacionais - a realista e a idealista (ou liberal) - devem ser matizadas. Nem os pressupostos teóricos de uma nem da outra devem ser vistos de forma estanque, sem comunicar-se e interagir na realidade.

Afinal, nem o mais ortodoxo interprete realista desconsiderará que arranjos intermediários e temporários se realizam no sistema internacional por meio de alianças e contra-alianças, que por vezes, buscam soluções intermediarias, na forma de equilíbrios que configuram acordos que apaziguam o conflito. Por vezes, estes acordos tomam a forma de instituições internacionais, às quais, terão duração indefinida a depender do tempo em que se sustentar o equilíbrio acordado.

Tampouco a visão idealista ou liberal poderá negar que as Nações, por definição, buscam agregar seus atributos de poder, tendo em vista objetivos nacionais singulares. Nessa

\footnotetext{
${ }^{11} \mathrm{O}$ presente capitulo, baseado na bibliografia listada ao final desta Tese, apoia-se especialmente aqui no excelente Guia das abordagens realistas e da balança de poder, de Eugenio Diniz (Ed. PUC Minas, 2007) e nos originais de Morgenthau, K. Waltz e J. Mearsheimer.
} 
busca por seus interesses vitais, choques são inevitáveis, uma vez que muitas vezes, estes colidem com os de outras Nações. Aliás, as escaladas que resultaram na primeira e na segunda guerra mundial, tiveram a ver com a aspiração por agregar poder, em ações expansionista-imperialista por parte das Nações que as deflagraram. Assim, nenhum arranjo institucional será permanente e estão em função da manutenção de equilíbrios que resultaram de um dada interação de forças.

Assim, a dicotomia idealistas x realistas, como se verá em todo o debate teórico sobre as relações internacionais, não é absoluto. Nas palavras de Diniz (2007, p.20), "Muitos autores, conquanto reconheçam a disputa pelo poder como a dinâmica fundamental da política internacional, não necessariamente consideram instituições internacionais ou o Direito Internacional como irrelevantes ou desprovidos de qualquer efeito; já alguns entusiastas de instituições internacionais, por outro lado, se mostravam atentos ao impacto das relações de forças e de poder".

A propósito do que acabamos de apontar, coube a um autor que se definia como "liberalista-realista", John Herz (1950) expor o "dilema da segurança", que, podemos dizer, constitui um núcleo primário da interpretação realista.

Diz Herz que,

"Onde quer que tal sociedade anárquica tenha existido - e ela existiu em algum nível na maioria dos períodos da história conhecida - surgiu o que pode ser chamado de dilema de segurança de homens, de grupos ou de seus líderes. Grupos ou indivíduos vivendo em tal constelação devem estar, e geralmente estão, preocupados com sua segurança quanto a ser atacado, subjugado, dominado ou aniquilado por outros grupos ou indivíduos. Esforçando-se por obter mais segurança quanto a tais ataques, eles são movidos a adquirirem mais e mais poder de modo a escapar ao impacto do poder alheio. Isto, por sua vez, torna os demais mais inseguros e os obriga a prepararem-se para o pior. Como ninguém pode jamais sentir-se inteiramente seguro em tal mundo de unidades em competição por poder, e o círculo vicioso de acumulação de segurança e de poder está instalado" (apud DINIZ, 2007, p.16).

Esta formulação do dilema de segurança segue a clássica definição de Hobbes a respeito da guerra de todos contra todos, que caracteriza o Estado de Natureza, a qual ocorre, a semelhança dos indivíduos ou grupos de indivíduos no estado primitivo, também no âmbito do sistema internacional. 
No entanto, essa disputa permanente em ambiente anárquico - que caracteriza o ambiente sistemicamente internacional - não leva necessariamente ao domínio de uns pelos outros, ou mesmo a uma regime de guerra permanente, tendo em vista a existência, para a teoria realista, de uma balança de poder.

O estudo empírico destes dois conceitos, dilema de segurança e a balança do poder absolutamente não são novos: estão presentes nas relações internacionais desde a guerra do poloponeso entre Atenas e Esparta, ocorrida há 24 séculos.

Contemporaneamente, a busca incessante da Coreia do Norte por possuir um artefato nuclear é interpretado, por muitos analistas, como efeito da buscar um equilíbrio de poder, com um oponente absolutamente mais poderoso (Estado Unidos), diante de um claro dilema de segurança.

A obra clássica das relações internacionais, Vinte anos de crise, 1919-1939, de E.H. Carr, talvez marque o surgimento do realismo. Nele, Carr, analisando o conturbado e instável período entre guerras, crítica a visão utópica ou idealista que marcou o período posterior a segunda guerra, referindo-se especialmente a experiência da Liga das Nações. Um dos expoentes do pensamento idealista foi exatamente, naquele momento, o presidente dos Estados Unidos, Woodrow Wilson. Esta considerava que a existência de um arranjo institucional conteria a possibilidade de novas guerras.

Retomando uma dicotomia, que na filosofia, aparece na Teoria do conhecimento, lembra Diniz (2007, p.19), os opositores à visão idealista passam a ser identificados como realistas - que se afirmavam como portadores de "um certo monopólio do pragmatismo e do bom senso". Na obra de Carr, os idealistas são vistos como ingênuos bem intencionados.

Hans J. Morgenthau, cuja contribuição à conceituação de Poder Nacional estudamos no primeiro capítulo, também ofereceu importantes aporte a estruturação das bases epistemológicas da teoria realista das relações internacionais, especialmente na discussão sobre teoria de poder e de equilíbrio no sistema internacional. 
Partiremos da definição de Morgenthau a respeito daqueles que o autor identifica como os seis princípios básicos no realismo político ${ }^{12}$. É a base conceitual pela qual inicia o primeiro capítulo de sua obra clássica, “A política entre as Nações”. Vamos a eles.

1 - O realismo político acredita que a política, assim como a sociedade em geral, é governada por leis objetivas cujas raízes se encontram na natureza humana, ou seja, num natural desejo de dominação que as pessoas teriam uma sobre as outras. Assim, "é preciso uma teoria racional que reflita essas leis objetivas", a teoria realista (MORGENTHAU, 2003, P.5).

2 - "A principal sinalização que ajuda o realismo político a situar-se em meio à paisagem da política internacional é o conceito de interesse definidos em termos de poder" (idem, 2003, p.6). Em nossas palavras, a atuação das Nações no cenário internacional parte do princípio de agregação de poder, tendo em vista seus objetivos como unidade que compete nesse sistema. $\mathrm{O}$ autor argumento que é o caso dos políticos, que "pensam e agem em termos de interesses definido como poder, e a experiência da história comprova tal presunção". Exemplificando, diz que, "eles terão que distinguir, como o fazia Lincoln, entre o seu "dever oficial”, que implica pensar e agir em função do interesse nacional, e o seu "desejo pessoal", que é o de ver seus próprios valores morais e seus princípios" políticos ou filosóficos. Ou seja, as razões de Estado (ou o interesse nacional) devem se sobrepor à razões de consciência do líder ou do indivíduo.

3 - "O realismo político parte do princípio que seu conceito-chave de interesse definido como poder possui uma categoria objetiva que é universalmente válida, mas não outorga a esse conceito um significado fixo e permanente" (2003, p.16). Diz George Washington, citado por Morgentahu (2003, p.17), que "o interesse constitui o princípio que tudo governa".

Há, segundo o autor, um núcleo permanente de interesses e um núcleo variável. Este último seria influenciado por fenômenos históricos e pela política interna dos países.

\footnotetext{
${ }^{12}$ Nessa parte, além da leitura dos originais de Morgenthau, nos valeremos da competente interpretação feita por Eugenio Diniz em sua obra anteriormente mencionada.
} 
“Contudo, o tipo de interesse que determina a ação política em um determinado período da história depende do contexto político e cultural dentro do qual é formulada a política externa. As mesmas observações devem ser aplicadas ao conceito de poder. Seu conteúdo e a maneira como é utilizado são determinadas pelo ambiente político e cultural” (2003, p.18).

A ideia de núcleo permanente e núcleo variável de interesses pode ser interpretada na chave que se vê em outros debates aqui apresentados, relativos a necessidade de distinguir aqueles mais vitais e perenes, de outros mais voláteis e conjunturais.

4 - “O realismo político é consciente da significação moral da ação política, como o é igualmente da tensão inevitável existente entre o mandamento moral e as exigências de uma ação política de êxito". Para ele, o "princípio moral" principal, no caso de um Estado, está na própria “sobrevivência nacional”. Assim, "o realismo político sustenta que os princípios morais universais não podem ser aplicado às ações dos Estados em sua formulação universal abstrata, mas devem ser filtrados por meio das circunstancias concretas de tempo e lugar".

Noutras palavras, tendo em vista que o objetivo principal de um Estado é agregar poder visando sobreviver num sistema de anarquia, os "princípios morais universais" possuem relação de subordinação hierárquica em relação ao principal.

Sobre este princípio do realismo, ele se apoia em Lincoln, que dizia:

"Procuro fazer o melhor que posso, da melhor maneira que consigo, e pretendo continuar a proceder deste modo até o fim. Se, no final das contas, as coisas derem certo, o que ora dizem de mim pouco valerá. Se derem errado, não fará a menor diferença que dez anjos jurem que eu estava certo" (p.21).

Ou seja, o julgamento moral do governante ocorre fundamentalmente em função do êxito de sua liderança no enfrentamento e potencialização dos interesses nacionais - "a sobrevivência nacional" - e não em termos de "formulação universal abstrata".

5 - Diz Morgenthau, que "o realismo político recusa-se a identificar as aspirações morais de uma determinada nação com as leis morais que governam o universo". O sistema de valores de uma determinada sociedade não depende de ser aceito pelos demais e tampouco representam uma aspiração universal. Assim, “a equiparação leviana de um 
determinado nacionalismo aos desígnios da providencia é moralmente indefensável”. Por isso, defende "o conceito de interesse definido em termos de poder" porque se tratam de "entidades políticas em busca de seus respectivos interesses definidos em termos de poder".

Trata-se aqui de uma formulação que choca com o idealismo messiânico da política externa norte-americana, a qual, tendo em vista valores derivados de desígnios divinos, julga-se no dever, segundo alguns de seus interpretes, de intervir mundo afora onde estes valores sejam contraditados. Ocorre que por trás dessa pregação idealista, relativa a valores, observam-se pretextos para a manifestação, na verdade, de seus interesses nacionais de agregar mais poder. Eis aqui um exemplo de manifestação idealista com fins não declarados, de natureza realista (agregação de poder).

6 - Conclui, como um sexto princípio, que "portanto, é real e profunda a diferença existente entre o realismo político e outras escolas de pensamento". Assim, “intelectualmente, o realista político sustenta a autonomia da esfera política, do mesmo modo como o economista, o advogado, o moralista sustentam as deles". Esfera política aqui compreendida como política de poder. Com diz Morgenthau, o realista "raciocina em termo de interesse definido pelo poder".

Apresentados estes seis princípios do realismo político, façamos uma incursão por outras dimensões do pensamento de Morgenthau relacionadas a questão do poder.

O autor identifica limites ao exercício do Poder Nacional na política internacional e esse limite é determinado pela balança de poder, por ele assim definida:

\footnotetext{
"A aspiração de poder por parte de várias nações, em que cada uma tenta manter ou alterar o status quo, leva necessariamente a uma configuração que é chamada de equilíbrio de poder, bem como a políticas que se destinam a preservar esse equilíbrio". Para ele, "o equilíbrio de poder e as políticas traçadas para preservá-lo não são apenas inevitáveis, mas são também um elemento estabilizador essencial em uma sociedade de nações soberanas" e "a instabilidade do equilíbrio internacional de poder deve ser debitada não a imperfeição do princípio, mas às condições particulares sob as quais o princípio tem que operar numa sociedade de nações soberanas" (2003, p. 321).
}

A definição da balança de poder é aspecto central para a elucidação da visão de mundo realista. Afinal, o principio hebbesiano da anarquia e da luta num estado de natureza é matizada por equilíbrios, de duração e estabilidade incerta, denominada balança de poder. 
Seguimos adiante. Nas palavras de Morgentahau, equilíbrio é usado como sinônimo de balanço de poder, que significa "estabilidade dentro de um sistema composto de uma variedade de forças autônomas". (p.321-322).

Na visão do autor, há dois padrões básicos de funcionamento de uma balança de poder: o da oposição direta e o de competição, também conhecidas, contemporaneamente, como competição bipolar no caso da primeira e multipolar no caso da segunda.

No primeiro caso, de oposição direta (bipolar) se nação A inicia uma ação imperialista em relação a nação $\mathrm{B}$, esta pode responder com uma política de preservação do status quo ou com uma política imperialista própria em relação a nação A. Neste caso, a balança de poder relaciona-se diretamente ao desejo de cada nação que sua posição prevaleça sobre a oponente, resultando, nesta oposição, que "ou o elo mais fraco cede ao mais forte ou a guerra decide a questão", rompendo o equilíbrio e a balança, portanto.

No padrão competição (multipolar), a disputa entre nação A e B se dá pelo controle político de um terceiro elemento, nação C. A tentativa de A controlar C é contra arrestada pela tentativa de B controlar C e vice-versa. Ambas temerão que o acrescimento de poder de $\mathrm{C}$ leve a um desequilíbrio a seu favor. Assim a independência de $\mathrm{C}$ é determinada pelas relações de poder existentes entre A e B.

$\mathrm{Na}$ análise realista proposta por Morgenthau, vários métodos se apresentam para que se preserve uma determinada balança de poder:

1 - O método de dividir para dominar, que busca manter possíveis competidores desunidos de modo a não reunirem poder suficiente para desafiar a nação que busca preservar a balança. Um segundo método com o mesmo sentido de dividir, diz Morgenthau, é o de nação A agir para fortalecer nação C tendo em vista enfraquecer seu concorrente principal (nação B).

O dividir para dominar é ação clássica na política de poder no sistema internacional e há uma multiplicidade de exemplos que aqui poderiam ser apresentados, quer histórico ou contemporâneo.

Historicamente, é o caso, por exemplo, da persistente ação francesa-desde o século XVII até o fim da segunda guerra mundial - em manter a Alemanha dividida. 
Contemporaneamente, podemos nos referir a ação permanente, por parte dos Estados Unidos, em semear e promover contradições no contexto latino-americano, agindo permanentemente contra a sua unidade política. Por exemplo, as dificuldade políticas do Brasil em seu entorno sul-americano desde a emergência do governos Temer, foram potencializadas com a divulgação, pelo Departamento de Justiça dos Estados Unidos ( $D o J$ em sua sigla em inglês), das relações entre a Construtora Odebrecht e dirigentes de países aliados à Brasília, provavelmente a partir de informações de inteligência.

Sobre isso, ver por exemplo a argumentação de Henry Kissinger, em seu "Precisará a América de uma política externa" (Gradiva, 2003), no qual o estrategista norte-americano fala da "posição de competição tácita" entre Brasil e Estados Unidos em torno da questão do Nafta versus Mercosul (p.89).

2 - A chamada compensação, pela qual, por exemplo, a aquisição de território por uma nação é compensada com a cessão de outro território aquela nação prejudicada, mantendo a balança em equilíbrio.

Não por acaso, o Tratado de Utrecht, de 1713, que pôs fim a Guerra de Sucessão da Espanha é considerado o primeiro a reconhecer, explicitamente, o princípio de equilíbrio de poder por meio de compensações territoriais. No Tratado, literalmente falava-se em "ad conservandum in Europa aequilibrium".

O Congresso de Viena, em 1815, novamente utilizaria o método da compensação, dentre outros exemplos históricos.

A compensação não ocorre apenas envolvendo questões territoriais, mas também outros tipos de barganhas, como "as envolvidas nas negociações diplomáticas, que costumam resultar em concessões políticas”, podendo ser assim associadas organicamente ao equilíbrio de poder.

3 - Um terceiro método refere-se a tentativas de contrabalançar um aumento de armamento de uma nação em relação a outra, resultando também em maior armamento por parte da segunda. Trata-se do que também é conhecido como corrida armamentista. Este método resulta em aumento de custos dos preparativos militares e sensações de 
temores, suspeitas e insegurança. A elas podem seguir, negociações de desarmamento entre as nações resultando em reequilíbrio de poder.

Contudo, historicamente, a mais importante manifestação de equilíbrio de poder se dá não entre duas nações isoladas, mas pelo estabelecimento de alianças. Estas surgem pela celebração de uma aliança entre nações mais fracas em relação a uma nação mais forte, reequilibrando forças.

É o caso do que se viu na América Latina no início do século XXI, com o estabelecimento de coalizões que buscavam reforçar e fortalecer a autonomia destas Nações em relação ao tradicional intervencionismo norte-americano nas Américas. Assim, fortaleceu-se a dimensão política e estratégica do Meercosul; criou-se a Unasul (União das Nações Sulamericanas) e posteriormente, a CELAC (Comunidade de Estados Latino-americanos e Caribenhos).

Entretanto, esse movimento tem como efeito, em geral, o surgimento de uma contra aliança para reequilibrar a balança. Novamente voltamos a América latina contemporânea para exemplificar este feito, que pode ser representado, pelo explicito apoio norteamericano, na presidência de Barack Obama, de constituição da Alianza del Pacifico, mecanismo de países com orientação liberal com orientação simpática a Washington ${ }^{13}$ que, na prática, dividia o esforço de unidade política e econômica da América Latina conduzido e operado a partir de Brasília.

Outra questão importante quanto a alianças, é que, para Morgenthau, "a aliança puramente ideológica, desligada de interesses materiais, não tem condições de sobreviver".

Histórica e hodiernamente, ao observar as tensões entre URSS e China ou entre China e Vietnã, mostra fundamento na argumentação do autor, naquilo que chamaríamos de prevalência do interesse nacional mesmo entre ideologicamente afins.

Por fim, há aquele sistema de equilíbrio que Diniz (2007, p.34), chamou de "fiel da balança", ou, na terminologia original de Morgenthau, o "mantenedor" do equilíbrio ou balanceador.

\footnotetext{
${ }^{13}$ Composta originalmente por México, Colômbia, Peru e Chile.
} 
Trata-se da Nação que, podendo optar por aderir a uma ou outra aliança, tem seu valor político aumentado exatamente pela posição que ocupa. No geral, o fiel da balança optará pela aliança com os mais fracos se daí resultar no desequilíbrio da aliança principal e portanto, em um reequilíbrio da balança. Afinal, o mantenedor não tem nem amigos nem inimigos permanentes mas "interesse permanente em manter o próprio equilíbrio de poder".

Na América do Sul, o histórico papel de pendulo exercido pelo Paraguai e sobretudo pelo Uruguai, é exemplo contundente desse conceito de Morgenthau a respeito da balança de poder.

Com isso, resenhamos esta segunda dimensão do pensamento de Morgenthau que interessa para fins deste trabalho.

$* * *$

Um segundo autor clássico da teoria realista das relações internacionais que aqui no interessa resenhar, tendo em vista uma compreensão de conjunto desta Escola de pensamento, é a figura de Kenneth Waltz.

Seu clássico Theory of internacional politics (1979) é considerado com o representante da abordagem denominada neorrealista ou realismo defensivo. Publicado às vésperas da eleição de Ronald Reagan, este livro foi descrito como a "mais lida contribuição ao neorealismo, que estabelecia Waltz como o sucessor paradigmático de Morgenthau", diz Michael Banks (apud GRIFFITHS, 2004, p.77).

Para esta teoria realista, diferente das proposições observada anteriormente, o foco deve recair na sobrevivência do Estado e não tão somente na busca por agregar Poder.

No prefácio da edição portuguesa que utilizamos aqui para efeito desta seção, LoboFernandes (2002, p.8), credita a esta obra de Waltz "a primeira teoria da balança de poder cientificamente testável”.

Waltz se propõe a pensar a política internacional como uma teoria sistêmica, que afirma a identidade própria deste campo de estudos. Assim, considera que um sistema é constituído de uma estrutura (o sistema) e de unidades em interação (os Estados). 
A teoria sistêmica então "abstrairia as características especificas das unidades em interação, com o propósito de isolar e identificar os efeitos decorrentes exclusivamente da maneira como estão arranjadas as interações entre as unidades, ou seja, os efeitos estruturais" (DINIZ, 2007, P.43).

Partiremos da questão da estrutura, isto é, da caracterização do sistema. Em qualquer dimensão, segundo a excelente síntese de Diniz, Waltz considera que uma estrutura se define a partir da consideração de três aspectos:

1 - pelo princípio da ordenação. Este, estabelece o ordenamento das interações entre as unidades que compõe o sistema, a qual pode ocorrer de duas maneiras:

(a) num sistema hierárquico, cujo princípio seria o da subordinação, através da determinação centralizada de uma instância superior às partes;

(b) pela ausência de uma instância superior às partes, sendo a ordem então definida pelo resultado agregado das decisões e comportamentos individuais das unidades. Tratase então de uma coordenação, não no sentido de algo análogo a uma deliberação coletiva, mas no sentido de que a ordem resulta de decisões individuais de unidades equivalentes. Trata-se então, nesse esquema de coordenação de um sistema anárquico.

2 - pela especificação das funções das unidades do sistema. Trata-se da ideia de que "quando as diferentes atividades executadas no interior de um sistema de interação entre unidades são intensamente repartidas de tal modo que cada unidade realize apenas um número mínimo de atividades e deixando que as demais sejam executadas por outros membros do sistema, diz-se que suas unidades são altamente diferenciadas, cada uma delas executando funções especificas". Como lembra Diniz (p.44), "a ideia é bastante conhecida, em Economia ou Sociologia, pelo nome de divisão social do trabalho".

3 - Pela distribuição dos recursos (capabilities) entre as unidades do sistema. Seja por serem favorecidas pelos mecanismo sociais de distribuição dos resultados das atividades executadas no interior do sistema - através de mecanismos que podem ser justos ou injustos -, seja por reunirem maior capacidade de apropriação dos recursos 
disponíveis no sistema - por mérito ou por força bruta -, algumas unidades podem dispor de melhores condições para executar determinadas tarefas. Estas capacidades diferenciadas podem contribuir para reforçar ou favorecer as regras que a favorecem ou ainda, permitir maior capacidade de apropriação diferenciada de recursos sistêmicos.

Esta última questão é a que mais nos interessa, tendo em vista o escopo deste trabalho, por relacionar-se ao debate sobre meios para o fortalecimento do Poder Nacional. Segundo Waltz, estes recursos são tamanho da população e território, recursos naturais, capacidade econômica, força militar, estabilidade política e competência. Ocorre assim, uma grande competição entre as unidades em torno da obtenção e maximização destas regras e recursos.

Diniz adverte que "em sistemas hierárquicos, essa competição tende a ser regulamentada pela instancia ordenadora central. Em sistemas anárquicos, em função da inexistência de uma instancia reguladora central, as próprias regras serão produto de interações entre as unidades do sistema e serão determinadas pela maior ou menor capacidade de cada uma impor suas preferências; o foco então, recai diretamente sobre o controle dos recursos, e é em torno desse controle que as unidades competem". Quando há muitas unidades aptas a competir no sistema, a competição é generalizada; quando, dentre as unidades, um número menor efetivamente reúne capacidade de disputar, a elas ficam restrita a competição. "Por conseguinte, em sistemas anárquicos, a ordenação será feita a partir das interações entre as principais unidades. A estas, dá-se o nome de polos do sistema” (2007, p.45).

Essa competição por regras e recursos no sistema internacional pode ser observada empiricamente com frequência no atual cenário internacional. Podemos falar, por exemplo, de coalizões ad-hoc que se instituem tentando criar regras na Organização Mundial do Comercio (OMC) mais favoráveis a seus interesses comuns - caso do G-20 agrícola, liderado pelo Brasil durante o período de Celso Amorim (2003-2010) -; quanto a disputa por recurso, por exemplo, salta aos olhos a desenfreada busca chinesa por controle na fonte, em países da África e América Latina, de determinadas matérias-primas essenciais ao país asiático e escassas em seu território. Nessa busca por obter fluxo continuo, a China, vem inclusive financiando obras de infraestrutura que apoie esta 
escoamento e mesmo garantindo certa desobstrução das vias de comercio via patrulhamento extensivo de sua Armada, como é o caso da costa indica africana.

Quanto ao sistema internacional. Para Waltz, não há nenhuma autoridade superior às unidades do sistema, havendo portanto um sistema de natureza anárquica nas relações internacionais; mas não é um sistema sem ordem, sendo esta produzida na interação entre as principais unidades. Como não há autoridade superior, “cada unidade só pode contar, em última análise, consigo mesma para garantir seus objetivos”, numa lógica que Waltz chama de auto-ajuda ("self-help").

Observando o primeiro aspecto da estrutura - o princípio da ordenação - vê-se, portanto, que dada a ausência de uma instância que administre, numa relação de subordinação e hierarquia, as relações entre as unidades, o que prevalece é um sistema de anarquia. Disto deriva uma importante consequência no plano das relações internacionais. Para alcançar seus objetivos, quaisquer que sejam eles, na concepção de Waltz, as unidade precisam necessariamente existir no interior do sistema, pelo que, "o interesse primordial de cada Estado, na política internacional, é estabelecido, teoricamente, como sendo a própria sobrevivência" - afinal, no sistema anárquico, em princípio, não haverá nenhuma forma de se manter se não pela auto-ajuda.

O fato de as unidades do sistema internacional serem Estados não quer dizer que estes são os únicos a interagir internacionalmente. Contudo, "todas as interações internacionais, inclusive entre atores não-estatais, são viabilizadas pelas interações entre os Estados, mas o contrário não é verdadeiro".

No contexto de um sistema internacional caracterizado pela anarquia, onde cada unidade “cuida de si”, é exigido de cada Estado busque executar e dominar o maior número de atividades críticas imprescindíveis a sua existência independente.

Assim, para um dado país, "quanto mais privilegiado em termos de recursos, mais atividades uma unidade de um sistema anárquico tende a executar". Afinal, a não execução autônoma de atividades vitais a sua existência, implica em ficar a mercê de outra unidade que a executa. Assim, em estruturas cujo princípio de ordenação é anárquico, o grau de especialização funcional é necessariamente baixo. Portanto, o segundo aspecto relativo a definição de estrutura que vimos acima, nesse caso de um sistema anárquico, é desconsiderado. Em sistemas anárquicos, "maior interdependência significa maior vulnerabilidade e maior dependência". Deste modo, "sua grande 
preocupação é: ou garantir o acesso a determinado recurso ou mercadoria, ou diminuir sua dependência para com o país que a produza. Assim, tem-se a tendência para um de dois comportamentos: o imperial ou a autarquia e autossuficiência".

Noutras palavras, podemos dizer e destacar, como grande lição aqui o fato de que os Estados nacionais buscam maximizar atributos de autonomia nacional; tendo em vista o funcionamento sistêmico, de natureza anárquica, este imperativo é basilar para a existência virtuosa.

As condições de buscá-la, contudo, não são as mesmas e estão em função do terceiro aspecto da estrutura: a distribuição de recursos no interior do sistema. Estas, como vimos, ocorrem assimetricamente. Assim, a distribuição de capacidades no interior dos sistema é melhor apropriado pelas grandes potências e não pelo número total de unidades que o compõe.

A realidade do sistema anárquico, tem importante consequência sobre o dilema de segurança, no sentido que os Estados são incentivados, a armar-se, como uma decisão racional perante a estrutura vigente; não se armar, ao contrário, é um comportamento punido na estrutura do sistema, ameaçando sua própria existência como unidade autonomia.

Caso se queira evitar, ou pelo menos atenuar, os efeitos estruturais do sistema, a saída é transformá-lo de um sistema anárquico para um sistema hierárquico, ou seja, estabelecer algum tipo de mecanismo central de regulação das interações entre os Estados, num tipo de governo mundial. Para Waltz, entretanto, não é possível nem recomendável, dado que sua existência redundaria em novos conflitos, a começar pelo seu controle. Assim, diz o autor, "a perspectiva de um governo mundial seria um convite para a preparação de uma guerra civil mundial".

Por certo, a estrutura internacional herdada do final da segunda guerra mundial, cujo vértice é o Conselho de Segurança da Organização das Nações Unidas (ONU), não poderá ser caracterizada como um governo mundial. No máximo, ocorrem concertações entre as cinco potencias que o compõe de forma permanente visando intervir em casos mais dramáticos de deterioração de uma das unidade do sistema internacional - caso de massacres e guerras civis, por exemplo. 
Aqui, vale abrir um chave para recordar, por exemplo, das dificuldades de imposição da tese da responsabilidade de proteger $(R 2 P)$, levantada com força no governo de Barack Obama em conjunto com seus aliados europeus. Surgida como proposta de inspiração nitidamente idealista, não tardou por se revelar, notadamente no episódio da Líbia (deposição de Khadafi) como uma ação de natureza imperialista. A rigor, a fronteira entre idealismo e imperialismo é extremamente tênue. Não é raro a manipulação, sobretudo através da agencias de notícias dos países centrais, de bandeiras idealistas, de intervenção "humanitária", para, efetivamente, atender ao interesse nacional do país ou da coalizão de países que a promovem; por exemplo, o interesse europeu por suprimento de petróleo no Oriente Médio.

Falemos sobre a visão de Waltz quanto a Balança de poder e o comportamento dos Estados. Como vimos, a interação dos Estados num contexto de um sistema anárquico é caracterizada pela competição. Desta competição formam-se equilíbrios, na forma de balança de poder, a partir de algumas pressuposições e uma condição.

Dentre as pressuposições, está o fato de os atores unitários (Estados nacionais) buscarem, no mínimo, a sobrevivência, no máximo, a dominação universal; estes Estados buscam utilizar os meios disponíveis visando alcançar os fins em vista; esses esforços podem ser de natureza interna ao próprio Estado ou externa, na forma de alianças. A condição é que estes Estados co-existam num sistema de auto-ajuda. Desse modo, para além dos objetivos de uma Nação ser restrito (sobrevivência) ou máximo (a dominação universal), os Estados atuarão num ambiente extremamente competitivos. Mas, mesmo Estados que almejarem a dominação universal, antes, terão que sobreviver, pelo que, a sobrevivência converte-se em objetivo máximo na política internacional, segundo a interpretação de Waltz.

Em princípio, ou em primeira instância, os Estados buscarão se unir para contra arrestar o mais forte, e não o inverso, que seria buscar juntar-se ao mais poderosos - como, por exemplo, ocorreu com o guarda-chuva anticomunista norte-americano nas Américas, durante a guerra fria. 
No caso de um comportamento de uma intensa corrida para adesão ao mais forte, estaria caracterizado um comportamento que Waltz chama de bandwagoning ${ }^{14}$. Na visão de Waltz, isso ocorreria num contexto em que o Estado que o pratica buscasse a maximização de poder e não o objetivo primordial da sobrevivência.

Assim, para a teoria waltziana de balança de poder, o objetivo primeiro dos Estados no sistema anárquico da política internacional é sobrevivência e não o poder, mesmo se o objetivo for a dominação universal. Ou seja, em vez de aderir-se ao Estado mais forte para maximizar poder, para Waltz, os Estados, mesmo os que aspirem a dominar todos os demais, tenderiam antes de mais nada ao comportamento de balanceamento (balancing). Trata-se então de um comportamento de balancear contra o mais forte.

O balanceamento poderá ocorrer de duas maneiras, não excludentes. Uma, é aumentando a quantidade de recursos à sua disposição, através de esforços internos. Outra, é somar recursos de mais de um Estado, no sentido de formar alianças entre os que compartilham da mesma percepção de ameaça. Aliás, a percepção comum de ameaça é a base para alianças mais estáveis, consistentes. Não por acaso, o Brasil, ato contínuo à constituição do Conselho Sul-americano de Defesa (CDS) da Unasul (União das Nações Sulamericanas), buscou um mecanismo de convergência conceitual e analítica quanto a esta percepção de ameaças entre os países sul-americanos, constituindo, um Centro de estudos Estratégicos e uma Escola de Defesa sul-americana.

Retornando a Waltz, podemos definir que este autor, uma balança de poder define-se pelo equilíbrio a que se chega a partir da competição pela distribuição dos recursos que aumente a chance de cada Estado de sobreviver na política internacional. Assim, o balanceamento ou o equilíbrio, ocorre fundamentalmente pelos recursos do Estado e não pelas alianças que firmam. Como explica Diniz,

“Afinal, em princípio, a formação de alianças é parte do processo político, mas a distribuição de recursos é parte da estrutura. Sendo assim, o poder de cada Estado equivale à sua participação na distribuição de recursos do sistema". Portanto, "a balança de poder para Waltz, portanto, é o resultado das interações entre os Estados na sua busca pelo controle dos recursos que aumentem suas chances de sobrevivência, na medida em que aumentam estas chances". (2007, p.62-63).

\footnotetext{
${ }^{14}$ Que pode ser definido como a estratégia de um Estado mais fraco e débil em se aliar a um Estado mais poderoso para tentar tirar algum benefício nesta relação, ainda que numa relação de subordinação e perda de autonomia. .
} 
No entanto, por definição, não se trata de um equilíbrio estático, pelas características instáveis do sistema anárquico; assim, uma vez rompido um equilíbrio, se buscará estabelecer um novo equilíbrio.

Por fim, vamos percorrer resumidamente, as ideias de Waltz quanto a multipolaridade, bipolaridade e os efeitos da anarquia.

A questão a indagar é: qual o tipo de configuração tenderia a minimizar os piores efeitos estruturais da anarquia?

Para muitos, a resposta mais evidente seria que quanto maior a igualdade entre muitos Estados, menor seria a competição entre eles e os incentivos a cooperação aumentaria. Para Waltz, entretanto, as coisas se passam de maneira exatamente contrária: quanto mais um Estado depender de outros, menos capacidade tem de garantir a própria sobrevivência, mais a mercê dos outros ele está, e menos seguro estará de poder contar com os recursos de outrem quando precisar. Assim, maior interdependência resulta em maior vulnerabilidade. Estas vulnerabilidades tendem a ser assimétricas e assim podem ser exploradas como recursos de poder.

Mirando o caso das interações comerciais entre Estados europeus antes da primeira guerra mundial, Waltz conclui que na medida em que uma maior interdependência aumenta desproporcionalmente as vulnerabilidades, ela tende a incrementar, e não a diminuir, as oportunidades de conflito e guerra. Assim, para Waltz, a existência de desigualdade entre os Estados embora não possa fornecer garantias, ao menos torna possível, a paz e a estabilidade.

Assim, seguindo a chave de pensamento de Waltz, podemos dizer que um quadro de multipolaridade benigna, na qual a interdependência e a relativa igualdade é a regra, tenderá mais ao conflito, ao inverso da visão liberal das relações internacionais defenderia.

Para Waltz, o sistema internacional varia conforme variar a distribuição dos recursos entre as unidades do sistema; isso equivale dizer que o sistema internacional varia conforme o número de grandes potencias ou polos do sistema, isto é, conforme sua polaridade. Então, como as diferenças em termos de polaridade gerariam diferentes resultados na dinâmica do sistema? Busquemos a resposta a partir da constatação de duas configurações principais: a de um quadro de bipolaridade, como a que ocorreu na guerra fria, com dois 
grandes polos a estruturar o sistema, e a multipolar, na qual se verifica a existência de três ou mais potencias. A partir da leitura de Waltz, a interpretação de Diniz é que, "Quando duas potencias competem, desequilíbrios só podem ser ajustados pelos esforços
internos de cada uma; com mais de duas, mudanças nos alinhamentos constituem um
modo adicional de ajuste, acrescentando flexibilidade ao sistema".

Porém, para ele, um sistema com três potencias é inerentemente instável - no sentido de sujeito a transformação. No entanto, dizer que um sistema é estável, não quer dizer que ele seja, necessariamente, mais seguro, mas que ele permanece anárquico; nenhuma variação significativa ocorre no número de partes que o compõem.

No caso de três potencias, será muito difícil uma balancear no caso de uma combinação das outras duas. Assim, um sistema com três potencias rapidamente se tornaria bipolar, pois a aliança para enfraquecer ou mesmo aniquilar a terceira será inevitável” (2007, p.67)

Num sistema bipolar, o balanceamento ocorre principalmente através do fortalecimento interno de cada um dos atores principais. Já no mundo multipolar, "os perigos são difusos, as responsabilidades não são claras, e definições de interesses vitais são obscuras".

Assim, para Waltz, "há uma possibilidade muito maior de acomodação em sistemas anárquicos bipolares que multipolares. Exatamente porque as alianças são menos flexíveis", diminuindo a incerteza e assim, a possibilidade de confrontos.

Além disso, erros de cálculos, em função de se lidar com várias ameaças, aumentam os riscos numa configuração multipolar. Enfim, sistemas bipolares tendem a ser mais favoráveis a cooperação que os multipolares. Assim, para Waltz, a bipolaridade é a configuração básica para a existência de uma balança de poder mais estável.

Esta visão de Waltz tras importantes lições e consequências para a discussão, no escopo deste trabalho, de como o quadro internacional contemporâneo impacta na agregação de Poder Nacional para um país com as características do Brasil. Buscaremos dar consequências a estes elemento no capitulo III.

$* * *$

Um terceiro autor marca a teoria realista e deve ser aqui brevemente resenhado para compreendermos as teses básicas da teoria realista. Refiro-me a John J. Mearsheimer, que no seu clássico The tragedy of great power polics (2001) representa a vertente conhecida como realismo ofensivo. 
Nas palavras do próprio Mearsheimer, na introdução a sua obra mais conhecida, situa sua teoria, a do realismo ofensivo, inserida na tradição de E.H. Carr, Hans Morgenthau e Kenneth Waltz (2007, p.12).

Para o autor, o "fím último" de uma grande potência, "é alcançarem uma posição dominante sobre outros, porque possuir esse poder é a melhor forma de assegurar a sua própria sobrevivência" (2007, p.11).

Argumenta Mearsheimer, ainda a título de introdução a seu pensamento, que,

“[...] o objetivo primordial de cada Estado é maximizar sua quota de poder mundial, o que significa conquistar poder de outros Estados". Para ele, "não há potências situacionistas no sistema internacional, salvo um ocasional Estado hegemônico que pretenda manter a posição dominante sobre as potências rivais. As grandes potências raramente estão satisfeitas com a distribuição de poder; pelo contrário, enfrentam um incentivo permanente para a alterarem a seu favor. Têm quase sempre intenções revisionistas e usarão da força para alterar o equilíbrio de poder caso concluam que isso pode ser realizado com um custo razoável (...) Porém, como não é provável que qualquer Estado alcance a hegemonia global, o mundo está condenado a uma competição perpetua entre as grandes potências" (2007, p.20)

A teoria de Mearsheimer discute as diferenças e a validade das balanças de poder bipolar e multipolar; singulariza a multipolaridade desequilibrada, a hegemonia global e a hegemonia regional, e traz uma contribuição relativamente original à teoria realista por introduzir o papel das balanças de poder regionais em relação à balança de poder global ou sistêmica.

Segundo Diniz, num cartão de visita do realismo ofensivo, "a estrutura internacional gera incentivos para obter poder as custas dos demais. Potências satisfeitas (status quo powers) são raras: maximizar seu poder relativo é a maneira ótima de maximizar sua segurança. A sobrevivência determina comportamento agressivo. 'A situação ideal é ser o hegêmona do sistema"” (2007, p.78).

Passemos aos temas principais abordados por Mearsheimer.

Uma primeira questão é a relativa a anarquia sistêmica e maximização do poder. Para ele, o comportamento agressivo dos Estados na estrutura do sistema internacional, decorre da combinação de cinco premissas, na sistematização de DINIZ (2007):

1 - O sistema internacional é anárquico, sendo constituído por Estados independentes que não estão submetidos a nenhuma autoridade central superior a ele. 
Aqui, ele replica um princípio estruturante de toda a tradição realista das relações internacionais.

2 - Grandes potências, "possuem inerentemente" alguma capacidade militar ofensiva, que lhe permite capacidade de ação, iniciativa.

Não há grande potência desprovida de capacidade expedicionária. Por definição, uma grande potência tem objetivos globais, portanto, terá que ter poder militar que sustente estas pretensões globais.

3 - Os Estados nunca podem ter certeza sobre as intenções alheias, e principalmente, que não poderão ser alvo de capacidade militar ofensiva de outro Estado.

Esta preposição guarda relação com outro princípio clássico do realismo que é o dilema de segurança.

4 - A sobrevivência é o objetivo primário das grandes potências.

5 - Grandes potências são atores racionais.

Assim, as grandes potências reconhecem que seu própria segurança está em função da quantidade de poder que agrega; a busca por ser hegemon no sistema internacional é a forma de melhor garantir a vigência de seus próprio interesses.

Como para Mearsheimer, a possibilidade de obter hegemonia completa é improvável, um Estado não cessará de reunir quando poder consiga, pois agregar poder representa reunir mais capacidade, o que maximiza a capacidade de resistir a tentativas de outros retirarem seus atributos de poder.

Um segundo tema chave na visão de Mearsheimer refere-se a questão das balanças regionais e da hegemonia.

Como dito, os Estados agem para maximizar poder, tendo em vista, garantir sua própria segurança e para se tornar o hegemon global. Mas esta condição dificilmente ocorre pois esta potência se defronta com outras potências estabelecidas, que por sua vez, buscam objetivo similar.

Para o autor, o principal fator de impede um Estado tornar-se o hegemon global, é o que ele chama de poder parador da água (stopping power of water). Para o Mearsheimer, o deslocamento de forças terrestre enfrenta um grandioso obstáculo ao necessitar transpor 
grandes massas de água, desfavorecendo a posição de uma potência extra-regional. As razões vão das condicionantes logísticas à custos e vulnerabilidades.

Por certo, os notáveis avanços tecnológicos em armamento de Defesa, tornam o mundo menor, e mais suscetível a ações estratégicas mesmo de contendores geograficamente distantes. Mas este progresso técnico não se sobrepõe absolutamente a questão geográfica, que segue tendo efetiva centralidade na política internacional, como propõe a geopolítica.

A geografia incentivará que um Estado busque, com maiores possibilidades de êxito a condição de potência hegemônica em sua própria região, em seu entorno. Aqui talvez seja o ponto de contato mais importante de Mearsheimer com a geopolítica, a qual, recordamos, preconiza que a política de um Estado decorre de sua condição geográfica ${ }^{15}$. Com isso, apresentam grande importância a análise de subsistemas do sistema internacional, ou balanças de poder regional, na linguagem do autor. Para ele, potências extra-regionais não possuem força comparáveis a uma potência regional, na luta pelo poder num dado continente, dado o poder parador da água. Isso não elimina que um potência externa àquela região lá atue, exatamente para impedir que outro ator exerça a dominação daquela região, mas o impede se se estabelecer, desde fora, como a potência dominante fora de sua própria região geográfica.

A potência extra-regional provavelmente buscará agir mais por meio indireto, isto é, por cooptação de Estados frágeis e pela promoção da divisão que propriamente por meio da presença direta. Claro que nos referimos à questão militar; do ponto de vista econômico, por exemplo, é absolutamente plausível que uma potência extra-regional busque ter uma presença física importante, inclusive como forma de gerar dependência em relação a ela.

Não obstante, no interior de cada continente, para Mearsheimer, o principal impeditivo a um hegemon será distribuição de poder entre os atores que o compõe, ou seja, qual equilíbrio que será atingido pela balança de poder regional.

Qestão relevante aqui é a aplicação desta questão empregando os conceitos de bandwagoning e de balanceamento. Para Diniz,

\footnotetext{
${ }^{15}$ Esta questão justifica a inclusão deste capitulo que descreve os preceitos realistas neste trabalho. Afinal, como estamos vendo, não apenas são evidentes os pontos de contato com a geopolítica como se tratam de visões afins no que diz respeito a ambas concentrarem-se no estudo dos atributos de Poder.
} 
"É essa consideração, aliás, que permite resolver, de maneira consistente, o impasse teórico mencionado anteriormente, decorrente das considerações de Waltz: quando Estados se aliam a potências (extra-regionais) aparentemente mais poderosa que outra potência (regional) sem sofrer as consequências esperadas para o comportamento de bandwagoning. O ponto é que o poder parador da água - por diminuir o poder concreto efetivamente empregável em outra região - faz com que esse comportamento de fato não seja uma forma de bandwagoning, mas sim, de balanceamento" (2007, p.83).

Para uma potência que logra estabelecer-se como hegemon no âmbito de sua região, a situação ideal - para sua própria segurança - será uma situação de inexistência de outros hegemon em outras regiões, e assim, a ação desta potência dominante em seu continente, buscará impedir o estabelecimento de hegemonias em outros continentes - noutras palavras, o surgimento de novos polos. Idealmente, portanto, estimulará duas ou mais potências numa mesma região. Uma das consequência será que "um país que se encontre na condição de única hegêmona regional tende a tornar-se o aliado preferencial de países que se sintam ameaçados em suas balanças de poder regional” (DINIZ, 2007, p.84).

A história das relações internacional é prodiga em exemplo sobre o acima afirmado. Em primeiro lugar, as grandes potências partem idealmente de uma situação de hegemonia em sua própria região para alçar voos objetivando maximizar capacidade de poder global. Foi, por exemplo, o caso norte-americano quando, ainda no século XIX pôs em pratica os preceitos da Doutrina Monroe. A partir disso é que lhe foi permitindo agir em outras regiões visando, sobretudo, fomentar disputas em outras regiões do planeta que a permitissem estabelecer equilíbrios de poder nas regiões.

Podemos dizer também, em algo que é relevante tendo em vista o escopo deste trabalho, que para tornar-se um hegemon regional ou para preservar esta condição, um Estado deve busca maximizar riquezas - um atributo de poder nacional -, pois essa se traduzirá num incremento da força militar terrestres e portanto, maior condição de alcançar ou preservar o status quo.

Quanto às estratégias para a sobrevivência. Mearsheimer chama de estratégias um conjunto de iniciativas que os Estados podem adotar para aumentar seu poder; para conter um agressor; ou ainda aquelas que não devem ser adotadas por tendem a diminuir o poder de um Estado em relação a outrem (DINIZ, 2007, P.86). Vejamos estas possibilidade, no âmbito das três dimensões, apoiando-nos na síntese de Diniz:

1 - as ações que podem aumentar o poder de um Estado: 
- Guerra. É o principal curso de ação para aumentar o poder, em função de seu grande impacto potencial em termos de resultados. Especialmente a conquista de novos territórios, podem fazer com que o conquistador tire vantagem em termos de riquezas, de posição territorial estratégica ou ainda de conquista que possa excluir o Estado vencido da condição de potência, alterando a balança de poder em favor do vencedor.

- Chantagem. Trata-se da tentativa de coagir um outro Estado pela intimidação e pela possibilidade do recurso à força. Opção muito atraente, pois tende a produzir resultados a um custo comparativamente muito baixo, já que em geral, não efetiva, pelo menos num primeiro momento, ação no terreno.

- Incitamento oportunista (bait and bleed). Aqui, o objetivo será levar dois rivais a se engajarem numa luta prolongada, ao mesmo tempo em que permanece fora e preserve suas próprias forças. Este tipo de ação poderá ser especialmente empregada noutra região geográfica que não a do incitante, num "dividir para governar" - ou pelo menos impedir o estabelecimento de um hegemon regional.

- Sangria (bloodletting). Tentará prolongar uma guerra envolvendo o rival e um outro ator, levando o primeiro a exaustão, consumindo suas forças. Foi o que ocorreu, por exemplo, com a URSS no Afeganistão, no qual uma potência extra-regional - os Estados Unidos - insuflaram e fomentaram a insurgência local levando a um impasse e a posterior retirada soviética.

2 - quanto as ações visando conter um agressor:

- balanceamento. Trata-se do formato em que uma grande potência assume diretamente a responsabilidade de impedir um agressor de alterar a balança de poder, idealmente através da dissuasão. A potência pode sinalizar claramente ao agressor potencial que irá a guerra para preservar a balança. Pode ainda utilizar-se de um balanceamento externo, através de uma aliança defensiva de contenção, ou ainda um balanceamento interno, onde busca mobilizar recursos adicionais, como mais gastos em Defesa ou aumento do efetivo.

- transferência de custo (ou buck-passing). Aqui, trata-se de saber quem irá arcar com os custos do balanceamento. Nessa ação, um Estado, busca transferir a outro ou a outros Estados os custos de balancear (dissuadir ou combater) o agressor, tornando-os buckcatchers.

3 - Por fim, dois cursos de ações que devem ser evitados. 
- Bandwagoning. Para Mearsheimer, ocorre o bandwagoning quando um Estado junta forças com um oponente mais poderoso, admitindo que este novo parceiro obterá parcela desproporcional do que conquistarem juntos. Esta é uma opção, segundo o autor, que só faz sentido para Estados fracos e isolados, sem alternativas.

- Apaziguamento (ou appeasement). Esta opção decorre da percepção que o comportamento agressivo do oponente se deve a um agudo senso de vulnerabilidade estratégica. Para o autor, o propósito de apaziguar um agressor potencial na verdade significa premiar o comportamento agressivo e mostrar fraqueza de vontade ou de recursos, estimulando a agressão ou invés de desestimula-la.

Examinemos agora as posições de Mearsheimer quanto às balanças de poder, situação de medo e comportamento dos Estados.

Para o autor (apud DINIZ, 2007, p.92) o medo (intensidade com que uma dada situação é percebida como ameaçadora para um Estado) varia fundamentalmente de acordo com a balança de poder. Além da situação de hegemonia, que vimos acima, a balança de poder - regional ou global, sistêmicas - pode assumir as seguintes configurações:

- bipolaridade. Caracterizada por grau relativamente baixo de tensão, por ocorrer entre duas potências de poder bélico semelhante, em que uma balanceia a outra. Foi a situação vivida ao final da segunda guerra mundial até a dissolução da URSS em 1991, quando pouco se observou situações de iminente confronto direto entre as duas superpotências exceto em casos como a da crise dos misseis em Cuba, em 1962. No geral, as tensões, e mesmo os conflitos, ocorriam entre Nações componentes de um ou outro bloco.

- multipolaridade equilibrada. Composta por três ou mais potência numa condição de equilíbrio entre elas. Assim, não há hegemonia potencial. A tensão é superior a bipolar, pois balanceamento tende a ser ineficiente e demorado. Esta talvez seja uma situação mais próxima a vivida no contexto anterior à primeira guerra mundial, na qual o declínio da hegemonia inglesa já se fazia sentir, mas todavia não havia um novo hegemon.

- multipolaridade desequilibrada. Igualmente composto por três ou mais potências, dos quais uma é um hegêmona potencial, por deter um poder que os demais, numa condição de assimetria. Nesse caso, atenção é elevada ao máximo. Já que existe risco de uma potência vir a dominar as demais, estas tem um enorme incentivo a atuarem em conjunto - analogias com a situação contemporânea não é descabida, em absoluto. 
Aliás, a situação atual, de transição no sistema internacional, como veremos no próximo capitulo, mostra que nem os Estados Unidos deixaram em absoluto a condição de hegemon - do ponto de vista estratégico, dada sua assimetria em relação aos demais nem as grandes potências que perseguem esta condição - notadamente China e Russia já lograram estabelecer condição de novo hegemon. Talvez por isso é que observamos uma atuação cada vez mais coordenada entre os dois candidatos a hegemon, China e Rússia.

Relevante para efeitos do escolpo deste trabalho, é a identificação que o que define as condições acima é a distribuição de recursos: se este está distribuído de maneira relativamente igual ou se há grandes assimetrias de poder. $\mathrm{O}$ autor ainda insiste na sua posição a respeito do poder parador da água, que limita a capacidade ofensiva de uma potência em relação a outra que esteja noutro continente, por razões geográficas.

Para Mearsheimer, os Estados Unidos são a potência hegemônica nas Américas. Nenhuma outra região do mundo apresenta condição semelhante, pois em todas se apresentam formas de competição regional. Entretanto, para o autor, os EUA não são um hegemon global, uma vez que Rússia ou China teriam capacidade de contra arrestar uma tentativa de domínio de seus territórios. Assim, para o autor, o sistema internacional contemporâneo não é unipolar. Esta observação, dita hoje (2017) certamente é mais razoável do que quando dita por ocasião da publicação da obra de Mearsheimer (2001).

Para o autor a condição de hegemon regional é extremamente vantajosa: "os Estados Unidos estariam na melhor situação concretamente alcançável na política internacional; sua principal preocupação seria apenas impedir o surgimento de um competidor, isto é, de algum outro hegemon em alguma região relevante". A ação estadunidense na Eurásia, quer na balcanização da Rússia preconizada por Brzezinski desde o fim da URSS, que na ação, por exemplo, por buscar fragilizar a posição regional chinesa, são exemplos contundente de que o país segue a risca este preceito.

Nesse sentido, convém aos EUA, segundo o autor, afastar-se das demais regiões e deixar que a própria dinâmica de competição em seu interior impeçam a formação de uma hegemonia; trata-se de uma atitude de balanceador externo que permite transferir os custos e riscos do balanceamento para as potências regionais. Para o autor, "a hipótese mais ameaçadora aos EUA no horizonte próximo" é a capacidade da China se tornar um 
hegemon regional, tendo em vista seu crescimento econômico e sua evidente superioridade em termos de força militar terrestre.

$* * *$

O presente capitulo buscou apresentar, resenhar e identificar os principais conceitos da tradição realista da teoria das relações internacionais - em diálogo com os conceitos da geopolítica e com o conceito de poder nacional - visando identificar questões que nos ajudarão a dar sequência a este trabalho, notadamente na análise das grandes tendências da situação internacional contemporânea, e posteriormente na identificação dos atributos de poder nacional brasileiro. 


\section{Capitulo III}

\section{Grandes linhas e tendências prospectivas da situação internacional contemporânea}

Apresentadas balizas e premissas teóricas desta Tese, realizadas nos dois primeiros capítulos, cabe-nos a discussão aplicada sobre o Poder Nacional e a Grande Estratégia tendo em vista a situação brasileira atual.

Um pressuposto para isto é a análise das grandes tendências da situação internacional, analisando fenômenos conjunturais e prospectivos que impactam no projeto brasileiro de adensamento de seu poder nacional. É o exercício que procederemos neste capítulo.

Para cumprir este plano, percorreremos três sessões no presente capítulo:

- resenharemos grandes tendências propostas em uma série de estudos prospectivos da situação internacional realizados por diversos think thanks, buscando identificar tendências que podem impactar sobre o projeto nacional brasileiro;

- percorreremos os grandes traços da situação internacional contemporânea, buscando identificar fenômenos novos e de maior permanência e de impacto sistêmico e estrutural;

- apresentaremos uma leitura sobre o papel dos BRICS, coalizão que reúne as principais forças revisionistas quanto a ordem mundial;

$* * *$

\section{Estudos prospectivos e planejamento estratégico}

A realização de estudos prospectivos, que busque identificar tendências, é pratica cada vez mais corrente realizada em núcleos constituídos com esta finalidade, no âmbito dos Estados nacionais. Mais recentemente, também começa a se disseminar pelas grandes corporações privadas.

Pode-se dizer que a formulação de cenários deve ser vista como uma pré-condição ao planejamento. Assim, o planejamento, de um Estado um de uma organização, pública ou 
privada, se construirá a partir da análise de probabilidade da ocorrência de determinados eventos. Deste modo, as diversas técnicas de cenários permitirão subsidia decisões tendo olhos no futuro.

Por certo "o futuro não está escrito, mas está por construir-se. O futuro é múltiplo, indeterminado e aberto a uma grande variedade de futuros possíveis" (Goudet e Durance apud Jordan, 2017, p.3). Será uma construção resultado de múltiplos fator e sobretudo das iterações sociais e nacionais.

Contudo, pode-se utilizar de uma conjunto de métodos para buscar identificar estas principais tendência. Fonte importante será a produção acadêmica, em tese e monografias variadas. Estruturação de redes de consultores e realização de seminários é de ampla utilização na confecção destes cenários. Por fim, há diversas técnicas analíticas estruturadas com estas finalidades: brainstorming, impactos cruzados, future wheel, método Delphi, simulações de jogos entre atores, além de diversas opções de softwares e modelos matemáticos.

Os cenários podem ser públicos ou classificados. Se público, podem contribuir por jogar a favor da afirmação de determinadas tendências. Se interno, ao Estado ou a uma organização, pode servir a tomadas de decisões sem expor o plano. Em geral, tratam-se de documentos com atualização cíclica, visando renovar subsídios à decisão e ao planejamento.

Nas palavras do Embaixador Ronaldo Mota Sardenberg,

"Embora seja impossível prever novas descobertas ou invenções, é possível antecipar o sentido geral do desenvolvimentos cientifico e tecnológico num dado período de tempo [...] Obviamente, a capacidade de acerto é diretamente proporcional ao nível e ao volume de informações que se disponha sobre determinado tema e inversamente proporcional ao prazo considerado, razão pela qual a principal ferramenta é a informação e sua metodologia, a prospecção [...] Os estudos prospectivos são, com efeito, um mecanismo eficiente de planejamento, identificação de oportunidades e definição de ações [...] A premissa é de que o futuro não está, em larga margem, predeterminado e, portanto, pode ser moldado pela ação dos atores sociais" (SARDENBERG apud MARCIAL\&GRUMBACH, 2008, p.11-12).

Além disso, cabe fixar que,

"Os estudos prospectivos não tem como objetivo prever o futuro e, sim, estudar as diversas possibilidades de futuros plausíveis existentes e preparar as organizações para enfrentar qualquer uma delas, ou até mesmo criar condições para que modifiquem suas 
probabilidades de ocorrência, ou minimizar seus efeitos" (MARCIAL\&GRUMBACH, 2008, p.18)

As variáveis a serem construídas podem ser denominadas de várias formas. Podem ser identificadas como drivers ou motores de mudança. Ou ainda tendências. Estas tendências podem derivar de temas. Se algumas tendências são firmes, conhecidas e sua evolução se considera bastante provável, podemos ver megatrends. Aquelas de evolução mais imprevisíveis podem ser game changers, uncertainties ou step change. Já eventos de realização altamente improváveis e disruptivas podem ser lidos como wild cards ou ainda cisnes negros (JORDAN, 2017, p.6).

\section{Caso brasileiro}

No Brasil, é relativamente recente a estruturação de cenários prospectivos, que, por obvio, são diferentes metodologicamente de plano e planejamentos - podem servir a estes, mas não são sinônimos.

O governo brasileiro iniciou recentemente suas experiências prospectivas, sobretudo aquelas de caráter público. Experiências de estudos prospectivos de natureza classificada, sobretudo visando oferecer subsídios à formulação de hipóteses de guerra, no âmbito da atividade de inteligência militar, por certo são mais antigas. Mas as públicas são bem mais recentes.

Data de maio de 1994, a realização do I Encontro Nacional de Estudos Estratégicos, organizado então pela recém criada SAE (Secretaria de Assuntos Estratégicos) da Presidência da República junto com o NAIPPE/USP (Núcleo de Análise interdisciplinar de Políticas e Estratégias), desta Universidade de São Paulo. Desde então, realizaram-se treze edições do Encontro Nacional de Estudos Estratégicos, sob o auspicio da SAE, ou em suas ausências, das escolas militares como a ESG (Escola Superior de Guerra) e a ECEME (Escola de Comando e Estado Maior do Exército).

As dez primeiras edições do ENEE, entre 1994 e 2010, foram multitemáticas, abrangentes, buscando uma rosário de temas de natureza estratégica. O último neste formato ocorreu em 2010, voltado a discussão do Projeto Brasil 2022. As edições seguintes, 2011, 2012 e 2013 tiveram diminuído seu escopo e abrangência e enfrentaram questões temáticas, respectivamente, Indústria de Defesa, Programa Espacial e Defesa Cibernética. 
Outra atividade pública que teve relevância na análise de tendência foi realizada no âmbito do Itamaraty (Ministério das Relações Exteriores), através da Funag (Fundação Alexandre de Gusmão) e de seu IPRI (Instituto de Pesquisas em Relações Internacionais). Trata-se da Conferencia Nacional de Política Externa e Política Internacional (CNPEPI), iniciada em 2006 e que neste formato e nome foi realizada anualmente até 2011, em sua sexta edição.

Pelo menos outras três estruturas do estado brasileiro se dedicam, em maior ou menor medida, a realização de estudos prospectivo:

- o IPEA (Instituto de Pesquisa Econômica Aplicada), instituição tradicionalmente subordinada ao Ministério do Planejamento ${ }^{16}$.

- o CGEE (Centro de Gestão e Estudos Estratégicos, vinculado ao Ministério da Ciência, Tecnologia e Inovação (MCTI);

- a ABDI (Agencia Brasileira de Desenvolvimento Industrial), vinculada ao Ministério do Desenvolvimento, Industria, Comercio (MDIC) ${ }^{17}$.

Além dos ENEE e da CNPEPI e da instituições que realizam estudos prospectivos, o governo brasileiro como tal realizou mais recentemente três estudos de projeções a longo prazo:

- o Projeto Brasil 2020, conduzido quando a SAE foi dirigida pelo Embaixador Ronaldo Mota Sardenberg, ainda no governo de Fernando Henrique Cardoso (seminário nacional foi realizado em novembro de 1998);

- o Projeto Brasil em Três Tempos, no âmbito da Núcleo de Assuntos Estratégicos (NAE) da Presidência da República, no início do governo Lula, sob a condução do ministro Luiz Gushiken e do Cel. Oliva, que buscava trabalhar com horizonte temporal de 2007 (final daquele período de governo), 2015 (prazo para o cumprimento das Metas do Milênio das Nações Unidas) e 2022 (Bicentenário da Independência);

- finalmente o Projeto Brasil 2022, conduzido pela SAE dirigida pelo Embaixador Samuel Pinheiro Guimaraes e como vimos, objeto do último ENEE alargado.

${ }^{16}$ O IPEA recentemente publicou dois estudos prospectivos públicos: Megatendencias Mundiais 2030, organizado por Elaine C. Marcial em 2015 e Brasil 2035 - cenários para o desenvolvimento, de 2017.

${ }^{17} \mathrm{O}$ CGEE e a ABDI desenvolvem estudos mais afeitos a temática de inteligência tecnológica e industrial. 
O quadro ficaria incompleto se não observássemos a tradição de estudos prospetivos nas Forças Armadas e no Ministério da Defesa. Com uma tradição mais estruturada na área, a começar pelo trabalho de inteligência militar, contudo, os estudos realizados nestas instituições são de natureza classificada, sobretudo porque são estudos que tem consequências, isto é, incidem sobre o planejamento da Força e mesmo sobre sua organização institucional e programa de armamento.

O Exército Brasileiro, no âmbito do SIPLEX (Sistemática de Planejamento do Exército), realiza estudos prospectivos com horizonte temporal alargado. O último é o Cenários EB 2030. Atualmente, tendo em vista o planejamento de Força (FT-2035), encontra-se em produção do Cenários EB 2035.

A Marinha do Brasil traça, no âmbito de seu sistema de planejamento, prospecções mais afeitas aos aspectos navais. No âmbito da EGN (Escola de Guerra Naval), há importante laboratório de jogos de guerra. Já a Aeronáutica, realiza, no contexto de seu planejamento estratégico iniciativas sobretudo no âmbito da ECEMAR (Escola de Comando e Estado maior da Aeronáutica), voltados a defrontar-se com problemas doutrinário e operacionais.

Mais recentemente, o Ministério da Defesa, a partir da confecções dos documentos estratégicos, instituiu um sistema denominado Sistema de Planejamento de Defesa, SISPED. Este planejamento tem por base o documento Defesa 2035 - Cenários Prospectivos, cuja primeira edição, classificada, foi finalizada no final de 2015.

No âmbito do setor empresarial, empresas como a Petrobras, a Eletrobrás e a Vale do Rio Doce desenvolvem metodologias de cenários $\operatorname{prospectivos~}^{18}$.

$* * *$

A seguir, visando completar esta informação sobre os estudos prospectivos e seus grandes temas, nos debruçaremos sobre um conjunto de documentos internacionais públicos, com horizonte temporal entre 2030 e 2045 , recém resenhado por uma instituição espanhola ${ }^{19}$.

18 Por exemplo, a Petrobras, no âmbito da atualização e seus Planos de Negócios, traça Cenários Prospectivos com horizonte de quinze ou vinte anos, no quais, o cenário energético tem destaque preponderante.

19 Ver "Grandes tendencias políticas y sociales de interes para la Seguridad y la Defensa. Perspectivas europeas y norteamricanas", por Javier Jordán, da Universidad de Granada, no âmbito do Programa 
Esta análise dos estudos prospectivos abarca sete países e duas instituições internacionais ${ }^{20}$.

Por certo, esta revisão é limitada por abarcar tão somente visões oficiais de centros de estudos estratégicos de países desenvolvidos do Ocidente liberal. Deveria-se buscar, num trabalho futuro, refletir também o pensamento não-ocidental, sobretudo de países como a China, a Índia e a Rússia ${ }^{21}$. Mas, por outro lado, dada a abrangência de temas e sobretudo de métodos utilizados nas análises prospectivas dos grandes think-thanks públicos dos países desenvolvidos, isto nos dará uma bom panorama visando a discussão, objeto deste capitulo, quanto às grandes tendências do sistema internacional contemporâneo. Os estudos brasileiros prospectivos mais densos - do Ministério da Defesa e do Exército Brasileiro - não podem ser aqui utilizado tendo em vista serem documentos classificados.

Estudos prospectivos no mundo: grandes temas

Os estudos prospectivos resenhados versam sobre temas que podem ser agrupados em dois grandes blocos, divididos cada em três conjunto de motores de mudanças:

a) Mudanças no sistema internacional

1 - relacionados à multipolaridade, à integração e às dinâmicas cooperação/conflito;

2 - Estados frágeis ou falidos;

3 - sobre globalização e interdependência.

Trabajos de futuro do Instituto Español de Estudios Estratégicos (IEES) do Ministério da Defensa da Espanha.

20 Alemanha, Canadá, Espanha, Estados Unidos, França, Itália e Reino Unidos, além da OTAN (Organização do Tratado do Atlântico Norte) e da União Europeia.

${ }^{21}$ As informações desclassificadas que mais se aproximam da cenários prospectivos encontram-se, no caso destes países, no âmbito dos documento de Defesa regularmente divulgados. No entanto, não se tratam exatamente de estudos prospectivos. 
b) Transformações sociais e politica

1 - questão demográfica;

2 - distribuição da riqueza;

3 - redes de interesses e de identidades.

Passemos aqui a discutir os principais cenários de cada tema.

Primeiramente, quanto aos temas relacionados à multipolaridade, à integração e às dinâmicas cooperação/conflito.

Todos os documentos apontam para uma maior distribuição de poder relativo entre as grandes potencias. Assim, pode-se dizer, há um consenso quanto a uma realidade cambiante quanto ao balanço de forças no sistema internacional. O quadro já não é mais aquele vigente ao fim da vitória ocidental ao final da guerra fria.

No contexto de uma maior distribuição de poder entre os grandes atores do sistema internacional, se é certo que os Estados Unidos ainda figurará como ator chave no próximo período, verá seu poder relativamente erosionado. Quanto a isto há relativo consenso na literatura internacional, mesmo entre autores norte-americanos ${ }^{22}$.

O menor poder relativo dos Estados Unidos deve ser visto vis-a-vis a ascensão China, que já é a primeira economia do mundo em paridade de poder de compra (PPC). A questão a observar é em quem espaço temporal seu poder material se traduzirá em poder militar. No documento britânico estima-se que em 2045 se equipararão os gastos em Defesa de EUA e China. Já os franceses avaliam ser provável a substituição dos Estados Unidos pela China como principal força da Ásia - Pacifico - o que ajuda explicar o reposicionamento geoestratégico norte-americano inaugurado com a política de Obama quanto ao pivot asiático.

Outra questão chave se traduz num paradoxo: se uma guerra entre as potências é improvável, devido aos custos dela resultante, por outro lado a história das transições sistêmicas de poder são acompanhados de conflitos armados na mesma proporção.

22 Ver por exemplo, Parag Khanna (2016), autor de estudo prospectivo de grande sucesso acadêmico nos Estados Unidos. 
Por certo, contudo, não se deve desprezar a interdependência econômica - como a existente entre EUA e China - como fator de certa estabilização.

A rivalidade entre potências pode levar a choque em áreas de influência. Isso se torna tendencialmente preocupante tendo em vista, por exemplo, as ações diretas ou indiretas das potências do velho status quo em relação ao entorno geográfico dos países BRICS, tema que retomaremos adiante.

Se há um certo consenso quanto ao deslocamento do eixo de poder do Atlântico Norte à região da Ásia - Pacífico, permanecem inquietudes quanto a situação chinesa. O "novo normal" - representado pelo declínio das taxas relativas de crescimento econômico poderiam levar a tensões sociais e assim, à instabilidade política na potência asiática.

O declínio do poder relativo europeu pode ser lido através de três tendência: (a) graves desafios de coesão política interna no âmbito da União Europeia; (b) perda de competitividade econômica europeia, derivada de problemas estruturais de sua economia; e (c) retraimento estratégico, com a redução do engajamento na OTAN. Esta última questão, contudo, precisa ser vista a luz da pressão da administração Trump no sentido dos europeus pagarem sua cona junto a OTAN, elevando seus gastos a média de $2 \%$ do PIB, mesmo num ambiente de crise econômica.

As dinâmicas regionais poderão se defrontar com quadros conflitivos por parte de potêcnias que aspiram a hegemonia regional, como se vê em Waltz e Mearsheimer. As situação recentes da Coreia do Norte e do Irã sugerem isso. Podem também ser deflagradas, neste contexto de luta por hegemonia regional, guerras por delegação (proxy wars).

Estes conflitos armados, diretos ou por delegação, terão características de conflitos híbridos "que combinem modos de combate próprios dos exércitos convencionais com comunicação estratégica para deslegitimar e desestabilizar os oponentes, ciberataques e táticas próprias da insurgência, terrorismo, etc (situações também denominadas como conflitos de "zona cinzenta") [...] Por exemplo, mediante recurso a grupos de hackers que realizem ciberataques sofisticados ou redes de jornalistas de investigações aos quais se entregue informação interessada procedente de seriços de inteligência próprios [...minando] a efetividade de ferramentas tradicionais como a diplomacia e a dissuasão" (Jordan, 2017, p.12). 
Relacionado a isto, encontra-se a possibilidade de intervenções militares "a distância", por meio de ciberataques ocultos ou emprego de robôs aéreos ou navais de grande alcance. Foi o caso da campanha norte-americana contra alvos da Al Qaeda em áreas tribais do Afeganistão, politicamente atrativas dado seu baixo perfil e zero de baixas próprias.

Outro fator a destacar é a crescente demanda por recursos. Os documentos canadenses e francês estimam, por exemplo, que a demanda energética crescerá cinquenta por cento em 2040 em relação a demanda atual e 80\% deste aumento se relacionará ao hidrocarbonetos. Para o Brasil, possuído de uma das "ultimas fronteiras" de petróleo e gás novo no mundo, isto converte-se num fator de elevada preocupação geoestratégica. Contudo, este cenário poderia mudar radicalmente se ocorre um salto tecnológico disruptivo a partir das pesquisas por produzir energia segura e econômica. Recorde-se aqui que uma das linhas mais importantes das pesquisas em inovação é exatamente sobre energia limpa (MAZZUCATO, 2014).

Na mesma chave da questão dos recursos, estima-se que em 2035 metade da população mundial sofrerá restrições no consumo de agua potável e mais de 30 países sofrerão escassez grave de agua. Novamente o Brasil, com as maiores reservas hídricas do planeta poderá ver constrangida sua soberania neste cenário.

Quanto a demanda por matérias primas, dentre elas os minerais raros, ocorrerá aumento substantivo, pois estas são fundamentais para tecnologias de uso cotidiano (de computadores a tubos fluorescente a telefones celulares) e militar (como comunicações por satélite e munições guiadas).

Do ponto de vista geográfico, o acesso e transito pelos chamados global commons será outro ponto de sensibilidade estratégica. Nos referimos aqui a Antártida e ao Ártico, às aguas e espaços aéreos internacionais, estreitos e rotas marítimas, espaço exterior (satélites) e ciberespaço. Num quadro de intensificação da disputa geopolítica entre Estados nacionais, o acesso a estes global commons poderá ser dificultado.

Uma segunda questão relacionada a mudanças no sistema internacional diz respeito a Estados frágeis ou falidos - uma realidade bastante presente no contexto europeu, continente cercado por arcos de instabilidade. 
Um primeiro tema aqui refere-se a desequilíbrios demográficos, relacionados a estas Estados. Regiões como a África, o Oriente Médio e a Ásia Central poderão ver explosões demográficas, enquanto e Europa ocidental e a Rússia assistem a taxas de natalidade inferiores a mortalidade. Nas economias avançadas, o declínio relativo da população resultará em problemas econômicos agudos.

Haverá também um incremento importante de megacidades, com mais de dez milhões de habitantes - as quais em 2007 eram dezenove e em 2025 poderão ser vinte e sete. Em 2040 sessenta e cinco por cento da população viverá nas cidades.

Os documentos também mencionam riscos derivados das mudanças climáticas - embora aqui não se deve deixar de considerar as controvérsias em torno delas. Nos textos, alertase sobre riscos resultantes da desertificação e portanto, da perda de terras cultiváveis e da escassez de agua.

No contexto destes Estados frágeis ou falidos, grupo terroristas ou do crime organizado podem emergir; atividade de pirataria podem pôr em risco rotas marítimas. Ao mesmo tempo, poderá observar-se a perda de controle de pandemias de alcance global - como na gripe espanhola de 1918 que dizimou vinte milhões de pessoas ou, mais recentemente, com as ameaças do SARS em 20036 e do Ebola em 2014. Por fim, fluxo migratórios em massa poderão ameaçar a estabilidade de muitos países e regiões.

Por fim, quanto às mudanças na ordem internacional, é preciso atentar-se a questões relacionadas a intensificação da globalização e da interdependência.

Um risco relevante, produto da financeirização capitalista, é o risco de contagio das crises econômicas entre as regiões por estarem integradas num sistema financeiro conectado eletronicamente e altamente reativo. Nesse contexto tampouco se poderá descartar a ocorrência de ataques criminosos ou terroristas contra estas redes.

Questão nova que se apresenta - a um tema clássico da geopolítica - é o problema da porosidade das fronteira derivadas dos avanços tecnológicos. Quanto maior a dependência dos ciberespeço mais vulnerável ficará um país - num contex to em que a as atividade econômicas (Indústria 4.0) e a sociabilidade (internet of things) criará uma onipresença de equipamentos industriais e domésticos controlados pela rede.

O problema da autossuficiência tecnologia em equipamento de Defesa se reforçará, diante da crescente integração das cadeias de fornecimento. Inclusive a um pais como os Estados 
Unidos já resulta impraticável a fabricação nacional de todos seus componentes - não por acaso a administração Trump recém lançou, em julho último, iniciativa denominada "Avaliando e Fortalecendo a Base Industrial e a Resiliência da Cadeia de Suprimentos dos Estados Unidos" ("Assessing and Strengthening the Manufacturing and Defense Industrial Base and Supply Chain Resiliency of the United States”, no original $)^{23}$, que procura abordar desequilíbrios de sinalização nos setores-chave da base industrial de defesa.

Vejamos agora um segundo bloco de tendências, relacionadas a transformações sociais e políticas.

Um primeiro das três tendências refere-se a transformações demográficas. As baixas taxas de natalidade combinada com aumento da expectativa de vida se apresentará como um fenômeno sem precedentes históricos com profundas consequências sociais. Os sistemas previdenciários serão submetidos a forte estresse e poderá ver uma importante queda da produtividade devido a diminuição da população em idade ativa - ainda que esta queda poderá ser mitigada pela nova revolução tecno-científica em curso. Quanto aos já referidos problemas relativos aos fluxos migratórios observar-se-á um incremento das tensões políticas e sociais, como aliás já se ve nos Estados Unidos e na Europa.

Uma outra questão se refere a distribuição desigual da riqueza no contexto destas transformações sociais e políticas. A intensificação da globalização econômica e a ideologia neoliberal subjacente a ela, ao lado das resultantes dos avanços tecnológicos que destroem um grande número de empregos poderá reforçar a divisão entre "ganhadores" e "perdedores", potencializando as tensões políticas, econômicas e sociais. Esta tendência, contudo, deve ser vista relacionada a tema que abordaremos na próxima sessão do presente capitulo relativa ao mal estar da globalização, resultando numa tendência contraditória.

Nos países desenvolvidos atuais, especialmente Estados Unidos e Europa, é provável que prossiga a erosão e a deterioração da classe média, gerando efeitos políticos vultosos.

${ }^{23}$ Ver "Presidential Executive Order on Assessing and Strengthening the Manufacturing and Defense Industrial Base and Supply Chain Resiliency of the United States" in https://www. whitehouse.gov/the-pressoffice/2017/07/21/presidential-executive-order-assessing-and-strengthening-manufacturing (acessado em 03/10/2017). 
Por fim, mas não menos importante, é compreender as consequências do maior protagonismo político da redes de interesse e de identidade.

Manuel Castells, em sua famosa trilogia sobre A era da informação falava do século XXI como o da sociedade em rede. $\mathrm{O}$ acesso amplo a tecnologia seguirá conectando milhões ao longo do planeta. Tendências tecnológicas como a realidade virtual, a realidade aumentada e a melhora significativa de hologramas poderão potencializar estas interações, da mesma maneira que a superação de barreiras idiomáticas por meio da tradução simultânea artificial falada e escrita.

Destes fatores resultam novas tensões, a começar da relação entre Estados e indivíduos. Os avanços tecnológicos, especialmente em matéria de biotecnologia (edição do genoma, aperfeiçoamento de células, clones, bioimpressão em 3D) gerarão questões sociais novas e desafios éticos novos.

As redes de relações entre indivíduos colocará questões novas para a soberania dos Estados nacionais e para seus regimes políticos. Ao mesmo tempo, "a urgência do presente - com ciclos de informação ininterruptos durantes as 24 horas do dia - unidas ao curtoprazismo marcado pelo calendário eleitoral convidarão a descuidar do planejamento e dos compromissos de longo prazo" (Jordan, 2017, p.21).

Ideologias extremistas utilizar-se-ão das redes - como hoje já se vê nos métodos de recrutamento do Estado Islâmico - para potencializar seus adeptos.

O problema democrático se imporá com força, num contexto em que estratos mais jovens da população são os mais intensamente afetados pelo desemprego e a precarização das classe média.

As redes sociais e de identidade também poderão ser instrumentalizadas - e manipuladas - por potencias estrangeiras interessadas em deslegitimar seus oponentes geopolíticos. A comunicação estratégica será cada vez mais intensamente utilizada para influenciar a opinião pública internacional e dos competidores.

A abundancia da informação desacompanhada de ações para convertê-la em conhecimento, sobretudo a partir do sistema educacional, poderá tornar trivial debates de fundo e será terreno fértil para a propaganda. Não por acaso já aparece o tema da pósverdade como aspecto fundamental da época atual. 
As tenências prospectivas da situação internacional que acabamos de resenhar podem se confirmar ou não. Contudo, como fica claro ao longo dos temas que repassamos, muitos destas questões já se apresentam nos dias atuais. Convém grande atenção tendo em vista o interesse nacional.

\section{Grandes traços da situação internacional contemporânea}

Como vimos na sessão anterior, há um virtual consenso na literatura internacional - ou pelo menos, uma ampla maioria de analistas -, sobre estarmos em meio a um momento de transição no sistema internacional, que resultará num novo equilíbrio de forças - uma nova balança de poder - entre as Nações.

Tal compreensão, deriva, de um lado, de dado objetivo, relacionado, a evolução participação das economias no PIB mundial. Afinal, pode-se dizer que há uma relação direta entre base material e capacidade de poder na cena internacional.

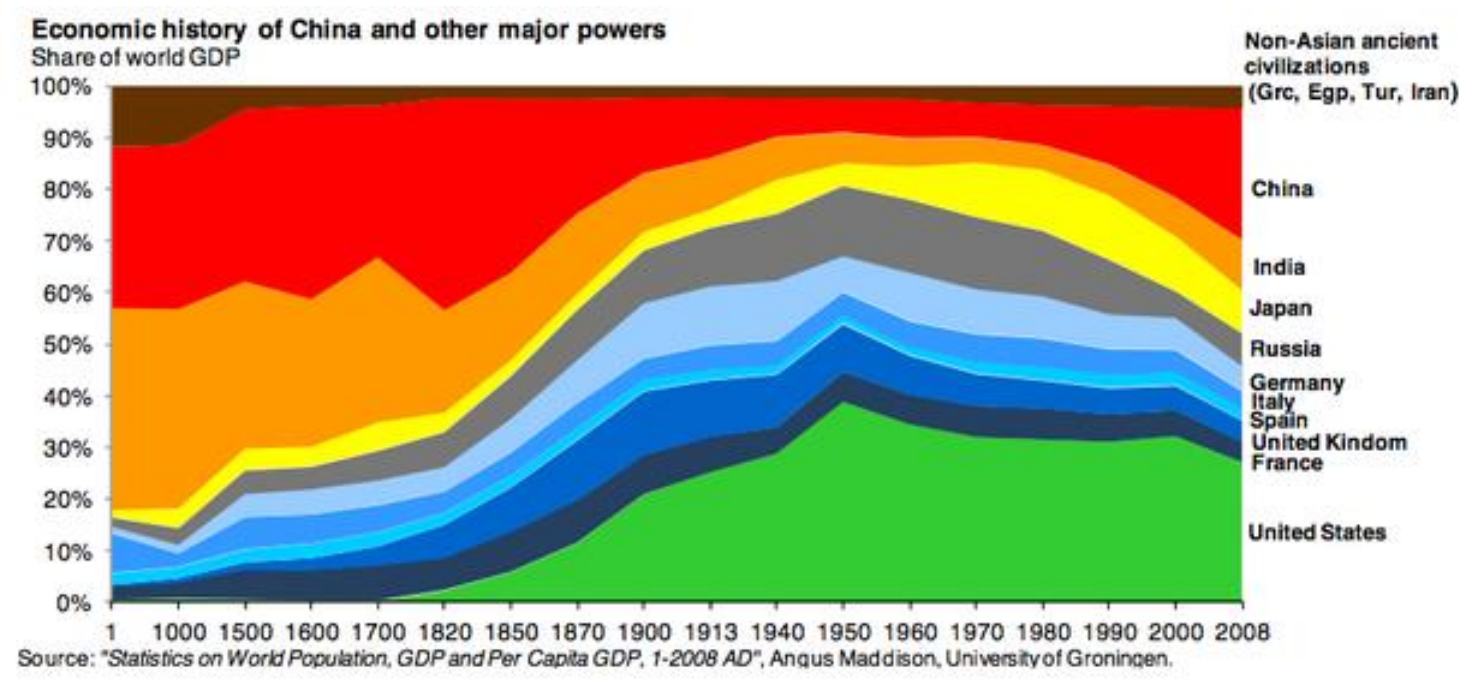

Fonte: http://gulzar05.blogspot.com.br/2010/08/evolution-of-world-gdp.html (acessado em $02 / 10 / 2017)$.

Como se vê no gráfico acima, produzida a partir de extensa pesquisa de Angus Maddison, absolutamente não é constante na situação internacional a condição material das potências; a China e a Índia, que já foram potências materiais declinaram no século XX e neste século XXI, voltam a ascender. Os Estados Unidos, por sua vez, desde que atingiu 
seu auge no pós-segunda guerra mundial, iniciou um declínio relativo que se intensifica neste início de século.

O atual arranjo configura um quadro no qual a multipolarização já é uma realidade, o qual se compõe, por um lado, pela superpotência vitoriosa da ordem bipolar da guerra fria, os Estados Unidos - ao lado de qual perfilam um conjunto de potencias ocidentais, especialmente europeias - ao lado de novas potencias que emergem, especialmente China e Rússia - às quais, rigorosamente, reemergem - ao lado de um conjunto de outros países chamados emergentes. Por identidade e posições assemelhadas, poderemos agrupar estes países como membros do G-7 ou dos BRICS ${ }^{24}$.

No geral, é possível afirmar que estes blocos se dividem entre posições mais conservadoras em relação ao stutus quo - buscando assim a prorrogação da situação pretérita - e de posições reformistas (ou revisionistas) quanto ao sistema internacional. Uns agem por manter congelado o estado de coisas, outros para consolidar a emergência da nova realidade ${ }^{25}$.

A adequação do uso da categoria transição, decorre do fato de que não se pode dizer que se estabeleceu um novo hegemon - ou um novo grupo de potências hegemônicas no sistema internacional; ao contrário, em temas fundamentais da ordem internacional, há posições dispares ou mesmo antagônicas em luta, parte de amplo contencioso a respeito do desfecho da transição atual. Exemplos no plano estratégico, econômico-financeirocomercial, dentre outros.

A categoria transição não impede observar que o grupo de potencias estabelecidas - as vitoriosas da guerra fria, e antes, da segunda grande guerra mundial - não aceitam o vaticínio de seu declínio; mais que isso, manobram fortemente, como veremos, no sentido de renovar suas condições de domínio da ordem emergente, no que podemos denominar

\footnotetext{
${ }^{24}$ Ainda que caibam nesta categorização outros países, como por exemplo a República Islâmica do Irã.

${ }^{25}$ Ainda que esta disjuntiva de objetivos entre tradicionais e emergentes seja absolutamente valida, cabe observar uma matização importante. Por um lado, as potências tradicionais também buscam utilizar as instituições internacionais para criar regras mais favoráveis aos seus próprios interesses - portanto, num movimento de alteração da regras. Por outro lado, contudo, potências emergentes, como a China, tem se valido das regras do sistema internacional quando estas se revelam favoráveis aos seu interesses. Portanto, a despeito de ser correta disjuntivas, se observam matizações importantes.
} 
como uma contra tendência - tendo em vista a tendência estabelecida a transição para um novo arranjo de forças dominantes do sistema internacional.

A China é o principal polo reformista no contexto da multipolaridade - ainda que, como vimos na nota acima, também tenha interesses de manutenção em parte do status quo, especialmente no que diz respeito a certos fluxos da globalização, notadamente o de natureza comercial ${ }^{26}$.

A Rússia e a Índia, outras duas potencias nuclearmente armadas a exemplo da China, conformam com Brasil e África do Sul a coalizão que simboliza o movimento revisionista da ordem internacional - como veremos adiante quanto aos BRICS - numa ação prócíclica em relação a irrupção da multipolarização.

O mal estar. O quadro de transição a multipolaridade, que se apresenta claramente desde meados da primeira década do século XXI, depara-se, contudo, mais recentemente com fenômeno novo e que passa a incidir fortemente sobre o sistema: a crise da globalização. Após uma década da eclosão da grande crise mundial (2007-2008), os países desenvolvidos que a fizeram eclodir, não logram retomar o dinamismo que permita o crescimento econômico, tendo em vista desfuncionalidades sistêmicas do capitalismo.

Vive-se como um "novo normal" no mundo desenvolvido uma era de baixo crescimento - ou melhor, de semi-estagnação permanente -, a despeito dos vultosos estímulos - a começar de muitos anos de juro zero ou negativo - e da retomada de políticas industriais e de inovação.

O resultado é que há amplo mal estar com os efeitos deletérios da globalização. O alto desemprego, a precarização do trabalho e o empobrecimento da classe média começa a se traduzir em políticos de vulto no centro do capitalismo, com evidentes consequências geopolíticas.

No último ano, considerando este momento em que finalizamos a redação desta Tese, quatro das maiores economias do Ocidente liberal foras às urnas - Reino Unido, Estados Unidos, França e Alemanha, em ordem cronológica. Em todos, ou ocorreu resultado eleitoral oposto ao almejado pelo estabilishment liberal - casos do Brexit britânico e depois de suas eleições parlamentares e na eleição de Donald Trump nos Estados Unidos

\footnotetext{
${ }^{26}$ Ver por exemplo o discurso do presidente chinês Xi Jinping no Foro de Davos, 2017, no qual faz enfática
} defesa da globalização econômica e das relações comerciais entre os países. 
-, ou ainda observou importante crescimento de forças antiliberais, à esquerda e à direita - caso da França, no segundo turno entre Macron e Le Pen ${ }^{27}$ e da Alemanha, com a dificuldade de Merkel em formar a maioria. Em ambos caso, registre-se o naufrágio das tradicionais forças centristas (PS na França e SPD na Alemanha).

A "luz amarela" acendeu no estabilishment; muitos alertam para o risco de bancarrota da ordem liberal vitoriosa no pós guerra fria - o "fim da história", na famosa proclamação de vitória apresentada por Francis Fukuyama, segundo quem, a era dos Estados nacionais tinha chegado ao fim; definitivamente, uma proclamação ideológica precipitada, como se vê hoje.

O fato é que as saídas ou opções nacionais entram na ordem do dia na nova conjuntura. Um analista denominou o movimento como um "retorno da geopolítica"28, no que podemos compreender não apenas como o retorno de caminhos de inserção internacional fixados a partir do fator espaço e posição (território) e meio (entorno), bem como na imposição - se é que um dia deixou de ser - de políticas nacionais que buscam maximizar o poder relativo de Nações chaves no sistema internacional - quer no bloco do status quo, quer no bloco emergente.

Noutras palavras, mais que nunca, a geopolítica e as políticas de agregação de poder tendem a ser impor como dominantes no sistema internacional.

Questão chave a observar é a análise sobre qual o grau de autonomia é possível amealhar num sistema internacional construído, nas últimas décadas, para favorecer o estabelecimento de interdependências e fluxos o mais desimpedidos possíveis no contex to da orientação neoliberal da globalização. A resposta a esta questão por certo estará nos clássicos que analisamos no primeiro capítulo, isto é, na capacidade que possui uma Nação de agregar elemtnos de Poder Nacional com vistas a uma maior autonomia relativa. Em seu conjunto, podemos afirmar que instala-se uma era de incertezas a respeito do desfecho da transição no sistema internacional. Este desfecho muito estará em função

\footnotetext{
${ }^{27} \mathrm{Na}$ França, no primeiro turno das eleições presidenciais, mais de $45 \%$ dos eleitores votam em candidaturas com plataformas antiglobalização (Le Pen-FN + Melenchon-FI + Dupont-Aignan-DFL somaram $45,58 \%$ do eleitorado).

${ }^{28}$ MEAD, Walter Russell. The return of Geopolitics. The revenge of the Revisionist Powers. Foreign Affairs, may/june 2014, Volume 93, number 3.
} 
da capacidade das principais unidades nacionais que aspiram ascender - ou se manter no sistema internacional possam agregar quanto a poder relativo.

\section{A eleição de Donald Trump}

A eleição de Donald Trump pode ser considerada como o fato novo mais expressivo do cenário internacional nos últimos anos - para o Estados Unidos, certamente o fato mais relevantes desde o 11 de setembro de 2001.

Esta importância deriva da posição relativa dos Estados Unidos no sistema internacional por um lado, pois apenas da perda de posição relativa, o país segue sendo o principal ator global. A eleição de Trump, inicialmente com plataforma antiestabilshment - sendo ele próprio componente deste estabilishment - representou a grande expressão dos limites da globalização a partir do próprio país que a liderou e promoveu.

A plataforma abertamente crítica de Trump em relação a perda de poder relativo de seu país nas últimas duas décadas, é expressa na ideia-força Make America first again. Portanto, antes que nada, cabe situar Trump e sua ideia-força que embalou sua candidatura e o fez vitorioso como parte de um sentido reativo a perda de poder do país no cenário internacional. Operando por ensaio e erro, Trump manobra abertamente no sentido de reverter a tendência estabelecida.

Cabe destacar, que já em sua posse, Trump abandona o corolário idealista, o qual um novo presidente deveria ser comprometer, tendo em vista a missão norte-americana no mundo, de promocação da democracia e dos valores de sua sociedade.

Cabe observar os movimentos estratégicos fundamentais dos primeiros meses da presidência de Trump. Eles revelam:

- a manutenção e mesmo aprofundamento, no plano estratégico, do foco na contenção da emergência da China, apresentado no governo anterior em substituição à guerra ao terror do pós onze de setembro. Um provocativo aceno a Taiwan foi um primeiro movimento de tensionamento com a China, seguido, meses depois, de uma escalada verbal em relação ao programa nuclear da Coréia do Norte. Resultante da escalada, volta com força a tensão à península coreana, permitindo novas iniciativas norte-americana no plano do posicionamento de forças estratégicas visando a China, com a instalação do sistema THAAD - sigla em inglês para Terminal de Defesa Aérea para Grandes Altitudes. O 
porta-voz da chancelaria chinesa, Geng Shang - dando o tom da gravidade do problema - disse o sistema "irá romper o equilíbrio estratégico regional e agravar ainda mais as tensões na península" ${ }^{29}$. Ao mesmo tempo, permanecem vivas as tensões em torno das disputas territoriais do Mar do Sul da China.

- um segundo movimento pode ser lido na proposta de distensionamento na relação com a Rússia - aliás, já buscada, sem êxito, por Obama em sua política de reset. O movimento de distencionamento com a Rússia pode ser lido como uma tentativa de inverter a lógica de Henry Kissinger ${ }^{30}$. Este movimento, contudo, esbarrou, antes que nada, pela própria reação das estruturas de poder do Estados Unidos - potencializando as denúncias do sistema de inteligência estadunidense de suposta interferência cibernética russa nas eleições a favor da eleição de Trump. Ademais, o movimento esbarra numa viragem da política externa russa, que, a partir dos episódios da guerra da Crimeia, abandonam gradativamente a ambiguidade que historicamente a caracterizou em relação ao Ocidente.

- um terceiro traço a destacar, esta no plano geoeconômico, é a saída, ainda nos primeiros dias de governo, do TPP (sigla em inglês para Parceria TransPacífica). Perseguida com grande prioridade no período Obama, a TPP era muito que um acordo comercial. A rigor, representava a adoção de um conjunto de regras e harmonizações, cujos custos, não representariam necessariamente, nos cálculos da equipe de Trump, vantagem para os Estados Unidos. A retirda do TPP teve forte simbologia inaugural. Pouco depois, a Casa Branca publicaria o texto da política comercial de Trump, que afirma a primazia dos interesses nacionais do país no plano comercial $^{31}$. Pragmática, a ação de política comercial de Trump busca equilibrar déficits comerciais; com a China, por exemplo, busca estabelecer uma espécie de comercio administrado, com concessões mutuas. Em

${ }^{29}$ Ver "EUA iniciam instalação de sistema antimíssil na Coreia do Sul". Valor Econômico, 26/04/2017, em http://www.valor.com.br/internacional/4949532/eua-iniciam-instalacao-de-sistema-antimissil-na-coreia-dosul

30 Nos anos 1970, visando o objetivo principal - a contenção da União Soviética -, os Estados Unidos promoveram uma política de aproximação com a República Popular da China. Agora, o movimento se inverte, e visando a política de contenção com a China, os Estados Unidos promoveriam uma maior aproximação com a Rússia.

31 Ver "The president's 2017 trade policy agenda". Disponível em https://ustr.gov/sites/defaultfiles/files/reports/2017/AnnualReport/Chapter\%201\%20\%20The\%20President\%27s\%20Trade\%20Policy\%20Agenda.pdf (acessado em 01/10/2017). 
pauta também se encontra a renegociação do NAFTA, tratado trilateral com o México e o Canadá.

Em sintese, nossa hipótese central é que a eleição de Trump se enquadra no contexto de uma manobra relancionista pela manutenção da posição norte-americana de hegemon do sistema internacional. A perda de poder relativo dos Estados Unidos nas duas primeiras décadas do século XXI é fato inconteste, inclusive, como vimos acima, por fatores objetivos, como o declínio relativo na participação no PIB mundial. O engajamento norteamericano na globalização, pois, não apenas não tem revertido este dado objetivo, como tem intensificado contradições internas no país, afetando a coesão e a unidade de suas elites em torno do projeto nacional. Não seria funcional a Washington, buscar outro caminho, no sentido de não perecer sem lutar?

A União Europeia é fortemente pressionada pela nova realidade. O BREXIT e a ascensão da tendência antiglobalização no continente aponta o crescimento de uma tendência que abala o próprio arranjo conceitual do projeto europeu. Forças políticas tradicionais definham, a começar da socialdemocracia, cada vez menos diferenciada das forças liberais. Temas como imigração, crise econômica, gastos militares entram na ordem do dia e não há coesão e unidade em torno do projeto europeu. O novo presidente francês, Emmanuel Macron, entusiasta do projeto europeu em crise, propõe "refundar a Europa para combater eurofobia e extremismo"32, em proposta lançada no fim de setembro; as eleições alemãs, dias depois - no qual Ângela Merkel viu erodir sua aliança anterior limitam o campo de ação para esta iniciativa. O projeto europeu segue em crise.

\section{O retorno da geopolítica ${ }^{33}$}

O ambiente geopolítico e geoestratégico global contemporâneo caracteriza-se, fundamentalmente, por um contencioso entre dois polos, cujo desfecho - que poderá

\footnotetext{
32 Ver em https://brasil.elpais.com/brasil/2017/09/26/internacional/1506421196_879623.html (acessado em 30/09/2017)

33 Tomamos emprestado este título do mencionado artigo de Walter Russell Mead, ainda que talvez não seja tão preciso, uma vez que seria altamente questionável argumentar sobre a perda de centralidade da geopolítica; por outro lado, dada a crise da globalização e a emergência de opções nacionais trazem ao imaginário a ideia de retorno da geopolítica.
} 
comportar soluções intermediarias - definirá a nova ordem mundial que vigerá nos próximos dois terços do século XXI.

Os polos são, de um lado, os Estados Unidos e a Europa, o campo liberal ocidental que determinou os rumos do mundo pelo menos desde o final do século XIX. A presidência de Trump e os desencontros do projeto europeu não alteram, no fundamental, a solidez ideológica e de valores deste polo; por exemplo, as manobras que denominamos relancionistas de Trump ou a emergência de forças antiestabilishment na Europa atendem sobretudo a objetivos de natureza interna, ligados aos efeitos deletérios da globalização sobre estas economias nacionais e o emprego.

Outro polo é materializado na aliança sino-russa. Esta aliança vai se coesionando tendo em vista objetivos complementares de ambos países, com poucas ou nenhuma zona de atrito na presente conjuntura.

A fricção geopolítica e geoestratégica entre os dois polos ocorre fundamentalmente em bases territoriais; mais que nunca o espirito de sir Halford John Mackinder ronda o mundo: trata-se do controle da vasta ilha-mundo, em essência de seu núcleo eurasiático.

Nesta fricção, duas iniciativas envolvendo os dois polos se contrapõe, fundamentalmente: por parte do Ocidente, há uma re-emergência dos velhos preceitos da política de contenção, apoiadas sobretudo em estratégias de ação nas fimbrias territoriais da Eurásia - objetivando estratégias de balcanização, como preconizada por Brzezinski ${ }^{34}$ - e na ampla utilização de mecanismos de guerras hibridas - facilitados pela emergência de novos tecnologias e das redes sociais, como vimos acima.

O polo sino-russo manobra, apoiado na força estratégica russa - herança da superpotência militar soviética - e na ampla capacidade material chinesa.

Busca a Rússia de Putin, antes que nada, ativar uma estratégia de resistência contra a tentativa do Ocidente de balcanizar seu território e reposicionar sua esfera de influência. Isso explica, anos atrás, o fomento ocidental das chamadas revoluções coloridas ${ }^{35}$, e mais recentemente, os episódio na Ucrânia e, em parte, na Síria.

34 Ver BRZEZINSKI, Zbigniew. El gran tablero mundial. La supremacia estadunidense y sus imperativos geoestratégicos. Barcelona: Ediciones Paidós, 1998.

${ }^{35}$ Revoluções coloridas é como ficaram conhecidas uma série de manifestações políticas de oposição que envolveram a derrubada de governos considerados antiestadunidenses, e sua substituição por governos pró-Ocidentais, ocorridas a partir dos anos 2000 , em países com democracias recentes, ou em processo 
Já a China busca aumentar sua influência no mundo sobretudo tendo em vista objetivos internos. O país, ao passo que vai ascendendo a condição de principal economia do mundo, realiza internamente uma transição de modelo de desenvolvimento no qual busca apoiar preponderantemente em fatores internos seu crescimento econômico - chave para a estabilidade política e consequentemente social.

Através de vultosa capacidade financeira, busca garantir fluxos estáveis de bens e matérias primas pelo mundo, ao lado de gerar novos polos de dinamismo para sua expansão econômica. Nesse sentido anuncia o que talvez seja o maior projeto de investimentos em infraestrutura da história, potencialmente superior ao Plano Marshall, promovido pelos norte-americanos no pós-guerra. Trata-se da iniciativa conhecida como OBOR, sigla para One Belt, One Route - traduzido em português como Um Cinturão, Uma Rota -, que busca estruturar e organizar fluxos que lhe permitam escoar sua produção e receber bens e recursos fundamentais para seu próprio desenvolvimento. A iniciativa é potencializada pelo aparecimento de instituições espelho dos organismos financeiros tradicionais como o FMI e o Banco Mundial - fortemente hegemonizados pelo Ocidente, refletindo essencialmente o quadro de forças do pós-guerra. Nos referimos aqui ao aparecimento do Asian Infrastructure Investment Bank (AIIB) e do New Development Bank (NDB), este último, o Banco dos BRICS, surgido em Fortaleza (CE), como veremos adiante.

A iniciativa OBOR tem uma dimensão terrestre e outra naval. Deve ser lida, a pesar da negativa chinesa, pelas chaves geopolítica, geoeconômica e geoestratégica. Em grande medida trata-se de manobra territorial diante da política de cerco e contenção a que é submetida. Pode-se dizer que a China ressuscita Mackinder e Mahan. Afinal, a nova rota da seda terrestre busca conectar um extremo a outro da Eurásia (litoral chinês ao litoral europeu) passando pelo heartland mackinderiano ${ }^{36}$. Já a rota marítima, busca definir um

de democratização, na área de influência ou no território da antiga União Soviética. Estas manifestações têm em comum um discurso de democratizante, liberal e pró-ocidental, com destacado papel de ONGs, organizações estudantis e da mídia. Dentre as revoluções coloridas, estão a Revolução Bulldozer, em 2000, então na lugoslávia, na Geórgia (a Revolução Rosa, em 2003), na Ucrânia (a Revolução Laranja, em 2004), e no Quirguistão (a Revolução das Tulipas, em 2005). Outros processos semelhantes ocorreram sem 0 mesmo sucesso nos anos 2010, no Egito, Venezuela, Líbia, Síria e Ucrânia. Há que se destacar nestas revoluções, o papel desempenhado por agentes externos, principalmente por norte-americanos - CIA, Open Society Foundations (do magnata George Soros), USAID e o National Endowment for Democracy.

36 Um importante antecedente da Rota da Seda terrestre está no estabelecimento, em 1996, da Organização de Cooperação de Xangai (OCX). A OCX é composta por da China, Cazaquistão, Quirguistão, Rússia, Tadjiquistão e Uzbequistão. Estes países, à exceção de Uzbequistão tinham sido membros dos 
conjunto de vias livre de navegação, que inclusive driblem possíveis estrangulamentos militares de estreitos por qual passam a maior parte das exportações e importações chinesas, como, por exemplo, o estreito de Malaca. Seguindo a velha recomendação de Mahan, buscam expandir um sistema de rotas bases comerciais, às quais podem inclusive ter uso estratégico, como já se vê no caso de Djibuti ${ }^{37}$.

Numa importante demonstração de força, a China promoveu, em 14 e 15 de maio de 2017, em Beijing, o "The Belt and Road Forum for International Cooperation”, com a presença de 30 Chefes de Estado e mais de 1.500 delegados, estudiosos e empresários de 130 países, além de representantes e autoridades de 70 organizações internacionais ${ }^{38}$. Proposta inicialmente pelo presidente chinês Xi Jinping em 2013, menos de um ano após assumir a presidência da China, a iniciativa OBOR inspira-se no grandioso passado do Império do Meio. No discurso original em que apresenta a iniciativa, $\mathrm{Xi}$ alude diretamente a figura do emissário chinês Zhang Qian, que há 2.100 anos atrás realizou missão pela Ásia Central $^{39}$. Para a versão marítima da rota da seda, tampouco faltam referências a Zheng He, navegador chinês que no séculos XIV e XV realizou ousadas expedições, chegando então ao distante estrito de Ormuz.

A manobra chinesa atende também às necessidade de desenvolvimento do Oeste do país, onde minorias étnicas (Tibetanos e muçulmanos de Xijiang) tem sido assediados desde fora com intentos secessionistas.

Outra questão da mais alta relevância geoestratégica é a disputa que ocorre atualmente no chamado Mar da China - principal Teatro de Operações geoestratégico naval do mundo contemporâneo. Neste ambiente, ocorre um contencioso que deflagra uma nova

Cinco de Xangai, fundada em 1996; após a inclusão do Uzbequistão em 2001, os membros rebatizaram a organização. Em julho de 2015, a OCX decidiu admitir a Índia e o Paquistão como novos membros plenos.

${ }^{37}$ A primeira base naval chinesa no exterior foi inaugurada em agosto de 2017. "Sua finalidade, de acordo com Pequim, é dar apoio logístico aos contingentes chineses que participam de várias missões das Nações Unidas na região, principalmente as tropas que fazem parte dos capacetes azuis no Mali e no Sudão do Sul e às que realizam operações contra a pirataria no golfo de Áden e na costa da Somália". Ver https://brasil.elpais.com/brasil/2017/08/01/internacional/1501589492_007630.html (acessado em 20/09/2017).

38 Ver "O fórum da amizade". Reportagem da Revista China Hoje, número 14, Ago/Set de 2017.

39 "Construir juntos o Cinturão Econômico da Rota da Seda" (07/09/2017) in Xi Jinping - a governança da China. Editora de Línguas Estrangeiras, Beijing, 2014. 
Revolução de Assuntos Militares. Lá, há alguns anos desenvolvem-se ações que se conhece na literatura como A2/AD (sigla para anti-access/area denial) ${ }^{40}$ e sua resposta, o chamado "terceiro offset". Trata-se do desenvolvimento de tendências da guerra moderna, entre a estratégia chinesa de negação de acesso e de área e a resposta norteamericana conhecida como "terceiro offset". Nesta contenda, a batalha cibernética atinge importância impressionante $e^{41}$.

Chama atenção, como tendência da guerra moderna com grandes implicações estratégicas, o uso de plataformas como Navio e submarinos dotadas da capacidade de misseis balísticos visando ataques cada vez mais cirúrgicos - como se vê com a Rússia, com plataformas posicionadas no Mar Cáspio contra alvos terroristas na Síria.

Em síntese, o contencioso geoestratégico contemporâneo voltam a estar relacionada a dois fatores clássicos da geopolítica, por nós analisados em Dissertação de Mestrado ${ }^{42}$ :

- o domínio da Eurásia, nos termos de Mackinder;

- uma nova luta pela supremacia dos mares, e, mais amplamente, pelos "global comuns", nos termos propostos por Mahan.

Assim, chegamos ao três pontos críticos de tensão geoestratégica do mundo contemporâneo:

No primeiro caso, terrestre, as duas das zonas de fricção estratégica terrestre localizamse nas fimbrias ocidentais da Eurásia: a Ucrânia / Crimeia e a Síria. Note-se, que ambas crise foram deflagradas a partir de mecanismos de guerra hibrida, ou ainda, ações de regime change, sucedidas por movimentos baseados no conceito de R2P (Responsabilidade de proteger, em inglês Responsibility to Protect).

\footnotetext{
${ }^{40}$ Isto é, estratégia dedicada à negar acesso (anti-access) e área (area denial).

41 O curso da RAM no Mar da China tem enorme importância para o Brasil; cabe-nos acompanhar com grande atenção 0 desenrolar desta realidade: são tendências que poderão, num futuro incerto, aplicar-se ao TO do Atlântico Sul, sobretudo se confirmadas tendências de guerras por domínio de recursos naturais.

42 Ver CARMONA, Ronaldo. "Geopolítica clássica e Geopolítica brasileira contemporânea: Mahan, Mackinder e a "grande estratégia" do Brasil para o século XXl". Dissertação de Mestrado. Universidade de São Paulo (USP), 2012.
} 
A terceira zona de fricção geoestratégica, esta naval, localiza-se, como vimos acima, nos mares do Oriente, do estreito de Malaca e Mar do Sul da China até o Mar do Japão.

A retomada, pelas potencias estabelecidas, da geopolítica da contenção voltada aos BRICS

Busquemos explorar a geopolítica da contenção observando as ações voltadas aos países BRICS. Como disse, os BRICS se posicionam como símbolo da multipolarização, do novo balanço de forças que vai emergindo. Imediatamente, entram na linha de tiro. Não se trata de novidade; está na raiz do pensamento estratégico norte-americano, a ideia de conter, por meios híbridos e diversificados, o surgimento de atores que tendencialmente contribuam para erodir a dominância do país no sistema internacional. Spykman, Kennan, Brzezinski e outros justificam conceitual e teoricamente o que o documento The National Military Strategy dos Estados Unidos, de 2015, chamou de foco em relação aos revisionists states da ordem mundial ${ }^{43}$.

As ações principais são:

- pressões contra a coesão nacional

- ação voltada a pressões contra o entorno geográfico; nas palavras do chanceler chinês, “caos às nossas portas" 44 .

Historicamente, a ultrapassagem de uma potência estabelecida por outra ocorre em contexto de vitória militar ${ }^{45}$. Na atual transição observada na situação internacional, entretanto, a ultrapassagem ocorrerá primeiramente pelo poder material. A superação da economia norte-americana pela China já é fato, com base no critério de paridade do poder de compra, ou seja, o peso relativo das economias pelo custo de vida real. Contudo, a ultrapassagem econômica, não leva a imediata ultrapassagem nem em termos de liderança política muito menos em termos militares.

\footnotetext{
${ }^{43}$ Ver www.jcs.mi/Portals/36/.../2015 National Military Strategy.pdf (acessado em 01/08/2016).

44 Ver "O papel da China sob a era Trump", Valor Econômico, 28/04/2017, em http://www.valor.com.br/cultura/4950968/o-papel-da-china-sob-era-trump

45 Ver, dentre outros, "Ascensão e queda das grandes potências", de Paul Kennedy (Ed. Record, 1989) e "Os Impérios na História", org. Francisco Carlos Teixeira (Ed. Campus, 2009).
} 
Não estando em tela neste momento um confronto militar direto, como vimos, os países do status quo atuarão fortemente no sentido de operar uma contra-tendência, que nesse momento atende essencialmente pela reabilitação das velhas doutrinas geopolíticas da contenção.

Sugerida por Spykman, a estratégia da contenção toma forma a partir de celebre artigo de George Kennan intitulado "The Sources of Soviet Conduct", publicado na Foreign Affairs, em 1947. Nele, o então embaixador norte-americano em Moscou começa a delinear o que inicialmente seria conhecido como Doutrina Truman e que finalmente levaria os Estados Unidos a vitória na guerra fria, com a desintegração da União Soviética.

Contemporaneamente, Brzezinski (1998, p.201), é explicito ao defender que "a tarefa mais imediata é se assegurar que nenhum Estado ou combinação de Estados obtenha a capacidade de expulsar os Estados Unidos da Eurásia ou de limitar significativamente seu decisivo papel de arbitro" 46 .

Fatos recentes do cenário estratégico global sugerem que por meios diretos ou indiretos, abertos ou encobertos, ostensivos ou sutis, os BRICS são objeto, neste momento, individual ou coletivamente, do que podemos denominar como uma reabilitação da geopolítica da contenção.

No governo Obama, especialmente, anunciou-se a estratégia que é conhecida como "pivot" ou "rebalance” para a Ásia. No que certamente representou a principal novidade geoestratégica do último período, ocorre o aparecimento do documento com o sugestivo titulo de "Sustentando a liderança global dos EUA: Prioridades para a Defesa do Século 21 " (Sustaining U.S. Global Leadership: Priorities for 21st Century Defense), em $2012^{47}$.

A nova geoestratégia norte-americana suplanta a fase anterior - da guerra ao terror, vigente desde os atentados de 11 de setembro de 2011 - e busca responder à grande

\footnotetext{
${ }^{46}$ Aqui, para além da atuação nas fímbrias, Brzezinski defende a intrusão direta na heartland. Vale lembrar, no período recente, o estabelecimento, pelos Estados Unidos, tendo como pretexto a guerra no Afeganistão, de suas bases militares em dois países da antiga União Soviética: em Karshi-Khanabad (Usbequistão) e em Manas (Quirquistão). Devido a pressão combinada da Russia e da China, sobretudo a partir da Organização de Cooperação de Xangai, os Estados Unidos deixaram estas bases respectivamente em 2005 e 2014 (junho).
}

${ }^{47}$ Ver http://www.defense.gov/news/Defense Strategic Guidance.pdf. Acessado em 01/10/2014 
alteração geopolítica em curso no início do século XXI: a lenta, mas efetiva erosão do poder das potências tradicionais do Ocidente, por um lado, e por outro lado, a crescente - e ainda que não sem percalços e obstáculos - ascensão dos grandes países em desenvolvimento, simbolizado na aliança BRICS e tendo sua expressão mais vistosa na China - a $2^{\mathrm{a}}$ economia mundial e em vias de tornar-se a primeira.

Assim, desde 2012, os Estados Unidos passam a focar sua estratégia militar na região da Ásia e Pacífico, mais precisamente na contenção da China. Essa postura estratégica é confirmada no último Quadrennial Defence Review (QDR), enviado ao Congresso norteamericano no último 04 de março de $2014^{48}$.

Ademais, a geopolítica do contenção atua fortemente no sentido de fomentar divisões e instabilidade no entorno estratégico de cada um dos BRICS. Há caso mais evidentes, como vimos acima, como a atual tensão na fronteira russo-ucraniana, atentativa de mudança de regime na Síria ou o conturbado Mar da China.

Mas também a contenção ocorre em casos menos percebidos, como no controle do Atlântico Sul pela OTAN, a partir de um "cordão de ilhas" e com a permanente campanha que busca fraturar a integração sul-americana, seja por meio de fomento de instabilidade em países como Brasil, Venezuela e Argentina, seja através de intervenções abertas através de prepostos, como é a criação da Alianza del Pacífico, com nítidos propósitos geopolíticos voltados contra o Brasil.

Em cada um dos BRICS também se identifica pressões sobre fator chave para a ascensão de um país no sistema internacional: a coesão nacional. A Rússia é permanentemente pressionada pelo fator étnico, quer por tendências centrífugas por parte de minoria em seu território (os chechenos, por exemplo) quer por ameaças a seus nacionais residentes em antigas republicas soviéticas. A China vive sob constante ameaça territorial relacionada ao Tibet e a minoria urguir em Xinjiang. A Índia é pressionada por uma tensão constante entre a maioria hindu e a minoria muçulmana. A África do Sul permanece, duas décadas após o fim do apartheid, como problemas de natureza racial. Mesmo o Brasil, caracterizado por uma formação social miscigenada, não foge a regra: além do fomento ideológico do multiculturalismo - por parte de endinheiradas agências estrangeiras -,

\footnotetext{
${ }^{48}$ Ver http://www.defense.gov/pubs/2014_Quadrennial_Defense_Review.pdf. Acessado em 01/10/2014.
} 
absolutamente estranha à formação social brasileira, é constantemente pressionado por manipulações quanto a questão indígena, dentre outras pressões de natureza racialista.

Ameaças ao BRICS, em seu caminho de ascensão, também ocorrem pela própria deterioração da situação internacional, a partir da incorporação de determinados conceitos à "ordem jurídica" multilateral. É o caso do conceito de responsabilidade de proteger, que tem dado margem para guerras "humanitárias" ou "civilizatórias" modernas, bem como ações indiretas de regime change, conceito pelo qual tem sido denominado golpes de Estado contemporâneos.

\section{O papel dos BRICS}

A necessidade de jogar luzes sobre os BRICS decorre do fato de que a coalizão revelou ser a iniciativa de maior vulto no sentido de incidir sobre a ordem geopolítica global neste início de século $\mathrm{XXI}^{49}$. Afinal, a convergência de cinco grandes países em desenvolvimento em torno do interesse nacional comum de ascender, e para isso, reformar o sistema internacional foi o amalgama que coesionou os BRICS no período que vai até a Cúpula de Fortaleza (2014), período até o qual o Brasil manteve uma orientação autonomista em política externa. Assim, nossa opção, nesta sessão, de interpretar a trajetória dos BRICS até Fortaleza, decorre desta orientação geral até então vigente na posição brasileira $^{50}$.

A $6^{\text {a }}$ Cúpula do BRICS, em julho de 2014, marcou o início do segundo ciclo de reuniões anuais dos Chefes de Estado de cinco grandes nações em desenvolvimento do mundo ${ }^{51}$,

\footnotetext{
${ }^{49} \mathrm{~A}$ presente sessão é resultado de amplo monitoramento do processo de construção dos BRICS ao longo do período de doutoramento, que incluiu pelo menos quatro artigos a respeito, listados nas referências bibliográficas, um deles, objeto de conferencia em encontro internacional de estudos estratégico.
}

${ }^{50}$ A Cúpula de Ufa, na Rússia, em 2015, ainda sob a presidência de Dilma Rousseff, já se realizava sob efeitos da forte crise brasileira. As Cúpulas seguintes, em Goa, na Índia (2016) e em Xiamen, China (2017) foram marcadas por uma posição do Brasil, em boa medida, diversa; por exemplo, em Goa, foi marcante a oposição brasileira ao estabelecimento de uma agencia de rating própria do mecanismo; já na China, além de manter a presença discreta quanto aos grandes temas da situação internacional, o Brasil exibiu uma pauta marcadamente mercantilista. Este conjunto de questões, justifica, ler a evolução dos BRICS, nesta sessão, até a reunião de Fortaleza em 2014.

${ }^{51}$ Com as edições de Ecaterimburgo, 2009, Brasília, 2010, Sanya, 2011, Nova Delhi, 2012 e Durban, 2013 completou-se um ciclo no qual os cinco integrantes do BRICS sediaram reuniões de Cúpula; Fortaleza inaugurou novo ciclo. 
e, como argumentaremos, marcou salto qualitativo da aliança, uma nova fase, fortalecendo a tendência a um mundo policêntrico.

As decisões tomadas em Fortaleza, especialmente a criação de um Banco e de um Fundo de reservas do BRICS, como veremos a seguir, a medida em que efetivadas na sua plenitude, potencializarão a margem de manobra de cada um dos integrantes dos BRICS e destes como conjunto, permitindo maior autonomia destes países no cenário internacional.

Representando pouco mais de $40 \%$ da população mundial e quase 1/4 da economia global, os BRICS são objeto de atenção pelo ineditismo e singularidade de uma agrupação com estas características: é a mais relevante coalizão global a não incluir a presença das potências estabelecidas, do velho status quo.

O primeiro ciclo de Cúpulas presidenciais - realizadas entre 2009 e 2013 - foi marcado por consolidar os BRICS como instrumento de coordenação política de grandes países em desenvolvimento quanto aos principais temas da agenda internacional. Já o $2^{\circ}$ ciclo, iniciado em Fortaleza, inaugurou a institucionalização do bloco, através da criação de meios para intervir mais solidamente na ordem internacional contemporânea.

A partir da reunião de Fortaleza, os BRICS passam a contar com instrumentos institucionais para operar mudanças na arquitetura financeira e monetária internacional: o Novo Banco de Desenvolvimento (NDB, em sua sigla em inglês), o Banco dos BRICS e o fundo comum de reservas dos BRICS, chamado formalmente de Arranjo Contingente de Reservas (CRA, na sigla em inglês).

Ademais, a reunião de Fortaleza marcou importante lance na grande partida de xadrez que se joga no tabuleiro geopolítico mundial a respeito de qual será o desenlace e o desfecho da atual transição em curso no sistema internacional, como argumentamos acima, neste capítulo. Afinal, as decisões tomadas na $6^{a}$ Cúpula revelaram, até então, um amadurecimento de uma visão comum do BRICS a respeito dos temas chave da situação internacional contemporânea. Algo de grande transcendência na fase atual marcada por renhida luta entre as potencias tradicionais, que buscam - numa contratendência - reverter a perda de posição relativa em relação à ascensão dos grandes países em desenvolvimento, sobretudo a China. Estes, ao contrário, com sua aliança, buscam maximizar a janela de oportunidades aberta com a transição no quadro geopolítico global. 
Na $6^{\text {a }}$ Cúpula, os BRICS seguiram avançando na construção de esta visão comum em um conjunto de temas sensíveis da agenda global. De grande importância política, foi o posicionamento na Declaração de Fortaleza sobre a situação da Ucrânia, francamente favorável ao fim do conflito, por uma solução pacifica; assim, oposta a tentativa do "ocidente" de isolar a Rússia ${ }^{52}$. Tentativa de isolamento, aliás, que resultou em expressiva diminuição das ambiguidades da política externa russa pós-soviética, tornando os BRICS uma prioridade para Moscou e solidificando sua aliança geopolítica com a China.

Especificamente para o Brasil, podemos dizer que a $6^{\text {a }}$ Cúpula dos BRICS, por seus resultados e pelas perspectivas que apontam, foi uma das mais significativa iniciativa geopolítica brasileira, pelo menos na história recente, tendo em vistas suas consequências neste grande jogo da disputa por espaço e poder na "ordem" internacional contemporânea ${ }^{53}$.

A Cúpula de Fortaleza, por seus resultados, desqualifica a análise (ou melhor, o desejo) comum entre os think-thanks e analistas dos grandes meios de comunicações dos países centrais, segundo os quais, por sua diversidade cultural e geográfica, os BRICS seriam incapazes de celebrar substanciais acordos entre si e atuar conjuntamente, com posições comuns quanto aos grandes temas da atual ordem global. Para estes, os conflitos prevaleceriam sobre a cooperação. No entanto, as seis Cúpulas mostram crescente maturidade da aliança.

$\mathrm{Na}$ quadra atual, potencialmente, tornam-se os BRICS uma sólida aliança tática a favor da transição para a multipolaridade, no que corresponde ao interesse nacional de seus integrantes na aspiração por mudança da posição relativa destes países no sistema internacional. Com o NDB e o CRA, ademais, os BRICS passam a ter "dentes" adicionais para sustentar essa ascensão. O ceticismo e a má vontade do ocidente com os BRICS -

${ }^{52}$ Recorde-se que em março de 2014, na votação da ONU de hipócrita resolução patrocinada pelos países da OTAN, pela "integridade territorial da Ucrânia" (sic), num gesto político de grande relevância, os quatro BICS se abstiveram conjuntamente. A Declaração de Fortaleza apresentou a primeira opinião comum dos BRICS quanto a crise na Ucrânia. No ponto 44, lê-se que "Expressamos nossa profunda preocupação com a situação na Ucrânia. Clamamos por um diálogo abrangente, pelo declínio das tensões no conflito e pela moderação de todos os atores envolvidos, com vistas a encontrar solução política pacífica, em plena conformidade com a Carta das Nações Unidas e com direitos humanos e liberdades fundamentais universalmente reconhecidos".

53 Outra ação geopolítica destacada do Brasil foi em 2010, quando da articulação diplomática entre Brasil, Turquia e Irã que resultou na assinatura da Declaração de Teerã sobre o dossiê nuclear iraniano, que provocou, naquele momento, a entrada destes novos atores no cenário geoestratégico global, gerando contundente reação do status quo. 
parte ideológica da luta geopolítica em curso no mundo - se contradiz com os fatos, já que essa coalizão vai demonstrando crescente capacidade de coesionar-se tendo em vista convergirem os interesses nacionais de cada um de seus integrantes.

Este ensaio, que busca relacionar o momento e os desafios atuais do BRICS vis-a-vis o cenário geopolítico contemporâneo, se compõe de três partes.

Dividiremos esta sessão nas seguintes partes: na primeira delas, buscaremos avaliar os resultados de Fortaleza em sua relação com as grandes incertezas e cenário de disputa geopolítica que caracterizam a atual transição no sistema internacional. Uma segunda parte buscará oferecer uma interpretação do BRICS, observando suas potencialidades e seus limites. Buscaremos apresentar alguns marcos teóricos pelos quais podemos ler os BRICS. A terceira parte se propõe a avaliar como o BRICS podem ser lido tendo em vista a aspiração brasileira de ascender a condição de potência global, bem como a repercussão da participação na coalizão para o entorno geográfico-estratégico do país. Por fim, apresentaremos algumas conclusões, marcadamente buscando observar desafios após a histórica $6^{\text {a }}$ Cúpula de Fortaleza.

\section{1 - A reunião de Fortaleza e as incertezas na transição no sistema internacional}

À época, a reunião de Fortaleza chegou a ser interpretada como um ensaio de novo Bretton Woods. Exageros a parte, entretanto, foi correta a interpretação da transcendental decisão, expressa nas palavras do presidente sul-africano, Jacob Zuma, para quem a reunião foi "a historic and seminal moment which saw for the first time since the postBretton Woods Institutions era, the creation of a new and unique financing initiative" ${ }^{\text {. }}$.

O Banco (NDB) surgira com capital autorizado de US\$ 100 bilhões e capital inicial subscrito de US\$ 50 bilhões, com contribuições por igual dos cinco sócios ${ }^{55}$. Mas a medida em que se consolide, diz um analista, "o Banco vai atrair outros depósitos e

\footnotetext{
54 "Um momento histórico e seminal, que viu pela primeira vez desde as instituições de Bretton Woods, a criação de uma nova e única iniciativa de financiamento" (tradução livre). Ver http://www.thepresidency.gov.za/pebble.asp?relid=17711

${ }^{55}$ Ao contrário das instituições de Bretton Woods, o NDB surge com uma governança rigorosamente equivalente em termos de distribuição de poder entre seus cinco sócios fundadores. É altamente questionável, portanto, a interpretação de certos analistas ocidentais, que o Banco seria "instrumento da expansão chinesa".
} 
crescer dez ou vinte vezes" ${ }^{\text {}}$. Isso se explica pela capacidade de alavancagem própria de uma instituição financeira desta natureza e da possibilidade de atrair capitas de fundos diversos. A China, por exemplo, com alta liquidez, poderá no Banco encontrar alternativa de rentabilidade para seus recursos.

O Fundo, por sua vez, "um mini-FMI", com caixa comum de US\$ 100 bilhões, é importante seguro contra crises futuras no balanço de pagamentos, ameaça presente sobretudo persistindo as manobra monetária dos países ricos, sobretudo dos Estados Unidos, que diante da retirada dos estímulos em resposta a crise, tem tomados medidas que geram (uma ainda moderada) saída de divisas nas economias emergentes - uma "fuga para liquidez", nas palavras de Luis Gonzaga Belluzzo ${ }^{57}$. Poderá ser importante instrumento para a proteção das moedas nacionais e a própria estabilidade econômica dos países BRICS.

Do ponto de vista geopolítico, as iniciativas atuam diretamente na relativa diminuição da influência dos Estados Unidos e da União Europeia - via instituições que controlam com mão de ferro, FMI e Banco Mundial - junto aos países em desenvolvimento, criando alternativas de financiamento despojadas das condicionalidades política e econômica aviltantes destas instituições tradicionais - é certo, mais draconianas para uns que para outros. Por exemplo, a Ucrânia, com a instalação do governo pró-ocidente em Kiev, teve aprovado em tempo recorde empréstimo de US\$ 18 bilhões.

O fato é que as funções precípuas do Banco Mundial e do FMI - que conforme concebido 70 anos atrás em Bretton Woods, é de "financiar o desenvolvimento" e "conter crises no balanço de pagamentos" - são cada vez mais de difícil execução, tendo em vista sua dimensão insuficiente diante das necessidades do mundo atual, caracterizado pela enorme carência de recursos para infraestrutura e financiamento do desenvolvimento no mundo, sobretudo pelos países em desenvolvimento - a Unctad estima essa demanda em US\$ 1 trilhão, apenas para infraestrutura. Nesse sentido é que surgem vigorosas alternativas, como se viu anteriormente com a proposta chinesa do One Belt, One Road, como vimos anteriormente.

\footnotetext{
${ }^{56}$ Michael Wong, professor da City University de Hong Kong, em entrevista a BBC Brasil, 15/07/2014.

57 "Em um mundo de inevitáveis colisões". Carta Capital, 23/07/14.
} 
O surgimento do NDB e do CRA decorrem antes que nada da enorme resistência dos países do estabilishment em ceder poder e reformar os organismos financeiros internacionais - fato expresso sem meias palavras no ponto 18 da Declaração de Fortaleza. Mesmo diante da enorme carência por recursos no mundo, os países do G-7 resistem em ampliar o papel de instituições como o Banco Mundial ao mesmo tempo em que não aceitam diminuir seu controle, de modo a expressar o real peso econômico de cada país atualmente, muito diferente do pós-guerra. A China, por exemplo, possui menos votos no FMI que a cadeira correspondente aos países Benelux (Bélgica, Holanda e Luxemburgo). O G-7 possui 43\% dos votos no FMI; os BRICS, em seu conjunto, 10,3\%, a despeito de representarem cerca de $1 / 4$ do PIB mundial.

Vale lembrar que os BRICS têm aportado significativas quantias de recursos ao FMI no pós-crise, tornando-se, ineditamente credores da instituição. Como lembra Paulo Nogueira Batista Júnior, então na condição de diretor do FMI indicado pelo governo brasileiro, em 2012, "a China anunciou US\$ 43 bilhões adicionais (ao FMI); o Brasil, a Rússia e a Índia anunciaram US\$ 10 bilhões cada; África do Sul entrará com US\$ 2 bilhões. Na rodada anterior de levantamento de empréstimos para o FMI em 2009, os BRIC entraram com o equivalente a US\$ 92 bilhões - a China com US\$ 50 bilhões, Brasil, Rússia e Índia com US\$ 14 bilhões cada" ${ }^{\text {" }}$. Batista Junior, a partir de 2015 se tornaria o vice presidente do Banco dos BRICS.

A atitude reformista do BRICS em relação às instituições financeiras internacionais tem relação com o fato, como diz Hurrell (2009, p. 27), de estas serem efetivamente espaços de poder, capazes até mesmo de "constranger os mais poderosos", dada a capacidade de órgãos como o FMI e o Banco Mundial de definirem padrões de política econômica para os países. Invariavelmente estes padrões atendem a interesses nacionais dos países que os dominam - no caso, desde sua criação no pós-guerra, os Estados Unidos e a União Europeia, "donos" das cotas que asseguram seu controle.

O NDB aparece como atrativa alternativa para a alocação de liquidez e das cada vez mais vultosas reservas em divisas dos grandes países emergentes, trocando os títulos "seguros" como os treasuries (títulos do Tesouro norte-americano), de baixa remuneração, por investimentos nas potencialmente rentáveis obras de infraestrutura na América Latina e

58 "Os BRICS no FMl e no G-20", dezembro de 2012. 
na África, com garantias em operações governo-a-governo. Por isso mesmo, como observou, quando do surgimento da instituição, artigo do Financial Times, "marcará uma mudança significativa na arquitetura do financiamento internacional do desenvolvimento"59.

No caso da China, o país desde 2009 vem anunciando uma estratégia de reduzir a exposição - e portanto a vulnerabilidade - de manter grande parte de suas reservas aplicadas em títulos norte-americanos ${ }^{60}$. Aliás, o NDB cabe como luva na estratégia chinesa de diversificação monetária e na busca da internacionalização do renminbi.

Assim, o surgimento do NDB e a alocação de parte das reservas no CRA podem ser lidos como movimentos de diminuição da exposição dos países BRICS em relação ao dólar. Há que perguntar-se quais serão suas consequências em médio e longo prazo para a hegemonia do dólar no sistema financeiro internacional, um dos fatores chave para a hegemonia global norte-americana.

Na medida em que isso se manifeste com clareza, há riscos de recrudescimento da guerra financeira do G-7 contra os BRICS. Afinal, a governança financeira internacional é cada vez mais marcada por impactos geopolíticos, derivados do fato de que no próprio âmbito do G-20 se cristalizam cada vez mais nitidamente dois blocos de força: de um lado, o G7 - uma coalizão de países do velho status quo liberal, cujo caráter foi reafirmado com o expurgo da Rússia após a Crimeia - e os BRICS e seus aliados. Jim O’Neill, em artigo de balanço da $6^{a}$ Cúpula no The Telegraph, falava de "duas facções" em disputa no G$20^{61}$. Do desfecho desta luta, em boa medida, resultará a arquitetura financeira internacional do século XXI.

Uma medida promissora no sentido de impactar sobre hegemonia do dólar são a crescente utilização de moedas nacionais nas relações entre os países, traves de acordos de trocas de moedas (swaps) e outros mecanismos semelhantes.

\footnotetext{
${ }^{59}$ Segundo a economista da Universidade de Columbia, Stephany Griffth-Jones (ver "China vence e será sede do Banco dos BRICS". Folha de São Paulo, 08/06/2014, p. B9).

60 Ver artigo, que teve ampla repercussão à época, de Zhu Xiaochuan, presidente do BC (Banco Popular da China).

61 Ver http://www.telegraph.co.uk/finance/globalbusiness/10991616/The-Brics-have-a-100bn-bank.-Canthe-West-start-taking-them-seriously-now.html
} 
O NDB, ademais do grande potencial financeiro, poderá jogar papel relevante na própria atualização da teoria do desenvolvimento diante dos desafios deste século XXI. Afinal, os países BRICS, para além de suas diferenças, ensaiavam uma proposta de desenvolvimento "não-neoliberal", baseado em investimentos produtivos e em infraestrutura. Rejeitam a "perspectiva neorrentista e de reforma econômica clássica"62.

Atendem assim a tradição desenvolvimentista muito presente na trajetória econômica de cada um dos BRICS e a aquilo que Hurrell (2009, p.38) chama de "forte estatismo que caracteriza todos estes países", isto é, o protagonismo do Estado, ao longo da maior parte da história econômica dos BRICS na condução dos rumos do desenvolvimento.

Vale lembrar que o Banco surgira apoiado no know-how e na expertise de robustos bancos nacionais de desenvolvimento de seus integrantes. É o caso do Brasil, com o BNDES, banco que possuía então dimensões superiores ao próprio Banco Mundial.

Sendo o surgimento do NDB e do CRA movimentos de profundos impactos geopolíticos e geoeconômico, cabe rememorar a manobra estratégica do Brasil que permitiu seu anúncio em Fortaleza. Em relação ao Banco, é amplamente conhecido o fato de que o Brasil foi o único dos cinco países a não pleitear a sede da instituição, exatamente para melhor se posicionar para outro pleito, o de indicar o primeiro presidente da nova instituição. Consta, no entanto, que às vésperas da reunião dos líderes em Fortaleza, um impasse permanecia entre Nova Deli e Beijing pela sede do Banco; foi quando a então presidente Dilma Rousseff orientou que o Brasil cedesse a primeira presidência à Índia, possibilitando assim o desfecho que estabeleceu sua sede em Xangai, e assim, a exitoso resultado da reunião de Fortaleza ${ }^{63}$. Ao fazê-lo, o Brasil também reiterou o compromisso do novo governo indiano com os BRICS. Mas, fundamentalmente, permitiu uma cartada potencialmente decisiva no tabuleiro de xadrez geoeconômico global.

Como disse um analista, numa interessante analogia, os BRICS começam querendo "sentar à mesa", cujo acesso lhes era vedado; em seguida, buscaram "mudar o cardápio".

62 Como então dizia Michael Hudson, em Carta Capital, 23/07/14. Obviamente que a mudança de orientação do governo brasileiro repercutiu nesta posição.

${ }^{63} \mathrm{O}$ acordo dizia que o Brasil presidirá o Conselho de Administração do NDB e terá a próxima presidência após a gestão indiana; a Rússia presidirá o Conselho de Governadores (ministros). 
Diante da impossibilidade, passam a "estabelecer sua própria mesa"64. Este foi o significado original do surgimento dos promissores Banco e Fundo dos BRICS.

2 - Interpretando o BRICS, suas potencialidades, seus limites. Por quais marcos teóricos podemos ler os BRICS?

A aliança entre os cinco países BRICS, antes que nada, pode revelar funcional ao desenvolvimento do projeto nacional de cada um de seus integrantes. Em maior ou menor escala, com maior ou menor nitidez, todos os cinco BRICS, pelo menos num primenro momento - isto é, antes da mudança de orientação brasileira - almejavam "modificar sua posição relativa" no sistema internacional, na "distribuição internacional de poder e riqueza", a partir de fatores como território, recursos e coesão social ${ }^{65}$. Noutras palavras, a aliança entre os BRICS é um instrumento para aumentar a margem de manobra de cada um deles e deles em seu conjunto no sistema internacional ${ }^{66}$.

$\mathrm{Na}$ busca por ascender, os cinco BRICS potencialmente reúnem, em maior ou menor medida, a um só tempo vontade nacional e base objetiva. Nas palavras de Hurrell (2009, p.11) "é fácil para o realista empedernido rir das pretensões vazias de países cujas ambições desmoronam diante de suas limitadas capacidades materiais. Contudo, o poder nas relações internacionais requer propósito e projeto".

Como vimos noutras partes deste trabalho, para se tornar potência, por um lado, não basta a um país vontade nacional, é preciso reunir condições objetivas - atributos clássicos de Poder Nacional, tais como território, população, riqueza, capacidade militar e cientifica -; por outro lado, seria ingênuo pensar que existindo as bases objetivas, naturalmente, por determinismo, um país se tornaria potência no sistema internacional. Ao contrário, um país que tiver condições objetivas mas escassa coesão nacional em torno do objetivo de ascender a condição de potência, invariavelmente retrocederá, inclusive, no limite,

\footnotetext{
${ }^{64}$ Anthony W. Pereira, do King's College de Londres (The BRICS Post, 15/07/14).

65 Como argumenta, por exemplo, "Poder, geopolítica e desenvolvimento", de José Luis Fiori, Valor Econômico, 26/06/2013.

${ }^{66}$ Esta foi a base de nossa argumentação em "El rol geopolítico de los BRICS: una vision brasileña", na I Conferencia de Estudos Estratégicos, em Havana, Cuba, outubro de 2013.
} 
concedendo no todo ou em parte seus atributos de poder a outros povos que possuam projeto de nação mais bem delineado.

No que diz respeito ao primeiro aspecto, é essencial observar que a aliança entre os países BRICS tem uma base objetiva, não é produto de definição aleatória. Como se vê no quadro abaixo, se fizermos um recorte a partir dos fatores território, população e tamanho da economia, encontraremos os quatro BRICs originais e os Estados Unidos.

A incorporação da África do Sul, decidida na terceira Cúpula, realizada em Sanya (China) dá a clara dimensão geopolítica da aliança, a começar da condição geográfica do país africano como ponto de contato entre os oceanos Atlântico e Índico. Ademais, incorporara um país relativamente estável do continente africano, dirigido por uma coalizão progressista liderada pelo Congresso Nacional Africano (ANC) e líder da União Africana - a sul-africana Nkosazana Dlamini-Zuma, ex-esposa do presidente Zuma, é a secretária geral da UA desde 2012.

Os cinco BRICS reúnem poder combinado extraordinário: dois membros "não ocidentais" do Conselho de Segurança das Nações Unidas, três potências nuclearmente armadas, além de serem países com forte base de recursos naturais, capacidades industriais, parques científicos, tecnológicos e de inovação em áreas, em geral, complementares e capacidade de produção de alimentos.

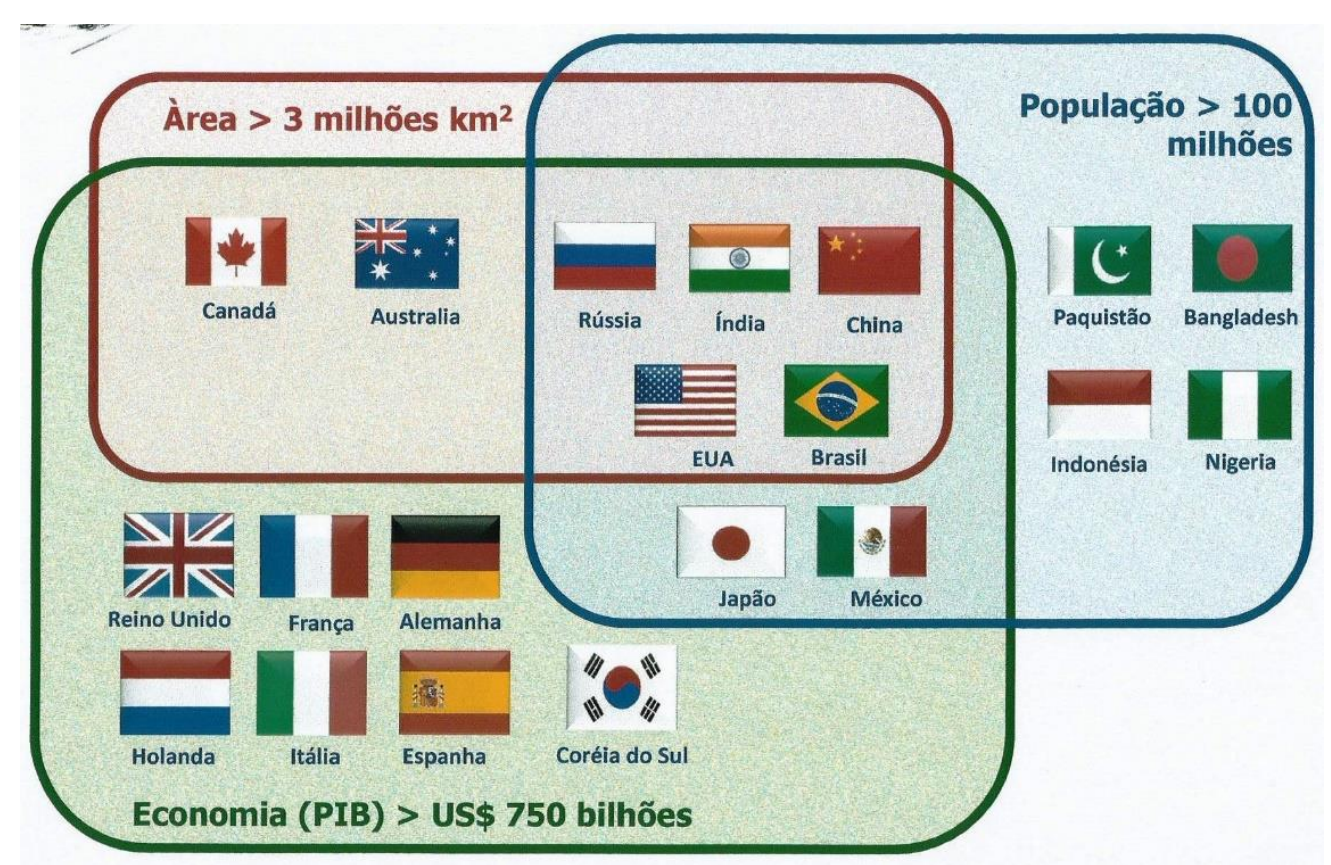


Assim, a aliança entre os BRICS deve ser observada mais por fatores estruturais que conjunturais. Por exemplo, são países que reúnem potencial de dinamismo econômico superior aos atuais países centrais, a começar pela própria dinâmica intrínseca ao capitalismo relativa ao desenvolvimento desigual. A própria capacidade revelada na resistência à primeira fase da crise internacional eclodida em 2008, é demonstrativa deste fator. Contudo, dada as proporções que a crise revelou, seria pouco realista desconsiderar que os BRICS não seriam impactados em suas taxas de crescimento.

Mas fatores como o extraordinário espaço de crescimento dos mercados internos de massas de cada um dos BRICS, num contexto de política mais ou menos redistribuitivas, que permitiram importante mobilidade social, foram e serão importantes fatores de dinamismo econômico destes países. Da mesma forma, são países, que por sua própria dimensão, tem na presença do Estado - "capitalismo de Estado" -, por meio de empresas estatais e mecanismos de planejamento econômico, fator de grande importância.

A despeito de ter sido sintetizado por um estudo econométrico de um banco de investimentos ${ }^{67}$, os BRICs se caracterizam por sua extraordinária potencialidade; todos são países portadores de futuro - muito para além de uma diminuição do crescimento econômico derivado dos efeitos conjunturais da crise. Ademais, é recorrente na teoria geopolítica - aqui não há qualquer originalidade do Sr. O’Neill -, a centralidade do papel dos megaestados ou "países-baleia". São países cujos fatores combinados revelam extraordinário potencial.

Como recorda Ricupero (FUNAG, 2012), "essa inovação conceitual (o BRICS) foi, na verdade, criada por George Kennan, e não por essa figura menor de um banco de investimentos". Ricupero se refere ao conceito de monster countries, proposta pelo geopolítico e diplomata norte-americano, a respeito de países que combinam ao mesmo tempo "uma extensão continental e grande população"68. Para Kennan, os cinco países monstro eram os EUA, a então União Soviética, a China, a Índia e o Brasil. Vale lembrar - retomaremos o tema mais a frente - que Kennan é também conhecido por desenvolver

${ }_{67}$ Refiro-me a Building Better Global Economic BRICs (2001), disponível em http://www.goldmansachs.com/our-thinking/archive/archive-pdfs/build-better-brics.pdf

${ }^{68}$ Ideia apresentada em Around the Cragged Hill: A Personal and Political Philosophy, cuja primeira edição é de 1993. 
a teoria das fímbrias ou rimland de Nicholas Spykman, no que viria a ser conhecida como teoria da contenção ou Doutrina Truman - isto é, a ideia de movimentos geoestratégicos visando limitar o poder da URSS aos limites do heartland.

O que observamos até aqui mostra como o BRICS tem fundamento em conceitos e análises geopolítica e geoestratégicas muito mais complexas do que o relatório para investidores do Sr. O’Neill.

Outro aspecto teórico essencial a considerar relaciona-se a forma pela qual os países BRICS assumem sua postura reformista, pela qual buscam “demandar a revisão da ordem estabelecida e de suas normas dominantes de maneira a refletir seus próprios interesses, preocupações e valores" (Hurrell, 2009, p.11).

Sendo o BRICS originalmente uma aliança "anti status quo", qual o meio que estes países utilizam para efetivar seus propósitos?

Podemos encontrar na literatura conceitos importantes para responder esta questão. Ideias como balança de poder, proposta pela escola realista ou de bandwagoning são uteis para compreender o comportamento dos países em geral e do BRICS, especificamente.

Na balança de poder, Waltz (2000) por exemplo, diz que os Estados responderão ao poder concentrado com vários tipos de balanceamento de poder, unindo forças contra os mais poderosos $^{69}$. Por bandwagoning ${ }^{70}$, compreende-se ato oposto, ou seja, de aliar-se ao país ou coalizão mais forte, numa espécie de acomodação pragmática em relação ao hegemon. No caso, do BRICS, concordamos com Hurrell (2009, p.34-35) e outros autores ${ }^{71}$, que o mais adequado será considerar que os BRICS adotam uma espécie de balanceamento brando. Segundo o autor, o balanceamento brando "não envolve tentativas diretas de confrontar ou constranger o país dominante por meio de alianças militares (balanceamento externo) ou mobilização militar (balanceamento interno)”. Ao contrário, diz ele, "envolve outras formas de cooperação: ententes, entendimentos informais,

69 Originalmente, encontramos o conceito de "Balança de Poder" em Spykman, Nicholas. America's Strategy in World Politics: The United States and the Balance of Power, New York: Harcourt, Brace and Co., 1942, 447.

70 Termo atribuído ao cientista político Stephan Van Evera (Hurrell, 2009, p.17)

${ }^{71}$ Em Hurrell encontra-se referencias, sobre este conceito, a T. V. Paul e Robert A. Pape. 
exercícios cooperativos ad hoc ou colaboração em instituições internacionais ou regionais". Continua o autor argumentando que "o propósito destas formas cooperativas é complicar e aumentar os custos das políticas norte-americanas em instituições internacionais (especialmente negando legitimidade a elas)", utilizando-se assim de “mecanismos não militares” para atingir seus propósitos reformistas.

Poderá se argumentar que com a criação de instrumento que atuam diretamente sobre a ordem econômica e financeira internacional - caso do Banco e do Fundo do BRICS -, os cinco grandes países intervém de uma forma nada branda em relação a alteração do status quo, pelomenos quanto a ordem geoeconômica. De toda forma, para além da possibilidade de desenvolver cooperação estratégica - hoje apenas embrionária ${ }^{72}-$, efetivamente a transição sui generis na atual ordem internacional precede a manu militari.

Uma última questão nesta chave de interpretar o BRICS é compreender as singularidades de cada um de seus integrantes. Observe-se que estas diferenças, naturais em se tratando de mega países, são amplificadas pelo mainstream na campanha por desacreditar o BRICS. Diferenças, contudo, que não se revelam obstáculos tendo em vista preponderar a convergência de interesses na ascensão no sistema internacional, conforme temos argumentado nesta sessão.

Três do BRICS são civilizações milenares: a russa, a hindu e a chinesa. Destas, historicamente, duas já experimentaram condição de superpotência: a Rússia, como vértice da União Soviética, e a China como o poderoso Império do Meio até o início do século de humilhação em 1850. Nesse sentido podemos denominar as intenções de (re)ascensão de Rússia e China como intentos restauracionistas de condição já vista no passado.

Ao lado das três civilizações milenares, junta-se uma nova civilização, a brasileira, constituída muito mais recentemente, mas com características singulares que lhe outorgam enormes potencialidades. Poderíamos falar aqui não apenas de potencialidades objetivas do Brasil, mas das extraordinárias potencialidades civilizatórias do Brasil fruto de sua formação social original, da constituição de um povo-novo, amalgamado pela confluência de sua três vertentes constitutivas - fato que exploraremos no próximo capitulo.

\footnotetext{
${ }^{72}$ Aqui nos referimos as reuniões relativamente regulares dos National Security Advisors dos BRICS
} 
O quinto BRICS, os sul-africanos não configuram uma civilização, num sentido antropológico mais complexo, tendo em vista sua marcada cisão étnica e até tribal. Entretanto, sua presença na coalizão a fortalece, como dissemos, por razões geopolíticas e geoestratégicas, tendo em vista ser o vértice da integração africana e a zona geográfica (cone austral africano) de confluência entre o Atlântico e o Pacífico.

Passemos a seguir a identificar algumas das razões geopolítica e estratégicas de cada um dos RICS. Mais a frente dedicaremos um sessão própria a discutir o caso brasileiro. Nossa motivação aqui é retomar o argumento de que o BRICS é essencialmente uma aliança entre países com interesse em comum. Trata-se de uma aliança tática: os BRICS combinam sua força, como dissemos, para acelerar uma transição na situação internacional que favoreça o projeto nacional de cada um de seus integrantes, reunindo condições mais favoráveis ao curso de seu desenvolvimento. Os três gigantes da massa territorial euro-asiática - Rússia, Índia e China -, em especial, historicamente equilibramse entre cooperação e conflito; no contexto desde início do século XXI, certamente o fator cooperação se sobrepõe ao fator conflito.

Rússia e China, em especial, possuem pensamento geopolítico denso e estruturado. Índia e Brasil, embora mais recentes, idem. A África do Sul, vai estruturando sua visão nacional.

A Rússia herda do czarismo e sobretudo da geopolítica soviética ao longo de sete décadas no século XX, longa tradição de pensamento estratégico. Em grande medida, com Putin, essa tradição é retomada na recuperação do Eurasianismo.

Baseada nesta tradição, ocorre uma grande novidade estratégica contemporânea representada pela nova postura russa, que embora vinha sendo ensaiada há alguns anos e agora, sob a segunda presidência de Putin toma forma nítida. Crescentemente ameaçada em seu core interest - que inclui sua própria integridade territorial e manutenção da zona de influência geoestratégica -, Moscou dá sinais de claro abandono da tradicional ambiguidade geopolítica que a tem caracterizado desde o fim da URSS, equilibrando-se entre a necessária autonomia que deve ter um grande país e a aliança com o ocidente, na qual a cooptação ao G7, alargado para G8 é símbolo.

O primeiro grande lance representativo da nova postura russa foi a ação que garantiu as bases para uma virada de jogo na guerra da Síria, em outubro último, impedindo, por ousada manobra diplomática, a consumação da intervenção da OTAN a partir da 
manipulação grosseira a respeito do uso de armas químicas supostamente pelo governo de Bashar Al-Assad. Mais recentemente, novo lance russo, este ainda mais ousado, foi o estabelecimento de linha vermelha a repeito de sua integridade territorial, diante da ação europeia/ocidental de cooptação da Ucrânia - Kiev é um berço da nacionalidade russa. A anexação da Crimeia, pois, foi uma mensagem clara de que o limite de Moscou é a ameaça a sua integridade territorial e às minorias russas espalhadas em seus limites fronteiriços.

A Cúpula de Fortaleza, pois, ocorreu neste contexto, como vimos, de nova postura geopolítica russa ao mesmo tempo em que há um recrudescimento das pressões geoestratégicas direcionadas à China, no sentido de pôr este país na defensiva em seu próprio mar territorial. Nesta moldura geopolítica que deve ser lido a recente visita, em maio último, de Vladimir Putin a Beijing e a assinatura um pacto energético de 30 anos para o fornecimento de gás russo a China - driblando a tentativa de isolamento russo pelo ocidente. Uma aliança entre dois grandes países, membros do Conselho de Segurança e grandes potências nucleares - aliança que, fortalecida, tem efeitos diretos sobre a solidificação da aliança dos BRICS.

Assim pode ser lida, para a Rússia, a reunião de Fortaleza. Para Moscou esta teve um sentido estratégico chave, sobretudo tendo em vista que, diante do retorno do protagonismo de Moscou no cenário internacional, recrudescem movimentos das potencias estabelecidas para constrangê-lo em seu próprio entorno geográfico - vide o avanço da OTAN sobre a Ucrânia. A presença do presidente Putin em Fortaleza foi sua primeira presença em foro multilateral pós-Crimeia e o segundo movimento expressivo de buscar romper a tentativa de isolamento - o primeiro foi a visita de maio à Beijing, ocasião em que assinou o citado acordo energético.

Na ocasião, Obama, seguiu sua ofensiva antirussa e numa provocação (extensiva ao país anfitrião da Cúpula), anunciou novas rodadas de sanções estando o presidente Putin em Brasília. A derrubada do avião da Malaysia Airlines no leste da Ucrânia - dois dias depois da reunião de Fortaleza e aproximadamente no mesmo momento em que o avião de Putin retornava a Moscou - somou-se a essa ofensiva, numa nítida operação, que em termos militares se pode denominar como "operação de bandeira falsa"73.

${ }^{73}$ False flag em inglês. São operações militares ou de inteligência que aparentam ser realizadas pelo inimigo de modo a tirar partido das consequências resultantes. Que interesse teriam os rebeldes ucranianos 
Dias depois, foi a vez de Putin anunciar a retaliação: sendo o $5^{\circ}$ maior importador de produtos agropecuários, Moscou anunciou o cancelamento das compras nos mercados europeu e norte-americano - apenas a União Europeia exportou US\$ 13,8 bilhões em produtos agrícolas á Rússia em 2013. Num gesto importante, deu sinais que buscará no mercado brasileiro parte importante destes produtos. Também a indústria de Defesa russa, objeto de pesadas sanções ocidentais, poderá buscar o mesmo caminho junto aos BRICS.

Para a China, a participação no BRICS aporta ao interesse central da política externa chinesa contemporânea: "a busca ativa de um entorno internacional pacífico em benefício de seu próprio desenvolvimento", nas palavras do presidente Xi Jinping ${ }^{74}$. Ademais, a aliança aporta à aspiração deste país em adensar sua presença no cenário internacional e de aumentar sua diversificação financeira. A relação com grandes países detentores de matérias-primas também serve ao interesse chinês de garantir o fluxo regular destes bens ao país, sustentando o desenvolvimento chinês. Neste caso, além da relação com Brasil, Rússia e África do Sul - grandes detentores de matérias-primas - a aliança facilita o acesso ao entorno destes países, especialmente à América Latina e Caribe e a África ${ }^{75}$.

Cabe destacar - a despeito da sinofobia propagada por alguns think-thanks conservadores do Ocidente -, a singularidade confuciana da geopolítica chinesa. Como propõe Torres (2014),

La narrativa "Confucio-menciana" parte de las más ancestrales raíces, en las que se interpretaba que China era el centro cultural universal. Este centrodebía ser respetado y asimilado por los pueblos de los que se rodeaba, a los que debería regir por su jerarquía y administrar en armonía. En este orden no se veía necesario el conflicto, que se consideraba como una aberración, consecuencia de un relajamiento moral o error de mando. Esta narrativa, que se encuentra profundamente arraigada en el discurso actual de la geopolítica de China, sufrió el más grave de sus reveses cuando las potencias occidentales del S.XIX, embebidas de los primeros conceptos geopolíticos, la convirtieron casi repentinamente en un territorio colonial.

em atacar um avião civil de passageiros? Ao governo direitista de Kiev, ao contrário, surgiu uma oportunidade para liquidar com força militar extrema o movimento separatista.

${ }^{74}$ Entrevista a quatro meios de imprensa da América Latina, em 14 de julho de 2014.

75 Ainda que, vale dizer, a primarização nesta relação é objeto de crescente preocupação, por exemplo, dos países latino-americanos. É o caso do Brasil, que em 2013, teve nas commodities $87 \%$ de suas vendas à China enquanto de suas importações deste país, $60 \%$ foram de produtos industrializados (Carta Capital, 23/07/14). 
A influência da formação social no pensamento geopolítico é tema que deve ser considerado como determinante para compreender a visão de mundo de um determinado Estado.

Também no caso indiano, há que considerar a influência do pensamento de Estado para considerar as atitudes e posições tradicionais do país. Assim, a despeito do novo governo de direita, eleito em maio último, os primeiros seis meses do novo governo mostram uma linha de relativa continuidade em política externa.

A reunião de Fortaleza representou a primeira viagem internacional do então recém empossado primeiro ministro, Narendra Modi. É expressivo constatar que o primeiro encontro de Modi com seus dois grandes vizinhos - Rússia e China - tenha se dado em solo brasileiro - a partir do qual pactuou adensamento da presença indiana na Organização de Cooperação de Xangai, aliança na disputa geopolítica no heartland do mundo.

As intervenções de Modi reiteraram compromisso da Índia com os BRICS, reforçada pelo fato do primeiro-ministro voltar a Nova Delhi com a primeira presidência do NDB - vale lembrar que a ideia surgiu na $4^{\text {a }}$ Cúpula, realizada na Índia em 2012.

A África do Sul, por sua vez, tem especial interesse de consolidar os compromissos que ela pilotou na Cúpula de Durban (2013), relativo ao apoio dos BRICS à integração africana através do financiamento da infraestrutura: o país ocupa a presidência da União Africana. Tendo em vista este objetivo, Zuma volta de Fortaleza com um escritório do NDB, que será inaugurado concomitantemente a sede de Xangai, renovando compromissos com a prioridade do governo de Tshwane.

A mudança de governo no Brasil afetou, esperamos que por um breve período, o papel protagonista que o país teve nos BRICS. Nesse sentido, a deposição de Dilma Rousseff pode ser lida inclusive pela chave de um relativo enfraquecimento dos BRICS. O pedido de adesão brasileira a OCDE (Organização para a Cooperação e Desenvolvimento Econômico), o "clube dos ricos", como é conhecido, simboliza essa mudança de orientação brasileira. De conjunto, esta mudança de orientação é reveladora de importante limitação do Brasil. Afinal, revela o país ter baixo consenso sobre sua Grande Estratégia. Uma limitação determinante para o projeto nacional brasileiro. 
Com esta leitura da geopolítica dos BRICS concluímos este terceiro capitulo. As três sessões apresentadas nos permitem observar um panorama amplo da conjuntura internacional, sobretudo em seus aspectos sistêmicos, que permitem interpretar o ambiente e o contexto sob o qual o projeto nacional brasileiro - sua Grande Estratégia, tendo em vista agregar Poder Nacional - atuará.

A seguir, no capitulo IV, discutiremos mais a frente um problema que aqui já bordejamos, relativo ao problema da coesão nacional. 


\section{Capítulo IV}

\section{Questão nacional, identidade brasílica e coesão nacional como problema estratégico}

Todo reino dividido contra si mesmo é devastado, e toda cidade ou casa, dividida contra si mesmo não subsistirá

(Mateus 12,25)

O problema da coesão nacional, como vimos no capitulo I, é tema recorrente na aferição dos elementos de Poder Nacional. A questão da identidade nacional, por sua vez, também é tema clássico da geopolítica clássica - universal - e da geopolítica brasileira.

Nesta sessão, nos propomos a percorrer este debate, tratando da questão nacional como atributo constitutivo essencial do Poder Nacional, nas formas que definem os clássicos.

No trabalho contemporâneo já clássico Geografia Política e Geopolítica - discursos sobre o território e o Poder (2008, com primeira edição de 1991), Wanderley Messias da Costa dedica importante sessão de seu capitulo seis, a discutir a questão das "Nações e nacionalidades" como "um debate recorrente". No texto, se diz que "a evolução da geografia política demonstra bem o quanto essa questão é recorrente na preocupação dos seus autores". Por exemplo, "para Ratzel, o problema nacional alemão era primordial", assim, como "os estudos dedicados ao quadro europeu do pós-guerra, como os de Brunhes e Vallaux, Bowman e Hartshorne, entre outros (...)" (COSTA, 2008, p.287).

Na geopolítica brasileira não é diferente.

Podemos partir da identificação do problema nacional nos estudos estratégicos a partir da visão, que mencionamos na sessão anterior, sobre a dupla missão das Forças Armadas num país com as características do Brasil: país de formação relativamente recente, com tarefas geohistóricas e geoeconômicas todavia pendentes, notadamente àquelas ligadas a definitiva integração nacional.

A ideia da dupla missão vem de longe no pensamento estratégico nacional. Essencialmente, diz respeito à conjunção da tarefas clássicas de um Força Armada - a 
missão de defesa da soberania e da integridade nacional contra ameaças externas - aos desafios da construção nacional. Como dissemos anteriormente, esta visão vem de longe; pode ser localizada na própria base de ideias que emergiu e sustentou-se com a Revolução de 1930.

Gilberto Freyre, o maior interprete do Brasil, tratou do tema, em janeiro de 1942, em magistral prefácio a Introdução à Geografia das Comunicações Brasileiras, do Coronel Mário Travassos, um dos fundadores da geopolítica brasileira contemporânea. Dizia Freyre que,

"Ao Exército toca, no Brasil, a parte mais importante da tarefa enorme de autocolonização que nos falta realizar. Ao Exército cabe, entre nós, concorrer para a administração de áreas particularmente necessitadas de governos de ação mais livremente construtora na fase, que ainda atravessamos, de incorporação, integração ou reintegração dessas áreas ao sistema brasileiro de cultura. Sistema de características apenas esboçados e que representa a vitória esquemática mas já esplendida da primeira civilização moderna a vingar nos trópicos. E essa vitória difícil, nós corremos o risco de perde-la se diminuir o nosso esforço de solidificação de valores que só hoje vão se tornando claros. Claros aos olhos dos estrangeiros - por tanto tempo descrentes da capacidade dos povos mestiços (como é, na sua maioria, o nosso) para se elevarem, em terras tropicais, a realizações superiores. Claros aos olhos dos próprios brasileiros, tantos deles saotomés intransigentes, não querendo acreditar nunca na realidade de um tipo de civilização com tantos traços originais e superiores como a luso-brasileira".

Pouco depois, em conferencia na ECEME (Escola de Comando e Estado Maior do Exército), em 1948, Gilberto Freyre, em texto denominado A Nação e o Exército, discute conceito chave, que aparece em outras de suas obras, relativas ao benefícios da miscigenação dos brasileiros para formar um equilíbrio de antagonismos (FREYRE, 1949, p. 14) que atua diretamente sobre a coesão nacional.

O problema da identidade nacional, da unicidade do povo pode configurar-se em problema geopolítica central num quadro de profundas divisões entre etnias que coloquem em questão o próprio rumo e sentido do projeto nacional.

Samuel Pinheiro Guimaraes, em seu Desafios Brasileiros na era dos gigantes, argumenta que,

"A sociedade brasileira caracteriza-se por uma crônica vulnerabilidade externa com facetas econômica, política, tecnológica, militar e ideológica. A mais importante, pois influencia todas as políticas e atitudes do Estado e da sociedade brasileira (empresas, associações, Partidos, ONGs, igrejas, indivíduos, etc.) e agrava as outras facetas da vulnerabilidade externa é a de natureza ideológica. É ela que, por meio de diversos mecanismos, mantem e aprofunda a consciência colonizada não só das elites dirigentes tradicionais como até de segmentos de oposições políticas, intelectuais, econômicas e burocráticas. A consciência colonizada expressa-se em uma atitude moral timorata e subserviente que alimenta sentimento de impotência da população, ao atribuir as mazelas 
brasileiras à escassez de poder do Brasil, à incompetência brasileira, ao nosso capipirismo, ao arcaísmo social, à xenofobia, enfim, à nossa inferioridade como sociedade" (GUIMARAES, 2006, p.225-226).

O problema exposto pelo Embaixador Samuel, quanto ao que ele denominou vulnerabilidade ideológica brasileira, se acentua em momentos de crise, quando a autoestima do povo, de consciência do sentido e do projeto de Nação, reflui. É o momento que vivemos atualmente quando da redação desta Tese. Superar este estado de coisas constitui problema geopolítico básico para a solidez e a coesão dos brasileiros em torno da edificação da grandeza nacional.

Por que o problema da identidade nacional constitui-se num problema geopolítico fundamental? Nas palavras de um dos maiores interpretes da formação social brasileira, Darcy Ribeiro, em seu O Povo Brasileiro (2006), ao analisar o fato das origens do povo brasileiro ter se constituído a partir de três afluentes - o elemento indígena, o português e o negro -, observa,

"A confluência de tantas e tão variadas matrizes formadoras poderia ter resultado numa sociedade multiétnica, dilacerada pela oposição de componentes diferenciados e imiscíveis. Ocorreu justamente o contrário, uma vez que, apesar de sobreviverem na fisionomia somática e no espirito dos brasileiros os signos de sua múltipla ancestralidade, não se diferenciam em antagônicas minorias raciais, culturais ou regionais, vinculadas a lealdades étnicas própria e disputantes de autonomia frente à nação. As únicas exceções são algumas microetnias tribais que sobrevivem como ilhas, cercadas pela população brasileira [...e] qualquer que seja seu destino, já não podem afetar a macroetnia em que estão contida" (RIBEIRO, 2006, p.18).

Assim, continua Darcy,

"[...] os brasileiros se sabem, se sentem e se comportam como uma só gente, pertencente a uma mesma etnia. Vale dizer, uma entidade nacional distinta de quantas haja, que fala uma mesma língua, só diferenciada por sotaques regionais, menos remarcado que os dialetos de Portugal [...] Mais que uma simples etnia, porém, o Brasil é uma etnia nacional, um povo-nação, assentado num território próprio e enquadrado dentro de um mesmo Estado para nele viver seu destino. Ao contrário da Espanha, na Europa, ou da Guatemala, na América, por exemplo, que são sociedade multiétnicas regidas por Estados unitários e, por isso mesmo, dilaceradas por conflitos interétnicos, os brasileiros se integram em uma única etnia nacional, constituindo assim, um só povo incorporado em uma nação unificada, num Estado uniétnico [...] Comparando o bloco unitário resultante da América portuguesa com o mosaico de quadros nacionais diversos que deu lugar a América hispânica, pode-se avaliar a extraordinária importância deste feito. Essa unidade resultou de um processo continuado e violento de unificação política, logrado mediante um esforço deliberado de supressão de toda identidade étnica discrepante e de repressão e opressão de toda tendência virtualmente separatista" (RIBEIRO, 2006, p.19-20)

A importância da longa transcrição de Darcy Ribeiro apresentada acima é que esta representa uma síntese sobre a identidade nacional e a coesão dos brasileiros. Ao exemplo da Espanha - que nestes dias em redigimos este trabalho encontra-se envolvida numa 
disputa quanto a chamada independência da Catalunha - poderíamos agregar o exemplo norte-americano ou o chinês.

A formação social norte-americana e a hispânica, conduzidas por povos - o inglês protestante e o católico de Madrid -, que mantinha a distância dos locais, diferenciou-se do já miscigenado português, no que resultou condições diferentes no que diz respeito a unidade e a coesão nacional.

Os Estados Unidos, por exemplo, encontra-se profundamente condicionado por seus problemas étnicos; assiste a crescente islamofobia, ao mesmo tempo em que o elementos hispânico torna-se cada vez mais numerosos. O problema da imigração islâmica também configura-se em problema chave na Europa ou na Rússia. Já a China, com suas 56 etnias, tem suas contradições exploradas por influência exógena, como é o caso dos muçulmanos de Xijiang ou os tibetanos.

Por certo o Brasil não está imune a manipulação de seu problema “étnico". Ao contrário, se apresentam historicamente, no debate sociológico - o qual desenvolveremos a seguir -, em ações ideológicas ${ }^{76}$, no geral fomentada por instituições estrangeiras ou ainda em certas políticas públicas - inspiradas em formações sociais pluriétnicas - que buscam reproduzir aqui modelos exógenos ${ }^{77}$.

O problema da identidade nacional deve ser visto sob a ótica do que singulariza o povo e a própria civilização brasileira. Segundo SPEKTOR (2014, P.27),

“[...] a identidade nacional do país centra-se no princípios de que o Brasil está posicionado sobre as bordas ou fronteiras da formação ocidental. O país estaria fora e dentro do Ocidente de vido a sua formação: é claramente ocidental quando comparado ao mundo islâmico, Índia ou China; não o é tão claramente se comparado às expressões globais do império anglo-saxão, como a África do Sul, na era do apartheid, o Canadá, a Austrália e a Nova Zelândia. No caso brasileiro, a 'miscigenação racial', o 'sincretismo religioso' e o legado ibérico dariam ao Brasil essa condição de 'extremo ocidente'. Estas

\footnotetext{
${ }^{76}$ Desde pelo menos os anos 1960, há uma forte presença de instituições estrangeiras, como a Ford Fundation, entre outras, no oferecimento de generosas bolsas de estudos nos programas de ciências sociais voltadas ao estudo do problema "étnico" ou "racial" brasileiro, os quais, não raro, tentam reproduzir conceitos da sociologia norte-americana numa formação social diversa como é a brasileira. Também a questão indígena, neste caso sobretudo através do aparato mundial da Igreja Católica, busca fomentar uma política indigenista atrasada, de segregação dos indígenas em verdadeiros zoológicos humanos - em áreas, em geral, ricas em recursos naturais, sobretudo na Amazônia.

${ }^{77}$ Refiro-me, por exemplo, ao modelo das cotas raciais, hoje praticamente universalizados nas Instituições universitárias. É inegável que no Brasil exista discriminação por cor de pele, sobretudo entre as classes sociais. Mas não se resolve a questão - de natureza sobretudo social - com medidas estranhas a nossa formação social.
} 
características não apenas seriam dados da formação do Brasil como também seriam fundamentalmente positivas: seriam, em sim mesmas, fonte de virtudes como a criatividade, a tolerância e a capacidade de empatia com outros povos".

Outro traço de nossa identidade ou singularidade no contexto das Nações, é a "premissa do excepcionalismo brasileiro". Afinal, continua, "o Brasil seria avis rara por chegar à independência como monarquia em uma região de repúblicas, falar português em vez de espanhol, expandir seu território quando todos os outros vizinhos se desmembram, obter soberania sem guerra revolucionária contra a metrópole, partilhar a fronteira com dez vizinhos contíguos sem ir à guerra contra nenhum deles ao longo de um século e meio, e ser a única potência emergente representada nos BRICS que optou por não construir um artefato nuclear" (ibidem, p.27-28).

\section{Raízes do pensamento estratégico: a visão de José Bonifácio.}

No estudo das raízes da identidade nacional, devemos retornar, se quisermos compreender a gênese do pensamento nacional, o pensamento de José Bonifácio de Andrada e Silva.

A "revolução brasílica"78 proposta por José Bonifácio de Andrada e Silva nas origens do Brasil-nação - nosso primeiro projeto de estruturação nacional ou projeto nacional - deve ser resgatado, quase duzentos anos após sua formulação, sobretudo porque em alguns aspectos chaves - como a integração completa do território ou a coesão dos brasileiros em torno de um projeto nacional - ainda são tarefas por realizar, estando o Brasil há poucos anos para o bicentenário de sua Independência nacional.

Por ocasião dos 250 anos da nascimento do Patriarca, publicamos ensaio ${ }^{79}$ que buscou resgatar aspectos nodais do projeto político reformista de José Bonifácio, buscando estabelecer diálogo com desafios contemporâneos dos brasileiros.

No texto, discutimos os fundamentos do projeto andradino a partir de quatro questões fundamentais: a defesa da unidade do território; a compreensão sobre a necessidade de

\footnotetext{
${ }^{78}$ Termo cunhado por José Bonifácio, quem defendeu que "sendo esta a vontade dos Povos já de sobejo pronunciada nas Províncias, e sobretudo nesta Capital, cujo entusiasmo até tem sido necessário moderar, é impossível que S.A.R. deixe de anuir quanto antes ao único meio de centralizar sempre em Si a Revolução Brasílica e dirigi-la a bem dos Povos" (Carta a Caldeira Brant, 4 de outubro de 1822).

79 Ver Carmona, R. Bonifácio, gênese do pensamento nacional in Revista Tensões Mundiais. Fortaleza: Editora UECE, 2014.
} 
coesão dos brasileiros; a forma dual - negociação e conflito - pela qual se efetivou a Independência; e a definição de bases para a autonomia nacional, seja pela defesa da industrialização, seja, notadamente, pela definição de grandes princípios orientadores da política externa brasileira. Para efeitos desta sessão, nos concentraremos na discussão dos dois primeiros aspectos.

Trata-se de duas questões basilares do projeto nacional: (1) a preservação da unidade nacional, em especial no que diz respeito a coesão territorial do vasto território nacional, então isolado em "ilhas" precariamente comunicadas e (2) a busca de uma identidade nacional dos brasileiros que permitisse maior coesão nacional a partir de maior homogeneidade cultural e racial.

\section{A unidade e a indivisibilidade do território nacional.}

José Bonifácio comungava, em princípio, da ideia de constituição de um vasto Império luso-brasileiro com sede no Brasil. De fato, observando a questão a partir de uma visão geopolítica contemporânea, se trataria potencialmente de uma grandiosa nação distribuída por toda a esfera terrestre, dado o fato das colônias portuguesas espalharem-se pela África e Ásia.

O grandioso Império não era ideia que aparecera então: "vêm desde Antônio Vieira no século XVII, e do diplomata D. Luís da Cunha, no XVIII. Essas ideias foram retomadas por D. Rodrigo de Sousa Coutinho no início do século XIX, diante da possibilidade de invasão de Portugal pelos exércitos de Napoleão. Dizia Coutinho, sobre Portugal que 'ainda resta ao seu soberano, e a seus povos, o irem criar um poderoso Império no Brasil, donde se volte a reconquistar o que se possa ter perdido na Europa"” (1996b, p. 165). Hoje, sobretudo tendo em vista grandes tendências deste século XXI, não poderíamos deixar de apontar o visionário que foi a declaração do primeiro-ministro de D. João VI, sobretudo observando hoje o momento de relativa decadência geopolítica da Europa.

Segundo Maxwell (1993 apud Wefford, 1996b, p. 156), na proposta de D. Luis da Cunha, por exemplo, o rei passaria a ter o titulo de "Imperador do Oeste" e nomearia um vice-rei para governar Lisboa.

À época, a solução intermediária, diante da consumação da invasão francesa de Portugal, foi a transferência da Corte para o Rio, em 1808. 
O fato é que desde 1808, com o deslocamento de D. João VI para o Brasil, o país avançara em múltiplos aspectos na sua autonomia, seja administrativa, seja no plano econômico (por exemplo, pela abertura dos portos) ou mesmo cultural (crescimento de aspirações nativistas). Desde 1815, inclusive, o Brasil já passara a categoria de Reino Unido a Portugal e Algarves. Assim, "não se desliga de Portugal, mas a ele se nivela" (2004, p. 26)

A partir da revolução do Porto de 1820, entretanto, ocorre a exigência do retorno imediato de D. João VI a Lisboa - que se efetivaria no ano seguinte -, recrudescendo pressões recolonialistas de Portugal sobre o Brasil (1998b, p. 66-67)

A autonomia brasileira, como aponta Costa (1998b, p. 67),

[...]"evidentemente divergia dos objetivos dos revolucionários portugueses, desejosos de anular as medidas liberais que, permitindo ao estrangeiro o acesso direto às mercadorias brasileiras, prejudicam os comerciantes e produtores portugueses [...] a política nitidamente recolonizadora promovida pelas Cortes, representante do interesse dos comerciantes e produtores portugueses prejudicados pela abertura dos portos e pela extinção dos monopólios e privilégios provocou crescente tensão entre brasileiros e portugueses".

A escalada das diferenças entre portugueses e brasileiros põe em xeque assim a ideia do Império luso-brasileiro com sede no Brasil.

$\mathrm{Na}$ verdade, a autonomia do Brasil vinha de longe, num crescente irreversível. Como afirma Maxwell (1993 apud Wefford, 2006b, p. 156), importante brasilianista, já no século XVIII, a relação entre Brasil e Portugal "nunca foi meramente de servo colonial e senhor europeu". Afinal, as "atitudes diferenciadas por parte dos brasileiros remontam ao século XVII, quando, numa atitude inusitada para meros colonos, os povoadores de São Paulo, Bahia e Maranhão decidiram reconhecer D. João IV” em vez da coroa espanhola, na época da denominada União Ibérica. São deste período também as gloriosas Batalhas dos Guararapes, marco do surgimento do Exército brasileiro, quando o povo em armas, em suas três vertentes originadoras da nacionalidade, derrotou militarmente - num exemplo clássico de vitória lograda num confronto assimétrico - a grande potência da época, o Império batavo.

No governo modernizador do Marquês de Pombal, este "escolheu brasileiros para funções de governo" - alguns deles inclusive tomariam parte nos movimentos independentistas na colônia. Era brasileiro, por exemplo, o reitor da Universidade de Coimbra nomeado 
por Pombal que efetivou grandiosa reforma modernizadora naquela instituição, livrandoa do nefasto dogmatismo jesuíta anticientífico (2006b, p. 157)

A despeito da inexistência de instituições universitárias na colônia antes da chegada de D. João VI, entre 1772, data da reforma pombalina e o último ano do século, mais de quinhentos brasileiros se graduaram em Coimbra - formando assim, importante elite intelectual nativista (2006b, p. 158).

A demonstração que José Bonifácio já assume o ministério do Reino planejando a Independência, pode ser exemplificada com uma de suas primeiras atitudes, ainda em fevereiro de 1822, de convocar um Conselho de Procuradores das Províncias, embrião de uma Constituinte - esta, seria convocada meses depois, em 3 de junho de 1822, antes da própria proclamação formal de Independência.

A reação das Cortes portuguesas aceleraria a decisão dos patriotas brasileiros.

"Nos últimos dias de agosto chegaram notícias das recentes decisões das Cortes reduzindo o príncipe a um mero 'delegado temporário do Soberano Congresso', de ação circunscrita às províncias onde exercia autoridade, 'com secretários de Estado nomeados em Lisboa, que passava a ser a verdadeira sede do governo do Brasil'. Ficava anulada a convocação do Conselho de Procuradores e as Cortes mandavam processar 'quantos houvessem procedido contra sua política visando especialmente José Bonifácio 'tido como responsável pelo que se passava"” (1998b, p. 76).

Assim, o confronto define a opção pela Independência efetiva do Brasil. Apresenta-se então a questão de qual o melhor sistema político a adotar para transitar da Colônia para a Independência: se uma república, como era a tendência nas colônias que iam se tornando independentes nas Américas ou com a manutenção do regime monárquico.

Como lembra Dolhmikoff (1996:, p.136),

“As primeiras décadas do século XIX foram marcadas pela busca, não só no Brasil como também na Europa, de um regime que se colocasse a meio caminho entre despotismo e democracia. [(...]) A monarquia constitucional, adotada na França em 1814, tornou-se o principal modelo daqueles que desejavam evitar tanto os excessos despóticos à Ancien Régime como os perigos das revoluções ou da "anarquia democrática". Consoante com essa tendência, Bonifácio foi ardoroso defensor da monarquia constitucional".

Nas palavras de Bonifácio, em fins de 1823, sua defesa da Monarquia - constitucional, reitere-se -, derivava de sua visão de que se tratava do "único sistema que poderia ainda conservar unida e solida esta peça majestosa e inteiriça de arquitetura social, desde o Prata ao Amazonas". Para ele, "sem a Monarquia não haveria um centro de força e união, e sem 
esta, não se poderia resistir às Cortes de Portugal e adquirir a Independência Nacional" (2004, p. 250-251).

Operou-se assim uma transição na superestrutura política que não geraria ruptura com o Estado aqui implementado - especialmente desde 1808 -, mas sua autonomização na forma de um novo Estado nacional a partir de 7 de setembro de 1822. Para isso, até mesmo um ramo da dinastia Bragança foi cooptado para a realização deste movimento de transição - por certo, para D. Pedro I, entre ser mais um herdeiro em Lisboa ou liderar o novo país, não terá sido difícil fazer a escolha.

Para Bonifácio, o modelo republicano ameaçaria a frágil coesão nacional, sobretudo no que diz respeito ao território. Observando a experiência da América espanhola, não será difícil dar razão ao Patriarca, observando o êxito da monarquia brasileira como instrumento de preservação da unidade do território nacional - mesmo que a custa de forte repressão sobre legitimas revoltas populares, sobretudo no período da regência trina (1831-1840 $)^{80}$ - e assim, de transição para a efetiva Independência nacional.

Pode-se derivar da lógica de José Bonifácio, a ideia de que, sob um regime republicano, a Independência poderia levar a tendências territoriais centrifugas. Afinal, de fato, era o Brasil "dividido em províncias distantes, isoladas, com costumes e pretensões diversas, uma população heterogênea e dispersa" (1998b, p. 87).

\section{A coesão dos brasileiros}

Questão basilar, pressuposto para a definitiva Independência, era, para o Patriarca, o problema de avançar na coesão dos brasileiros, na constituição de uma identidade que permitisse a união nacional em torno de interesses civilizatórios comuns.

Não por acaso, a heterogeneidade do povo brasileiro em suas origens, foi grande fonte de preocupação de José Bonifácio quando da Independência nacional: cindido em agrupamentos étnicos conflitados, estava o Brasil irremediavelmente ameaçado de ter o mesmo destino da América espanhola, isto é, a fragmentação territorial e populacional.

80 Dentre as quais, a Balaiada (1838 - 1841), a Cabanagem (1835 - 1840), a Sabinada (1837 - 1838), 0 Levante dos Malês (1835), a Cabanada (1832 - 1835) e a Revolução Farroupilha ou Guerra dos Farrapos $(1835-1845)$. 
O Patriarca propunha a união dos brasileiros: se opunha decisivamente a ideia de que parte dos brasileiros eram inimigo interno. Era como ele compreendia a escravidão: fator de divisão dos brasileiros.

Para além da própria questão humana, como afirma Dolhnikoff, "a escravidão representava permanente perigo para a manutenção da ordem interna, apontando para a possibilidade de repetição, no Brasil, dos levantes de escravos ocorridos no Haiti no final do século XVIII" (1996, p. 131).

José Bonifácio via que "a escravidão era uma ameaça a segurança nacional, pois enfraquecia o poder nacional" (2006, p.19). Visto hodiernamente, o problema de minorias nacionais é fator de vulnerabilidade geopolítica de países como Estados Unidos, China, Índia ou Rússia. Mesmo no caso brasileiro, a constante manipulação do fator indígena por interesses que estão longe de serem humanitários, também é fator de preocupação estratégica.

Na transição para a Independência - e logo após, como membro da Constituinte - o Patriarca retoma com força duas das proposições dos Apontamentos que calavam fundo no âmago da sociedade brasileira do início do século XIX, e que, aceitas fossem, teriam precipitado avanços que o Brasil só observaria juridicamente no final do século. $\mathrm{Na}$ prática, questão pendente, em certa medida, até os nossos dias: a incorporação dos índios à nação brasileira - projeto que, anos mais tarde, seria assumido pelo Marechal Rondon, celebre brasileiro - e a causa da valorização do elemento negro como uma das fortalezas de nossa formação social e assim, de nossa identidade nacional.

O primeiro projeto, denominado de "Apontamentos para a Civilização dos Índios bravos do Império do Brasil", propunha um conjunto de medidas para a integração dos índios, com seu aldeamento, criação de escolas, etc. O segundo grande projeto - ainda mais radical no contexto de uma sociedade profundamente escravocrata - foi a "Representação à Assembleia Constituinte sobre a escravatura", na qual o Patriarca propunha o fim da escravidão, ainda que, consciente das resistências, o redigiu propondo realizá-la de forma gradual, e assim irreversível. Some-se a isso, a alternativa econômica para a emancipação de índios e negros, para os quais, Bonifácio propunha um programa de distribuição de terras ociosas ou mal aproveitadas.

Para conformar a identidade nacional, Bonifácio foi buscar analogia na mineralogia, sua especialidade, propondo "amalgamar tantos metais diversos, para que saia um todo 
homogêneo e compacto, que não se esfarele ao pequeno toque de qualquer nova convulsão política”. Nesse esforço nacional, propunha até mesmo beneficio pecuniário para incentivar casamentos mistos entre brancos, índios e negros.

Ao defender a miscigenação, José Bonifácio foi quase um futurólogo, como denominou Gilberto Freyre (1972, p. 16). Segundo o mestre dos Apipucos, "isto numa época em que raros pensadores políticos, na Europa e no próprio Brasil, seriam capazes de conceber como socialmente valido um futuro nacional extra-europeu que viesse a valorizar de tal modo o elemento não europeu de etnia e de cultura".

Bonifácio defendeu ideia que se imporia na prática - a miscigenação e o amalgamento -, mas que, fruto da hegemonia de uma sociologia racista, adepta da "pureza" étnica - hoje, sabiamente, uma aberração -, tardaria por ser valorizada pelos brasileiros.

Só o próprio Gilberto Freyre, com seu magistral Casa Grande e Senzala - que, aliás, neste ano de 2013 cumpre 80 anos de sua publicação -, enfrentaria, com argumentos sólidos e irrefutáveis, apoiando-se na trajetória da formação social brasileira, a visão negativista sobre nosso povo, por largos anos hegemônica.

O Patriarca, visionário, defendeu pela primeira vez a ideia de miscigenação numa carta ao Conde de Funchal em 1812. Como observa Weffort (2006b, p. 175), Bonifácio em muito se antecipou às virtudes da miscigenação, "que, real no Brasil desde o século XVI, só será admitida de modo consistente pelas elites intelectuais no século XX”.

Admissão parcial, diga-se, ainda neste século XXI, aja visto manifestações racialistas que ainda observamos no Brasil atual, sobretudo num setor adepto de teses pós-modernas e multiculturalistas - uma pregação estimulada por agências estrangeiras, cientes do dano aos propósitos de união nacional dos brasileiros, como já ressaltara José Bonifácio. Outra face contemporânea deste tema é a política de segregação indígena todavia praticada.

A formação do povo-novo, da etnia brasileira - nas felizes expressões de Darcy Ribeiro -, podem converter-se, neste século XXI, numa vantagem civilizatória dos brasileiros, no sentido de sua unidade no difícil curso, com muitos obstáculos, para sua realização nacional. Uma singularidade brasileira, por exemplo, em relação a outros grandes polos no sistema internacional contemporâneo, sejam os emergentes, como os demais BRICS, sejam os tradicionais, como os Estados Unidos e o bloco europeu, todos de conformação 
multiétnica, envoltos em conflitos ou pelos menos marcadas diferenças entre agrupamentos étnicos dentro de seu território.

O Patriarca também anteciparia uma tendência brasileira, a de incorporação e assimilação do diferente. Dizia o libertador que "nós não conhecemos diferenças nem distinções na família humana. Como brasileiros serão tratados por nós o chinês e o luso, o egípcio e o haitiano, o adorador do sol e de Maomé". (1996, p. 126).

José Bonifácio também se referia a singularidade e originalidade da formação social brasileira, que aliada as potencialidade do território, poderiam derivar na grande potencia brasílica.

"O brasileiro que possui uma terra virgem debaixo de um céu amigo recebeu das mãos da benigna Natureza todo o físico da felicidade, e só deve procurar formá-lo em bases morais de uma boa Constituição que perpetue nossos bons costumes. Devemos ser os chineses do novo mundo, sem escravidão política e sem mornos. Amemos pois nossos usos e costumes, ainda que a Europa ria de nós”. (2006b, p. 176)

A referência aqui a China - ou Brasil como nova China - provavelmente deriva do papel fascinante que a China ainda ocupava no início do século XIX, do poderoso Império do meio, autárquico, apoiado em suas próprias forças - e que logo depois seria submetido à força pelo imperialismo, iniciando 150 anos de humilhação nacional - como dizem hoje os dirigentes chineses - só encerrado com a revolução chinesa de 1949, epopeia libertadora daquele povo.

$* * *$

Após apresentar o que chamamos de gênese de nosso pensamento social, cabe realizar uma digressão pelo pensamento filosófico clássico de Fichte, que nos dará base para a compreensão do papel do problema nacional na coesão para o enfrentamento dos desafios de uma nação.

Fichte é pedra angular deste grande sistema filosófico que é o idealismo alemão. Sua obra mais importante é Fundamentos de toda a doutrina da ciência, 1794. Teve interação em vida com Kant; serviu de introdução a Hegel. Sua explicação do $e u$, a partir de explicação dialética - tese, antítese e síntese - se converteu em clássico da filosofia universal. 
Outra obra importante de Fichte é Fundamentação do direito natural segundo os princípios da doutrina da ciência, 1796, onde expõe o conceito de "Urrecht", correspondente às tarefas de Estado, na qual apresenta a ideia de um Estado autárquico com peculiaridades próximas ao socialismo. Em Estado comercialmente fechado, de 1800, expõe ideias que fazer críticos considerarem Fichte o primeiro alemão que esboçou traços básicos de um Estado socialista.

Mas será seus Reden an die Deutsche Nation (Discursos a Nação Alemã) que nos interessa resgatar aqui para efeitos deste capitulo e desta sessão. Depois do acordo de paz em Tilsit, em 1807, com tropas francesas estacionadas em Berlim, Fichte pronuncia, entre os invernos de 1807 e 1808, seus famosos Discursos, “que são recebidos com grande entusiasmo. Com eles, tenta elevar o espirito do povo alemão, animando-o a se levantar contra a ocupação napoleônica" (FICHTE, 2002, p. XX).

Quais conteúdos predominam nos discursos? Em primeiro lugar, é obra fundamentalmente pedagógica, ao qual se dedicam o segundo, terceiro, nono, decimo e decimo primeiro discurso, de maneira quase exclusiva. Os discursos terceiro, quarto, sexto e sétimo, se dedicam a elaborar reflexões sobre a natureza do que é especificamente alemão e sobre a diferença do caráter alemão em relação a outros povos. O quinto trata de analisar consequências que trazem aos alemães as diferenças estabelecidas, o oitavo, fala sobre a noção de patriotismo.

$\mathrm{Na}$ introdução ao pensamento de Fichte, que utilizamos na presente resenha, Varela e Acosta dizem que,

"A causa imediata e ao mesmo tempo o ponto de partida desta obra, é a situação em que
se encontra, neste momento, a "Nação" alemã; uma Nação que parece haver deixado de
sê-la ou pelo menos está em transção para deixar de ser, se é que já foi alguma vez. A
Prússia, foi, por um lado, ocupada por Napoleão; A Confederação do Reno, por outro,
estabeleceu uma aliança com os franceses (...) não só a Nação alemã se encontra em
perigo, mas também o Estado está também sob risco de desintegrar-se". Sintetizando,
trata-se de uma obra "cuja orientação está marcada decididamente por um objetivo
político consistente de transformar o estado da Nação alemã" (tradução livre, idem ibid,
p.22) Já no primeiro discurso, oferece uma interpretação histórica da época: "uma época dominada pelo egoísmo, o interesse pessoal e a renúncia do cidadão a pensar em comunidade e o desinteresse, em consequência, pelo Estado como forma de organização da mesma", em que "coincide com a desintegração e, em consequência, risco de desaparecimento da Alemanha”. 
Pra ele, "a Alemanha existiu como nação, dispõe de uma herança e tradição, cujas peculiaridades são a "originalidade" e a "primigeneidade" e que estas particularidades constituem o ponto de referência para organizar uma nova educação para os alemães, e por tanto, para a salvação da Nação”.

Para Fichte, o alemão é uma qualidade unitária e autônoma, é uma nação que tem história, tem uma cultura e um passado político. Em cinco discursos busca demonstrar estas afirmações. Um dos fundamentos disto é a existência da língua alemã. Com ela, desenvolveu-se, "servindo-se do veículo que esta constitui, uma cultura", uma filosofia e uma religião.

Assim, a Alemanha possui "não só particularidades especificas que a constituem como nação, mas também dos pressupostos necessários no qual possa se apoiar e configurar educação estendida como modo de determinar a vontade do cidadão, e por meio dela, chegar, definitivamente, a transformação do Estado".

- Para Fichte, a educação "como nacional que tem que ser, deve cobrir a todos os grupos sem distinção, sendo uma educação popular no autêntico sentido da palavra (...) com objetivos de "auto superação, submissão dos instintos egoístas a ideia do todo (...) entendido, sem dúvida, esse todo, não como organizado socialmente na forma de Estado, mas como uma realidade superior na forma de Nação".

- "Seu objetivo final e último consiste em recuperar a unidade da nação alemã, pois a existência de divisões se oferece como um contra sentido, carregado de perigos". Fichte está pensando "nos inconveniente e nas repercussões políticas que uma organização estamental da sociedade causou a nação alemã, o que de uma maneira especial se manifestou sobre a multiplicidade de organizações políticas territoriais autônomas”.

Assim, explica o sentido final dos Discursos e sua natureza: a consecução de um Estado autônomo, e definitivamente, a conformação de uma Nação.

Em síntese, o pensamento de Fichte serviu a uma nação humilhada e ocupada pelo elemento estrangeiro recobrar sua grandeza.

$* * *$ 
Cabe-nos agora, para concluir a presente sessão, repassar questões chaves do pensamento social brasileiro que nos permitirão, em seu conjunto, apresentar a relevância do pensamento social para a constituição da Grande estratégia nacional.

Comecemos com o grande ponto de ruptura do pensamento social brasileiro. Refiro-me, antes que nada, ao aparecimento de Casa Grande e Senzala (1933), de Gilberto Freyre; Raízes do Brasil (1936), de Sergio Buarque de Holanda; e Formação do Brasil Contemporâneo (1942), de Caio Prado Júnior são consideradas marco fundamental no debate sobre a formação social brasileira, pois a partir de então, inauguram-se e se afirmam novos paradigmas no debate. Temporalmente as três obras aparecem no momento seguinte à Revolução de 1930, marco fundador de um longo período de modernização e desenvolvimento do capitalismo no Brasil.

Um primeiro grande mérito das três obras - e ponto de convergência entre elas, ressalvada diferenças de enfoques e gradações - é precisamente a ruptura com o pensamento hegemônico vigente até então a respeito da Formação Social Brasileira. Exemplo maior dessa "viragem" na interpretação de nossa formação social é forma como nos vemos a nós mesmos: a miscigenação, de grande macula de nosso povo, de "mancha" que impede um futuro melhor de nossa civilização, passa a ser uma sublime especificidade - visão presente marcadamente em Casa Grande e Senzala, mas também, mais comedidamente, nas outras duas obras em questão. Mas não obstante essa ruptura, representada, em especial, por Casa Grande e Senzala, é preciso reconhecer a profícua produção de obras de interpretação do Brasil em todo um período anterior, que, segundo nossa hipótese, foram determinante no acumulo de conhecimento sociológico que permitiria esse salto no pensamento social na década de $1930^{81}$.

\footnotetext{
${ }^{81}$ Esquematicamente, podemos dizer, com o risco que se incorre em generalizações do tipo e ressalvadas possíveis omissões, que dentre as obras chaves do pensamento social no período compreendido entre 0 final do século XIX e 1933, estão as que compartem da visão hegemônica da época, como O Abolicionismo (1883) e Minha Formação (1900), ambos de Joaquim Nabuco; História da Literatura Brasileira (1888), de Sílvio Romero; Os Sertões (1902), de Euclides da Cunha; Populações Meridionais do Brasil (1920), de Oliveira Vianna, Retrato do Brasil (1928), de Paulo Prado e Macunaíma (1928), de Mário de Andrade. Há também obras, digamos, "contra-hegemônicas" - em relação à hegemonia da época -, como A América Latina: males de origem (1905), de Manuel Bonfim, fruto de fortes contestações de Sílvio Romero. Nessa lista de contribuições relevantes ao pensamento social brasileiro, segundo pontos de vistas diversos, podemos incluir A Ilusão Americana (1893), de Eduardo Prado; Porque me ufano de meu país (1900), de Afonso Celso, O Problema Nacional Brasileiro (1911) e A organização nacional (1914), de Alberto Torres (1865-1917) e Agrarismo e Industrialismo - ensaio marxista-leninista sobre a revolta de São Paulo e a guerra de classes no Brasil (1926), de Octavio Brandão, tida como a primeira obra que analisa o Brasil a luz do marxismo.
} 
Observamos o argumento em Raça, clima e evolução no século XIX - do pessimismo à descoberta do povo brasileiro, de Jair de Sousa Ramos e Marcos Chor Maio. Segundo estes autores, "podemos comparar as interpretações sobre a sociedade brasileira a um quadro que já foi pintado de muitas maneiras. E um dos mais duradouros destes "retratos do Brasil" é aquele de um país de homens e mulheres hereditariamente preguiçosos e que, além disso, sofrem diante de uma natureza exuberante que lhes aniquila" (in LESSA, 2005, p.75).

Produzidas por cientistas e intelectuais estrangeiros, na maioria europeus, principalmente no século XIX, "ainda que possa parecer paradoxal, essas imagens pessimistas foram aceitas também por intelectuais e cientistas brasileiros”. Há uma longa tradição no pensamento ocidental de teorias que postulam a existência de um determinismo climático ou geográfico sobre os comportamentos humanos. No século XVIII, pesquisas medicas, por exemplo, emprestam cientificidade ao determinismo climático. $\mathrm{O}$ filosofo Montesquieu esboça uma explicação psicológica sobre os efeitos do clima sobre as raças.

O pensamento europeu do século XIX também atribuiu grande importância ao determinismo racial. As teorias racialistas diferem das racistas. A primeira, refere-se doutrinas sobre as diferenças humanas, enquanto as segunda, trata de ódio ou desprezo pelo diferente.

Três dos grande interpretes do Brasil no século XIX e início do século XX tem suas obras “contaminadas" por estes determinismos: Silvio Romero, Raimundo Nina Rodrigues e Euclides da Cunha.

Outro texto que merece ser aqui apresentado é Resposta à maldição - Brasil tropical e viável, da geografa Iná Elias de Castro. Para ela, "Gigante pela própria natureza",

“O Brasil é um país singular. Colonizado a partir do século XVI, é a nação tropical de maior extensão. Os traços mais marcantes e distintivos de sua natureza foram, desde o início, objeto de admiração, comentários e descrições, favoráveis umas, desfavoráveis outras. Hoje, a extensão do território e a natureza generosa, que possibilita a produção de uma gama variada de produtos agrícolas, a existência de recursos minerais, a disponibilidade de uma grande biodiversidade, a ausência de barreiras naturais à circulação e à ocupação humana, como montanhas elevadas, desertos, pântanos ou ainda a ausência de catástrofes naturais como vulcões, 
furacões ou maremotos, compõe na atualidade um quadro percebido como privilegiado".

Assim, nunca passou desapercebido por quem buscou explica-lo, "o contraste entre uma natureza prodiga e uma sociedade amesquinhada pela pobreza e a ignorância da maioria de seus membros" (in LESSA, 2005. P.91).

Numa sessão seguinte de seu artigo, a professora Castro discute a questão geográfica propriamente subjacente a discussão sobre a formação social. Para ela,

"Foi no contexto político territorial do século XIX europeu que a geografia tornou-se disciplina acadêmica e incorporou questões relativas ao Estado: localização, posição, território, recursos, fronteiras, população, relação com outros Estados, etc.”. Deu-se em "um momento de grandes disputas territoriais no continente e fora dele e de consolidação não apenas da ideia de nação, mas da sua territorialidade política como condição essencial da sua existência". "No século XIX a consolidação da forma Estado como um projeto territorial e socialmente enraizado teve no nacionalismo um recurso ideológico necessário. Na construção desse imaginário nacionalista (...) a apropriação do conhecimento produzido pela geografia foi e tem sido estratégico (...) para produzir um imaginário territorial como componente inseparável do destino da nação".

- "Paralelamente à tarefa de melhor dar a conhecer o território como base do enraizamento da nação, era fundamental nesse processo desconstruir as ressonâncias das imagens negativas, muitas em alguns dos meios intelectuais brasileiros, sobre o clima e a natureza dos trópicos, e reafirmar, a partir dessa mesma natureza, todas as possibilidades reservadas ao projeto civilizatório da nação em formação. Essa desconstrução tinha o sentido tanto de destacar e valorizar as potencialidades do território e do povo, fundamentos do ethos nacionalista em muitas sociedades, como, pragmaticamente, elaborar uma imagem de país mais adequada à ambição das classes produtoras de projetar-se no exterior..."

Sobre a "construção de representações sobre o país e do imaginário nacional. A extensão, a potencialidade, as qualidades do povo e da natureza para o progresso são eixos essenciais na elaboração de um conhecimento do país que se empenhara em imaginário de um paraíso tropical fadado à preguiça e à inépcia (...) O conhecimento do território do país desconstruía pouco a pouco as imagens negativas da impenetrabilidade das escarpas litorâneas, das limitações do clima quente e úmido para a salubridade dos seus habitantes, da força da floresta que os apequenavam. O relevo, ao contrário da primeira impressão dos viajantes, mais facilita do que dificulta a exploração e o avanço da ocupação do país. O clima é outro item central. O calor, tão assustador aos olhos do europeu, é ponderado com os ventos e as variações de temperatura. $\mathrm{O}$ sol inclemente é apontado como "ótimo desinfetante".

Assim, conclui, "o clima tropical, mais do que um fator de atraso, era demonstrado como uma vantagem que a nação estava pouco a pouco dando provas de ser capaz de aproveitar" (idem ibid, p.94-95).

Em seguida, apresentaremos texto denominado Uma certa ideia de Brasil, de Cesar Benjamin. Para o autor, podemos identificar um enigma brasileiro, que caracterizaria nossas muitas singularidades: sociedade recente, produto da expansão europeia, 
concebida desde o início para servir ao mercado mundial, alicerçadas em escravismo prolongado e tardio, única monarquia em continente republicano, assentada sobre extensa base territorial situada nos trópicos, com um povo em processo de formação, sem um passado profundo onde pudesse ancorar sua identidade.

Como visto acima, em outros autores, durante muito tempo, copiamos saberes da Europa: o determinismo geográfico (“a civilização é uma conquista dos países frios, pois é a vitorias das sociedades contra as dificuldades impostas pelo ambiente") e racial ("a civilização expressa o potencial de alguns subgrupos humanos mais aptos"). Ambos, diz Benjamin, irremediavelmente nos condenavam. Assim, "enquanto o Brasil se olhou no espelho europeu, só pode construir uma imagem negativa e pessimista de si mesmo, ao constatar sua obvia condição não-europeia".

Somente cem anos após a Independência, diz Benjamin, "o conservador" Gilberto Freyre fez "uma revolucionária leitura de Brasil": "Abandonando o enfoque de raça, enfatizando o da cultura, Freyre revirou tudo de ponta cabeça, com um tremendo resgate do papel civilizatório de negros e índios". Do português, “elogiou a miscibilidade, a plasticidade e a mobilidade, características que os distinguiam dos colonizadores de origem anglosaxão".

Para o autor, a colonização da Brasil não foi obra do Estado ou de outras instituições formais, muito fracas, mas da família patriarcal, "em torno da qual constituiu-se um modo de vida completo e especifico". A família extensa, cheia de agregados, a poligamia, a escassez de mulher branca, favoreciam amplo intercambio; muitos "mulatos, cafuzos e mamelucos" iam matizado a dualidade que em princípio apartava senhores e escravos.

Assim, a singularidade brasileira encontrava-se na cultura, "obra coletiva de gerações anônimas". "Uma cultura de síntese, que afrouxou e diluiu a tensão entre os códigos morais e o mundo-da-vida, tensão constitutiva das sociedades de tradição judaico-cristã". Índios e negros nunca foram completamente moralizados pelo colonizador.

Quanto a Sergio Buarque de Holanda, autor de Raízes do Brasil, uma "clássico de nascença" - nas palavras de Antônio Candido, em seu clássico prefacio à obra -, esta buscou compreender como ocorrera a transição de uma sociedade rural, ibérica, para a modernidade urbana e "americana". Paulista, Sergio Buarque de Holanda não sentia nostalgia pelo Brasil agrário que se desfazia, nem acreditava em soluções autoritárias, tão em voga, da modernização pelo alto. 
$\mathrm{Na}$ visão de Buarque de Holanda, somos uma sociedade transplantada, mas com características próprias. “A dimensão privada e afetiva da vida sempre se sobrepôs - para o bem e para o mal - à impessoalidade burocrática, não raro descambando para o passionalismo e a impulsividade típica do homem cordial, num quadro de ausência de direitos formais”. Essa é a explicação do homem cordial de Buarque de Holanda, que até hoje inspira debates sociológicos.

Na visão do autor paulista, o êxito da colonização portuguesa, não decorreu de "um empreendimento metódico e racional", mas "buscou a riqueza que custa ousadia, não a riqueza que custa trabalho. A ética da aventura prevaleceu sobre a ética do trabalho". Herança atrasada, foi a base da nacionalidade, as "raízes do Brasil”. Deve-se buscar um caminho para superar o atraso.

Buarque de Holanda anuncia que "nossa revolução" está em marcha, com a dissolução do complexo ibérico de base rural e o surgimento de ator decisivo, as massas urbanas, libertada da tutela de senhores locais, não mais demandante de favores, mas de direitos. Transformaríamos o homem cordial em cidadão.

Um terceiro livro clássico de interpretação do Brasil é de Caio Prado Junior, Formação do Brasil Contemporâneo. Segundo Benjamin, é “a primeira grande síntese historiográfica brasileira em quase cem anos, se contarmos desde Varnhagen”. Realiza o desvendamento de nossa origem como empresa colonial, a qual se transformaria numa nação.

A colonização do Brasil representou um problema novo, pois os métodos tradicionais de colonização "- a pilhagem de riquezas acumuladas, a cobrança de tributos e o estabelecimento de comercio desigual - não se aplicava a estas terras sem metal preciosos (no século XVI) e habitadas por grupos humanos dispersos, que viviam no neolítico".

A solução do problema demandou trinta anos:

"Organizou-se finalmente uma empresa territorial de grande dimensão, com administração portuguesa, capitais holandeses e venezianos, mão-de-obra indígena e africana, tecnologia desenvolvida em Chipre e matéria-prima dos Açores e da Ilha da Madeira - a cana". "Nos séculos XVI e XVII foi excelente o negócio do açúcar, a primeira mercadoria de consumo de massas em escala planetária, em torno do qual se formou o moderno mercado mundial". Depois, veio o magnifico negócio do ouro, pelo qual a Inglaterra, sem jamais ter tido uma mina de ouro, acumulou enormes reservas "que lhe permitiram criar, no século XIX, o primeiro padrão monetário mundial (o padrão libraouro), símbolo e suporte de sua hegemonia". A partir de 1840 até a entrada do século XX, foi maravilhoso o negócio do café, "estimulante de baixo custo e fácil distribuição, 
ofertado à classe trabalhadora da Europa e dos EUA que precisava ser disciplinada para o trabalho fabril". "Além disso, permeando toda a nossa história, foi sempre estupendo o negócio do endividamento perpetuo dessa empresa Brasil, induzido pelos seus controladores de fora".

A "empresa" foi sendo povoada e criando um povo, que foi tomando consciência. "Esse processo histórico se dilatou e se arrasta. Mas ainda não chegou a seu termo", nas palavras de Prado Junior, citadas em Benjamin. Assim, estas palavras "refletem o choque entre o Brasil empresa-para-os-outros, que ainda somos, e o Brasil nação-para-si, que desejamos ser". "Fazê-la chegar a seu termo", realizando a revolução brasileira "é fazer desabrochar a última grande nacionalidade do Ocidente moderno, uma nacionalidade tardia, cujos potenciais permanecem em grande medida incubados".

Por fim, obra fundamental para conhecer as raízes de nossa formação social é Formação Econômica do Brasil, de Celso Furtado. Descartando a presença do feudalismo em nossa formação social, a obra se apoia na análise dos ciclos econômicos.

Para ele, "o fortalecimento do mercado interno, o desenvolvimento da indústria e a formação de um núcleo endógeno de criação e difusão de progresso técnico - condições para a superação do subdesenvolvimento - não poderiam resultar de forças espontâneas".

“Tornou-se clássica sua análise sobre a adoção pelo Brasil, de maneira inovadora e pragmática, de eficazes política anticíclicas em plena crise de 1929-1933, antes mesmo que essas políticas tivessem sido claramente modeladas pela moderna teoria econômica. Elas criaram uma situação nova, que criou as bases do processo de industrialização".

Em seu conjunto, argumenta Cesar Benjamin, "tributarias de diferentes influencias notadamente Franz Boas, Max Weber, Karl Marx e John M. Keynes, nessa ordem -, essas quatro obras seminais lançaram as bases da moderna ciência social brasileira e permitiram o início de uma fecunda reinterpretação do Brasil". Como pano de fundo estava em marcha o ciclo desenvolvimentista.

Para Benjamin, Darcy Ribeiro talvez tenha sido o maior profeta da civilização. "Inverteu radicalmente os velhos argumentos europeus contra nós, afirmando as vantagens da mestiçagem tropical diante de uma pretensa pureza temperada e fria". "Mostrou como, aos trancos e barrancos, conseguimos fazer um povo-novo a partir dos grupos humanos que o capitalismo mercantil encontrou neste território ou transplantou para cá”. Assim, “a composição ficava quase completa: éramos um país miscigenado, sentimental e alegre, moderno, culturalmente antropofágico, aberto ao outro e ao novo, desejoso de 
desenvolver-se, cheio de oportunidades diante de si. O passado nos condenava, mas o futuro nos redimia. A figura mítica do Macunaíma e a figura real de Garrincha - figuras fora dos padrões, que faziam tudo errado, para no fim dar tudo certo - nos divertiam e nos encorajavam".

A discussão sobre a formação social brasileira nos faz concordar com a síntese proposta por Benjamin. Para ele, "impõe-se, pois, uma dura luta política e cultural (...) temos que reencontrar uma ideia de Brasil ${ }^{82}$ (...) Por trás do poderio dos Estados Unidos, há uma ideia de Estados Unidos. Por trás da reconstrução do Japão, há uma ideia de Japão. Por trás da União Europeia, há uma ideia de Europa. Por trás da ascensão da China, há uma ideia de China".

"O esforço dos pensadores que nos antecederam deixou pontos de partida muito valiosos. Mas devemos reconhecer que eles nos falam de um país que, pelo menos em parte, deixou de existir". "Os elementos centrais com que eles trabalharam foram profundamente alterados nas últimas décadas" - a grande família patriarcal de Gilberto Freyre como espaço integrador; a incipiente urbanização de Sergio Buarque de Holanda; a revolução nos termos caiopradiano; a industrialização furtadiana.

O debate sobre a questão nacional brasileira é portanto, nosso ponto de chegada nesta sessão sobre a formação social brasileira e sua relação com a Grande Estratégia. Discutiremos a seguir O tema nacional, de Darc Costa.

O artigo é do início do governo Lula, momento em que todavia a força das preposições liberais que seguiram ao fim da guerra fria ainda eram absolutamente hegemônicas. Assim, Darc incia sua argumentação alertando para a existência de um processo de desqualificação do conceito de Nação e dos temas nacionais. Nesta visão então dominante, Nação passou a ter marca de passado, de pré-modernidade. Já a ação da potência dominante, os Estados Unidos, passara a ser vendida como de interesse universal, embora expresse o interesse nacional, seja ele econômico ou estratégico.

Na discussão sobre questão nacional, Darc Costa parte de Fichte - de quem recobramos as ideias mais importantes acima. Na sua interpretação da contribuição do autor alemão, Costa diz que "a questão da nação se coloca moderna no final do século XVIII. Um dos primeiros a tratar do tema foi o filosofo alemão Fichte, em seu Discurso à Nação Alemã,

\footnotetext{
82 Título retirado das memórias do Gen De Gaulle.
} 
onde, contrastando o "eu" germânico com o "eu" francês, apresentava, pelo viés da alteridade $^{83}$, a razão de ser da nação. O romantismo alemão e teses racistas do século XIX conduziram, neste século, a um aproximar do termo nação a possíveis grupamentos étnicos homogêneos".

Darc Costa repassa outras contribuições clássicas ao tema nacional. Como a de Benedict Anderson, que aborda nação como comunidade imaginada, localizando o aspecto linguístico o fundamento de sua criação - algo similar, como vimos, a posição de Fichte. Anderson localiza na América anticolonialista do século XVIII o espaço em que se funda o nacionalismo. Enquanto Hobsbawn e Xavier Guerra enxergam nação como um conceito particular à Europa, Ernest Gellner constrói sua teoria do nacionalismo relacionando-a ao fenômeno da industrialização e com os processos de homogeneização a ela associados.

Dando razão, como vimos, à visão da sociologia pós 1930, Darc Costa diz que o nacionalismo é uma manifestação política da homogeneidade cultural - entendida no sentido de uma lata cultura, não no sentido étnico -, uma cultura letrada, promovida pelo Estado.

Cabe também observar o sentido da frase de Hobsbawn, para quem "o nacionalismo vem antes das nações. As nações não formam os Estados e os nacionalismos, mas o oposto". Os episódios nativistas brasileiros que antecederam a independência de 1822 parecem dar razão a esta ideia.

Darc desta a contribuição do pensamento realista sobre política internacional, que ao colocar o interesse nacional como a razão de ser dos Estados nacionais, traz para o debate o tema da nação em sua versão estatal e contemporânea.

Darc trata de estabelecer, na sua visão sobre a questão nacional, um distinção com o marxismo. Para ele, "para nós, a nação é um sonho, fruto de um imaginário coletivo. Esta visão nunca foi aceita pelos marxistas" - apontando esta visão em Marx no prefácio à $2^{\mathrm{a}}$ edição d'O Capital. Diz ele que “...é o sonho que move os homens, e não a realidade, mesmo que este sonho seja o de comer. E o maior dos sonhos é aquele que transcende o homem e permeia o coletivo, o sonho de uma nação". Segundo Darc Costa “...não há o sonho de nação possível numa visão particular nem numa visão global ou universal. Nação pressupõe o coletivo".

\footnotetext{
${ }^{83}$ Situação, estado ou qualidade que se constitui através de relações de contraste, distinção, diferença.
} 
Talvez o autor traga uma leitura do marxismo que interprete numa chave excessivamente economicista ou materialista. Que veja pouco Hegel em Marx.

A seguir, Darc apresenta o conceito de Estado nacional. Citando Hobbes, observa que o homem vivia no "estado natural", concorrendo violentamente com seus semelhantes. Assim, para ele, a suprema revolução humana foi a constituição progressiva do Estado, algo que resultou de sucessivos pactos entre os homens.

Darc Costa propõe que as teorias de Estado possam ser agregadas em três tipos ideias, quanto a suas origens:

1 - A visão do contrato, preferida dos filósofos idealistas, diz que o Estado surge na obediência dos indivíduos, de forma voluntaria e perfeita, aos termos de um contrato que os favorece e que resulta de uma sucessão de pactos. O indivíduo prefere a solução da cooperação, que possui resultado superior a ação individualista competitiva ou pelo permanente conflito.

2 - A do contrato imposto. Aqui, a visão anterior é completada por um aprofundamento do estudo da natureza do contrato. A ideia é que alguns indivíduos consideram agir contrariamente ao contrato, pelo que, o controle desses indivíduos passa a ser objeto do próprio contrato. Esse contrato onde as regras são imposto é nomeada de Constituição.

3 - A da imposição contratual. Outros filósofos consideram que determinadas classes possuem o poder anteriormente à constituição do Estado; nesse caso, a Constituição resulta de uma outorga dos poderosos.

Segundo Darc, um Estado é "uma associação de indivíduos em que todos eles obedecem a regras definidas por alguém que toma as decisões sobre materiais de natureza coletiva e que obriga ao seu cumprimento".

Em linha com as considerações realista, que se viu no capítulo II, para Darc Costa, os Estados vivem num "estado natural” e há uma anarquia internacional; nestas, as mesmas mediações (estratégias) encontradas disponíveis para os indivíduos estão disponíveis aos Estados nacionais. Assim, as disputas, solucionam-se pela violência ou pela negociação. Numa definição relevante quanto ao que discutimos neste trabalho - o problema do Poder Nacional - é importante destacar que para o autor em análise, “[...] a finalidade de cada Estado é maximizar o bem estar de seus próprios cidadãos. Constatando-se a pluralidade 
dos Estados, podemos verificar que esse objetivo pode coincidir ou entrar em conflito com o objetivo de outros Estados [...]”.

Em tese, um Estado poderia adotar uma postura autárquica ou interativa. Na primeira, estabeleceria suas políticas com total independência dos demais Estados; na segunda, não teria vontade autônoma. Diz Darc que "no entanto, no mundo moderno não há espaço para relacionamentos que estejam nas duas posturas puras acima expostas (...) entre esses extremos existe um enorme espaço onde um Estado busca colocar-se. Na busca dessa posição, todos os Estados formulam sua estratégia nacional”.

Essa estratégia nacional - tema, aliás, de outra importante obra do autor - seria portanto, a busca de margem de manobra alargado no sistema internacional tendo em vista o objetivo primordial que vimos acima, o de maximizar o bem estar de seu povo.

Em seguida, Darc apresenta outra percepção teórica clássica nas ciências sociais, a de Max Webber, que busca a importância da burocracia na formação de um Estado nacional, aquela responsável pelos meio de coerção.

Nosso autor cita então Otto Hintze, para quem, "foi sobre o Exército Nacional que se constituíram os Estados da Europa Continental. Para ele, naqueles países, a formação do Exército é que transformou e determinou a estruturação dos mais remotos órgãos de Estado. Outros pesquisadores tem estado atentos à relação entre a centralização da coerção e as transformações sociais ocorridas no mundo. Clausewitz já dizia que a guerra, isto é, o emprego da força, era instrumento racional da política nacional. Não é novidade que a constituição dos Estados europeus decorreu da desmilitarização dos meios privados e da formação do monopólio da coerção em mãos do Estado absolutista que, em troca, concedia aos antigos senhores a manutenção de seus privilégios de posse e de suas honrarias, desde que apresentassem lealdade e submissão".

O Brasil também assistiu, nos eventos de expulsão dos holandeses em Guararapes, processo similar em que o Exército surgiu antes do Estado nacional e posteriormente, já no século XX, com a Revolução de 1930, viu a efetiva centralização da coerção pelo Estado, com a dissolução da milícias dos "coronéis".

Outra categoria central apresentada é a do interesse nacional, que,

“[...] deve ser visto como o somatório das aspirações permanentes e atuais que se criam e que se desenvolvem no processo histórico e que depende muito da característica do povo e de seu estágio de desenvolvimento econômico. Essas aspirações representam de forma 
subjetiva como os interesses estruturais e vitais do povo e do Estado nacional projetamse na consciência coletiva da nação e independem de diferenças regionais, de classe, de minorias étnicas, e, se não coincidem, não são incompatíveis, tendo um compromisso básicos sempre possível. As aspirações nacionais nascem dos esforços pela unidade nacional, pela comunidade e pela solidariedade política, econômica, social, religiosa e cultural. Surgem das lutas pela libertação nacional, que compreende a independência do domínio ou da interferência estrangeira e da liberdade interna contra forças internacionais ou derrogatórias da nação. Isto emana de manifesta originalidade, particularidade e individualidade próprias da gente e da terra, ou de suas características psicológicas e sociais. Irrompe do sentimento de distinção, que consiste na posse por elementos da comunidade, de certos atributos e qualidade visíveis na sua ação coletiva que a distingue de qualquer outra".

Aqui, as definições de Darc Costa claramente se apoiam nas construções geopolíticas brasileiras pretéritas sobre Poder Nacional, as quais revisamos no capitulo I.

Sobre o conceito de estratégia nacional, Darc diz que deve "estar calcada numa concepção e voltada para defesa do interesse nacional. A estratégia nacional é também um dos vértices de um triangulo indissociável que tem na política e no poder seus outros dois vértices. 'Estratégia nacional é a arte de aplicar o poder nacional para alcançar e preservar os objetivos nacionais, de acordo com a orientação estabelecida pela política nacional"”, diz ele, reproduzindo a visão clássica da Escola Superior de Guerra.

Darc Costa define nacionalismo como a defesa do interesse nacional. Busca defender as aspirações atuais e permanentes da nação, e, no fim, garantir dois objetivos: o bem estar do povo, seus direitos e suas garantias, $e$ a unidade política e a integridade territorial do Estado nacional.

Já a identidade nacional difere das demais identidade: religiosa, étnica, territorial, política ou mesmo humana. "É única. A identidade nacional estabelece-se sempre numa dialética: primeiro com a singularidade e depois com a alteridade"; ou seja, primeiro com características singulares daquele povo; depois, na sua relatividade em relação a outros. Fichte também caminharia por este percurso.

$* * *$

Numa segunda parte do texto então Darc Costa pergunta-se como esse arcabouço teórico se aplicaria ao Brasil?

Inicialmente, cabe ressaltar, para o autor, que o Brasil é a América portuguesa e que a independência brasileira é singular - algo já observado acima ao apresentar as teses de José Bonifácio. Diz o autor que a forma em que se quebraram os liames de Brasil e Portugal permitiu que a antiga burocracia permanecesse intacta em sua configuração - no 
que contrasta nossa independência com as demais ex-colônias espanholas, às quais, após longa turbulência política trouxe como consequência desorganização institucional e fragmentação territorial.

Esta é observação da mais alta relevância, uma vez que sustenta tese que no debate das ciências políticas é conhecido como a do transplante do Estado português - sendo este talvez o primeiro Estado europeu moderno.

Contudo, diz Darc Costa, a escravidão era poderoso obstáculo a modernização do Estado, mas era fortemente contestado seja em ameaças a própria unidade do território (federativas), como a guerra dos Farrapos, sejam as contestações sociais, como a Balaiada, dentre inúmeras outras.

Voltando ao que dissemos anteriormente, sobre a centralização do poder de coerção, Darc Costa lembra que o pacto entre as elites não aceitava o Exército Nacional, às quais preferiram a criação de uma Guarda Nacional. Assim, “o Estado nacional, no Brasil, iniciou-se por um processo de descentralização dos meios de coerção", no que se revelou, em nossa opinião, em fator de fragilidade ao longo do Império e da República Velha.

Para o autor. a gênese do Estado nacional brasileiro é singular e difere do que se acredita tenha acontecido na Europa. A forma brasílica foi resultado de uma aliança entre uma elite burocrática (letrada) e uma elite dos proprietários, sem esta, contudo, conceder os meios para impor a coerção a esta Elite burocrática. Aqui, a formação do Estado se deu pela manutenção da escravatura, na qual os proprietários mantiveram a capacidade de coerção direta, cabendo ao Império a condição de poder moderador nas disputas entre as oligarquias.

Assim, há um isolamento dos militares até a Guerra do Paraguai. Esta, contudo, até pela ameaça ao território brasileira à Oeste e por seu vulto, exigiu grande mobilização nacional. A invasão estrangeira, ameaçando a coesão do território, inaceitável, exigiu reação patriótica; "contudo, conjugar este discurso em uma sociedade escravocrata foi uma tarefa hercúlea", diz Darc. O organização do Exército para a guerra resultou dessa realidade sincrética, dificultadas pela doutrina europeia "cientifica" da época que defendiam a ideia da homogeneidade racial. Os atos de bravura assistidos pelos oficiais de seus subordinados, levariam mais tarde a contestação da monarquia e da ordem escravocrata que a apoiava. "Esboça-se no âmbito da força terrestre um projeto 
institucional para o país", lembra Darc numa observação interessante para uma projeto de investigação mais profundo sobre as raízes do pensamento pré-1930.

Com a República, após uma início promissor - o autor certamente se refere a Deodoro e Floriano -, numa década de contestação, o poder volta às mãos da velha oligarquia, reestabelecendo-se o antigo pacto das elites, agora sob o discurso dos interesses regionais: a República Velha.

Ainda assim, "o antigo projeto, formado no aparelho coercitivo do Estado, não morreu" Transmutou-se com o tempo e "surgiu de novo forte e pregador nos anos 1920", com o tenentismo.

A sequência do projeto nacional observou um período de 24 anos, entre 1930 e 1954, onde Getúlio Vargas exercia a polaridade - portanto um período que se deu com Vargas, sem Vargas e contra Vargas.

Para o autor, os antecedentes mais próximos à Revolução de 1930 encontramos em 1922: centenário da Independência, Semana de Arte Moderna em São Paulo, eclosão da revolta do Forte de Copacabana. Em seguida, a sistematização dessas ideias se deu num momento muito favorável da conjuntura internacional, tendo em vista que, ao fato de 1929 trazer efeitos devastadores para a economia brasileira, permitiu-se a formulação de um programa nacionalista.

A exemplo do que dissemos ao início deste capitulo, a introdução da ideia de planejamento governamental - consubstanciada em plano publicado em 1940 - teria grande importância. Da mesma forma que "a participação brasileira nos campos de batalha da Europa ensejou o reconhecimento de que a busca da autodeterminação e do desenvolvimento são objetivos da segurança nacional". Contudo, o curso do projeto nacional não se deu "sem sérios questionamentos técnicos, embates ideológicos e a ampla mobilização política" - quem retornar ao embate em torna da industrialização, entre Simonsen e Gudin, dará razão ao autor.

Para Darc Costa, o pensamento getulista e o tenentista de 1922 "compuseram sempre, desde 1930, o conjunto das forças dominantes na sociedade brasileira e fizeram-se representar dentro do aparelho de Estado, assumindo o papel preponderante de harmonizar os interesses econômicos em jogo, através de um implícito projeto nacional. É, pois, no arcabouço institucional montado e regido pelo Estado onde se definirão os 
chamados "interesses nacionais", que deveriam prevalecer sobre quaisquer outros formulados ou encaminhados por quem quer que seja".

A crise brasileira, iniciada em 1980, tem sua origem na perda de dinamismo da economia, após o longo ciclo nacional-desenvolvimentista. O ano de 1973, paradoxalmente marca ao mesmo tempo a crise mundial do petróleo e o maior crescimento da economia brasileira. Talvez como 2010 marcará, na situação brasileira recente, o auge do ciclo político liderado pelo PT e ao mesmo tempo o início da reverberação da crise internacional sobre os grandes países em desenvolvimento. Inversamente, como 1929 representou uma oportunidade para o programa emergido em 1930.

Na década de 1970, a crise do petróleo - ao que poderíamos agregar o fim do padrãoouro - gerou "a modificação dos preços relativos na economia mundial, que teve ali início, (e) trouxe consigo um profundo desequilíbrio nas contas nacionais". O Brasil não tinha estratégia preconcebida para a crise. Nos países mais desenvolvidos, a saída encontrada foi a de um ajuste recessivo. O Brasil fez outra opção e recorreu ao abundante capital externo existente, visando completar o ciclo de industrialização e de substituição de importações; o modelo de financiamento, contudo, provocou grande crescimento da dívida externa ${ }^{84}$ e aumentou a vulnerabilidade a choques externos. Interessante será observar estas lições da crise do início dos anos 1980 com as condicionante que levaram a crise brasileira contemporânea.

Tratou-se, na experiência do fim dos anos 1970, de um paradoxo: o projeto nacional visou minimizar a influência externa na economia brasileira, pela diversificação produtiva interna como defesa diante de choques produtivos externos. Por outro lado, contrariou-se profundamente essa ótica, endividando-se o país. Assi, recorda Darc Costa, "datam de 1975 os primeiros questionamentos quanto à estatização da economia”, seja quando ao papel do Estado na condução da crise, seja quanto a estabilidade da relação entre empresa estrangeira, empresa privada nacional e empresa estatal.

O retorno à democracia, contudo, "acabou levando a subjugação do projeto a seus detratores, a velha oligarquia proprietária e detentora de rendas. Questões resolvidas na década de 1950 e que não estavam mais à baila, voltam a pontuar o dia-a-dia das lides econômicas (...) Essas questões, que presenciaram sua solução em meados da década de 1950, voltam a incomodar e demostram a que ponto a questão financeira havia sido capaz

${ }^{84}$ Desta vez, da dívida interna. 
de desarticular o projeto nacional". Nas últimas duas décadas, "o projeto nacional foi dissolvido". Qualquer semelhança com a crise contemporânea não deverá deixar de ser observada.

Escrevendo o texto no início do governo Lula, Darc Costa diz que "o ponto de partida é a recuperação da credibilidade do país e de nossa autoestima”. Diz ele que, sendo o Brasil um grande país, deve-se buscar fortalecer a vontade nacional, recobrando a valorização do nacional e do nacionalismo, promover o amor ao país, à sua cultura, aos seus valores. Manter a estabilidade da moeda, elemento fundamental para a credibilidade governamental.

Dar Costa conclui que "é necessário recuperar-se a ideologia do desenvolvimento". Recorda ele que "[...] o projeto de nação e a defesa do tema nacional nunca foram o discurso mobilizador das elites proprietárias e de grande parte das elites letradas do Brasil. Foi e continua sendo o projeto do povo brasileiro, da parcela socialmente ascendente na burocracia de Estado, e que se apresenta tão bem nas Forças Armadas, e da classe média que vem se constituindo a duras penas no Brasil”.

$* * *$

Este capitulo 4 versou sobre a questão nacional, da identidade brasileira e da unidade nacional. Os autores e as ideias aqui apresentadas trazem lições importantes tendo em vista desafios da consecução de uma renovada e moderna Grande Estratégia de fortalecimento do Poder Nacional.

Na sessão seguinte observaremos diretamente os fundamentos da política de Defesa e os problemas do planejamento da agregação do potencial nacional. 


\title{
Capitulo V
}

\section{O planejamento da ampliação do potencial nacional e a Política de Defesa}

\begin{abstract}
"O Exército é um órgão essencialmente político; e a ele interessa, fundamentalmente, sob todos os aspectos, a política verdadeiramente nacional, de que emanam, até certo ponto, a doutrina e o potencial de guerra. A política geral, a política econômica, a política industrial e agrícola, o sistema de comunicações, a política internacional, todos os ramos da atividade, da produção e da existência coletiva, inclusive a instrução e a educação do povo, o regime político-social tudo, enfim afeta a política militar de um país"

(General Goés Monteiro, A Revolução de 30 e a finalidade política do Exército (Esboço histórico). Adersen Editores: Rio de Janeiro, s.d., p.133)
\end{abstract}

O que denominaremos planejamento da ampliação do potencial nacional é a consequência direta e aplicada da decisão do Estado nacional por buscar agregar capacidades em termos de Poder Nacional visando maximizar força no sistema internacional, tendo em vista a obtenção daqueles seus objetivos mais vitais até a totalidade dos objetivos nacionais permanentes.

Tendo em vista que o objetivo-fim deste planejamento é a busca de maximização de poder, podemos denomina-lo também como planejamento geopolítico nacional.

Como observa Miyamoto, a geopolítica "não se satisfaz apenas com a descrição física dos acidentes geográficos. A geopolítica se preocupa com a aplicação deste fatores na formulação de uma política visando principalmente fins estratégicos. Concebida sob este prisma a geopolítica é uma teoria de poder e visa sobretudo o preparo para a guerra" (1981, p.76).

Este planejamento decorre, antes que nada, da política nacional de Defesa - em sua dimensão mais alargada, como veremos. Mas também da política industrial, de ciência, tecnologia e inovação, e do planejamento de uma maior presença internacional do Brasil, em suas variadas dimensões. 
Neste capitulo, tendo como foco as chaves de planejamento estratégico de Defesa nacional, estabeleceremos diálogos deste com as variadas dimensões com a compõem, tendo em vista a Grande Estratégia e o Poder Nacional, nos termos em que estruturamos este trabalho.

Partiremos de uma resenha histórica da tradição brasileira de planejamento de objetivos de longo prazo, e nesta, destacaremos sua dimensão estratégica ou militar. Discutiremos os conceitos centrais que motivam as dimensões do planejamento, sobretudo o estratégico.

Uma segunda sessão deste capitulo problematizará uma das dimensões chave do Poder Nacional, àquela relativa a coesão nacional.

A terceira parte versará sobre a dimensão do desenvolvimento, que desde muito, estrutura um binômio do pensamento estratégico nacional.

Por fim, apresentaremos diversas facetas da definição basilar da doutrina brasileira contemporânea, a questão da dissuasão.

$* * *$

\section{Notas introdutórias sobre a planejamento estratégico do Poder Nacional}

O planejamento estratégico do Poder Nacional, ou ainda, a organização racional que busque agregar elementos que configuram condição de potência é a construção estratégica (como fazer) da aplicação de uma diretriz política de mais alto nível (o que fazer).

Questão chave nesta sistemática de planejamento nacional consiste na busca de maior autonomia e de maior autossuficiência em recursos de diversas naturezas, que caracterizarão elementos de poder da Nação. Esta busca por maior independência nacional se realiza por meio do planejamento tendo em vista a agregação de elementos de Poder Nacional. 
Antes de registrarmos um conjunto de plano e projetos de planejamento, cabe uma digressão introdutória de natureza histórica sobre momento chave em nossa trajetória nacional em que se desenharam projetos para o Brasil e nele se persistiu.

A existência de projetos articulados para a Nação, que politicamente ensejem um movimento tendo em vista maior emancipação nacional é pressuposto a existência de planejamento estratégico do Poder Nacional.

Afinal, o sentido de projeto nacional surge com o próprio surgimento da Nação independente. Povo-novo, fruto do amalgamento de três raças - elas mesmo já miscigenadas -, num vasto território colonizado a partir do que pode ser entendido como um primeiro movimento de globalização ${ }^{85}$, os brasileiros realizam sua transição para a independência de forma singular, preservando o Estado colonial como forma de preservar a então precária unidade política e territorial. Essa transição, que envolve continuidades e rupturas - marca, aliás, que perdurará por toda a trajetória -, terá como primeiro ato, a formulação de um ousado e progressista projeto de Nação por parte de José Bonifácio de Andrada e Silva.

O Projeto Andradino, pressupunha, antes que nada, a manutenção e a integração do Estado e do território nacional; a libertação dos escravos e o aldeamento dos índios; estabeleceu princípios sul-americanistas de nossa política externa ao definir uma estratégia de cooperação no âmbito do Rio da Prata; por fim, defendeu que "não se deveria esquecer de 'fomentar a indústria e as fábricas' do reino, pois a agricultura por si não basta e "sem indústria, sem fábrica e manufatura nenhum Estado é rico e independente" 86 . Voltaremos ao projeto de José Bonifácio mais adiante.

Afinal, derrotado o projeto andradino pelas elites agrárias escravocratas, o século XIX desemboca na efervescência de militares vitoriosos na Guerra do Paraguai, que sedentos de modernização e movidos pela ideia de progresso, inspirados na visão positivista, proclamam a República para pouco depois dar posse ao governo jacobinista de Floriano Peixoto. Em meio a pesadas turbulências políticas e militares - que vai da conspiração

\footnotetext{
${ }^{85}$ Refiro-me a epopeia representada pela construção de um vasto Império mundial, por um Estado das bordas geográficas da Europa (Portugal), que revolucionando as ciências marítimas e de navegação, realizaram a primeira expansão planejada da civilização ocidental pelo mundo.

${ }^{86}$ Ver Carmona, R. Bonifácio, gênese do pensamento nacional in Revista Tensões Mundiais. Fortaleza: Editora UECE, 2014.
} 
das elites paulistas à revolta da Armada -, Floriano chega a tentar tirar da gaveta o projeto proposto por José Bonifácio de transferir a capital federal para o Planalto Central. Deposto Floriano, reinicia-se um período, agora de três décadas, de domínio de elites agrária, agora, da República.

Podemos localizar no jacobinismo positivista dos militares combinado com uma revolução na interpretação sobre o Brasil ${ }^{87}$, a base de ideias que lograram deflagrar um longo ciclo de transformações nacional a partir da Revolução de 1930.

Como se vê na frase que está na epigrafe deste capitulo, o General Goés Monteiro, em livro de 1931, ao expressar os objetivos políticos da Revolução de 1930, abarca um conjunto de desafios que o novo regime perseguiria, a partir do poder militar, tendo em vista variadas questões do poder e da vida nacional.

O ciclo longo nacional-desenvolvimentista, justamente por sua duração, cerca de cinco décadas, foi heterogêneo e teve idas e vindas. Mas, para o que nos interessa aqui, registrou pelo menos três momentos de certa nitidez da tentativa de estruturar um projeto de Nação que buscasse maior autonomia nacional.

- Nos dois governo de Getúlio Vargas, que plantou fortes sementes da industrialização nacional, do planejamento de Estado e dos direitos dos trabalhadores;

- movidos pelas ideias do ISEB (Instituto Superior de Estudos Brasileiros), da Escola Superior de Guerra (ESG) e pelos remanescentes da assessoria econômica de Vargas, está o turbulento período que vai do governo Kubitschek, com seu modernizador Plano de Metas e a construção de Brasília até o governo João Goulart, onde se destacam a preponderância do planejamento, as reformas de base e a ideia da política externa independente (PEI);

\footnotetext{
${ }^{87}$ Nos referimos aqui, ao decidido enfrentamento à velha interpretação sociológica que preconizava a inviabilidade do Brasil e do seu povo dada a geografia e a mestiçagem. Gilberto Freyre, em especial, com Casa Grande e Senzala (1933), inverte a chave e vê na miscigenação uma virtude da civilização brasileira. O pensamento negativista sobre a nacionalidade porém, sobreviveria; deixaria traços, contudo, numa visão sociológica difundida a partir de São Paulo.
} 
- em grandes avanços na integração nacional e na aceleração da industrialização no período dos governos militares, especialmente com o II PND de Geisel.

O fim do ciclo nacional-desenvolvimentista e o início do ciclo da redemocratização, traria como virtude o coroamento de longa luta contra a ditadura e o descortinamento de lutas populares por direitos, há tanto represados, que se expressariam na Constituição de 1988. Mas também traria consigo prolongado período de incertezas e perda de rumo, de crise do projeto nacional, com o fim do consenso nacional a respeito de uma ideologia do desenvolvimento, que nos mobilizou por cinco décadas. Em setores da esquerda, aliás, é reanimada uma tensão com o desenvolvimentismo, ganhando influência uma visão antiEstado $^{88}$, em flerte com os liberais e com concepções que apregoavam enterrar a era Vargas.

Em seguida ao ciclo desenvolvimentista, seguiu um ciclo da redemocratização, que alongado, pode estar tendo seus estertores neste atual momento de crise brasileira.

A guisa de conclusão desta breve digressão, podemos dizer que duas lições ficam desta brevíssima introdução ao histórico dos projetos nacionais.

A primeira é que é constante e invariável em nossa trajetória histórica, que momentos de autonomia nacional sejam antagonizados fortemente por setores da burguesia mais pouco afeitos a ideia de nação e mais vinculados, ideológica e materialmente a interesses exógenos, resultando assim no truncamento da experiência. Como vimos, José Bonifácio, Floriano Peixoto, Getúlio Vargas, Ernesto Geisel e, mais recentemente, o ciclo Lula e Dilma sofreram dessa emboscada contra o interesse nacional.

O segunda questão que aflora é que a retomada do projeto nacional, após seu truncamento, ontem como hoje, exige a conformação de uma nova maioria nacional - política, econômica e social -, embalada por ideias, visões e intepretações do sentido da Nação e de suas potencialidades. Motivados pela ideias da independência e pela unidade do vasto território legado pelo português, surgiu o projeto andradino. Baseado na ideia positivista de progresso, na nova visão sociológica das virtudes da nacionalidade, no surgimento do Partido Comunista do Brasil e do próprio movimento modernista de 1922, emergiu 1930

\footnotetext{
${ }^{88}$ Ver, por exemplo, Fiori, J.L., O 'desenvolvimentismo de esquerda' e Desenvolvimentismo e dependência, respectivamente em 29/02/2012 e 28/03/2012, no Valor Econômico.
} 
e o desenvolvimentismo. Inspirados na ideia de esperança, que nos movesse a uma condição de país desenvolvido, democrático e com justiça social, vicejou o ciclo Lula/Dilma.

Feita esta contextualização, de momentos de auge do projeto nacional em nossa trajetória, cabe descrever um conjunto de planejamento posto em marcha ao longo desta trajetória - ou, mais exatamente a partir da inflexão causada em 1930.

Podemos dizer que o sistema de planejamento tendo em vista o desenvolvimento nacional toma corpo orgânico no Estado brasileiro sobretudo a partir da Revolução de 1930. Recordemos que antecedeu a 1930, um processo de reorganização das próprias Forças Armadas, no qual em colaboração com métodos modernos de organização militar à época (anos 1920), como na chamada missão militar francesa, deu-se um salto no tocante ao planejamento do uso e da organização das Forças.

A partir de 1930, estruturam-se então áreas relevantes no Estado brasileiro voltadas ao planejamento do desenvolvimento. No desafio de enfrentar a grave crise de 1929, organiza-se já no início do governo revolucionário o CFCEX (Conselho Federal de Comercio Exterior), que centraliza e organiza as trocas com o exterior de acordo com o interesse nacional, na forma de um plano de ação para a defesa da economia nacional. É quando o Estado brasileiro, num feito memorável, antecipando-se às teses de Jonh M. Keynes, estrutura uma exitosa política "keynesiana” antes de Keynes, de ação anticíclica que pode ser considerada, por seu ineditismo, um feito original na história econômica. Celso Furtado, em seu clássico Formação Econômica do Brasil (1958), identificou e valorizou este ineditismo na política quanto aos excedentes do café. Na ação anticíclica, o Estado brasileiro centralizou a regulação do preço do café e controlou o câmbio, como forma de racionar divisas e proteger a insipiente indústria nacional.

Submetidas à CFCEX, encontravam-se conselhos como o de Controle e Abastecimento, de Defesa Nacional e de Mobilização Econômica, que foram de suma importância sobretudo no contexto da segunda guerra mundial.

Ao final da segunda guerra outros dois órgãos surgiram, o Conselho Nacional de Política Industrial e Comercial (CNPIC) - onde se desenvolveu a controvérsia Simonsen - Gudin, sobre a industrialização brasileira, como veremos a frente - e, no âmbito do Conselho de Segurança Nacional, a CPE - Comissão de Planejamento Econômico. 
Outra iniciativa relevante do Estado brasileiro, no bojo da Revolução de 1930, foi a criação do DASP (Departamento Administrativo do Serviço Público) que profissionalizou a administração federal, possibilitando avançar no cumprimento de sua missão relativa ao planejamento do desenvolvimento nacional.

Nos anos 1950 uma nova leva de instituições viriam a ser criadas dando novas capacidades de planejamento do desenvolvimento do Estado brasileiro. A mais notável foi a criação do BNDE (Banco Nacional de Desenvolvimento Econômico), em 1952, durante o segundo governo do presidente Getúlio Vargas. Também é feito deste período de Vargas a criação da Eletrobrás e do Banco do Nordeste do Brasil, dentre outros mecanismos de planejamento. Estas iniciativas foram gestadas na Assessoria Econômica de Getúlio Vargas, compostas por brasileiros do quilate de Inácio Rangel e Romulo de Almeida, dentre outros ${ }^{89}$. Também se faz imperativo o registro, no período, da criação da CNEN (Comissão Nacional de Energia Nuclear), a partir do Almirante Álvaro Alberto e a estruturação do ITA (Instituto Tecnológico da Aeronáutica), pelo Brigadeiro Casemiro Montenegro - dois feitos estratégicos de longo prazo.

Antes, os técnico do DASP dão origem a um importante plano, denominado SALTE para Saúde, Alimentação, Transportes e Energia - durante o governo Dutra.

O governo de Juscelino Kubistchek (1956-1960) notabilizou-se por seu "Programa de Metas", que buscava enfrentar pontos de estrangulamento da economia, em especial em relação a infraestrutura e energia e a indústria de base - ainda que hoje seja lembrado mais pela introdução em larga escala da Industria automobilística multinacional no Brasil e pela construção de Brasília ${ }^{90}$.

Na sequência, o Brasil assistiu a formulação do Plano Trienal por Celso Furtado, durante a presidência de João Goulart - obstaculizado por um surto inflacionário e um crise política. Com o regime militar, se formula o Plano de Ação Econômica de Governo (PAEG) durante a presidência de Castelo Branco, ao que se seguiriam os Planos

89 Ver Os Boêmios Cívicos. A assessoria econômico-política de Vargas (1951-54), organizado pelo cientista político Marcos Costa Lima e editado pelo Centro Celso Furtado, 2013.

90 O Plano de Metas de JK é analisado por obra clássica de Carlos Lessa, 15 anos de política econômica. São Paulo, Brasiliense, 1982. 
Nacionais de Desenvolvimento, cuja primeira edição foi no governo de Médici e a o mais notável, sua segunda edição, já na presidência de Geisel, com o celebre II PND.

Podemos afirmar que este conjunto de planos relativos ao adensamento da capacidade nacional, coroaram o longo período nacional-desenvolvimentista entre 1930 e 1980 . Foi um período marcado pela centralidade de uma ideologia do desenvolvimento, que coesionou o país e permitiu transformações de fundo para a Nação e a nacionalidade. Voltaremos ao assunto mais a frente.

As décadas de 1980 e 1990 marcam período de crise e desorientação do projeto nacional. Em meio a transição do período militar para a democracia, ao surto inflacionário e a adoção de medidas liberais no plano da economia e do comercio exterior, o país limita seu planejamento e vive período de curtoprazismo na atividade governamental. As exceções são os planos plurianuais, exigência legal, que, contudo, não tem a força e consistência do planejamento realizado no período nacional-desenvolvimentista.

A partir do final dos anos 1990, ainda no governo de Fernando Henrique Cardoso, esboçase a constituição de planejamentos de mais longo prazo. É o caso do projeto "Brasil 2020”, elaborado em 1998 a partir da SAE (Secretaria de Assuntos Estratégicos) quando comandada pelo embaixador Ronaldo Mota Sardenberg, num exercício de reflexão e prospecção sobre o futuro do Brasil.

Já com o governo Lula, aparece novo exercício de reflexão para o longo prazo com o projeto Brasil em Três Tempos, que trabalha com a estruturação de metas com orizonte temporal de 2007 (fim daquele mandato presidencial), 2015 (quando o Brasil deveria haver cumprido as metas do milênio, propostas pela Organização das Nações Unidas) e 2022 (por ocasião do bicentenário da Independência nacional) ${ }^{91}$. Este plano é coordenado pelo então ministro Luís Gushiken com o suporte do Cel. Osvaldo Oliva, que traz o acumulo da metodologia de planejamento militar para a formulação das metas.

Já no final do segundo mandato da presidência de Lula, estrutura-se o projeto Brasil 2022. Coordenado pela SAE, pelo embaixador Samuel Pinheiro Guimaraes, discute-se cenários prospectivos para o Mundo, a América do Sul e o Brasil em 2022 e propõe-se um conjunto de Metas do Bicentenário a serem perseguidas pelo país ${ }^{92}$.

\footnotetext{
91 Ver Cadernos NAE 01, Presidência da República, 2004.

92 Ver Brasil 2022. SAE/Presidência da República, Brasília, 2010.
} 
Entre 2003 e 2014, um conjunto de planos setoriais marcaram a volta do planejamento como concepção de atuação Estado brasileiro. Em especial na área de Ciência, Tecnologia e Inovação e na área de Defesa - a qual trataremos com maior pormenor adiante - se destacam. Também reaparecem plano de política industrial. Mas o maior destaque, tendo em vista incidir diretamente sobre o planejamento do desenvolvimento do país no que diz respeito a infraestrutura, deve ser dado ao Plano de Aceleração do Crescimento (PAC), uma extensa carteira de obras em áreas como transporte, energia, habitação e saneamento, que entre 2007 e aproximadamente 2014 era monitorada e tinha priorizado seu financiamento por parte da Administração Central.

Em seu conjunto, podemos dizer que o sistema de planejamento do Estado brasileiro estruturado a partir de 1930 teve como sentido organizar o enfrentamento de gargalos visando ao adensamento do Poder Nacional visando maior autonomia do país no sistema internacional $^{93}$. Truncado em vários momento, como acima dissemos, podem ser analisados como uma lógica perene, de longo prazo na trajetória brasileira.

Nesse domínio da busca de autonomia nacional, segundo SPEKTOR (2014) há cinquenta anos, há um projeto básico, na forma de um consenso difuso ${ }^{94}$, que configuram um comportamento brasileiro nas relações internacionais. Nisto que neste trabalho estamos denominando como ideologia do desenvolvimento. Esta consiste em criar melhores condições para o desenvolvimento do capitalismo nacional - isto é, de elementos de Poder Nacional - que possibilite o aumento do "espaço de manobras" das elites nacionais.

Este projeto autonomista expressaria a própria identidade nacional, na forma de crenças e valores que constituiria a própria civilização brasileira. Também decorre da geografia, do porte da economia, das condições de Poder Nacional que o torna "o país-tipo da categoria dos países insatélitizáveis", segundo o chanceler brasileiro de Ernesto Geisel, Azeredo da Silveira (p.23).

\footnotetext{
${ }^{93}$ Para uma densa análise histórica sobre o planejamento nacional, ver $A$ intervenção do Estado no domínio econômico, de Alberto Venâncio Filho. Rio de Janeiro, Fundação Getulio Vargas, 1968.

${ }^{94}$ Ou abstrato, nas palavras do autor. Afinal, segundo ele, "na prática, as escolhas de política externa foram intensamente disputadas entre os próprios expoentes do autonomismo" (p.21). Para ele, "mesmo os governantes mais críticos do tradicional repertório autonomista - Fernando Collor de Mello - e Fernando Henrique Cardoso - adaptaram-lhe as características básicas sem desmontá-lo" (p.19).
} 
O projeto autonomista é lido no sistema internacional, isto é, por outras potencias, com enorme atenção, pois por suas características de grande país, eventual adensamento de elementos de Poder Nacional repercutirá sobre o próprio equilíbrio de poder. Assim,

\begin{abstract}
"Via de regra, terceiros países o interpretam como um programa mais profundamente revisionista do que sua enunciação sugere. Com intensidade crescente nos últimos anos, apareceram em cena argumentos a respeito da suposta ambição brasileira em minar as regras do jogo (como rising spoiler, na expressão de Radall Schweller) ou atuar para subverte-las (como irresponsible stakeholder, na expressão de Stewart Patrick). Isso ajuda a explicar por que "os Estados Unidos tem relutado em ungir a ascensão do Brasil"” (SPEKTOR, 2014, p.19-20).
\end{abstract}

A ideia de autonomia já havia sido apresentada no capitulo I, quando observamos, por exemplo, as fortes posições brasileiras contrarias ao congelamento do poder mundial, na expressão de Araújo Castro.

Passemos a examinar a dimensão militar da contribuição a estruturação do planejamento de longo prazo da agregação de Poder Nacional.

$* * *$

Dito isto, retornemos a identificação das contribuições da geopolítica brasileira ao planejamento da realizações das potencialidades nacional.

Observa-se uma contribuição contemporânea fundamental, todavia atual e vigente na sistemática de planejamento estratégico brasileiro são as formulações do General Golbery do Couto e Silva, conforme ressaltamos no primeiro capitulo deste trabalho.

Tomemos por base o chamado Anexo 1 de sua obra clássica, Geopolítica do Brasil (1967), denominada "Formulação de um conceito estratégico nacional (ensaio metodológico)".

Golbery fundamenta desta maneira a questão (1967, p.251);

"O Conceito Estratégico Nacional - C.E.N. - é a diretriz fundamental que, em dado período, deve nortear toda a estratégia da Nação, com vistas a consecução ou salvaguarda dos Objetivos Nacionais a despeito dos antagonismos que se manifestem ou possam a vir se manifestar-se, tanto no campo internacional, como até mesmo no âmbito interno do país.

Ora, em sentido amplo, a Estratégia de uma Nação confunde-se, conforme já vimos, com a própria Política de Segurança Nacional, responsável esta:

- de uma lado, pela preparação no devido tempo, e conveniente adequação do instrumento integral da ação estratégica - o Poder Nacional - mediante a elevação ou fortalecimento do Potencial da Nação e sua transformação oportuna em Poder efetivo;

- de outro lado, pela concepção e condução, em tempos de paz e durante a guerra, do conjunto de ações estratégicas visando, tanto no âmbito interno como no campo 
internacional, à superação ou neutralização dos antagonismos que se manifestem contra a consecução ou salvaguarda daqueles Objetivos nacionais"

Como podemos perceber, tendo em vista fundamentos exposto no primeiro capitulo deste trabalho, as preposições acima guardam grande atualidade com a sistemática contemporânea de preceitos geopolíticos e estratégicos quanto ao Poder Nacional.

A ideia de Conceito Estratégico Nacional, na visão acima, é muito mais que um planejamento de Força, no que diz respeito a doutrina e emprego do poder militar. Por sua definição enseja um conjuntos de atribuições que muito mais estão afeitas ao conceito de Grande Estratégia, no sentido de uma amplitude e dimensão.

Essencialmente, guarda relação com o que se denominou - por vezes, na academia, criticamente - como Doutrina de Segurança Nacional. As origens desta, contudo, são bastante mais remotas. A contribuição do General Golbery está no sentido de aprimorála conceitualmente e trazê-la para o presente - neste caso, no período inicial dos governos militares.

Rigorosamente, como dissemos acima, as bases da visão relaciona à missão das Forças Armadas num país com as características do Brasil podem ser observadas em formulações pré-1930 - que a rigor, foram a base de ideias do período longo iniciado em 1930.

Como vimos, data de 1931, a visão exposta pelo General Goés Monteiro sobre a Finalidade Política do Exército, que fundamentou e deu corpo a Doutrina de Segurança Nacional.

Com uma visão totalizante, quanto aos desafios da construção nacional, estruturou-se uma visão perene, subjacente até nossos dias, da política de Defesa como parte constitutiva de um estratégia geral - ou grande estratégia - para o país. Desta visão sobre a missão das Forças, depreende-se a explicação da DSN por praticar a política do Exército e não a política do Exército. Trata-se aqui da viragem produzida especialmente na segunda década do século XX no sentido de uma maior profissionalização de um Exército até então excessivo bacharelismo - herdado da tradição positivista-e com baixa assimilação conceitual e operacional das ciências militares mais modernas.

É exagerada e unilateral a visão corrente em muitos setores da academia, que a Escola Superior de Guerra (ESG) teria surgido como esteio da influência norte-americana sob as Forças Armadas brasileiras no pós-segunda guerra mundial. Nas palavras do General Meira Mattos, celebre geopolítico brasileiro, 
"Em 1949, com a criação da Escola Superior de Guerra, o pensamento político brasileiro começou a se estruturar em bases realísticas e científicas. É a ESG responsável por uma doutrina política essencialmente brasileira, fundamentada na dinâmica da aplicação do poder nacional. Assentada na relação de mutua causalidade entre Segurança e Desenvolvimento, a doutrina defendida pela ESG durante mais de um quarto de século, fundamenta-se, essencialmente, no levantamento dos objetivos nacionais permanentes e objetivos nacionais atuais, e na formulação de uma política para alcança-lo" (1975, p.60).

O pensamento político e estratégico brasileiro "em todo momento a relação conviveu com frieza e distanciamento, nunca havendo coordenação estrita entre políticas externas um e outro país", segundo Spektor. O autor identifica "uma postura brasileira de crítica ao internacionalismo liberal (que) manteve-se intocada durante a guinada liberal do sistema político brasileiros com o fim do regime militar". Mesmo os presidentes mais identificados com uma agenda liberalizante (Collor e Fernando Henrique), souberam "guardar algum grau de distanciamento" (2014, p.25-26) - a postura final do governo de Fernando Henrique, na Cúpula de Québec, em dizer que ALCA (Área de Livre Comércio das Américas) era uma opção - e não um destino - é indicador disto.

Um exemplo do uso da autonomia no sistema internacional, nos é dado por Oliveiros Ferreira, segundo quem,

“[...] no passado, sempre houve no círculo dos que realmente decidem, a preocupação de fazer que o Brasil palmilhasse os tortuosos caminhos da pesquisa nuclear e da tecnologia de mísseis com o objetivo de alterar qualitativamente o posicionamento do Brasil no concerto das nações. A condição para a realização desta política era que o país não estivesse atado a nenhum tratado internacional que limitasse sua capacidade de pesquisa nesses campos considerados 'sensíveis' pelas duas superpotências da época - Estados Unidos e União Soviética” (2001, p.21).

Breve revisão do curso do pensamento estratégico brasileiro contemporâneo: as políticas de Defesa

Como vimos anteriormente, o sistema de planejamento do desenvolvimento brasileiro guarda raiz na sistemática de planejamento militar. O ciclo longo desenvolvimentista foi a experiência exitosa de transformação estrutural da economia brasileira e de adensamento do Poder nacional que comprovou o acerto desta contribuição.

A estruturação da Escola Superior de Guerra em 1949 é um marco deste planejamento da agregação do potencial nacional. É neste espaço que desde seu surgimento se endogenizam conceitos - como o de Poder Nacional - e se estabelecem sistemáticas e metodologias de planejamento de longo prazo. 
É preciso, como introdução a questão, observar que historicamente, dada as caraterísticas do Brasil, de formação territorial e étnica recentes, e de insuficiente - todavia até hoje integração geoeconômica, as Forças Armadas sempre se defrontaram com uma dupla missão, uma de natureza endógena, outra exógena.

À sua função precípua - manter a inviolabilidade e a integridade territorial e a salvaguarda do poder político e econômico do pais, tendo em vista outros atores do sistema internacional -, para as Forças Armadas soma-se uma missão de natureza endógena: ajudar na construção nacional, na integração do território e na preservação e fomento dos valores da nacionalidade.

Esta dupla missão nem sempre, historicamente, observou seu ponto ótimo. Por longo período, sobretudo entre o final da segunda guerra mundial e os anos 1970, nossas três Forças sofreram as injunções derivadas da clivagem da guerra fria. A vinculação acrítica - ainda que não absoluta, como veremos abaixo - à dinâmica ideológica hemisférica, limitou o papel autônomo das Forças Armadas no estabelecimento de um doutrina brasílica.

Primeiro, por serem Forças autônomas, conformando estruturas sem dialogo operacional, cada qual cuidando de sua parte numa divisão de trabalho. Como observa Marques, tínhamos "um Exército de ocupação, uma Marinha voltada para a guerra antissubmarino e uma Aeronáutica cuja principal preocupação era administrar o complexo industrial do setor aéreo" (2001, p. 52).

O período entre os anos 1970 e o fim da guerra fria, trariam às Forças redefinições geopolíticas com profundas consequências operacionais e ganhos de autonomia estratégica. Em grande medida foram movimentos que permitiriam o salto qualitativo no pensamento estratégico brasileiro contemporâneo.

No caso da Marinha, este processo de revisão do seu papel estratégico começou com uma reavaliação da aliança iniciada com a vinda da Missão Naval americana de 1922, e mais especialmente, com o papel a ela conferido no contexto da guerra fria, como dito, de concentrar-se na presença submarina soviética em sua costa atlântica. A assinatura do Acordo Nuclear com a Alemanha (junho de 1975), pode ser considerado o ponto de viragem para uma maior autonomia, visando o objetivo de longo prazo - o qual, neste 2017, estamos há poucos passos de completar - de obtenção de um Submarino a propulsão nuclear no qual tivéssemos capacidade de projeta-lo e construí-lo. 
Pode-se dizer que a primeira grande experiência brasileira na busca por obter autonomia de projeção e produção de equipamento militar pode ser localizada no governo do presidente Ernesto Geisel, quando ocorre a ruptura do acordo militar Brasil - Estados Unidos $(1977)^{95}$ e o fortalecimento, de pelo menos três empresas que se constituiriam em pilares da base industrial de Defesa brasileira: a Embraer - encubada no Instituto Tecnológico da Aeronáutica (ITA) -, a Engesa, fabricante de veículos blindados e carros de combate, e a Avibras, focada em artilharia e sistemas de defesa aéreos, foguetes e mísseis. Também neste período, em tema que nos interessa diretamente no que diz respeito à Armada, é que surge o Programa Nuclear da Marinha (PNM), em 1979, cujo objetivo essencial é dominar o ciclo completo do combustível nuclear visando a produção de um reator de Submarino. O PNM, aliás, é resultado direto do bloqueio tecnológico norte-americano da venda de tecnologia de ultracentrifugação previsto no acordo nuclear firmado com a Alemanha em 1975.

No caso especifico da Marinha do Brasil, o descontentamento com a subordinação material a equipamento norte-americano vinha já desde os anos 60, sobretudo "pela resistência dos EUA em fornecer qualquer tipo de armamento às marinhas do hemisfério, que extrapolasse as missões previstas para essas forças navais nos quadros da guerra fria", isto é, tarefas de proteção antissubmarino do trafego marítimo, segundo o almirante Armando Amorim Ferreira Vidigal ${ }^{96}$.

O Exército brasileiro também realizou uma importante atualização de seu pensamento estratégico a partir da denúncia do Acordo militar com os Estados Unidos em 1977. Na visão de Martins Filho, "embora o Exército não tenha colocado no centro de suas perspectivas estratégicas a busca de maior autonomia diante dos Estados Unidos, a

\footnotetext{
95 Um fato estratégico expressivo, fruto do entendimento que este Acordo, de 1952, que embutia o programa de assistência militar, não mais atendia às necessidades das Forças. Desde a segunda guerra mundial, os Estados Unidos passam a influenciar fortemente as Forças Armadas brasileiras, quer no aspecto geopolítico, relativo a visão de mundo, quer no aspecto material, tornando-se o grande fornecedor de equipamento militar. No plano das ideias, o pensamento estratégico incorpora a leitura da "defesa da civilização ocidental" e da identificação do inimigo comunista - quer no plano externo, quer no plano interno (inimigo interno) -, como objeto a ser combatido. Simbolizam essa visão de mundo, aspectos basilares da elaboração geopolítica do general Golbery e a própria fundação da Escola Superior de Guerra (ESG). No plano material, Como admite documento recente do Exército Brasileiro, "passamos a adotar um pensamento militar com relativa autonomia somente a partir dos anos 1980, quando adotaram-se conceitos próprios e promoveu-se o fortalecimento da indústria nacional de defesa" - ver "O processo de transformação do Exército", $3^{a}$ edição, disponível em www.exercito.gov.br
}

96 Ver Martins Filho, J. R. "As Forças Armadas brasileiras no pós-guerra fria", disponível em http://www.tensoesmundiais.net/index.php/tm 
intenção de construção de potência trazia inevitavelmente na mesa a necessidade de desenvolver a capacidade estratégica brasileira e de diminuir suas vulnerabilidades" 2006, p.85). Assim, a hipótese de Martins Filha é que a busca de autonomia deveu-se mais pela busca de maior autonomia em tecnologia militar. Quem observar o desenvolvimento da Engesa e da Avibrás a partir de então, dará razão ao autor.

Aspecto fundamental para a atualização do pensamento estratégico foi a percepção pelo Exército, a partir da guerra das Malvinas (1982), da "incapacidade das Forças Armadas brasileiras para uma guerra convencional de média intensidade" (Cavagnari Filho apud Martins Filho, 2006, p.88). Ou seja, os anos de estreito vinculo material e doutrinário com as Forças Armadas norte-americanas havia deixada vulnerabilidade estratégica importante no que diz respeito a missão precípua da Força: a defesa da inviolabilidade e integridade da nação.

Além disso, a guerra das Malvinas supultava de vez ilusões quanto ao guarda-chuva hemisférico - que remanescente da Doutrina Monroe, efetivou-se no TIAR (Tratado Interamericano de Assistência Reciproca), de 1947, segundo o qual haveria uma solidariedade hemisférica caso da agressão de uma potência extra regional. Desenhado sob medida para uma geopolítica da contenção do comunismo, contudo, não resistiu a agressão da potência anglo-saxã europeia à Argentina - país, aliás, com o qual durante a guerra fria, a cooperação internacional de Washington "foi muito mais intensa (...) que com o suposto aliado Brasil” (SPEKTOR, 2014, P.26).

Um último fator determinante para um reposicionamento estratégico do Exército, num sentido de maior autonomia, foram as tendências que se estabeleceram no início dos anos 1990, com o fim da guerra fria e a proclamação do fim da história com a instauração da ordem internacional liberal sob a hegemonia unipolar norte-americana. Em especial, a relativização da soberania nacional e territorial, aliado a sinal inequívocos de nova corrida por recurso naturais levou a deslocamento do foco geoestratégico do Exército da região do Prata para a Amazônia brasileira.

Com isso, alteração doutrinaria de fundo se estabeleceu na Força Terrestre. Aos poucos, foi se abandonando a hipótese de guerra centrada numa fricção com a Argentina - que exigia a constituição de poderosas forças de cavalaria, artilharia e infantaria ao longo da fronteira sul, especialmente no Rio Grande do Sul. Em seu lugar, a hipótese de guerra ou de emprego predominantemente passou a se dar no ambiente amazônico, no qual o Brasil 
se defrontaria com um potência (ou uma coalizão de potencias) extra regionais que ameaçassem sua soberania sobre a Hileia.

Observando a experiência de guerra assimétrica na história militar recente, tanto ocorrida no Brasil - especialmente no longo combate a Guerrilha do Araguaia (1973-1975) -, quanto externa - com o estudo de princípios de guerra revolucionaria chinês (Mao) e vietcongue - buscou-se a formulação de uma Doutrina de resistência - que bebeu, ademais, da doutrina brasílica de guerra, demonstrado em diversos episódios de nossa história e ao qual voltaremos mais adiante.

A Força Aérea brasileira foi a força que talvez mais tenha mantido uma linha de relativa continuidade no pensamento estratégico. Força mais recente (1944) e menor, dedicada a esforços de atender e integrar pelas visa aéreas o país-continente, contudo, sempre foi uma forças tecnológica, que desde cedo teve que constituir capacidade de alguma autonomia tendo em vista as caixas-pretas que sempre constituíram artefatos aéreos. $\mathrm{O}$ esforço do Brigadeiro Casemiro Montenegro em constituir o Instituto Tecnológico da Aeronáutico, a posterior surgimento da EMBRAER e as necessidade imperativas de desenvolvimento do Programa Espacial Brasileiro - tendo em vista o domínio do imenso território nacional - sempre constituíram incentivos poderosos a manutenção de alguma autônoma tecnológica, mesmo nos momentos de maior polarização estratégica do Brasil por parte da geopolítica da guerra fria.

A ruptura do acordo militar com os Estados Unidos em 1977 iniciou uma nova fase no pensamento estratégico brasileiro que só se completaria, a nosso ver, com a edição do primeiro documento público sobre o tema: a Política de Defesa Nacional (PDN), de 1996, ainda no primeiro mandato de Fernando Henrique Cardoso.

A ruptura de 1977 com o acordo militar com os Estados Unidos de 1952, mas palavras do Almirante Mario César Flores, ex-ministro da Marinha, "nos condicionou doutrinaria e materialmente por praticamente 30 anos" (in ALMEIDA PINTO, 2004, p.33).

Busquemos agora examinar os documento de Defesa nacional para neles identificar traços desta evolução do pensamento estratégico que buscamos desenvolver acima.

O primeiro documento que podemos denominar como sendo sobre "defesa nacional", segundo nossa pesquisa consegue alcançar, é texto classificado como "ultra-secreto" emitido pela Estado-Maior das Forças Armadas (EMFA) em março de 1969, denominado 
“Conceito Estratégico Nacional”. Aqui observa-se cabal e integralmente a assimilação, que conceitual quer mesmo literal, da proposição do General Golbery do Couto e Silva formulada dois anos antes em Geopolítica do Brasil. O documento conheceu uma segunda edição em 1974, texto que utilizaremos para efeito deste comentário.

O CEN é produto direto da metodologia e da conceituação formulada no âmbito da Escola Superior de Guerra. Está dividido em duas partes. A primeira, é uma "síntese da avaliação política conjuntura". O segundo, versa essencialmente sobre as hipóteses de guerra, isto é, as possibilidades de emprego das Forças Armadas a partir da análise de conjuntura.

Contudo, o curso da evolução do pensamento estratégico brasileiro poderá se ternar mais perceptível com a edição da citada Política de Defesa Nacional de 1996. Esta fecha um certo ciclo, aberto em 1977 e que se estendeu duas décadas tendo em vista ambiente de absoluta incerteza que caracterizou tanto o plano interno como a situação internacional. Afinal, foi o período, internamente, da transição entre o governo militar e a Constituição de 1988, seguida de período de continuidade da instabilidade derivado da eleição peculiar, pelo voto direto de um novo presidente da República, Fernando Collor de Mello - com uma política relativamente hostil aos interesses nacionais e estratégicos, seguido pelo impeachment e a interinidade de Itamar Franco.

A partir do Plano Real (1994) e a eleição do Fernando Henrique Cardoso previa-se um período de maior estabilização. Mas o deslumbramento inicial do novo presidente brasileiro com a globalização e sua política explicitamente liberal do primeiro período, impediam movimentos de maior afirmação nacional. A própria PDN de 1996 pode ser considerada, neste sentido, um ponto fora da curva, pois aparecera num momento de fraca iniciativa estratégica do Brasil. Podemos dizer que seu aparecimento se relacionava com outra prioridade do período FHC, objeto de controvérsia estratégica então, que foi a criação do Ministério da Defesa (MD), em 1999.

A PDN pode ser lida como movimento para diminuir as resistências a criação do MD enxergado por muitos na comunidade de pensamento estratégico como algo afeito a linha de enfraquecimento das Forças Armadas no bojo da política de diminuição do Estado e adesão entusiasmada à globalização.

Não obstante, o texto da PDN - 1996 traz importantes questões. 
A primeira definição da PDN refere-se a seu escopo, assim definido: "a Política de Defesa Nacional, voltada para ameaças externas, tem por finalidade fixar os objetivos para a defesa da Nação, bem como orientar o preparo e o emprego da capacitação nacional, em todos os níveis e esferas de poder, e com o envolvimento dos setores civil e militar" (item $1.3)$.

Voltada a "ameaças externas" - que seguiam existindo, apesar de ter sido escrita poucos anos depois da euforia liberal de 1989-1991, com a derrota e dissolução da União Soviética -, e seguindo a tradição de planejamento militar brasileira clássica, propunha, para enfrenta-las, propunha que a tarefa de defesa da Nação não se restringia a esfera militar estritamente, mas a "odos os níveis e esferas de poder".

Defrontando-se com um mundo cambiante, onde se alteravam os paradigmas existentes desde o fim da segunda guerra mundial, o texto definia que "o término da Guerra Fria tornou obsoletas as generalizações simplificadoras decorrentes da bipolaridade ideológica e militar, ate então vigente. Atualmente, apesar e serem reduzidos os riscos de um confronto nuclear em escala planetária, desapareceu a relativa previsibilidade estratégica" (item 2.2).

Nesta definição, deixava-se claro que uma das colunas vertebrais da geopolítica brasileira da guerra fria - a vinculação ao esquema do guarda-chuva hemisférico anticomunista - havia ruído. Assim, reconhecia-se que havia um "fase de transição, em que se estabelecem novas regras políticas e econômicas de convivência entre as nações, caracterizada pela ausência de paradigmas claros" (item 2.4). Nesse contexto, o Brasil estava chamado a reforçar seu pensamento estratégico autóctone.

A PDN de 1996 também define inicia a definição de conceito que depois seria chamado de entorno estratégico. Diz o texto que "para o Brasil, país de diferentes regiões internas e de diversificado perfil, ao mesmo tempo amazônico, atlântico, platino e do Cone Sul, a concepção do espaço regional extrapola a massa continental sul-americana e inclui, também, o Atlântico Sul” (item 2.7). Assim, ao "extrapolar" a massa continental terrestre e abarcar o Atlântico Sul, começa um movimento, que seguiria, de alargamento dos objetivos geoestratégicos brasileiros.

Estas definições também deitam raiz nas características geográficas do país, que nos legou um território misto ou anfíbio - como disse o primeiro mestre da geopolítica brasílica, coronel Mario Travassos. Ao Brasil, a contradição básica expressa nos clássicos da 
geopolítica - a disjuntiva entre o poder naval de Mahan e o poder terrestre de Mackindernão se apresenta. Ao contrário, nosso território exige atenção, a um só tempo, às suas duas vertentes geográficas, às suas "duas amazônias": a verde e a azul - sendo esta última assim denominada pela importância central do Atlântico Sul para os brasileiros.

Em alguma medida, pode-se dizer, a concepção realista e geopolítica subjacente à PDN, contrastava com a orientação do governo Fernando Henrique, que em sua primeira fase (1996 é o segundo ano do primeiro mandato) nutria entusiasmo pela globalização. Mas sobretudo a PDN busca iniciar uma leitura nova que permita a atualização do pensamento estratégico sem cair nas armadilhas liberais contemplativas da unipolaridade norteamericana.

Os passos seguintes de atualização do pensamento estratégico brasileiro viriam com o governo do presidente Lula. A partir de setembro de 2003, até meados de 2004, o Ministério da Defesa realiza uma série de oito rodadas de debates numa organização militar localizada em Itaipava (RJ), que resultariam em subsídios importantes para a nova Política de Defesa Nacional, que viria a público em 2005. Os resultados destes debate em Itaipava foram publicados em quatro tomos denominados "Reflexões sobre defesa e segurança: uma estratégia para o Brasil”.

A PDN de 2005, além de reafirmar o texto de 1996 que se destina ao enfrentamento de ameaças externas, deixa mais nítido certos conceitos, dando mais nitidez a definições conceituais estratégicas, sem, contudo, abandonar a vertebra da tradicional metodologia de planejamento em Defesa nacional. Já em sua introdução, diz que "é composta por uma parte política, que contempla os conceitos, os ambientes internacional e nacional e os objetivos da defesa. Outra parte, de estratégia, engloba as orientações e diretrizes", mantendo portanto, a relação hierárquica própria do pensamento estratégico - desde Clausewitz, pelo menos - da relação hierárquica de subordinação entre política e estratégia.

A seguir, ainda na introdução da versão de 2005, apresenta-se conceito-chave que define que, ao contrário da visão liberal idílica, o país defronta-se com ameaças externas. Diz o texto;

“Após um longo período sem que o Brasil participe de conflitos que afetem diretamente o território nacional, a percepção das ameaças está desvanecida para muitos brasileiros. Porém, é imprudente imaginar que um país com o potencial do Brasil não tenha disputas ou antagonismos ao buscar alcançar seus legítimos interesses. Um dos 
propósitos da Política de Defesa Nacional é conscientizar todos os segmentos da sociedade brasileira de que a defesa da Nação é um dever de todos os brasileiros"

Tem grande relevância para a redefinição de nosso pensamento estratégico esta ideia força acima, por nós negritada. De escopo nitidamente realista, pode ser lida pela chave em que o país, ao perseguir o desenvolvimento do seu Poder Nacional, se defrontará com antagonismos.

Este item deve ser complementado por um seguinte, que define que "neste século, poderão ser intensificadas disputas por áreas marítimas, pelo domínio aeroespacial e por fontes de água doce e de energia, cada vez mais escassas. Tais questões poderão levar a ingerências em assuntos internos, configurando quadros de conflito" (item 2.1). Aqui também se dá um passo adiante, ao nomear interesses exógenos pelos quais o país poderá ser confrontado, introduzindo a questão dos recursos naturais estratégicos - agua doce e energia.

Outro item (1.3), observa que,

"Gradualmente, o conceito de segurança foi ampliado, abrangendo os campos político, militar, econômico, social, ambiental e outros. Entretanto, a defesa externa permanece como papel primordial das Forças Armadas no âmbito interestatal. As medidas que visam à segurança são de largo espectro, envolvendo, além da defesa externa: defesa civil; segurança pública; políticas econômicas, de saúde, educacionais, ambientais e outras áreas, muitas das quais não são tratadas por meio dos instrumentos político-militares.

Ou seja, aqui se refere ao alargamento do escopo de temas que tem dimensão securitária.

Dá-se novo passo na definição geográfica de áreas de interesse nacional, com o aparecimento do conceito de entorno estratégico. Diz o texto que "o País visualiza um entorno estratégico que extrapola a massa do subcontinente e incluiu a projeção pela fronteira do Atlântico Sul e os países lindeiros da África” (item 3.1). A seguir, observase que "O Brasil atribui prioridade aos países da América do Sul e da África, em especial aos da África Austral e aos de língua portuguesa, buscando aprofundar seus laços com esses países" (item 4.9).

Tem grande relevância a introdução deste conceito pela política de Defesa ${ }^{97}$. A delimitação aqui apresentada possui claros traços de ineditismo. Para José Luís Fiori

\footnotetext{
${ }^{97}$ Ainda que se possa ponderar que uma definição inicial de entorno estratégico - sem o uso deste conceito - pode ser localizada na própria Constituição da República, promulgada em 1988, que, já nos seus princípios fundamentais, em parágrafo único, determina que "A República Federativa do Brasil buscará a integração econômica, política, social e cultural dos povos da América Latina, visando à formação de uma comunidade latino-americana de nações".
} 
(2013, p.32), com isso se "propõe um conceito novo e revolucionário na história brasileira: o conceito de 'entorno estratégico' do país, a região onde o país quer irradiar - preferencialmente - sua influência e sua liderança diplomática, econômica e militar...”. Voltaremos ao tema noutra parte deste trabalho.

Por fim, nesta breve apresentação da PDN de 2005, cabe destacar a ideia que "A vertente reativa da defesa, no caso de ocorrer agressão ao País, empregará todo o poder nacional, com ênfase na expressão militar, exercendo o direito de legítima defesa previsto na Carta da ONU (item 6.3)". Reapresenta-se aqui um conceito clássico, relativo ao uso do conjunto dos instrumento do Poder Nacional tendo em vista os objetivos de Defesa.

A seguir, cabe destacar novo momento que é o aparecimento de um segundo documento, que desdobra a política, denominado Estratégia Nacional de Defesa (END), no ano de 2008. Trata-se, a nosso ver, do ponto de vista conceitual, de um verdadeiro ponto de inflexão para a Grande Estratégia brasileira.

Antes que nada, pelo contexto. O ano de 2007, quando é constituído grupo de trabalho para a elaboração de documento, primeiro mandato de Lula reeleito, é também o ano em que, no imaginário nacional, o país caminha para a condição de potência no sistema internacional. A política externa "altiva e ativa" do chanceler Celso Amorim e o prestigio internacional do presidente Lula dão aos brasileiros a sensação de que a grandeza nacional vai finalmente se realizando.

Neste mesmo 2007, o presidente Lula estabelece a decisão de revitalizar o projeto do submarino nuclear e o Programa Nuclear da Marinha. Em 10 de julho de 2007, o presidente Lula visita o Centro Experimental de Aramar, em Iperó (SP), base do Programa Nuclear da Marinha. Convencido da importância altamente estratégica para o Brasil, Lula decide ali mesmo liberar recursos que revigoram o Programa - que se encontrava em estado vegetativo praticamente desde a literal pá de cal que o então presidente Collor jogara na Serra do Cachimbo, simbolizando o enterro de nosso programa nuclear em 1991.

Pouco depois, em novembro de 2007, a Petrobras informou à Agência Nacional de Petróleo (ANP) e ao Conselho Nacional de Política Energética (CNPE) que seus estudos geológicos indicavam a existência de grande potencial petrolífero na Plataforma Continental, em uma área de $149 \mathrm{mil} \mathrm{km}^{2}$, que se estende do litoral do Espírito Santo ao de Santa Catarina. Era o aparecimento do Pré-Sal. Com ele, a decisão de revigorar o 
programa visando a obtenção do submarino nuclear fica mais nítido em função da necessidade de proteção das reservas petrolíferas brasileiras.

Em janeiro de 2008, o então ministro da Defesa, Nelson Jobim, em visita à França, vai a base naval de Toulon. Nesta ocasião, desenvolve tratativas importantes relativa a uma possível cooperação com este país.

Fruto do revigoramento do PNM, decidido em 2007, em setembro de 2008, a Marinha ativa a Cogesn - Coordenadoria Geral do Programa de Desenvolvimento de Submarino com Propulsão Nuclear (Cogesn), com objetivo de gerenciar o projeto e a construção do estaleiro, da base e do submarino.

Por fim, no mês de dezembro, ao mesmo tempo em que é promulgada a nova Estratégia Nacional de Defesa - ponto de inflexão estratégico na visão geopolítica brasileira - ocorre a visita do presidente francês Nicolas Sarkozy, com o qual se assinam importantes acordos, inclusive no campo militar. Tem-se início assim, as negociações que resultariam, nove meses depois, na assinatura do PROSUB, em setembro de 2009.

Esse resgate do contexto das movimentações estratégicas de 2007-2008 são importantes para corroborar a ideia de ponto de inflexão. A ideia do submarino a propulsão nuclear para proteger aquilo que no imaginário nacional seria nosso bilhete premiado para um futuro de grandeza - o pré-sal - simbolizava uma definitiva viragem no pensamento estratégico, deixando para trás a parte obsoleta da geopolítica nacional - a ilusão da proteção hemisférica da guerra fria - e valoriza a parte atualíssima deste pensamento - a agregação de Poder Nacional.

As ideias da PDN 2005 e da END 2008 seriam reafirmadas na sua atualização de 2012, já sob o comando de Celso Amorim à frente do Ministério da Defesa, na qual se agregaria um terceiro documento: o Livro Branco de Defesa Nacional, que ao lado da agora Política Nacional de Defesa e da Estratégia Nacional de Defesa, passariam a conformar uma tríade de documentos estratégico do país.

Nesse período de pouco mais de uma década - que vai dos debates nas montanhas de Itaipava em 2003 ao final da gestão do ministro Aldo Rebelo, em maio de 2015 -, podemos dizer, o adensamento da capacidade de Defesa nacional e a atualização conceitual do pensamento estratégico dão importantes saltos. Façamos a seguir uma breve apresentação de alguns dos logros no período. 
Em primeiro lugar, esta atualização estratégica pode ser sintetizada na frase do então ministro Celso Amorim para quem o Brasil possui uma estratégia de Defesa que prevê “cooperação para dentro, dissuasão para fora", ou seja, no nosso entorno geográfico deverá prevalecer uma postura de cooperação do Brasil para com os seus vizinhos.

Já no que diz respeito ao espaço exterior a nosso entorno estratégico, o Brasil deve manter capacidade de dissuasão, visando desencorajar eventuais tentativas de constrangimento à soberania nacional, sobretudo tendo em vista tendências de aumento das pressões direcionadas a países detentores de recursos naturais e ativos estratégicos, como é especialmente o caso do Brasil, tais como água potável, minérios, terras agricultáveis e capacidade de produção de alimentos, biodiversidade e energia - por exemplo, o Brasil poderá, em poucos anos, passar da $13^{\mathrm{a}}$ para a $4^{\mathrm{a}}$ posição em termos de produção de petróleo.

A Estratégia Nacional de Defesa, ao mesmo tempo, definia a reestruturação e reequipamento das Forças Armadas, visando robustecer nossa capacidade de Defesa. Para isso, propõe medidas visando desenvolver uma forte base tecnológica e industrial nacional de Defesa. Ambas as medidas tiveram importante curso no período em tela.

Assim, dá-se início de grandes projetos estratégicos das Forças Armadas.

Desde a Estratégia Nacional de Defesa, o Brasil começou a investir fortemente em grandes projetos estratégicos das Forças Armadas, acumulando potencial e capacidade para dar salto de qualidade na capacidade dissuasória brasileira, ao tempo que mobiliza base produtiva e tecnológica nacional.

Dentre outros projetos estratégicos iniciados, podemos citar:

- a construção do Submarino a propulsão nuclear, que representará expressivo avanço estratégico na capacidade de Defesa das águas territoriais brasileiras, num contexto em que suas riquezas, em especial o pré-sal, terá crescente importância na economia brasileira e na equação energética global. O primeiro Submarino convencional projetado e construído pelos brasileiros será entregue à Marinha entre 2018 e 2019. Com a obtenção daquele a propulsão nuclear, o Brasil, assim, será o primeiro país a ter esta capacidade além dos países do Conselho de Segurança da ONU - apenas a Índia igualmente está 
perto de alcançar esta capacidade. Por volta do bicentenário da independência, em 2022, teremos o Submarino a propulsão nuclear defendendo nossas águas.

- a assinatura do contrato para a aquisição e desenvolvimento conjunto, com os suecos, do novo avião de caça da Força Aérea Brasileira, o Gripen NG. Com isso, prepararemos condições para na próxima década desenvolvermos um caça nacional de $5^{a}$ geração. A exemplo do Submarino, também no caso do Caça, se buscará importante mobilização industrial para a nacionalização destes equipamentos.

- o desenvolvimento do projeto da Força Aérea Brasileira do grande avião militar cargueiro KC-390, pela Embraer, maior avião já produzido por esta empresa, que permitirá salto tecnológico na capacidade brasileira de construção de aviões. O primeiro protótipo do avião voou no final de 2014.

- programa de aquisição de helicópteros militares de grande porte (EC-725) denominado HX-BR, com potencial para que o Ministério da Defesa reúna capacitação para o Brasil projetar e construir um helicóptero nacional.

- desenvolvimento e construção do Satélite Geoestacionário de Defesa e Comunicações Estratégicas (SGDC), lançado neste 2017, que permitiu ao país reestabelecer completa autonomia nas comunicações militares.

- as primeiras entregas das mais de duas mil unidades do novo veículo blindado brasileiro Guarani, projetado pelo Exército Brasileiro. Neste caso, está posto o grande desafio de adensar seu índice de nacionalização, sobretudo em suas partes mais sensíveis.

- início da estruturação, na fronteira do Mato Grosso do Sul, do SISFRON (Sistema Integrado de Monitoramento de Fronteiras) - um grande sistema de monitoramento e presença em toda a fronteira terrestre brasileira -, que dará grande contribuição para impedir a chegada de drogas aos grandes centros urbanos brasileiros, numa importante contribuição da Defesa Nacional à segurança pública dos brasileiros. A segunda etapa do Sisfron já está em preparação e será desenvolvida no Paraná.

- desenvolvimento nacional, pela Avibras - uma empresa que é "joia da coroa" de nossa base industrial de Defesa -, do novo sistema lançador de foguetes Astros 2020, com mísseis de cruzeiro também nacional (TM300) com capacidade para atingir 300 quilômetros de alcance. Junto com a aquisição de modernas baterias antiaéreas russas 
Pantsir S-1 - com exigência de transferência de tecnologia à indústria nacional -, o Brasil dará importante salto na sua capacidade dissuasória antiaérea.

Ademais, dá-se expressivos passos iniciais na reorganização de uma Base Industrial e Tecnológica de Defesa

Na primeira gestão da presidente Dilma, sob a chefia de Celso Amorim, foi marcada pela formatação de um arcabouço legal e institucional visando apoiar a Indústria Nacional de Defesa. Se a Estratégia Nacional de Defesa foi ponto de inflexão na postura brasileira quanto a Defesa Nacional, a aprovação da Lei 12.598, em 2012, foi a materialização da orientação voltada ao objetivo de soerguer uma robusta base industrial de Defesa, a desenvolver e implementar. Nesta, definiu-se:

- normas especiais para as compras, as contratações e o desenvolvimento de produtos e sistemas de Defesa, priorizando a empresas brasileiras de capital nacional. Essa medida é especialmente importante no contexto do início de vários projetos estratégicos, como vimos acima.

- estabelecimento da figura da Empresa Estratégica de Defesa, definida pelo Ministério da Defesa, entre aquelas que desenvolvam produtos e processos tecnológicos e inovadores no país, que tenham sede no Brasil, e pelo menos 2/3 dos votos acionários nas mãos de brasileiros. Estas empresas terão um conjunto de medidas de apoio, desde a participação como prime contractor nos projetos estratégicos das Forças Armadas até concessão de financiamento específicos visando fortalecê-las. Atualmente já temos mais de 50 EEDs em variados segmentos da área de Defesa.

Importante destaque no primeiro governo de Dilma foi o Programa Inova Empresa, que previu a disponibilização de financiamento para empresas brasileiras investirem em inovação e tecnologia. O InovaAeroDefesa, focado em quatro áreas (Aeroespacial, Defesa, Segurança Pública e Materiais Especiais), aprovou 91 planos de 64 empresas líderes com potencial inicial de $\mathrm{R} \$ 8,68$ bilhões - quase 3 vezes mais que a oferta inicial, de $\mathrm{R}$ 2,9 bilhões disponíveis no edital.

A breve gestão de Aldo Rebelo à frente do Ministério da Defesa - de outubro de 2015 a maio de 2016 -, já em meio a crise que culminaria no impeachment de Dilma Rousseff teve que se defrontar com a atualização quadrienal dos documentos estratégicos de 
Defesa $^{98}$. Ademais, buscou enfrentar o problema do financiamento dos projetos estratégicos de Defesa, em meio a grave crise econômica que então já se apresentava99. Aldo Rebelo também daria importantes contribuição no que diz respeito ao marco conceitual do papel das Forças Armadas, ao apresentar o conceito de dupla missão das Forças, num país com as características do Brasil.

$* * *$

Leitura dos principais conceitos e ideias-força da Política e da Estratégia de Defesa vigentes $^{100}$

I -

A Política Nacional de Defesa (PND) é o principal documento de Estado que orienta uma visão mais próxima ao que poderíamos considerar preceitos de uma Grande Estratégia. Esta afirmação será ainda mais precisa, se considerarmos que seu escopo volta-se "contra ameaças preponderantemente externas, potenciais ou manifestas" (2.1.1). A legislação determina sua revisão quadrienal e envio ao Congresso Nacional para apreciação.

A PND busca "harmonizar as iniciativas de todas as expressões do Poder Nacional intervenientes com o tema, visando melhor aproveitar as potencialidade e as capacidades do país". Por certo, como vimos no primeiro capítulo desta Tese, o conceito de Poder Nacional, que na sua acepção de autores internacionais clássicos, quer na sua adaptação

${ }_{98} \mathrm{Na}$ condição de integrante do Ministério da Defesa, na condição de Chefe da Assessoria Especial de Planejamento (ASPLAN), unidade responsável, junto com o EMCFA (Estado Maior Conjunto das Forças Armadas) pela atualização dos três documentos estratégicos, contribuímos com sua revisão; contudo, a versão final foi encaminhada em 29/09/2017, quando já não mais estávamos no MD.

99 O Ministro Aldo defendeu e chegou a ter iniciativa legislativa apresentada no Congresso Nacional, propondo a instituição de Plano Plurianual, não contingenciavel, que garantisse estabilidade ao financiamento dos projetos estratégicos nacionais.

100 Para efeitos desta sessão do capítulo $\mathrm{V}$, utilizaremos as últimas versões dos documentos estratégicos de Defesa nacional, enviados ao final de 2016 para apreciação do Congresso Nacional. Como dito anteriormente, servindo ao Ministério da Defesa, no primeiro semestre de 2016, estivemos com responsabilidade executiva de preparação destes documentos; contudo, deixamos o governo antes da finalização da tarefa - tendo em vista o processo de deposição da então presidente da República. Assim, dado este debate ser objeto de nossa investigação cientifica, discutiremos aqui as principais teses dos documentos sob um prisma acadêmico. 
nacional, sistematizada sobretudo a partir da Escola Superior de Guerra, versa sobre um conjunto de temas duros constitutivos do projeto nacional em seu conjunto.

Por isso, pode-se dizer, que as últimas edições dos documentos de Defesa, enviadas ao Congresso Nacional nos últimos meses de 2016, preserva uma estrutura conceitual formulada há muito: sistematicamente, a partir da criação da Escola Superior de Guerra, mas com origens remotas que podem ser localizadas nas teses dos revolucionários de 1930 - como se vê na frase-epígrafe que abre este capitulo.

Assim, os documentos de Defesa versam sobre um escopo amplo: "consolidar seu Poder Nacional, compreendido como a capacidade que tem a Nação para alcançar e manter os Objetivos Nacionais, em conformidade com a vontade nacional. Manifesta-se em cinco expressões: a política, a econômica, a psicossocial, a militar e a científica e tecnológica".

Um desafio de tamanha magnitude exige que a Política de Defesa seja vista como um vértice do próprio projeto nacional brasileiro.

II -

A Política Nacional de Defesa, a despeito de caracterizar-se como documento de Estado, não é, e tampouco poderia ser, imune a conjuntura nacional.

Lê-se no texto que "O País, mesmo considerando a crise atual, experimentou nas últimas décadas uma melhora nos índices socioeconômicos, mas ainda insuficiente para ascendêlo à condição de plenamente desenvolvido".

Redigido em 2016, quando o país estava no terceiro ano de sua crise econômica e em meio a crise política que levou a destituição da própria Presidente da República, o documento por certo não poderia ignorar esta condicionante, com profundas implicações para o rumo e o curso do projeto brasileiro.

Sobretudo tendo em vista que a crise brasileira, que ao redigirmos esta Tese, não apenas persiste como não apresenta sinais claros de superação. "Somos um país que está à deriva, 
que não sabe o que pretende ser, o que quer ser e o que deve ser", disse o comandante do Exército, general Eduardo Dias da Costa Villas Bôas ${ }^{101}$.

Não foi, em absoluto, figura de retórica. O país, pelo menos desde a eclosão das manifestações de junho de 2013, perdeu a condição de normalidade e vive, desde então, situação de profunda conflagração nacional. Desde então, ao lado de produzir um resultado de queima de quase uma decima parte do PIB de uma das maiores economias do mundo, perdeu qualquer orientação estratégica de rumo e de sentido de projeto nacional.

Nesse contexto, podemos afirmar, ocorre uma perda liquida de Poder Nacional nas suas múltiplas acepções, seja nos elementos mais estáveis, seja, principalmente, naqueles variáveis.

A dimensão onde mais se expressa a perda de Poder Nacional é a econômica. Ao longo do período, aquelas entre as cadeias produtivas de maior dinamismo da economia nacional vem sendo atingida: Petróleo e Gás (P\&G), infraestrutura e construção civil, Industria de Defesa e naval, variados setores industrial, como o de maquinas e equipamentos e o de siderurgia, e mais recentemente, agronegócio, sobretudo na desestruturação da maior empresa de proteína animal do mundo, a JBS.

O setor da construção civil, ademais, tinha um papel de ponta de lança da própria projeção externa do país no mundo, numa espécie de braço empresarial de nossa política externa. Observe-se que o mapeamento e a divulgação da ilicitudes da Construtora Odebrecht no exterior foram divulgadas por relatório divulgado pelo Departamento de Justiça (DoJ, na sigla em inglês) do governo norte-americano, amealhado através de informações de inteligência.

101 Jornal Valor Econômico, 17/02/2017. 


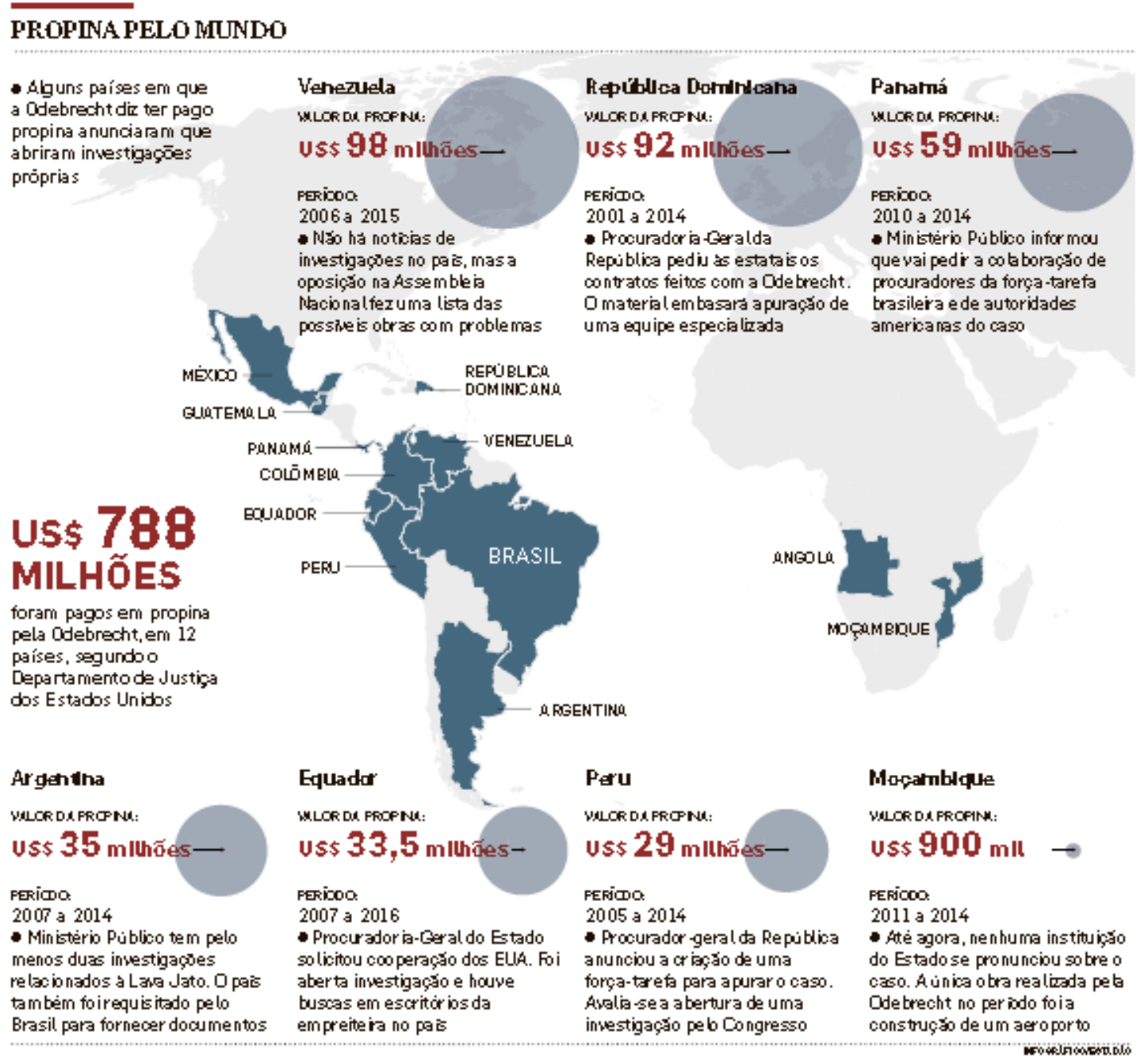

O Estado de S. Paulo, 10/01/17, p.A4

Curiosamente, os países mencionados no relatório do DoJ são exatamente aqueles dentre os países que o Brasil mais buscou ampliar sua influência nestas primeiras duas décadas do século XXI.

NO caso da JBS, a empresa tinha se tornado uma potência no abastecimento de proteína em varias partes do mundo, inclusive internamente nos Estados Unidos - portanto, num fator estratégico ligado a segurança alimentar destes países, como se vê no quadro abaixo. 


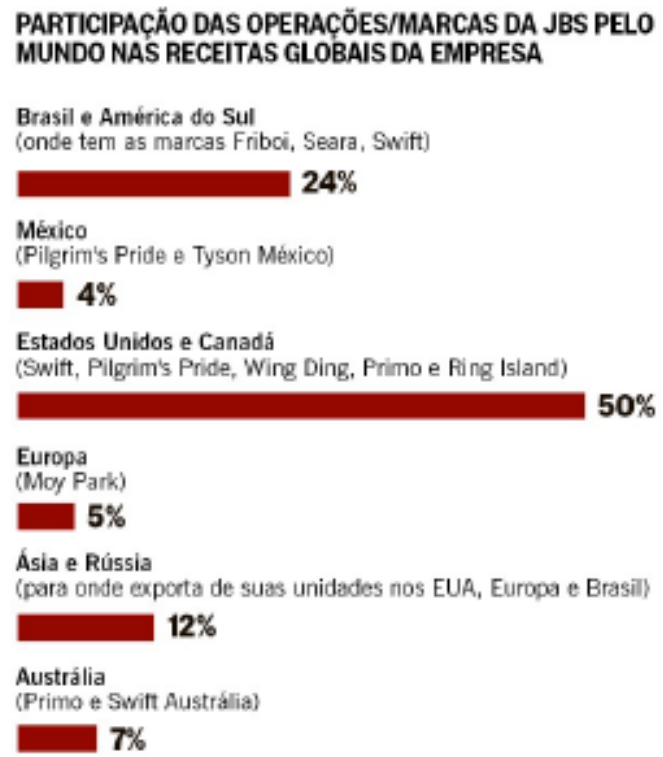

O Globo, 07/06/17, p.17

Ainda no plano do poder econômico, o país vai abrindo mão do exercício de política industrial e de instrumentos de financiamento do setor industrial, a partir de mudanças estruturais no BNDES (Banco Nacional de Desenvolvimento Econômico e Social).

Apontado como uma potência energética em variados estudos, o Brasil também definha neste outro elemento duro de Poder Nacional. A começar da Petrobras, que após a descobertas do pré-sal, iniciou um vultoso programa de investimentos e de inovação tecnológica visando concretizar o bilhete premiado para o desenvolvimento nacional. Contudo, fragilidades de governança na estatal permitiram prosperar esquema de corrupção, detectado inicialmente nas operações de inteligência denunciadas no episódio NSA/Snowden ${ }^{102}$. Hoje, a principal empresa brasileira encontra-se em franco processo de apequenamento, desfazendo-se de valiosos e estratégicos ativos e retirando-se de vários setores que constituem a cadeia produtiva de $\mathrm{P} \& \mathrm{G}$.

102 Sobre isto, ver relatório final da CPI da Espionagem do Senado Federal (disponível em https://www12.senado.leg.br/noticias/arquivos/2014/04/04/integra-do-relatorio-de-ferraco) - à qual este autor contribuiu oficialmente na qualidade de consultor externo -, e as diversas notícias da época. Por exemplo, recomenda-se "Brasil pode ser alvo de espionagem econômica, diz ex-agente da NSA", publicada no Portal Terra (https://www.terra.com.br/noticias/brasil/brasil-pode-ser-alvo-de-espionagem-economicadiz-ex-agente-da-nsa,2ac5af60428ff310VgnVCM10000098cceb0aRCRD.html). Na matéria, "Thomas Drake diz que a espionagem econômica é dos segredos mais profundos. Novas reservas de petróleo seriam o principal interesse no Brasil". Matéria do Programa Fantástico, da Rede Globo de Televisão, exibido em 08/09/2013, aborda especificamente a espionagem da NSA voltada a Petrobras, cuja rede interna de computadores seria monitorada. 
Também a Eletrobrás definha, às vésperas de sua anunciada privatização. Uma de suas subsidiarias, a Eletronuclear, tem, por exemplo, seu programa de construção da Usina Nuclear de Angra III, paralisado.

Observe-se que Petrobras e Eletrobrás são ícones do projeto brasileiro de desenvolvimento, criadas no segundo governo de Getúlio Vargas.

No aspecto objetivo, sobretudo ligado às esferas econômica, militar e científica e tecnológica do Poder Nacional poderíamos aqui traçar um quadro exaustivo sobre retrocessos no período mais recente. Contudo, os exemplo acima são eloquentes e corroboram o argumento inicial ${ }^{103}$.

No entanto, a crise brasileira impacta, como dissemos, não apenas sobre o vetores objetivos do Poder Nacional, mas também sobre os subjetivos. Refiro-me a perda de rumo e sentido do projeto nacional, com grandes implicações para o curso de nossa Grande Estratégia.

III -

Um terceiro aspecto nodal na Política de Defesa é a questão de sua contribuição para o desenvolvimento nacional. Como vimos acima, trata-se de tema clássico da geopolítica brasileira.

Esta relação é assim sintetizada na Estratégia Nacional de Defesa de 2008:

"Estratégia Nacional de Defesa é inseparável da estratégia nacional de desenvolvimento. Esta motiva aquela. Aquela fornece escudo para esta. Cada uma reforça as razões da outra. Em ambas, se desperta a nacionalidade e se constrói a Nação. Defendido, o Brasil terá como dizer não, quando tiver que dizer não. Terá capacidade para construir seu próprio modelo de desenvolvimento" (DEFESA, 2008, p.8)

103 Sobre um balanço do último ano desde a deposição da presidente Dilma, recém publicamos $\mathbf{A}$ desconstrução das bases do projeto nacional brasileiro, em obra coletiva, organizada por Renato Rabelo e Adalberto Monteiro, "Governos Lula e Dilma: O Ciclo Golpeado" (Fundação Mauricio Grabois I Editora Anita Garibaldi, 2017). 
É amplamente reconhecido na literatura a relação estreita entre Defesa e desenvolvimento $^{104}$. A experiência norte-americana quanto ao projeto nuclear e ao programa especial, num esquema de mobilização nacional científica e industrial, resultou em extraordinários transbordamentos inovativos para o conjunto de sua economia ${ }^{105}$. A decisão chinesa de iniciar, em 1978, um período de "reforma e abertura", foi fundamentado pela ideia das quatro modernizações, das quais uma delas era a da Defesa nacional ${ }^{106}$.

Assim, o estrito vínculo entre Estratégia de Defesa e Estratégia de Desenvolvimento, proposto na forma como vimos acima na primeira versão da END em 2008, está em linha com tendências históricas e atuais das principais economias mundiais e com a própria formulação estratégica brasileira. Como dissemos, pelo menos desde os anos 1950, o Brasil tem formulado sistematicamente sobre a relação de causa e efeito entre Segurança Nacional e Desenvolvimento.

São notórias as contribuições históricas das Forças Armadas ao desenvolvimento nacional. Primeiramente, no desafio da construção nacional, da integração do país. Já nos primórdios de nossa trajetória nacional, no início do século XVII, com os bravos Bandeirantes paulistas ou na figura do capitão Pedro Teixeira, a partir de Belém, na conquista definitiva da Amazônia, bases que possibilitaram a definitiva grandeza continental do território pátrio. Mais recentemente, ressalte-se o papel dos Batalhões de Engenharia de Construção ou com o papel heroico do Marechal Candido Rondon da integração de nosso território à Oeste.

\footnotetext{
${ }^{104}$ Recomendamos duas obras panorâmicas que apresentam o papel da pesquisa e da produção de armas e equipamentos para as Forças Armadas e sua relação com as transformações tecnológicas e com 0 desenvolvimento econômico:
}

- O voo da humanidade e as 101 tecnologias que mudaram a face da terra, do General José Carlos Amarante (Biblioteca do Exército Editora, 2009), e;

- Dos raios X à bomba atômica (1895 - 1945): os 50 anos que mudaram o mundo, de Roberto Cesareo (Embrapa informação tecnológica, 2010).

105 Sobre a experiência norte-americana de Inovação em Defesa, ver Ciência e Tecnologia de impacto: uma análise do caso DARPA, de Flavia Schmidt e Fernanda de Negri (in RAUEN, 2017).

106 Ver "Military Modernization in Chinese Technical Progress and Industrial Innovation", de Nicholas Trebat e Carlos Aguiar de Medeiros in Review of Political Economy, 2013. 
As contribuições das Forças Armadas ao grande desafio de industrialização nacional também são notórias. Podemos ver exemplo já no século XIX, seja com a estruturação do arsenal da Casa do Trem, em 1808, no Rio, seja na Siderurgia, com a Fábrica de São João do Ipanema, próxima a Sorocaba, surgida em 1818 sob direção do Exército. No século $\mathrm{XX}$, com o arranjo que permitiu, a construção da Companhia Siderúrgica Nacional em Volta Redonda, no contexto da participação do Brasil na $2^{a}$ Grande Guerra. Observe-se ainda esta contribuição no primeiro auge de nossa Indústria de Defesa nos anos 1970 e 1980, a partir de empresas como a AVIBRAS, a ENGESA e a EMBRAER.

Desde a diretriz da END de 2008, o Brasil vem avançando na tarefa definida de "reorganizar a Base Industrial de Defesa”. Em especial no arcabouço jurídico, instituímos legislação que valoriza as Empresas Estratégicas de Defesa majoritariamente de capital nacional, ainda que pouco se tenha avançado no apoio a sua sustentabilidade econômica.

Esta diretriz deveria seguir sendo eixo estruturante da política e da estratégia nacional de Defesa, visto, todavia, não ter sido efetivada integralmente - demos apenas os primeiros passos neste sentido. Contudo, seja no plano conceitual, seja na sua estruturação efetiva, observamos retrocessos que precisarão serem enfrentado.

No plano conceitual as atuais versões da PND e da END apresentam uma relativa diluição da centralidade do binômio defesa e desenvolvimento, ao introduzir um terceira questão: a diplomacia. Assim, diz a PND, "esses três pilares - Desenvolvimento, Diplomacia e Defesa - devem ser explorados com maior ou menor profundidade conforme o caso concreto, a fim de garantir a Segurança e a Defesa nacionais" (3.1). Que a diplomacia de Defesa é um instrumento da ação estratégica não há dúvidas; aliás, o engajamento bélico propriamente é uma das etapas de um contencioso interestatal. Contudo, aqui se trata, no plano da política (PND), ser documento orientador de mais alto nível, ao qual, deveria ter sido mantido a proposição clássica e anterior quanto ao binômio central: defesa e desenvolvimento.

Observam-se retrocessos também quanto a própria diretriz de fortalecimento da Base Industrial de Defesa.

Com a crise, há importante diminuição nos gastos em Defesa.

Comparando os gastos de 2016 com 2014 - último ano relativamente normal do governo Dilma -, observa-se que o gasto ao final de ano passado, foi $R \$ 3,1$ bilhões a menos. 
Aliás, o próprio ministro da Defesa, Raul Jungmann, ao comentar em reportagem do jornal Folha de São Paulo a questão, propôs "voltar ao pico do começo da década de 2010”, ou seja, entre o final de Lula e início de Dilma ${ }^{107}$.

A diminuição dos investimentos em projetos estratégicos das Forças Armadas poderá ser no próximo período, se não se reverter a inflexão atual, num fator de fragilização do braço armado do Poder nacional.

O impacto do teto de gasto no orçamento federal, promulgado este ano pelo presidente Michel Temer, para os investimentos em projetos estratégicos nacionais poderá ser dramático em pouco tempo. O próprio governo, em relatório entregue ao Valor Econômico (01/03/17), aponta para uma queda, e em alguns caso até de desaparecimento, da rubrica investimentos, no âmbito das despesas discricionárias (não-obrigatórias) da União, mesmo no improvável cenário de aprovada a reforma da previdência na forma proposta pelo Executivo.

O jornal fala de cinco projetos que estariam sendo priorizados: programa de submarinos da Marinha, na FAB caças Gripen e avião cargueiro KC-390, produzidos pela Embraer, e no Exército, blindado Guarani e vigilância das fronteiras terrestres (Sisfron).

Ocorre que todos estes projetos, longos contratos de aquisição e desenvolvimento, tem desembolsos igualmente alongados. Em todos os cinco citados, aliás, os desembolsos já realizados são inferiores ao ainda a pagar, como mostra a tabela abaixo, tornada pública pelo Ministério da Defesa em audiências na Câmara dos Deputados e no Senado Federal, em novembro último.

107 Ver matéria em http://www1.folha.uol.com.br/poder/2017/03/1865893-em-meio-a-crise-governo-temer-

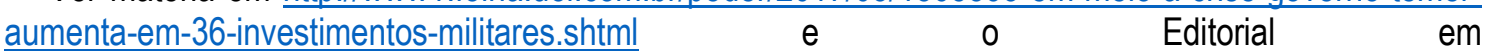
http://www1.folha.uol.com.br/opiniao/2017/03/1866211-prioridades-militares.shtml 


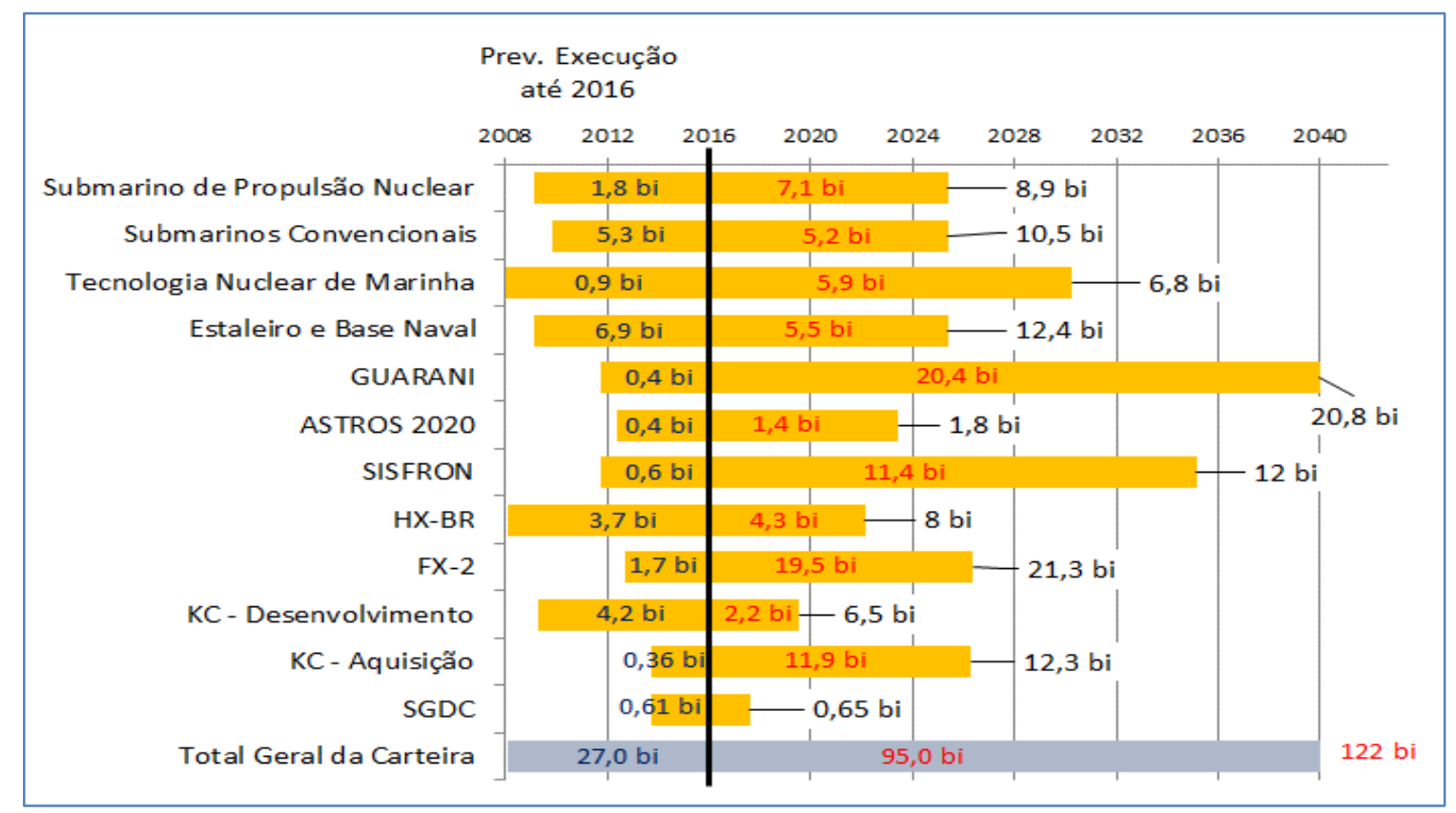

Isso torna necessário um debate sobre as formas do país garantir a continuidade dos projetos estratégicos nacionais num quadro em que estes entram em contradição com a política econômica do governo atual.

Cabe resgatar que nos governo Lula e Dilma ocorre uma importante elevação dos investimentos para aquisições de Defesa, com o início efetivo de grandes projetos estratégicos das Forças Armadas. Estes investimentos são consequências da Política (PND) de 2005 e da Estratégia Nacional de Defesa de 2008, orientações de Estado, a partir das quais o país realiza uma inflexão importante, iniciando estes grandes projetos, a partir da ideia-força de equiparar a estatura de Defesa à estatura geopolítica do Brasil, então em franca ascensão.

Já no período final de Dilma, com Aldo Rebelo, como dissemos, o Ministério da Defesa inicia estudos no sentido de elevar os gastos em Defesa para $2 \%$ do PIB, um salto factível, ainda que, na média, inferior a China, Índia ou Rússia, países dos BRICS. Esse incremento poderia finalmente tornar factível o PAED (Plano de Articulação e Equipamento de Defesa), amplo conjunto de projetos de modernização das Forças Armadas que começou a ser desenhado em 2012, com o Livro Branco de Defesa Nacional. 
A Defesa nacional, no governo Temer, sofre consequências de políticas e iniciativas que vão contra o interesse nacional e fragilizam o projeto nacional. As graves restrições de financiamento do sistema de ciência, tecnologia e inovação demonstram isto. A fragilidade e a ameaça de desnacionalização de "joias da coroa" de nossa base industrial de Defesa - empresas de tecnologia avançada de capital nacional -, igualmente.

A Marinha do Brasil, por exemplo, anuncia a desativação do Navio Aeródromo ("portaaviões") São Paulo ${ }^{108}$. Com isso, provavelmente por alguns anos, o Brasil deixará de ser o único país do hemisfério sul - e um dos seis do mundo - a possuir este instrumento chave numa Esquadra para a projeção de poder.

A reversão desta deterioração do processo de reequipamento das Forças Armadas e de fortalecimento da base Industrial de Defesa é determinante para o projeto nacional brasileiro. Afinal, como dissemos acima, é dado amplamente reconhecido na literatura que trata de desenvolvimento econômico e inovação tecnológica, do papel chave da Indústria de Defesa naqueles países que atingiram a condição de economias com alto grau de desenvolvimento. Para citar exemplo mais recente, poderíamos citar a decomposição das tecnologias que deram origem aos mais modernos telefones celulares, todas de origem militar, financiadas a fundo perdido pelo Estado ${ }^{109}$.

No próximo período, está posto o desafio de avançar novos passos na reorganização da BID e de avançar no fortalecimento da capacidade material das Forças Armadas. Para isto, o Brasil precisará:

- Estruturar um robusto Sistema de Inovação em Defesa Nacional, base para engate de nossa base Industrial à economia do conhecimento deste século XXI. Estudar um Fundo e uma Agencia especifica para Inovação em Defesa, nos moldes dos recursos de "subvenção econômica" existentes no âmbito do FNDCT e com base na experiência de agencias como a FINEP. Promover uma maior integração entre as ICTs civis e militares, a Indústria e as agências de fomento à Inovação e ao desenvolvimento econômico e industrial;

108 ver http://politica.estadao.com.br/noticias/geral,marinha-decide-desativar-unico-porta-avioes-decombate-do-pais, 70001665945

109 Ver MAZZUCATTO, Mariana. O Estado Empreendedor - desmascarando o mito do setor público vs. Setor privado / tradução Elvira Serapicos. - $1^{\text {a }}$ ed. - São Paulo: Portfolio Penguin, 2014. 
- Perseguir o desafio de obter autonomia produtiva e tecnológica em áreas críticas e sensíveis para a Defesa nacional. O Ministério da Defesa, em conjunto com as Forças singulares, deve trabalhar na estruturação de um sistema de inteligência tecnológica e de prospecção de tendências da guerra moderna visando definir programas mobilizadores voltados a reunir a ciência e a Indústria, bem como os órgãos de fomento, na superação de gargalos críticos ou sensíveis para a Defesa Nacional.

- Com base nestas definições - áreas em que decidirmos buscar autonomia produtiva e tecnológica - o Estado brasileiro deverá avançar na estruturação de conglomerados de empresas (clusters) por segmento de Defesa, a partir de empresas pivôs apoiados em redes de pequenas e medias empresas.

- Equacionar o problema do financiamento do sistema de Defesa Nacional. Sendo instituições permanentes da nacionalidade, as Forças Armadas e a estrutura da qual provem sua base material - a Base Industrial de Defesa - devem ter um sistema de financiamento não sujeito a descontinuidades ou a oscilações conjunturais. Propusemos ao Congresso Nacional, neste sentido, que buscássemos estabilizar os recursos à Defesa Nacional na casa de $2 \%$ do PIB, cifra próxima aos gastos médios de países com dimensões geográficas e econômicas próximas a do Brasil (BRICS). Devemos, no próximo período, estudar como os principais países financiam seus sistemas de Defesa, visando dialogar com o Congresso Nacional para propor uma sistemática adequada a realidade brasileira.

- Relacionados aos itens anteriores, efetivar um planejamento com horizonte de 20 anos, revisto quadrienalmente, visando o equipamento material das Forças Armadas, nos termos em que foi previsto com o PAED (Plano de Articulação e Equipamento em Defesa). Nos últimos anos avançamos no reequipamento das Forças singulares; para referir-se ao mais destacado, observemos o programa de obtenção do Submarino a propulsão nuclear; dos caças GRIPEN NG e do avião cargueiro KC390; ou ainda do blindado Guarani e ASTROS 2020, como seu míssil de 300 quilômetros, todos elementos chave na estratégia de dissuasão. O desafio será dar cabo a um programa articulado em seu conjunto, concatenado a tendências da guerra moderna e aos desafios de reindustrialização baseado em Inovação, na qual o setor de Defesa cumpre papel chave, como se vê na trajetória de outros países desenvolvidos. 
- Por fim, o uso do Poder de Compra das Forças Armadas e do Ministério da Defesa será chave na contribuição ao desenvolvimento tecnológico e industrial do país. Aprimorar o seu uso será essencial no próximo período.

Retornando ao texto da PND, cabe observar algumas limitações que são reconhecidas pelo documento e que dialogam com as necessidades que buscamos apontar acima. Diz o texto que

“[...] a falta de regularidade nas aquisições de Produtos de Defesa - PRODE e da alocação de recursos orçamentários tem desestimulado os investimentos por parte da Base Industrial de Defesa - BID. As demandas das Forças Armadas e a defasagem tecnológica provavelmente manterão inalterados os níveis de produção da BID dos últimos anos. Nesse sentido, o ritmo do desenvolvimento tecnológico brasileiro, considerando os atuais níveis de investimento, não permite vislumbrar a eliminação da dependência externa em áreas de fundamental importância para a indústria, nos próximos vinte anos” (2.2.5)

Aqui aparecem duas afirmações graves: que "a defasagem tecnológica provavelmente manterão inalterados os níveis de produção da BID dos últimos anos" e que "não permite vislumbrar a eliminação da dependência externa em áreas de fundamental importância para a indústria, nos próximos vinte anos".

Tendo em vista o desenvolvimento nacional por meio da agregação de Poder Nacional, não será possível raciocinar nesta chave. Ao contraio, essa tendência - que efetivamente se apresenta hoje no quadro da transitoriedade da presidência de Temer - não deve ser aceita pelo pensamento estratégico nacional. As medidas acima listas tem potencial de reverter esta realidade e efetivamente contribuir para que a Defesa nacional exerça papel de polaridade do desenvolvimento nacional de alta intensidade inovativa e tecnológica.

IV -

Tendo em vista o escopo da PND - voltada "contra ameaças preponderantemente externas, potenciais ou manifestas" -, a leitura sobre o quadro internacional é aspecto de grande relevância ${ }^{110}$.

110 Tendo em vista discorrermos longamente sobre o quadro internacional no capitulo III, abordaremos que esta questão aqui, no que diz respeito ao texto da PND/END, apenas de forma ligeira. 
O Brasil é um país pacifico, diz o texto. Contudo, o cenário internacional caracteriza-se por um "condição sistêmica de instabilidade" e "emergência de novas ameaças".

O pacifismo brasileiro decorre, antes que nada, da própria natureza de seu território, extenso e todavia não integrado. Esse fator estável do Poder Nacional, o território, permite ao Brasil contrariar o determinismo expansionista de Ratzel e tornar-se um país territorialmente satisfeito mesmo num contexto de ascensão nacional ${ }^{111}$.

De fato, como vimos no capitulo terceiro, a situação de instabilidade no sistema internacional é marca da situação internacional. Ao mesmo tempo, a questão das chamadas "novas ameaças" precisaria ser melhor decomposta. Não se trata, a nosso ver, de aderir tardiamente à tese das "novas ameaças" na forma propagada pelos think-thanks dos países centrais anglo-saxões, no imediato pós-guerra fria. Aquela, tratava essencialmente de desviar doutrinariamente as Forças Armadas de sua função precípua a defesa da soberania - e engajá-las em funções de outra natureza, com a policial (contra o narcotráfico) ou a deterioração ambiental.

Por "novas ameaças", na conjuntura presente do mundo, devemos compreender um conjunto de fenômenos novos - ou talvez não tão novos assim -, ligados aos problemas migratórios, do terrorismo, da massificação das redes sociais, etc. combinados com a evolução tecnológica e as novas formas de sua utilização estratégica.

111 Segundo a síntese de Pezerat Correia (2010, p.134), as Sete leis de expansão dos Estados (1901) de Ratzel, base do conceito de espaço vital são:

1 - A extensão dos Estados aumenta com o avanço de sua cultura.

2 - 0 crescimento espacial dos Estados acompanha outras manifestações de seu desenvolvimento: a ideologia, a produção, a atividade comercial, o poder de sua imagem, do seu esforço de proselitismo.

3 - Os Estados estendem-se assimilando ou absorvendo as unidades políticas de menor importância;

4 - A fronteira é um órgão situado na periferia do Estado (considerado como um organismo); pela sua localização materializa o crescimento, a força e as mudanças territoriais do Estado;

5 - Procedendo a sua extensão espacial, o Estado esforça-se por absorver as regiões importantes para 0 seu designo: o litoral, as bacias fluviais, as planícies e, principalmente, os territórios mais ricos;

6 - É do exterior que vem o primeiro impulso levando o Estado à extensão do seu território, atraído por uma civilização inferior a sua;

7 - A tendência geral para a assimilação ou absorção - das nações mais fracas - convida a multiplicar as apropriações de territórios num movimento de certa maneira auto-alimentada. 
Trata-se de algo mais próximo ao que a PND compreendeu ser "cenário propício para o desenvolvimento da denominada "guerra híbrida"” (2.3.2). Por guerra hibrida, entendese,

"[...] um conceito cada vez mais adotado para a definição de novos conflitos do século XXI, frequentemente chamados de "conflitos do futuro", em que ações de combate convencional são aglutinadas, no tempo e no espaço, com operações de natureza irregular, de guerra cibernética e de operações de informação, dentre outras, com atores estatais e não-estatais, no ambiente real e informacional, incluindo as redes sociais. Sua natureza realça características dos conflitos contemporâneos e tornam a definição das missões das Forças Armadas muito mais complexa, dinâmica e sofisticada".

Posto neste diapasão, compreende-se com maior propriedade a definição de "novas ameaças". Inclusive, a partir da difusão deste conceito, caberia desenvolver uma investigação especifica, futuramente - guardando maior distância do fato histórico e aguardando o aparecimento de informações e fontes primarias desclassificadas -, quanto a possível utilização de mecanismos de guerra hibrida contra o Brasil, na grande crise que o país vive desde 2013.

A PND traz outra afirmação que cabe examinar:

"Em decorrência da globalização, os Estados têm-se desenvolvido e se tornado mais interdependentes, e associações político-econômicas de países se formam ou se fortalecem em busca de maior influência internacional. Os benefícios desse processo, contudo, não se distribuem equitativamente, deixando à margem países e regiões, o que resulta na elevação da taxa de desemprego e na volatilidade financeira, dentre outros efeitos adversos" (2.3.1).

Aqui seria necessário qualificar - sem repetir os argumentos do capitulo III - o fenômeno da crise da globalização, que rebaixa laços de interdependência ao tempo que seus malefícios (e não seus benefícios) se manifestam em sua inteireza, gerando um conjunto de fenômenos novos com implicações securitárias.

Noutro trecho, a PND faz uma importante distinção entre um crença idealista sobre "valores, instituições e normas internacionais" e a realidade, marcada pela relação de força entre os Estados. Vejamos:

"No campo diplomático, o Brasil, por sua tradição, valoriza e promove a convivência harmônica entre os países e defende um mundo cuja governança se baseie em valores, instituições e normas internacionais. A história, contudo, demonstra que as relações de força desempenham papel relevante na interação estatal, de forma que "nenhum Estado pode ser pacífico sem ser forte", conforme defendido por José Maria da Silva Paranhos Júnior, Barão do Rio Branco, patrono da diplomacia brasileira" (2.2.7). 
Como dito anteriormente neste capítulo, o surgimento do conceito de entorno estratégico na PDN (Política de Defesa Nacional) de 2005 representou importante ineditismos no pensamento estratégico brasileiro, por demonstrou regiões onde preferencialmente o país que irradiar influencia, nas citadas palavras de Fiori.

A definição na PND (2016) é a que segue:

“[...] sem desconsiderar a esfera global, estabelece como área de interesse prioritário o entorno estratégico brasileiro, que inclui a América do Sul, o Atlântico Sul, os países da costa ocidental africana e a Antártica. [...] Além disso, em função das tradicionais relações, a América do Norte e a Europa também constituem áreas de interesse e, ainda, em face dos laços históricos e afinidades culturais com o Brasil, os países de língua portuguesa merecem especial atenção aos esforços de cooperação no campo da Defesa. Igualmente, ao norte, a proximidade do mar do Caribe impõe que se dê crescente atenção àquela região" (2.1.6 e 2.1.7)

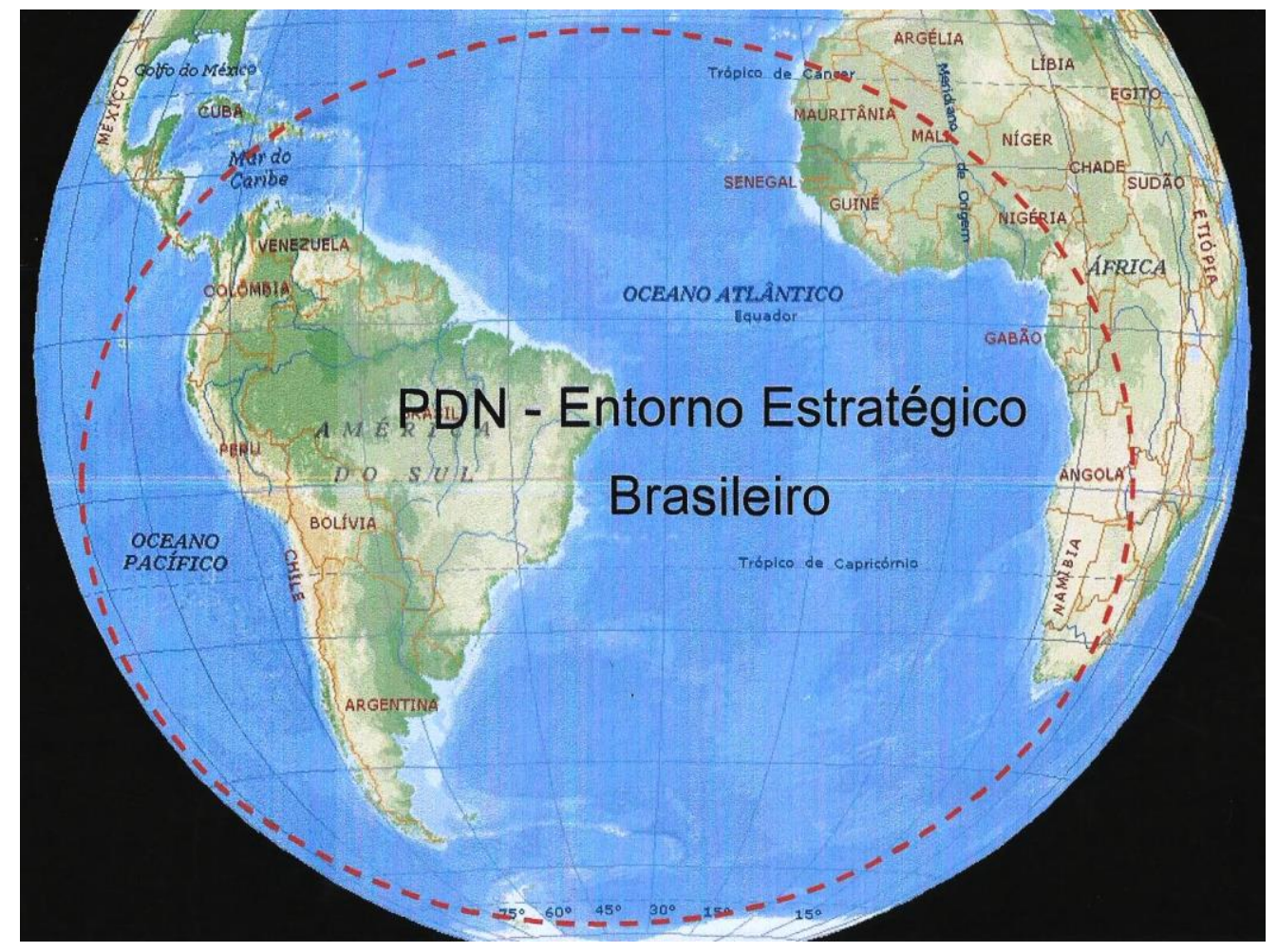

A inclusão de América do Norte e Europa como "área de interesse" é a novidade que aparece na edição de 2016 em relação às políticas de Defesa de 2012 e de 2005. Não creio que o texto da Política queira sugerir ser América do Norte e Europa como entorno estratégico, mas como “área de interesse”. Ocorre que o deslocamento do eixo dinâmico 
da economia e da geoestratégia global do Atlântico Norte para o Pacífico - mais especificamente à extensa região cujo centro é a China, faz com que a área de interesse não se restrinja ao velho mundo. Talvez aqui transpareça um cacoete não explicitado pelo redator final do documento.

Da mesma forma que o deslocamento do Caribe de "entorno estratégico" (PND-2012) para área de interesse (PND-2016) é absolutamente despropositado e talvez só tenha sido feito por visão ideológica. Afinal, do ponto de vista geoestratégico, é conhecida a tese de Nicholas Spykman em Estados Unidos frente al mundo (1944), segundo quem a fronteira sul do "mediterrâneo americano" - o mar do Caribe - encontra-se precisamente no norte amazônico da América do Sul. Esta visão de Spykman, como se sabe, até os dias atuais constituem um dos pilares da Grande Estratégia norte-americana. A propósito, é o mesmo Spykman que denomina o capítulo VII da obra citada como "As duas Américas”, diferenciando a anglo-saxã da latina.

O entorno de segurança brasileiro, pode ser dizer, é formado por dois subcomplexos geográficos estruturado numa situação de dicotomia: O Pacífico Norte-andino, que se estende até as Guianas versus o Atlântico/Cone Sul.

Trata-se de áreas geográficas de interesse mais imediato do Brasil que se complementam a leitura geopolítica do próprio território nacional - subcomplexos endógenos -, como vimos na contribuição do General Golbery. Nesse contexto, urge um olhar e uma estratégia própria para o Caribe.

Desnecessário será repetir aqui - já abordamos o tema anteriormente nesta Tese -, quanto aos enormes prejuízos que a recente crise brasileira trouxe à sua presença na área que reconhece como entorno estratégico. Recorde-se que o Brasil observou um cenário absolutamente favorável a sua expansão em seu entorno durante os primeiros quinze anos do século XXI, sobretudo, tendo em vista os Estados Unidos, desde os episódios de 11 de setembro de 2001, ocuparem-se, efetivamente, de outra agenda que não a hemisférica. Em termos securitários, a falência do pan-americanismo hemisférico baseado no velho TIAR (Tratado Interamericano de Assistência Reciproca) do pós-guerra - desmoralizado na guerra das Malvinas - deu lugar a um cooperação promissora a partir do Conselho de Defesa Sul-americano constituído no âmbito da Unasul (União das Nações Sul- 
americanas). Foi o período, no conceito introduzido pelo ministro Celso Amorim, de "dissuasão para fora, cooperação para dentro"112.

Após a deposição de Dilma Rousseff, a orientação do novo governo é outra. Em especial, a hostilidade aos bolivarianos congelou a cooperação estratégica em nível sul-americano, abrindo espaço para que outras potências extra regionais - especialmente a China e a Rússia - se introduzam no subcontinente de interesse mais imediato do Brasil. Como se diz coloquialmente, um verdadeiro tiro no pé.

$\mathrm{VI}-$

Passemos a examinar agora as definições da Política e da Estratégia de Defesa quanto às áreas geográficas endógenas prioritária de Defesa nacional. Para tanto, busquemos examinar as definições propostas na PND a respeito:

\footnotetext{
"Do ponto de vista da Defesa, sem descuidar-se das demais regiões brasileiras, deve-se ter maior atenção às áreas onde se concentram os poderes político e econômico e a maior parte da população brasileira, além da Amazônia e do Atlântico Sul” (2.2.12).

"A enorme extensão territorial, a baixa densidade demográfica da Amazônia brasileira e as dificuldades de mobilidade, bem como seus recursos minerais, seu potencial hidroenergético e a valiosa biodiversidade que abriga, exigem a efetiva presença do Estado, com vistas ao desenvolvimento e à integração daquela região" (2.2.13).

"Por sua vez, a natural vocação marítima brasileira é respaldada pelo seu extenso litoral, pela magnitude do comércio exterior através dele praticado e pela incontestável importância estratégica do Atlântico Sul, o qual acolhe a denominada "Amazônia Azul", ecossistema de área comparável à Amazônia brasileira e de vital relevância para o País, na medida em que incorpora elevado potencial de recursos vivos e não vivos, entre estes, as maiores reservas de petróleo e gás do Brasil” (2.2.15).
}

A proteção estratégica do núcleo político e econômico do país - formado, em seu núcleo mais restrito, por um triangulo cujas vértices ligam Brasília - Rio de Janeiro - São Paulo - Brasília justifica-se plenamente tendo em vista ser área geográfica onde se concentra a direção do país e suas fontes de riqueza industrial, cientifica e tecnológica, ademais da maior parte da população.

112 Ver AMORIM, Celso. A Grande Estratégia do Brasil. Funag/Editora Unesp, Brasília/São Paulo, 2016. 
A questão "nova" e mais fundamental aqui é a percepção quanto a Amazônia e ao Atlântico Sul. Por longo período, o Brasil concentrou sua preocupação estratégica no Rio da Prata. Desde a colônia, passando pelo período do Império e pela maior parte do século $\mathrm{XX}$, percebia-se que ameaças a integridade territorial e a soberania nacional partiriam dos países vizinhos ao sul do subcontinente.

De fato, o único conflito bélico a atingir o território brasileiro ao longo da história independente do país foi a Guerra do Paraguai, deflagrada por iniciativa de Assunção. Posteriormente, a rivalidade com Buenos Aires pela supremacia da América do Sul justificava que as hipóteses de guerra (HG) do Conceito Estratégico Nacional concentrassem, nas fronteiras sul, parte substancial das guarnições militares. Não por acaso, o Estado do Rio Grande do Sul, até hoje, sedia parte substantiva das guarnições de cavalaria e infantaria.

Quanto ao Atlântico Sul, como vimos, condicionados pela geopolítica da guerra fria, a Marinha do Brasil entre o pós guerra e meados dos anos 1970, concentrava-se em possuir capacitações voltadas à guerra antissubmarino, pois previa-se que uma ameaça comunista, isto é, da União Soviética contra o hemisfério americano poderia deflagrar-se com fechamento de rotas marítimas por submarinos soviéticos - como aliás, os alemães já haviam feito, defronte o litoral brasileiro, na primeira e na segunda guerra mundial.

O fim da guerra fria, a início da unipolaridade norte-americana e a percepção quanto aos riscos que a nova ordem mundial derivava para a soberania e a integridade nacional provocarão, paulatinamente, um movimento de atualização da percepção geoestratégica brasileira. Ele implica em reposicionamento da própria disposição da concentração de forças no território nacional. Como diz a END de 2008,

\footnotetext{
"As principais unidades do Exército estacionam no Sudeste e no Sul do Brasil. A esquadra da Marinha concentra-se na cidade do Rio de Janeiro. As instalações tecnológicas da Forças Aérea estão quase todas localizadas em São José dos Campos, em São Paulo. As preocupações mais agudas de defesa, porém, no Norte, no Oeste e no Atlântico Sul" (DEFESA, 2008, p.13).
}

A Amazônia é a base sob a qual se assenta aparte mais substancia da potencialidade nacional. Assim, o desafio amazônico permanece como uma grande questão nacional a equacionar neste século, se quisermos efetivamente alavancar o desenvolvimento 
nacional. Sendo $60 \%$ do território nacional e $5 \%$ da superfície do globo terrestre, possuindo $20 \%$ de toda a água doce e $30 \%$ das florestas tropicais ainda preservadas no planeta, a Amazônia guarda imenso potencial - todavia não plenamente aproveitado para ser um dos vetores centrais do projeto nacional de desenvolvimento.

Nos últimos anos, transformações importantes se registraram na Amazônia: as obras das três maiores usinas hidrelétricas em construção no mundo (as duas Usinas do Rio Madeira e Belo Monte); a integração de todos Estados da região ao sistema elétrico nacional; a reorganização, em 2007, da Superintendência do Desenvolvimento da Amazônia (SUDAM), extinta no governo de Fernando Henrique; a efetiva entrada em vigor do Fundo de Desenvolvimento da Amazônia (FDA), regulamentado recentemente (segundo governo de Dilma); e o início do aproveitamento das grandes

reservas de gás no Estado do Amazonas - que já abastece Zona Franca de Manaus. Agregue-se a prorrogação da vigência da Zona Franca de Manaus por 50 anos, até 2073, em agosto de 2014.

Entretanto, muitos desafios permanecem. Para vencê-los, será necessário superar ação de potências estrangeiras e seus aliados internos que atuam fortemente - por meios diretos e indiretos, inclusive ideológicos - numa "geopolítica da contenção", que busca bloquear o uso pleno e sustentável pelos brasileiros das vastas riquezas amazônicas, impondo-nos uma autolimitação. Nessa questão, avulta a manipulação da questão indígena e a ideologia "preservacionista".

Devemos pôr em marcha uma estratégia nacional, coordenada a partir da própria Presidência da República, para a exploração plena e sustentável das vastas riquezas da Amazônia, em especial seus recursos minerais, aquíferos, energéticos e sua biodiversidade. Especialmente ganha relevo por em marcha uma economia da biodiversidade - intensiva em C\&T -, explorando o revolucionário potencial da biotecnologia. Devemos efetivar nova política industrial com recorte para a Amazônia, visando produzir commodities com intensa agregação local de valor e conhecimento.

Grande desafio será o desenvolvimento da infraestrutura logística na Amazônia, integrando-a plenamente ao território nacional. Obras como a BR-163 (Cuiabá Santarém) e a BR-319 (Porto Velho - Manaus), bem como da Ferrovia Transcontinental 
ligando Cruzeiro do Sul (AC) ao litoral do RJ são essenciais nesse novo esforço para completar a integração nacional. O país deveria, no próximo período, atualizar o "Plano Amazônia Sustentável", a partir de uma grande conferencia nacional, que considere, ademais de aspectos ambientais, os geopolíticos e estratégicos, políticos, sociais e econômicos.

Por fim, o Brasil deverá propor o relançamento da OTCA - Organização do Tratado de Cooperação Amazônica, tornando-a uma organização politicamente forte e dotada de meios para integrar a região a partir do vetor geográfico Amazônia, visando inclusive restringir a presença de potencias extrarregionais em nosso entorno.

No plano estratégico já está em marcha importante movimento de deslocamento de tropas terrestres para a Amazônia. O movimento é substancial. Segundo informações do Comandante do Exército, General Villas Bôas, passamos de 6 mil para 30 mil homens na Amazônia, de um total de 225 mil homens do Exército ${ }^{113}$.

Recentemente a Marinha do Brasil tem avançado noutra questão chave: a proteção da Foz do Rio Amazonas. Desde a versão de 2008, está em pauta a constituição da Segunda Esquadra da Marinha, que "iniciará os estudos e preparativos para estabelecer, em lugar próprio, o mais próximo possível da foz do rio Amazonas, uma base naval de uso múltiplo, comparável, na abrangência e na densidade de seus meios, à Base Naval do Rio de Janeiro" (DEFESA, 2008, p. 23).

Em julho último, o Almirante de Esquadra Sergio Roberto Fernandes dos Santos, comandante de Operações Navais da Marinha do Brasil, esteve em São Luís para conversação com o governador do Maranhão, Flávio Dino no Palácio dos Leões sobre a instalação da Segunda Esquadra da Marinha no Estado ${ }^{114}$.

\footnotetext{
113 Informação prestada em depoimento na Comissão de Relações Exteriores e Defesa Nacional do Senado Federal, em 22/06/2017.

114 Ver "Governador e comandante de Operações Navais da Marinha falam sobre implantação da Segunda Esquadra" em http://www.ma.gov.br/governador-e-comandante-de-operacoes-navais-da-marinha-falamsobre-implantacao-da-segunda-esquadral (acessado em 28/09/2017).
} 
A Segunda Esquadra cobrirá toda a área geográfica litorânea norte do Brasil, com foco na área geográfica que vai de São Luís (MA) ao Oiapoque (AP).

A segunda questão a considerar aqui é a priorização da outra Amazônia, a Amazônia Azul, isto é, o conjunto do Atlântico Sul que defronta a costa brasileira. Trata-se de uma área soberana que corresponde a 52\% do território seco do Brasil, ou seja, 4,5 milhões de metros quadrados, sendo 3,6 milhões de $\mathrm{km} 2$ correspondente a nossa Zona Econômica Exclusiva, acrescida de 900 mil km2 de Plataforma Continental, além das 200 milhas náuticas. Destas aguas jurisdicionais provem $85 \%$ do petróleo e $75 \%$ do gás natural, além de se $95 \%$ do comercio exterior.

No estudo das potencialidades da Amazônia Azul, a Marinha propõe um enfoque a partir de quatro vertentes: Cientifica, Ambiental, Econômica e de Soberania ${ }^{115}$

Do ponto de vista cientifico, o Brasil possui a Comissão Interministerial para os Recursos do Mar (CIRM), presidida pelo Comandante da Marinha, e que leva a cabo importantes projetos ligados à Amazônia Azul, dentre eles:

- o LEPLAC (Plano de Levantamento da Plataforma Continental), através do qual se aferiu, a partir de 1989, os limites exteriores da Plataforma Continental brasileira e os apresentou à ONU em 2004, resultando num importante ganho parcial de mar territorial;

- o REMPLAC (Programa de Avaliação da potencialidade mineral da Plataforma Continental), executado pelo Serviço Geológico do Brasil (CPRM);

- Já o PROAREA (Programa de prospecção e exploração de recursos minerais da área internacional do Atlântico Sul e Equatorial), um desdobramento do REMPLAC, busca identificar reservas minerais para além da Zona Econômica Exclusiva brasileira, com o intuito de reivindicar sua exploração junto à ONU.

${ }^{115}$ Em 2013 a Marinha publicou Amazônia Azul: a última fronteira, obra multilateral sobre as características de nosso mar territorial, onde percorre estes quatro enforques. 
A partir deste planos, o país realiza um extenso inventário das possibilidades cientificas, características ambientais e potencialidade econômicas do mar territorial brasileiro. Tem especial importância Navios científicos que estão sendo adquiridos por Universidades brasileiras.

O país também realiza importantes pesquisas cientificas a partir de suas ilhas oceânicas, como o PROARQUIPELAGO, voltado às ilhas de São Pedro e São Paulo, o PROTRINDADE, relacionado a ilha de Trindade.

Estima-se que o país possua hoje cerca de 40 cursos de graduação e 28 programas de graduação na área de ciências do Mar (TELEMBERG, 2013, p. 119).

Do ponto de vista econômico, destaca-se, antes que nada, a produção de petróleo do présal, que já responde atualmente por mais da metade da produção petrolífera do país. Segundo dados recentes divulgados pela ANP, a produção nacional de petróleo cresceu 14,2\% em janeiro de 2017 em relação a janeiro de 2016. No mesmo período, a produção de gás natural aumentou em 13,1\%. A produção especifica do Pré Sal obteve em janeiro de 2017 um novo recorde mensal, registrando crescimento de $54 \%$ em relação a janeiro de 2016. Já corresponde a 1,588 milhão de BOE diários, mais da metade dos 2,687 milhões de barris produzidos no país (Valor Econômico, 03/03/17).

Some-se ao petróleo e gás, questões econômicas chave como as rotas de comércio e todo o sistema portuário brasileiro, além da indústria pesqueira.

Chegamos então a importância estratégica da Amazônia Azul, a vertente soberania. O mar, ao mesmo tempo que constitui a primeira barreira para o acesso ao território nacional, também constitui uma de suas grandes vulnerabilidades tendo em vista concentrar $95 \%$ do comercio exterior do país.

Um primeiro problema passa pelo monitoramento de tão vasta área. Por isso, é preciso iniciar efetivamente o SisGAAZ (Sistema de Gerenciamento da Amazônia Azul), amplo e moderno sistema que substituirá o antigo sistema, limitado a patrulha de navios da Marinha e às aeronaves de patrulha da Força Aérea Brasileira. Outra questão de enorme relevância estratégica é efetivar o projeto da Segunda Esquadra Naval, já mencionada, e que enfrentará a vulnerabilidade da parte norte do país. 
No que diz respeito à negação do uso do mar e à concentração de forças hostis em nosso litoral, o país precisa manter seus compromissos com o PROSUB (Programa de desenvolvimento de Submarinos), que vem sendo atingido pela crise. Atualmente, por razões orçamentarias, corre o risco de não atingir a meta de lançar ao mar, no terceiro trimestre de 2018, primeiro submarino convencional em construção no projeto de cooperação com a França ${ }^{116}$. Nesta mesma chave, o problema da novo navio aeródromo (“porta-aviões") também é urgente, tendo em vista a desativação do NAe São Paulo.

Por fim, é preciso discutir o problema, do ponto de vista da soberania, relacionado a presença nas ilhas oceânicas. Atualmente de uso tão somente cientifico, deve-se considerar sua utilização militar, sobretudo a ilha de Trindade, um verdadeiro "portaaviões" no meio do Atlântico Sul em meio ao "cordão de ilhas" britânicas, de uso franqueado à OTAN, defronte o litoral brasileiro.

VII -

Tema de grande relevância para a política brasileira de Defesa, dada as características do país, é a posse de vultosos recursos naturais estratégicos num mundo que poderá observar a escassez de parte importante destes recursos num futuro próximo. Diz a PND:

\footnotetext{
"O expressivo aumento das atividades humanas decorrente dos crescimentos econômico e populacional mundiais tem resultado na urbanização desordenada e na ampliação da demanda por recursos naturais. Dessa forma, não se pode negligenciar a intensificação de disputas por áreas marítimas, pelo domínio espacial e por fontes de água doce, de alimentos e de energia. Tais questões poderão levar a ingerências em assuntos internos ou a controvérsias por interesses sobre espaços sujeitos à soberania dos Estados, configurando possíveis quadros de conflito" (2.3.3).
}

Estes cenário - escassez de recursos - nos parece ser a hipótese mais plausível de enfrentamento estratégico do país com potências mundiais nas próximas décadas. Contudo, isto não está posto no atual momento pela orientação atual do governo brasileiro. Sob a presidência de Temer, o Brasil tem não apenas permitido como

\footnotetext{
116 Ver "Programa da Marinha para construir submarinos sofre com crise fiscal" (20/08/2017) em https://oglobo.globo.com/brasil/programa-da-marinha-para-construir-submarinos-sofre-com-crise-fiscal21725347\#ixzz4u45syK2z
} 
incentivado a posse estrangeira de recursos naturais que potencialmente poderão ser objeto de disputa:

- os bilionários programas de vendas de ativos da Petrobras, da Eletrobrás e da Vale do Rio Doce;

- na realização, pela Agência Nacional de Petróleo (ANP), de forma açodada, de quatro leilões de áreas petrolíferas do Pré-Sal em 2017, num quadro de exigências de regras de conteúdo locais frágeis, minando esforço de política industrial no setor e de incentivo a participação de grandes petrolíferas estrangeiras - inclusive estatais;

- pela abertura ao capital estrangeiro do setor de minério, inclusive em faixa de fronteira e na Amazônia, como se viu no episódio da Reserva Mineral de Cobre e seus Associados (Renca), criada em 1984. Some-se a isto, cogitação da liberação de mineração por empresas estrangeiras na faixa de fronteira, atualmente vedada pelo Conselho de Defesa Nacional. Áreas altamente sensíveis a soberania nacional, como a "Cabeça do Cachorro" no noroeste do $\mathrm{AM}^{117}$, rica em metais nobres como Nióbio, às quais se sobrepõem reservas indígenas, seriam concedidas a empresas estrangeiras;

- no anúncio de venda de terras à estrangeiros. Com isso, disse o próprio ministro da Agricultura, Blairo Maggi na Fiesp, poderá ser afetada a produção nas cadeias de milho e de soja a partir de decisão de não-plantio que poderá ser tomada por fundos que adquiram terras e especulem seus resultados na Bolsa de Chicago ${ }^{118}$;

Visando criar canal de escoamento destes recursos naturais, está em curso ampla desnacionalização da posse destes ativos combinado com a possível criação de infraestrutura - também controlada por países estrangeiros -, como é o caso da possível Ferrovia sul-americana em estudo pelos chineses.

Soberanamente, num futuro próximo, o país terá que retomar o controle nacional público ou privado - destes ativos estratégicos e regular sua utilização, de acordo com o interesse nacional. Fazendo, por exemplo, como fazem a OPEP com a oferta de óleo no

\footnotetext{
117 Valor Econômico, 16/02/2017, p. A2

118 Ver http://revistagloborural.globo.com/Noticias/Politica/noticia/2017/02/globo-rural-blairo-maggi-querrestricoes-para-soja-e-milho.html (acessado 07/03/17)
} 
mercado mundial visando determinar o preço; ou a China com o mercado de terras-raras, visando regular a oferta.

Podemos classificar os recursos naturais estratégicos a partir de duas categorias:

- os recursos naturais relacionados a segurança humana, como agua, alimentos e terras cultiváveis;

- os recursos fundamentais à indústria e comercio, como recursos energéticos, recursos minerais e cultivos relacionados a indústria farmacêutica, incluindo certos tipos de $\operatorname{drogas}^{119}$.

Caberá ao Brasil, potência nas duas categorias de recursos estratégicos, regular a oferta e a exploração destes recursos tendo em vista o interesse nacional.

Outro tema que poderá sofrer iniciativas de securitização é das chamadas mudanças climáticas. Tema controverso, tendo em vista haver múltiplas interpretações sobre sua intensidade e até mesmo ocorrência, tem se observado ser parte de uma geopolítica do meio ambiente, relacionado ao debate sobre desenvolvimento. A PND, ao abordar o assunto, faz frágil vinculação com esta possível vinculação estratégica: "Os impactos da "Mudança do Clima" poderão, ademais, acarretar graves consequências ambientais, sociais, econômicas e políticas, exigindo maior capacidade estatal de agir" (2.3.5).

VIII -

A ideia de basear a Defesa Nacional na capacidade de resistir a potenciais ameaças por parte de forças militarmente superiores - isto é, de grandes potências estrangeiras através da centralidade de estruturar capacidade de Dissuasão é aspecto chave da atualização do pensamento estratégico brasileiro no pós-guerra fria. A END de 2012, por exemplo, pauta-se, como primeiro item, por "dissuadir a concentração de forças hostis

119 Ver "Recursos Naturales estratégicos", de Sara Garcia Tasich, disponível em http://www.ieee.es/ Ver ainda KLARE, Michael. The race for what's left: the global scramble for he world's last resources. Metropolitan Books, NY, 2012. 
nas fronteiras terrestres e nos limites das aguas jurisdicionais brasileiras, e impedir-lhes o uso do espaço aéreo nacional" (DEFESA, 2012, p. 47).

Classicamente, a doutrina da dissuasão foi estruturada tendo em vista a maior dos atributos dissuasórios que é a posse de armas nucleares ${ }^{120}$. Tendo o Brasil, porém, renunciado a possibilidade de possuir este artefato, com a assinatura do Tratado de nãoproliferação de armas nucleares (TNP), em 1998, cabe ao país constituir um sistema de dissuasão baseado em forças convencionais.

Na versão última da END, apresenta-se assim a questão da dissuasão:

“A Capacidade de Dissuasão, por sua vez, configura-se como fator essencial para a Segurança Nacional, na medida em que tem como propósito desestimular possíveis agressões. Sustenta-se nas condições que possui a Nação de congregar e aplicar sua Capacidade de Proteção e de Pronta-resposta, no caso de eventuais ações hostis contra a soberania e os legítimos interesses do Brasil" (3.1, END, 2016).

Um dos atributos centrais da estratégia de dissuasão é a posse dos submarino a propulsão nuclear. Outro, é a existência de poderosos sistema antiaéreo, o qual após ensaio realizado $^{121}$, continua tema em aberto. Também a capacidade de interceptação aérea é atributo indispensável, pelo que, o processo de aquisição e desenvolvimento do avião de caça Gripen é fundamental ${ }^{122}$.

A estruturação de uma sistema de dissuasão complementa-se, doutrinariamente, o fortalecimento da capacidade de resistência, baseados nos conceitos de flexibilidade e elasticidade. Assim, para fortalecer a capacidade de dissuasão e resistência impõe-se o imperativo da elasticidade das Forças Armadas. Elasticidade pode ser definida como "capacidade de aumentar rapidamente o dimensionamento das forças militares quando as circunstancias exigirem”. Para tal, "a base derradeira da elasticidade é a integração das Forças Armadas com a Nação" (DEFESA, 2008, p.23)

A versão de 2008 da END é bastante precisa ao identifica a base desse desdobramento do poder militar nacional: “A base da defesa nacional é a identificação da Nação com as

120 Ver BEAUFRE, General A. Dissuasion y Estrategia. Instituto de Estudios Politicos, Madrid, 1966.

121 O Brasil cogitou parceria com a Rússia, país de forte tradição antiaérea, para aquisição e transferência de tecnologia. Porém, por razões todavia obscuras - não se sabe ao certo se por opções técnicas ou ideológicas - se abortou a iniciativa.

${ }^{122} \mathrm{~A}$ partir do qual espera-se que o país adquira capacidade de projetar seus próprio avião de caça nacional de $5^{\mathrm{a}}$ geração. 
Forças Armadas e das Forças Armadas com a Nação" (DEFESA, 2008, p.37). Adicionalmente, identifica no povo brasileiro o compromisso principal com a causa da independência e da soberania nacional. Diz o texto que "A Nação brasileira foi e é um projeto do povo brasileiro; foi ele que abraçou a ideia de nacionalidade e lutou para converter a essa ideia os quadros dirigentes e letrados. Este fato é a garantia profunda da identificação da Nação com as Forças Armadas e destas com a Nação" (DEFESA, 2008, p.40)

A END de 2008 menciona ainda como vantagem estratégica característica própria dos brasileiros: “[...] a capacidade de improvisação e adaptação, o pendor para criar soluções quando faltam instrumentos, a disposição de enfrentar as agruras da natureza e da sociedade, enfim, a capacidade quase irrestrita de adaptação que permeia a cultura brasileira" (DEFESA, 2008, p.40)

A ideia da incorporação doutrinaria de técnicas de guerra de guerrilhas nas forças convencionais aparece na END de 2008 na seguinte forma: "exigirá, sobretudo na Força Terrestre, que as forças convencionais cultivem alguns predicados atribuídos a forças não-convencionais" (DEFESA, 2008, p.15)

Por fim, note-se ainda, na versão de 2008, a preocupação com os riscos subjacentes à soberania sobre a Amazônia e a doutrina militar em sua defesa:

\footnotetext{
"Os imperativos de flexibilidade e de elasticidade culminam no preparo para uma guerra assimétrica, sobretudo na região amazônica, a ser sustentada contra inimigo de poder militar superior, por ação de um país ou de uma coligação de países que insista em contestar, a pretexto de supostos interesses da humanidade, a incondicional soberania brasileira sobre sua Amazônia. [...] A guerra assimétrica, no quadro de uma guerra de resistência nacional, representa uma efetiva possibilidade da doutrina aqui especificada" (DEFESA, 2008, p.27).
}

Em seu conjunto, a definição de uma estratégia de dissuasão seguida de uma estratégia de resistência, situa, nesse período histórico, as características que devem adquirir as Forças Armadas brasileiras tendo em vista sua missão precípua - sem obviamente abandonar alguma capacidade ofensiva e expedicionária.

O povo brasileiro tem larga tradição de salvaguarda sua independência e soberania em momentos em que esta esteve em questão. Do ponto de vista militar, os brasileiros forjaram, pelas suas características nacional vistas acima, uma forma própria de fazer a guerra denominada guerra brasílica. Consiste em privilegia o atributo da manobra, da surpresa e da emboscada. 
Foi assim que os heróis de Guararapes logram derrotar a principal potência da época, a Holanda, nas duas guerras de expulsão dos batavos de Pernambuco ${ }^{123}$. Em especial a figura de Antônio Dias Cardoso, comandante de uma companhia de emboscada nas guerras de Guararapes precisa ser enaltecida ${ }^{124}$. A guerra brasílica foi empregada em diversos momentos na história militar brasileira ${ }^{125}$; o Brasil deve, no contexto da educação cívica e patriótica de seus povo, buscar difundir estes momentos de gloria militar de sua civilização.

IX -

Desde a Estratégia Nacional de Defesa de 2008 aparece a orientação de "estruturar o potencial estratégico em torno de capacidades" (DEFESA, 2008, p.16). A ideia do planejamento por capacidade e não por inimigos, soma-se ao necessário avanço do atributo da interoperabilidade das três Forças singulares. Com base nisso, por exemplo, recém se estruturou, no âmbito da escola Superior de Guyerra (ESG), um Centro de estudos de Doutrinas de Operações Conjuntas.

Assim, as Forças singulares devem aprimorar sua capacidade de emprego conjunto, por meio da interoperabilidade. Neste sentido deverão adestrar-se para emprego na defesa da Pátria num cenário internacional caracterizado por alto grau de indeterminação e imprevisibilidade de ameaças ao país, que exige o imperativo do planejamento baseado em capacidades.

Instituições fundadoras da nacionalidade - caso da Marinha do Brasil e do Exército Brasileiro - e de nossa construção moderna - caso da Força Aérea Brasileira -, nossas Forças singulares são instituições perenes e tradicionais, dotadas de valores e tradições que orgulham os brasileiros.

\footnotetext{
${ }^{123}$ Dentre as diversas obras a descreverem as guerras de Guararapes, a que consideramos mais completa do ponto de vista da análise das características da guerra brasílica é a de MOREIRA BENTO, Claudio. As batalhas de Guararapes - descrição e análise militar. Universidade Federal de Pernambuco, Recife, 1971.

124 Antônio Dias Cardoso é o patrono das forças especiais do Exército brasileiro, cujas guarnições situamse em Goiânia (GO) e Niterói (RJ).

125 Uma descrição histórica exaustiva e detalhada está em MOREIRA BENTO, Claudio \& CAMINHA GIORGIS, Luiz Ernani. Brasil: lutas contra invasões, ameaças e pressões externas. Academia de História Militar Terrestre do Brasil, Resende, 2014.
} 
Contudo, para dar cabo aos enormes desafios contemporâneos, seja aqueles todavia vinculados à construção, à integração e ao desenvolvimento nacional, sejam aqueles ligados a sua função precípua - defesa armada da soberania e integridade nacional precisarão intensificar sua capacidade de operar em conjunto, visando obter ganhos de eficiência e multiplicação de capacidade de emprego em suas missões.

Mais forte será a Defesa Nacional, quanto maior for a capacidade de elasticidade de suas Forças Armadas e de Mobilização Nacional. Nesse sentido, a integração povo brasileiro - Forças Armadas, proposta nos documentos de Defesa vigentes, é uma necessidade imperiosa para a grandeza da Pátria.

Tradicionalmente as Forças Armadas se preparavam para o emprego considerando "hipóteses de guerra", mais recentemente denominadas "hipóteses de emprego". Estas, tinham por base a identificação de inimigos claros, em áreas geográficas delimitadas; mais recentemente, entretanto, a doutrinas modernas das Forças Armadas no mundo e também no Brasil, desde a edição da Estratégia Nacional de Defesa, tem proposto que estas se organizem visando enfrentar ameaças diversas e difusas, de origens variadas, organizando seu planejamento assim, baseado em capacidades e não em inimigos.

$\mathrm{Na}$ END vigente (2012), a Dtz Nr 16 determina "estruturar o potencial estratégico em torno de capacidades", observando que "convém organizar as Forças Armadas em torno de capacidades, não em torno de inimigos específicos. O Brasil não tem inimigos no presente. Para não tê-los no futuro, é preciso preservar a paz e preparar-se para a guerra".

Essa orientação se justifica, antes de nada, pelo fato de que não se vislumbra, no entorno estratégico brasileiro - conformado, em seu círculo concêntrico mais estreito, pelos vizinhos à Oeste (América do Sul) e a Leste (África ocidental) - qualquer tipo de ameaça por parte de Estados Nacionais, quer pela superioridade militar brasileira, quer pela prevalência de uma visão comum pela integração regional. Assim, em seu entorno o Brasil privilegia relações de cooperação para o desenvolvimento comum.

Os documentos vigentes observam ameaças não nominadas por parte de potências (ou coalizão de potencias) com capacidade militarmente superior a do Brasil. Em razão disto, como se viu no intem anterior, dá-se prioridade à estratégia de dissuasão, na qual calculo estratégico destas potências observem que o custo de agredir o Brasil os desencorajarão de fazê-lo. 
Assim, o Brasil deve ser preparar primordialmente, para obter capacidades no sentido de desencorajar aventuras militares das grandes potências baseadas em capacidade aeronavais. Possivelmente, uma agressão militar ao Brasil se daria por meio aéreo, com ataques a instalações estratégicas e concentrações econômicas e produtivas combinada com bloqueio marítimo de portos e rotas de comércio.

Diante destas possibilidade, devemos observar tendências da guerra moderna, como se vê no debate a respeito do TO pacífico/asiático, entre a estratégia chinesa de negação de acesso e a resposta norte-americana conhecida como "terceiro offset". São tendências que poderão, num futuro incerto, aplicar-se ao TO do Atlântico Sul, sobretudo se confirmadas tendências de guerras por domínio de recursos naturais.

Também vimos que o Brasil deve preparar-se para estratégias de guerra de resistência, capacidade que poderá ser requerida para a defesa da Pátria num segundo momento. Aqui, fala alto nosso domínio histórico desta capacidade, no contexto das "guerras brasílicas", que dão origem a uma doutrina militar brasileira autóctone. Falamos aqui da "guerra de mato", da qual falou o patriarca José Bonifácio de Andrada e Silva; antes, nas campanhas de Pedro Teixeira na expulsão de invasores estrangeiros na Amazônia ou nas ações da campanha dos Guararapes, das "guerras de emboscada", sob comando do bravo capitão Antonio Dias Cardoso; ou nas "guerras gaúchas" protagonizadas pelas campanhas no sul do país.

Hodiernamente, o planejamento das Forças Armadas baseado em capacidades derivadas da estratégia de dissuasão e da estratégia de resistência, com alto grau de interoperabilidade, é a orientação fundamental que devem constar dos documentos estratégicos de Defesa Nacional.

$* * *$

Com esta ampla revisão do problema do planejamento nacional, inicialmente no seu sentido mais amplo, de grande planos que embasaram projetos nacionais, seguida da revisão da tradição de planejamento estratégico-militar e, por fim, com a revisão das políticas de Defesa nacional, damos por concluído este último capítulo. Passemos a seguir às conclusões deste trabalho. 


\section{CONCLUSÕES}

No repasse sistemático das contribuições clássicas sobre os atributos constitutivos do Poder Nacional, que permitem a um país possui uma Grande Estratégia num ambiente internacional em que suas unidades constitutivas encontram-se em ambiente de permanente disputa, observamos as bases que as nações se defrontam para atingir a condição de potência.

Esta Tese busca revisar os conceitos clássicos das questões acima tendo em vista o projeto brasileiro. Levamos aqui em consideração de forma mais elevada a citada orientação metodológica de Hans W. Weigert para quem "há tantas geopolíticas quantos os sistemas estatais em luta sob condições geográficas [... e, portanto] Cada nação tem a geopolítica que pretende $[\ldots] "$.

Levando em consideração o projeto brasileiro de potência, e tendo em vista as definições originarias de Kjéllen quanto aos atributos para esta condição - espaço, liberdade de movimento e coesão interna - a primeira conclusão a que chegamos ao finalizar este trabalho é que, após ciclos de agregação de Poder Nacional - e, portanto, do caminho para atingir a condição de potência -, o Brasil começou a registrar perda líquida destes atributos.

Cabe aqui um esclarecimento introdutório importante. A adesão do projeto nacional a causa de realização do atributos de potência, reside, no caso brasileiro, à objetivos endógenos: a maximização do desenvolvimento nacional tendo em vista objetivos civilizacionais. Contudo, esta busca por maximizar o desenvolvimento defronta-se com obstáculos de natureza exógena. O enfrentamento destes obstáculos, nesta quadra histórica, exige que a conquista brasileira de seus atributos de potência se realize apoiado sobretudo nas imensas potencialidade não decantadas. Mas também defrontando-se com um sistema internacional onde as potências estabelecidas agem fortemente no sentido de congelamento do status quo - ou do poder mundial, para utilizarmo-nos da feliz expressão de Araújo Castro.

Nossa ambição de potência não relaciona-se ao preceito ratzeliano de expansão orgânica ou perecimento. Noutras palavras, não há pretensões de natureza imperialista. Somo, como dissemos, um país satisfeito territorialmente. Mais que isso: ocupar a totalidade do território nacional, integrando-o e dele se apropriando tendo em vista a centralidade do 
desenvolvimento e do bem-estar de sua própria civilização, todavia é missão inconclusa dos brasileiros.

Portanto, uma primeira conclusão é que, para atingir condição de potência no sistema internacional, o Brasil deve, antes que nada, olhar para dentro. Depois - ou melhor, concomitantemente - removendo obstáculos de natureza exógena. Estes, por certo são muitos e alguns deles vimos ao longo deste trabalho. As tendências por primarizar, dentro de uma lógica colonial, a economia brasileira abundante em matérias primas; as características financeirizadas do capitalismo contemporâneo e suas pressões antiprodutivistas; as profundas assimetrias que marcam as relações de comercio e as condições de forças (poder militar) na arena internacional.

Voltemos a síntese de Kjéllen sobre atributos de potência. Quanto ao atributo mais estável, dizia Morgenthau, a geografia, o Brasil recebe a herança extraordinária dos seus antepassados que é o imenso território-continente - conquistado, diga-se, não por dádiva, mas com luta diplomática e militar, ademais do utti possidetis que os bandeirantes paulistas desbravam embrenhando-se por matas inóspitas.

Contudo, nos fatores variáveis, liberdade de movimento e coesão interna, o Brasil regride fortemente, após avanços substanciais, especialmente no século XX.

Podemos dizer que assistimos assim a uma erosão acelerada do poder nacional nos últimos anos, fruto de falta de coesão interna e, consequente, perda de liberdade de movimento. No capitulo terceiro deste trabalho, o problema da coesão interna como fator estratégico, creio, foi fartamente demonstrado. Cabe aqui, nestas conclusões, uma síntese e uma descrição sobre perda liquida de liberdade de movimento.

Um síntese disto:

1) Brasil registra retrocessos dramáticos em sua capacidade de projeção de poder “não-militar" -portanto, do enfrentamento de obstáculos exógenos a obtenção de sua condição de potência. Primeiro, porque há notável retrocesso em nossa presença junto a nosso entorno estratégico - área geográfica que nos circunda e que declaramos especial interesse em projetar poder e influência. Após utilizarmo-nos de mecanismos clássicos "não militares" de projeção de poder, por meio do "braço empresarial" do Poder Nacional, de atributos de soft-power e 
da promoção de alianças variáveis, fomos rapidamente abatidos neste movimento estratégico.

A falta de coesão interna sobre essa política de agregar poder e projetar influência no entorno geográfico, talvez tenha se revelado como a vulnerabilidade fundamental que permitiu, por exemplo, que a ofensiva contra a presença empresarial brasileira em seu entorno fosse deflagrada a partir de informações difundidas, como se viu, por relatório de governo estrangeiro, diretamente interessado em debilitar a projeção brasileira nesta área geográfica em que, igualmente, disputa influencia. Forte lição a extrair aqui para a retomada do projeto de potência num futuro próximo.

2) A crise brasileira atual recaiu mais fortemente sobre os motores mais dinâmicos - ou fatores de dinamismo - da economia nacional. Vejamos:

- o setor de Petróleo e Gás, que correspondia, antes da crise, a mais de dez por cento do PIB brasileiro e se encontrava em franca expansão, tendo em vista ser o Brasil a mais nova e promissora fronteira mundial de hidrocarboneto. A Petrobras, grande empresa controlada pelo Estado brasileiro foi encolhida e segue em marcha batida na desconstrução de sua presença em sua própria cadeia produtiva. O desmantelamento das políticas de conteúdo local, para além de ajustes que deveriam necessariamente ser feitos, resultará, se não revertida, no desperdício de possibilidade de contribuição efetiva para um processo de reindustrilização nacional.

- o setor de agronegócio, outro grande fator de dinamismo nacional, é frequentemente intimidado por pressões protecionistas e pela ideologia ambientalista promovidas por ONGs paraestatais dos países concorrentes. Defronta-se ainda com difíceis condições da deteriorada infraestrutura nacional. Eis que, no curso da crise atual, foi atingido num de seus núcleos mais dinâmicos, o setor de proteína animal. Primeiro, numa desastrada - e todavia obscura operação que abalou sua credibilidade no exterior. Depois, no desmonte da maior empresa mundial de proteína animal, que havia conquistado espaços estratégicos - em termos de segurança alimentar - nos países centrais. 
- na desconstrução da altamente competitiva cadeia de empresas de construção civil e engenharia, altamente competitiva internacionalmente e fator de projeção empresarial brasileira em áreas geográficas de seu interesse. Muitas destas empresas, sobretudo a maior delas, entra-se hoje desmoralizada e altamente endividada, inclusive com vultosas multas e processos legais num grande números de países.

- após promissora aposta brasileira, retrai o processo de organização de uma diversificada base industrial de Defesa, fortemente apoiada em capital nacional. A carteira de projetos estratégicos das Forças Armadas, encomendas que iam permitindo a estruturação desta cadeia produtiva dinâmica e intrinsicamente inovativa, é retardada ou mesmo descontinuada. A Industria Naval civil, de capacidade intrinsecamente dual, é descontruída. Os pesados investimentos das empresas de construção civil na constituição de empresas o setor de Defesa, praticamente encerrou-se. Mesmo a EMBRAER, caso de sucesso remanescente de decisões tomadas no início da constituição de nosso sistema de CT\&I, sofre dificuldades que limitam sua capacidade de expansão, passando a depender cada vez mais do mercado externo altamente competitivo e submetido a regras não comerciais.

3) Definham os "núcleos duros" do Poder Nacional e os instrumentos fundamentais do Estado brasileiro induzir e promover o desenvolvimento nacional. Listemolos:

- derivado da crise fiscal do Estado brasileiro, o país se auto impôs o chamado teto de gastos, pelo qual a única obrigação que não está ameaçada, é o pagamento da dívida pública. Afeta-se de sobremaneira sobretudo a capacidade investimento do estado e portanto, de indução do desenvolvimento;

- atinge-se duramente o BNDES (Banco Nacional de Desenvolvimento Econômico e Social), que atingira tamanho superior ao do próprio Banco Mundial e possui potencial de alavancar cadeias produtivas dinâmicas da economia brasileira. Especialmente dramática é o fim de suas linhas de financiamento à 
produção e a infraestrutura subsidiada - a Taxa de Juros de Longo Prazo - e a instituição de uma taxa de mercado. Elimina-se pratica corrente na história econômica que constitui o caminho para o desenvolvimento;

- instala-se uma crise de graves proporções no sistema de ciência, tecnologia e inovação. O Fundo Nacional de Desenvolvimento Cientifico e Tecnológico (FNDCT), pedra angular do sistema brasileiro, está no seu menor nível orçamentário desde 2006, afetando de forma expressiva a capacidade de financiamento de áreas "portadoras de futuro" para um novo dinamismo da economia brasileira. Componente mais sensíveis do sistema de CT\&I, o instrumento de Subvenção Econômica - recursos a fundo perdido, operados pela Finep, no qual o país financia pesquisas em áreas de fronteira que não deslancharão sem aporte público inicial - passa por forte recuo.

- é descontinuada a política industrial, num contexto em que a longa semi estagnação que ocorre desde o fim do ciclo nacional-desenvolvimentista (anos 1980), resultou numa brutal queda da participação da Indústria de transformação no PIB: desde 1985, quando atinge 21,6\% do PIB, seu auge, ocorre uma regressão profunda na estrutura produtiva brasileira, que em 2014 chega a 10,9\%, mesmo patamar de 1947. Há analistas que veem indicações que hoje, o número já poderia mostrar uma participação inferior a um digito, numa regressão aos índices do início do esforço industrializante (Revolução de 1930) e talvez similar ao início do século $\mathrm{XX}$, quando o país ainda era uma nação predominantemente agrária, dependente das exportações de café. Isso ocorre incrivelmente num contexto em que as principais economias do mundo voltam-se a estruturação de políticas industriais ncoradas na inovação tendo em vista ingressas no movimento de transformações das forças produtivas conhecido como Indústria 4.0 ou manufatura avançada.

- por fim, a economia brasileira vive profundo processo de desnacionalização. Estão em curso gigantescos programas de vendas de ativos da Petrobras, da Eletrobras e da Vale do Rio Doce; a Agência Nacional de Petróleo (ANP), passa a promover, de forma açodada, leilões de áreas petrolíferas essencialmente voltadas à empresas estrangeiras, tendo em vista a fragilização da Petrobras; propõe-se a liberação de mineração por empresas estrangeiras na faixa de 
fronteira, atualmente vedada pelo Conselho de Defesa Nacional; anuncia-se a venda de terras à estrangeiros.

4) Por fim, mas não menos importante, a perda liquida de poder nacional, acima demonstrada, resulta numa elevada perda de autoestima dos brasileiros e de sua confiança em relação ao futuro.

$* * *$

As questões acima apontadas, pontuam desafios que a nação se defrontará para a retomada de sua projeto de potência, em síntese, de seu projeto nacional.

A síntese conclusiva possível neste momento, é que mais que nunca será necessário aos brasileiros, sobretudo às suas elites formuladoras das bases do pensamento estratégico, redobrarem os estudos dos caminhos percorridos por países que ascenderam a condição de potência e das lições a extrair nestas experiências. Pensamos que esta Tese, modestamente, apresenta uma contribuição neste sentido. Este foi o desafio a que nos propomos ao iniciar esta linha de investigação, a qual, se por certo não chega a seu ponto final - sobretudo, tendo em vista o dramático quadro acima -, tampouco deixou de chagar a um estágio sólido, ao identificar conceitos e experiências e sugerir caminhos para um caminho virtuoso para o Brasil. 


\section{BIBLIOGRAFIA}

ACIOLY, L. \& MORAES, R.F. Prospectiva, estratégias e cenários globais - visões de Atlântico Sul, África Lusófona, América do Sul e Amazônia. Brasília, IPEA, 2011

ALMEIDA PINTO, J. R. de. (Org.). Reflexões sobre defesa e segurança: uma estratégia para o Brasil. Brasília: Ministério da Defesa, 2004 (Pensamento brasileiro sobre defesa e segurança). 4 volumes.

AMADO, Rodrigo. Araujo Castro. Editora Universidade de Brasília, Brasília, 1982.

ANDRADA E SILVA, José Bonifácio. Obras cientificas, políticas e sociais (3 tomos). Brasília: Câmara dos Deputados, 2006.

ANJOS, João Alfredo dos. José Bonifácio, primeiro chanceler do Brasil. Brasília: Fundação Alexandre de Gusmão, 2007.

ARON, Raymond. Paz e Guerra entre as Nações. Editora Universidade de Brasília. Brasília: 1986.

ARRUDA, Inácio. Discurso proferido durante a solenidade de homenagem aos 250 anos de José Bonifácio, Patriarca da Independência. Plenário do Senado Federal, em 13 de junho de 2013. Disponível em http://grabois.org.br/portal/noticia.php?id_sessao=8\&id_noticia=11482

AMORIM, Celso. A atualidade de José Bonifácio. Folha de São Paulo, 08/07/2013, p. A3.

Paulo, 2016.

A Grande Estratégia do Brasil. Funag/Editora Unesp, Brasília/São

AYERBE, Luis Fernando. De Clinton a Obama: política dos Estados Unidos para a América Latina. Editora Unesp, Programa de Pós Graduação San Tiago Dantas, São Paulo, 2009.

AMARAL GURGEL, José Alfredo. Segurança e democracia, uma reflexão sobre a doutrina da Escola Superior de Guerra. Rio de Janeiro, Editora Biblioteca do Exército / José Olympio Editora, 1975. 
BEMERGUY DE ALBUQUERQUE, E. "Infraestrutura para a Integração e o desenvolvimento da América do Sul". Mimeo, 2013.

BACKHEUSER, Everardo. A geopolítica geral e do Brasil. Biblioteca do Exército Editora, Rio de Janeiro: 1952

BAUMANN, Ricardo (org.). O Brasil e os demais BRICs - comércio e política. Cepal / IPEA, Brasília, 2010.

BATISTA JÚNIOR, Paulo Nogueira. Paulo Nogueira Batista: pensando o Brasil. Fundação Alexandre de Gusmão, Brasília, 2009.

BARBOSA, Rubens. Mercosul e a integração regional. Fundação Memorial - Imprensa Oficial. São Paulo, 2009.

BARRIOS, Miguel Angel. Diccionario latinoamericano de seguridad y geopolitica. Editorial Biblos, Buenos Aires: 2009.

BALAKRISHNAN, Gopal (org.). Um mapa da questão nacional. Rio de Janeiro, Editora Contraponto, 2008.

BEAUFRE, André. Introdução à estratégia. Biblioteca do Exército Editora, Rio de Janeiro, 1998.

1966.

.Dissuasion y Estrategia. Instituto de Estudios Politicos, Madrid,

BECKER, Berta. Geografia - Manual do Candidato. Fundação Alexandre de Gusmão, Brasília, 2010.

BONFIM, Uraci Castro. Geopolítica. Escola de Comando e Estado-Maior do Exército, Brasília, 2005.

BRASIL. ESTRATEGIA NACIONAL DE DESESA. Paz e segurança para o Brasil in www.defesa.gov.br, acessado em dezembro de 2008. 
BRASIL. Livro Branco de Defesa Nacional - LBDN. Brasília, 2012. Disponível em: https://www.defesa.gov.br/arquivos/2012/mes07/lbdn.pdf Acessado em 01 nov 2012

BRASIL. Estratégia Nacional de Defesa - END. Brasília, 2012. Disponível em: https://www.defesa.gov.br/arquivos/2012/mes07/end.pdf Acessado em 01 nov 2012

BRASIL. PND - Política Nacional de Defesa, Brasilia, 2017. Disponível em http://www.participa.br/estrategia-nacional-de-defesa-end/documentos-estrategicos-dedefesa/pnd-politica-nacional-de-defesa/pnd-politica-nacional-de-defesa (acessado em 01/08/2017)

BRASIL. Estratégia Nacional de Defesa - END. Brasília, 2017. Disponível em http://www.participa.br/estrategia-nacional-de-defesa-end/documentos-estrategicos-dedefesa/end-estrategia-nacional-de-defesa/end-estrategia-nacional-de-defesa (acessado em 01/08/2017)

BRASIL. Livro Branco de Defesa Nacional - LBDN. Brasília, 2017. Disponível em http://www.participa.br/estrategia-nacional-de-defesa-end/documentos-estrategicos-dedefesa/lbdn-livro-branco-nacional-de-defesa/lbdn-livro-branco-de-defesa-nacional (acessado em 01/08/2017)

BRICK, E. O planejamento da defesa para um futuro incerto, parte I e II. Disponível em http://www.defesa.uff.br/index.php/analises/31-politica-e-estrategia-de-defesa/341-oplanejamento-da-defesa-para-um-futuro-incerto-parte-1 http://www.defesa.uff.br/index.php/analises/31-politica-e-estrategia-de-defesa/348-oplanejamento-da-defesa-para-um-futuro-incerto-parte-ii (acessados em 30/11/2015).

BRUSTOLIN, V. M. Inovação e desenvolvimento via Defesa nacional nos EUA e no Brasil. Tese de doutorado apresentada junto a UFRJ. 2014, 148 p.

BRZEZINSKI, Zbigniew. El gran tablero mundial - La supremacia estadunidense y sus imperativos geoestratégicos. Paidós. Barcelona, 1998.

York: Basic Books, 2012.

. Strategic Vision. America and the crisis of global Power. New . EUA - URSS, o grande desafio. Editorial Nordica, Rio de Janeiro: 1986. 
BONIFÁCIO, A Revista do Brasil. Publicação do Instituto José Bonifácio, números de 01 a 06, publicados entre outubro de 2003 a março de 2005.

CABRAL, Severino. Brasil, Megaestado - nova ordem mundial multipolar. Rio de Janeiro, Editora Contraponto, 2004.

CAMPOS, Roberto. Economia, planejamento e nacionalismo. Rio de Janeiro: APEC, 1963.

CARMONA, Ronaldo. "Geopolítica clássica e Geopolítica brasileira contemporânea: Mahan, Mackinder e a "grande estratégia" do Brasil para o século XXI". Dissertação de Mestrado. Universidade de São Paulo (USP), 2012.

O Brasil esboça sua "grande estratégia" - notas sobre a Política, a Estratégia e o Livro Branco de Defesa Nacional. Revista Princípios, São Paulo, n. 121, p. 14-21, out./Nov. 2012

Formação social brasileira: uma introdução ao debate. Leitura crítica de Casa Grande e Senzala, Raízes do Brasil e Formação do Brasil Contemporâneo. Escola de Sociologia e Política de São Paulo, São Paulo, Mimeo, 2006.

Bonifácio, gênese do pensamento nacional in Revista Tensões Mundiais. Fortaleza: Editora UECE, 2014.

Desafios ao adensamento da projeção brasileira em seu entorno estratégico. Defesa da Amazônia: VII ENABED. Álvaro Dias Monteiro; Erica C. A. Winand; Rogério Franco Goldoni (organizadores). São Cristóvão, SE: Editora UFS, 2014a, páginas 343-376.

O retorno da Geopolítica: a ascensão dos BRICS in Revista Austral. Porto Alegre, EdUFRGS, 2014.

Revisitando a experiência do ISEB. Revista Princípios, São Paulo, n. 80, p.76-79, ago./set. 2005.

. A ascensão brasileira em xeque. Revista Princípios, São Paulo, n.129, p.99-105, fev./mar. 2014

Com a Cúpula de Fortaleza, BRICS aceleram tendência a um mundo policêntrico. Revista Princípios, São Paulo, n.132, p.51-57, ago./set. $2014 \mathrm{c}$

Apontamentos geopolíticos sobre os desafios para o aprofundamento da Integração Sul-Americana. Brasília, Câmara dos Deputados, 2012. 
42, jun./jul. 2014c

A geopolítica do BRICS. Revista Princípios, São Paulo, n.131, p.37-

Notas sobre Estratégia de Defesa e Estratégia de Industrialização. Apresentação no Seminário "Os Projetos Estratégicos das Forças Armadas: contribuição ao desenvolvimento nacional”. Câmara dos Deputados, Brasília, 06/05/2014.

Submarino nuclear brasileiro: a busca de autonomia estratégica e tecnológica-industrial. Mimeo, 23pgs, 2014.

CARRASCO BAÚZA, Lorenzo \& LINO, Geraldo Luís no texto "A influência do sistema americano de Economia Política no Brasil", que integra a obra Cartas da Economia Nacional contra o Livre Comércio, Editora Capax Dei, 2009.

CNI / FIRJAN. 200 anos de Indústria no Brasil - de 1808 ao século XXI, Edição de 2008.

CHASE, R., HILL, E. and KENNEDY, P. The Pivotal States: a new framework for U.S. Policy in the developing world. New York: W. W. Norton \& Company, 1999. 444 p.

COHEN, Saul B. Presidential Adress. Global Geopolitical Change in the Post-Cold War Era. Annals of the Association of American Geographers, 81(4), 1991, pp. 551-580.

CAMARANO, Ana Amélia (org.). Novo regime demográfico - uma nova relação entre população e desenvolvimento? Rio de Janeiro, IPEA, 2014.

CARVALHO, Delgado de \& CASTRO, Therezinha de. Atlas de Relações Internacionais. IBGE, Conselho Nacional de Geografia, 1960.

Distribuidora Record. Rio de Janeiro, 1971.

Relações internacionais. Biblioteca do Exército e Geopolítica, princípios, meios e fins. Biblioteca do Exército Editora, Rio de Janeiro, 1999.

Nossa América - geopolítica comparada. Biblioteca do Exército Editora, Rio de Janeiro, 1994.

José Bonifácio e a Unidade Nacional. Rio de Janeiro,

Biblioteca do Exército, 1984.

CERVO, Amado Luiz \& BUENO, Clodoaldo. História da política exterior do Brasil. Editora UnB. Brasília, 2008. 
COSTA FRANCO, Álvaro de. Documentos da política externa independente. Volume I e II. Fundação Alexandre de Gusmão, Brasília, 2007 e 2008.

COSTA FREITAS, Jorge Manoel. A Escola Geopolítica Brasileira. Rio de Janeiro, Biblioteca do Exército Editora, 2004.

COSTAS VARGAS, João Augusto. Um mundo que também é nosso. O pensamento e a trajetória diplomática de Araújo Castro. Brasília, Funag, 2013.

CLAUSEWITZ, Carl von. Da Guerra. São Paulo, Editora Martins Fontes, 2010.

CLINE, Ray S. World Power Assessment 1977. A calculus of strategic drift. Washington D.C, The Center for Strategic and International Studies, 1977.

COSTA, Darc. Fundamentos para o Estudo da Estratégia Nacional. Editora Paz e Terra. São Paulo, 2009.

Estratégia Nacional - A cooperação sul-americana como caminho para a inserção internacional do Brasil. Rio de Janeiro: Editora L\&PM Editores, 2003.

COSTA, Emília Viotti da. Da Monarquia à República. Momentos decisivos. São Paulo: Editora Unesp, 1998b

COSTA RIBEIRO, Wagner. Geografia política da água. São Paulo, Editora Annablume, 2008 .

COSTA, Wanderley Messias da. Geografia Política e Geopolítica. Edusp. São Paulo, 2008.

: O Brasil e a América do Sul: Cenários Geopolíticos

e os Desafios da Integração in Segurança \& Defesa Nacional - da competição à cooperação regional. Eliézer Rizzo de Oliveira (org.). Fundação Memorial da América Latina. São Paulo, 2007.

COUTO E SILVA, Golbery. Geopolítica do Brasil. Editora José Olympio. Rio de Janeiro: 1967.

Conjuntura política nacional, o poder executivo e geopolítica do Brasil. Livraria José Olympio Editora, Rio de Janeiro, 1981.

Escola Superior de Guerra, 1956.

Planejamento do fortalecimento do potencial nacional. 
Cinquenta grandes estrategistas das relações internacionais. Martin Griffiths, Editora Contexto, 2004.

COUTAU-BÉGARIE, Hervé. Tratado de Estratégia. Rio de Janeiro, Escola de Guerra Naval, 2010.

DEL VECCHIO, Ângelo (org.). Política Internacional e Hegemonia - Brasil e Estados Unidos no contexto da globalização. Editora Sociologia e Política, São Paulo, 2010. Capitulo I, "Notas sobre o conceito de potência", p.21-38.

DEFESA, Ministério da. Glossário das Forças Armadas, $5^{\mathrm{a}}$ edição, 2015.

DINIZ, Eugenio Diniz. Política Internacional: guia de estudos das abordagens realistas e da balança de poder. Editora PUC Minas, 2007.

DOUHET, Giulio. O domínio do ar. Editora Itatiaia e Instituto Histórico Cultural da Aeronautica. Belo Horizonte - Rio de Janeiro, 1988.

DONADIO, Marcela \& TIBLIETTI, Maria da Paz. Atlas 2010. Buenos Aires, RESDAL, 2010.

DINIZ, Eugenio. Política internacional - guia de estudos das abordagens realistas e da balança de poder. Editora PUC Minas, Belo Horizonte: 2007.

\& PROENÇA JÚNIOR, Domício \& RAZA, Salvador Ghelfi. Guia de Estudos de Estratégia. Jorge Zahar Editor, Rio de Janeiro, 1999.

DIÉGUES, Fernando. A revolução brasílica - O projeto político e a estratégica da independência. Rio de Janeiro: Objetiva, 2004.

DOLHNIKOFF, Miriam. O projeto nacional de José Bonifácio. Revista Novos Estudos, novembro de 1996, p. 121-141.

ESG (Escola Superior de Guerra). O General Meira Mattos e a Escola Superior de Guerra. Rio de Janeiro, ESG, 2007.

. Fundamentos teóricos. Rio de Janeiro, ESG, 1983.

. O General Meira Mattos e a Escola Superior de Guerra.

Rio de Janeiro, ESG, 2007 
FUNAG. O Brasil, os BRICS e a Agenda Internacional. Brasília: FUNAG, 2012. 344 P.

FERREIRA SIMÕES, Antonio José. Integração: sonho e realidade na América do Sul. Fundação Alexandre de Gusmão, Brasília, 2011.

FERREIRA, F.R.G. O Sistema do Tratado da Antártica: evolução do regime e seu impacto na política externa brasileira. Brasília, Funag, 2009.

FERREIRA VIDIGAL, Armando Amorim... \{ et al \} Amazônia Azul, o mar que nos pertence. Editora Record. Rio de Janeiro, 2006.

FERREIRA, Oliveiros S. A crise da política externa: autonomia ou subordinação? Editora Revan, 2001. . Forças Armadas para que? São Paulo, Edições GRD, 1988.

FIORI, José Luis. Guerra na África é nova corrida imperialista, diz Fiori. Entrevista a Folha.com in www.1.folha.uol.com.br, acessado em 04/04/2011. Caleidoscópio mundial. Valor Econômico, 29/12/2010, p.A11. ., MEDEIROS, Carlos \& SERRANO, Franklin. $O$ mito do colapso do poder americano. Editora Record, 2008.

São Paulo: 2007. O poder global e a nova geopolítica das nações. Boitempo Editorial. . O Brasil e seu "entorno estratégico" na primeira década do século XXI in Sader, E. Lula e Dilma. São Paulo, Boitempo Editorial, 2013. . O Brasil e a África negra. Valor Econômico, 27/11/2013, p. A15.

FONSECA JR., Gelson. A Legitimidade e outras questões internacionais. Editora Paz e Terra. São Paulo: 2004

FREYRE, Gilberto. Casa Grande e Senzala: introdução à história da sociedade patriarcal no Brasil. Rio de Janeiro: Editora Record, 1998.

1949. Nação e Exército. Livraria José Olympio Editora, Rio de Janeiro, A propósito de José Bonifácio. Recife: MEC - Instituto Joaquim Nabuco, 1972. 
FRIEDMAN, George. Os próximos 100 anos - uma previsão para o século XXI. Editora Best Business, Rio de Janeiro, 2009.

\& FRIEDMAN, Meredith. Poder mundial - a tecnologia e o domínio dos Estados Unidos no século XXI. Biblioteca do Exército Editora. Rio de Janeiro, 2009.

FICHTE, Johann G. Discursos a la Nacion Alemana. Editora Tecnos, Madrid, 2002.

GOÉS MONTEIRO. General Pedro Aurélio. A Revolução de 30 e a Finalidade Política do Exército: esboço histórico. Adersen Editores, Rio de Janeiro, 1931.

GUIMARÃES, Samuel Pinheiro. Quinhentos anos de periferia. Porto Alegre/Rio de Janeiro, Editora da Universidade UFRGS/ Contraponto, 1999.

Janeiro, Contraponto, 2005. Desafios Brasileiros na era de gigantes. Rio de junho de 2012. Relatório ao Conselho de Ministros. MERCOSUL,

GUGLIALMELLI, Juan Enrique. Geopolitica del cono sur. El Cid Editor, Buenos Aires, 1979.

HURREL, A. [et al.] Os BRICS e a ordem global. Rio de Janeiro: Editora FGV, 2009. $168 \mathrm{p}$.

HONÓRIO RODRIGUES, José. Interesse nacional e política externa. Editora Civilização Brasileira. Rio de Janeiro, 1966.

HUGON, Philippe. Geopolitica da África. Editora FGV, Rio de Janeiro, 2009.

HUNTINGTON, Samuel P. O Choque de Civilizações e a recomposição da ordem mundial. Biblioteca do Exército Editora. Rio de Janeiro: 1998.

HERMANN, Breno. Soberania, não intervenção e não indiferença: reflexões sobre o discursos diplomático brasileiro. Brasília, Fundação Alexandre de Gusmão, 2011. 
IHGB - INSTITUTO HISTÓRICO E GEOGRAFICO BRASILEIRO. O Patriarcha da Independência, José Bonifácio de Andrada e Silva. Brasiliana, vol. 166. Companhia Editora Nacional, 1939.

Indústria e Desenvolvimento Produtivo no Brasil / Nelson Barbosa, Nelson Marconi, Mauricio Canêdo Pinheiro, Laura Carvalho; organização. - 1.ed. - Rio de Janeiro: Elsevier: FGV, 2015.

JALIFE-RAHME, Alfredo. El hibrido mundo multipolar - un enfoque multidimensional. Orfila, Ciudad de Mexico, 2010.

JOBIM, Nelson, Etchegoyen, Sergio W. e Alsina, João Paulo (orgs.). Segurança Internacional: perspectivas brasileiras. Rio de Janeiro: Editora FGV, 2010.

KENNAN, George. Around the Cragged Hill: A Personal and Political Philosophy. Londres: Norton paperback, 1993. 272 p.

KHANNA, Parag. Connectography: mapping the future of global civilization. Random House, New York, 2016.

KLARE, Michael. The race for what's left: the global scramble for he world's last resources. Metropolitan Books, NY, 2012.

KAGAN, Robert. El retorno de la Historia y el Fin de los Sueños. Ciudad de México, Taurus, 2008.

KANT, Immanuel. À paz perpétua. L\&PM Editora, Porto Alegre, 2008.

KAPLAN, Robert D. The Geography of Chinese Power. Foreign Affairs, volume 89, number 3, page 22-41. New York: may/june 2010.

La venganza de la geografia. Como los mapas condicionam el destino de las nacionais. Barcelos, RBA Libros, 2013.

KENNEDY, Paul. Ascensão e Queda das Grandes Potencias: transformação econômica e conflito militar de 1500 a 2000. 2ed, Rio de Janeiro: Campus, 1989. 
KHANNA, Parag. O Segundo mundo. São Paulo: Editora Intrínseca, 2008.

KISSINGER, Henry. Diplomacia. Gradiva, Lisboa, 2007.

O mundo restaurado. Livraria José Olympio Editora, Rio de Janeiro,

1973.

Precisará a América de uma política externa? Uma diplomacia para o século XXI. Lisboa, Editora Gradiva, 2003.

LATHAM, Andrew, The Confucian Continuities of Chinese Geopolitical Discourse. Saint Paul, Macalester International, vol. 18, nº1, 2007, 246.

LACOSTE, Yves. Geopolítica - la larga história del presente. Editorial Sintesis, Madrid, 2008.

. A geografia - isso serve, em primeiro lugar, para fazer a guerra.

Editora Papirus, Campinas, 2010.

LESSA, Carlos (org). Enciclopédia de brasilidade: auto-estima em verde amarelo. Rio de Janeiro: Casa da Palavra, 2005.

.A inferioridade brasileira, uma conveniente convicção da elite. Jornal Valor Econômico, edição eletrônica, 02/08/2006, acessada em 02/08/2006.

LESSA, Renato \& BUARQUE DE HOLLANDA, Cristina. San Tiago Dantas coletânea de textos sobre política externa. Fundação Alexandre de Gusmão, Brasília, 2009.

LIGTH, Kenneth (organizador). A Transferência da capital e corte para o Brasil, 18071808. Lisboa: Editora Tribuna da História, 2007.

MARQUES, Adriana A. Concepções de Defesa Nacional no Brasil: 1950-1996. Unicamp. 2001

MACKINDER, Halford J.: Democratic Ideals and Reality. Henry Holt and Company. New York, 1942.

: El Mundo Redondo y la Conquista de la Paz in Política y Poder em um Mundo mas Chico. Weigert, Hans W. y Stefansson, Vilhjalmur (org.). Editorial Atlântida. Buenos Aires, 1948. 
: El Eje Geográfico de la Historia in Antologia Geopolítica.

Rattenbach, Augusto B. (org.). Editorial Pleamar. Buenos Aires, 1985.

MARCIAL, Elaine C. \& GRUMBACH, Raul José S. Cenários Prospectivos - como construir um futuro melhor. Rio de Janeiro, FGV Editora, 2008.

MARINI, Cel. José Felipe. El conocimiento geopolítico. Fuerza Aerea Argentina, Escuela Superior de Guerra Aerea, Buenos Aires, 1980.

MAGNOLI, Demétrio (org.) História das Guerras. Editora Contexto, São Paulo: 2006 História da Paz. Editora Contexto, São Paulo: 2008.

MAFRA, Roberto Machado de Oliveria. Geopolítica - introdução ao estudo. Sicurezza Editora, São Paulo: 2006.

MAHAN, Alfred Thayer: The Influence of Sea Power upon History 1660-1805. PrenticeHall Inc., Hong Kong, 1984.

MARTINS FILHO, J. R. “As Forças Armadas brasileiras no pós-guerra fria”, disponível em http://www.tensoesmundiais.net/index.php/tm

MARTIN, André Roberto. Brasil, Geopolítica e Poder Mundial: o anti-Golbery. Mimeo, 2007. Fronteiras e Nações. São Paulo, Contexto, 1997.

MARÇAL BRANDÃO, Gildo. Linhagens do pensamento político brasileiro. São Paulo, Editora Hucitec, 2007.

MATHIEU, Hans \& GUARNIZO, Catalina Niño. Anuário 2010 de la seguridad regional de América Latina y el Caribe. Friedrich Ebert Stiftung. Bogotá, 2010.

Manual Básico / Escola Superior de Guerra. - Rev., atual. - Rio de Janeiro, 2014. 4 v 
MAZZUCATTO, Mariana. O Estado Empreendedor - desmascarando o mito do setor público vs. Setor privado / tradução Elvira Serapicos. - $1^{a}$ ed. - São Paulo: Portfolio Penguin, 2014.

MEARSHEIMER, John J. A tragédia da política das grandes potências. Editora Gradiva, Lisboa, 2007.

MEAD, Walter Russell. The return of Geopolitics. The revenge of the Revisionist Powers. Foreign Affairs, may/june 2014, Volume 93, number 3.

MEIRA MATTOS, Carlos de. Geopolítica e modernidade - geopolítica brasileira. Biblioteca do Exército Editora, Rio de Janeiro, 2002.

Buenos Aires, 1997. Geopolitica y teoria de las fronteras. Circulo Militar,

Editora, Rio de Janeiro, 1984. - Geopolítica e Trópicos. Biblioteca do Exército Uma geopolítica pan-amazônica. Biblioteca do Exército

Editora, Rio de Janeiro, 1980. . A geopolítica e as projeções do poder. Biblioteca do Exército Editora, Rio de Janeiro, 1977. Brasil, Geopolítica e Destino. Livraria José Olympio Editora, Rio de Janeiro: 1975.

MELLO, Leonel Itaussu Almeida. Quem tem medo da Geopolítica?. São Paulo: Editora Hucitec e EdUSP, 1999.

Editorial Annablume, São Paulo, 1996. Argentina e Brasil - a balança de poder no cone sul.

MEDEIROS, C. A. A guerra e o desenvolvimento tecnológico americano. Texto apresentado ao Seminário sobre os EUA, julho de 2007. Disponível em www.funag.gov.br (acessado em 15/11/2014).

MONIZ BANDEIRA, Luiz Alberto. Geopolítica e política exterior - Estados Unidos, Brasil e América do Sul. Fundação Alexandre de Gusmão, Brasília, 2009.

O Brasil como potência regional e a importância estratégica da América do Sul para sua política exterior in www.amersur.com.ar, acessado em fevereiro de 2009. 
La importancia geopolítica de América del Sur, en

la estratégia de los Estados Unidos in www.amersur.com.br, acessado em fevereiro de 2009.

MIYAMOTO, Shiguenoli. Geopolítica e poder no Brasil. São Paulo: Papirus Editora, 1995.

. Os estudos geopolíticos no Brasil: uma contribuição para sua avaliação. Perspectivas, São Paulo, p.75-92, 1981.

MORGENTHAU, Hans J. A Política entre as Nações. Editora Universidade de Brasília/Instituto de Pesquisas de Relações Internacionais. Brasília - São Paulo: 2003.

MOREIRA BENTO, Claudio \& CAMINHA GIORGIS, Luiz Ernani. Brasil: lutas contra invasões, ameaças e pressões externas. Academia de História Militar Terrestre do Brasil, Resende, 2014. . As batalhas de Guararapes - descrição e análise militar. Universidade Federal de Pernambuco, Recife, 1971.

NATIONAL SECURITY STRATEGY. The White House, may 2010. Acessado em $15 / 01 / 2011$.

NYE JR. Joseph S. Cooperação e conflito nas relações internacionais. Gente editora, São Paulo, 2009.

OLIVEIRA, Eliézer Rizzo de (Org.). Segurança e Defesa Nacional: da competição à cooperação regional. São Paulo: Fundação Memorial da América Latina, 2007.

O futuro da Indústria no Brasil: desindustrialização em debate / Edmar Bacha e Monica Baumgarten de Bolle (org.) - Rio de Janeiro: Civilização Brasileira, 2013.

PAIM, Maria Augusta. O Petróleo no Mar. Rio de Janeiro: Renovar Editora, 2011.

PATRIOTA, Antonio de Aguair. O Conselho de Segurança após a Guerra do Golfo - a articulação de um novo paradigma de segurança coletiva. Fundação Alexandre de Gusmão, Brasília, 2010. 
PAROLA, Alexandre Guido Lopes. A ordem injusta. Fundação Alexandre de Gusmão, Brasília, 2007.

PENHA, Eli Alves. Relações Brasil - África e a geopolítica do Atlântico Sul. Salvador, Edufba, 2011.

A criação do IBGE no contexto da centralização política do Estado Novo. Dissertação de mestrado apresentada junto a Universidade Estadual do Rio de Janeiro, 1992.

PEZARAT CORREIA, Pedro de. Manual de Geopolítica e Geoestratégia - Volume 1. Editora Almedina, Lisboa, 2010.

PIMENTEL, José Vicente de Sá Pimentel (org.). Debatendo o BRICS. Brasília: FUNAG, 2013. $284 \mathrm{p}$.

RAUEN, André Tortato (org.). Políticas de Inovação pelo lado da demanda no Brasil. Brasília, IPEA, 2017.

ROBERT MORAES, Antônio Carlos. Ratzel. São Paulo, Editora Ática, 1990.

REBELO, Aldo. Raposa-Serra do Sol - o índio e a questão nacional. Editora Thesaurus, São Paulo, 2010. . \& FERNANDES, Luis. Política de Defesa para o século XXI. Câmara dos Deputados, Brasília, 2003. . Um brasileiro que honrou a espécie. Diário de São Paulo, 13/07/13, p.

4.

RODRIGUES, José Honório. Conciliação e reforma no Brasil. Rio de Janeiro: Nova Fronteira, 1982.

RIBEIRO, Darcy. O Povo brasileiro. São Paulo: Editora Schwarcz, 2006.

ROCHA FILHO, Álvaro \& GARCIA, João Carlos Vitor. Renato Archer: energia atômica, soberania e desenvolvimento - depoimento. Contraponto, Rio de Janeiro, 2006. 
SANTIAGO DANTAS, Francisco Clementino. Poder nacional, cultura política e paz mundial. Conferencias de San Tiago Dantas na Escola Superior de Guerra (1951-1962). Rio de Janeiro, ESG, 2014.

SILVA, José Bonifácio de Andrada. Projetos para o Brasil; organização Miriam Dolhnikoff. São Paulo: Companhia das Letras, 1998.

. Obras científicas, políticas e sociais; Edgard de

Cerqueira Falcão (org.). 3 volumes. Brasília: Câmara dos Deputados, 2006.

SOMBRA SARAIVA, J. F. África parceira do Brasil Atlântico. Relações internacionais do Brasil e da África no início do século XXI. Belo Horizonte: Belo Traço Editora, 2012.

SOUSA, José Tarquino de. Coleção Documentos Brasileiros. José Bonifácio 1763 1838. Rio de Janeiro: José Olympio Editora, 1945.

SANTOS, Milton. Por uma outra globalização: do pensamento único à consciência universal. Record. São Paulo. 2000,

SECRETARIA DE ASSUNTOS ESTRATÉGICOS. Brasil 2022. Brasília, 2010.

SELSER, Gregorio. Cronologia de las intervenciones estranjeras en América Latina. Quatro tomos, 1776-1990. Universidad Autonoma de la Ciudad de Mexico, Ciudad de Mexico, 2010.

SEVERSKY, Major A. P.. A vitória pela força aérea. Editora Itatiaia e Instituto Histórico Cultural da Aeronáutica. Belo Horizonte - Rio de Janeiro, 1988.

SPEKTOR, Matias. O PROJETO AUTONOMISTA NA POLÍTICA EXTERNA BRASILEIRA in Política Externa, Espaço e Desenvolvimento - livro 3. Aristides Monteiro Neto / IPEA, Brasília, 2014 .. Kissinger e o Brasil. Zahar Editora, Rio de Janeiro, 2009.

Janeiro: 2010 . (org.). Azeredo da Silveira - um depoimento. Editora FGV. Rio de

SILVA, Othon Luiz Pinheiro da. Submarino de propulsão nuclear no Brasil. Revista do Clube Naval, 1994. 
SPYKMAN, Nicholas J. Estados Unidos frente al mundo. Fondo de Cultura Económica, Ciudad de México, 1944.

STUENKEL, Oliver. BRICS e o futuro da ordem global. São Paulo, Editora Paz e Terra, 2017.

SOMBRA SARAIVA, José Flávio. África parceira do Brasil atlântico: relações internacionais do Brasil e da África no início do século XXI. Brasília: Editora Fino Traço, 2012.

TELEMBERG, Marcia Stein (coord.). Amazônia Azul: a última fronteira. Centro de Comunicação Social da Marinha, Brasília, 2013.

TRAVASSOS, Mário. Projeção Continental do Brasil. Livraria José Olympio Editora, Rio de Janeiro, 1938.

Introdução à geografia das comunicações brasileiras. Livraria José Olympio Editora, Rio de Janeiro, 1942.

TEIXEIRA DA SILVA, Francisco Carlos, CABRAL, Ricardo Pereira \& MUNHOZ, Sidnei J. Impérios na história. Editora Campus, Rio de Janeiro, 2009.

TOSTA, Cel. Octavio. Teorias geopolíticas. Rio de Janeiro, Biblioteca do Exército, 1984.

VIZENTINI, Paulo Fagundes. Relações Internacionais do Brasil, de Vargas a Lula. São Paulo: Editora Fundação Perseu Abramo, 1996, 2ª edição. 127 p.

VESENTINI, José William. Novas Geopolíticas. São Paulo: Editora Contexto, 2008

VIEIRA, Maria Graciana Espellet de Deus. Formação social brasileira e geografia: reflexões sobre um debate interrompido. Dissertação de Mestrado apresentada em 1992 à Universidade Federal de Santa Catarina.

VILELA LUZ, Nicia. A luta pela industrialização no Brasil. Editora Alfa Ômega, 1975; 
VILLA, Rafael Antônio Duarte. Da crise do realismo à segurança global multidimensional. Annablume Editora, São Paulo: 1999.

WEFFORT, Francisco C. Formação do pensamento político brasileiro, Ideias e personagens. São Paulo: Editora Ática, 2006b

WALTZ, Kenneth N. Teoria Das Relações Internacionais. Editora Gradiva, Lisboa, 2002. Structural realism after the Cold War. International Security, v. 25, n.1, p. 5-41, 2000.

ZAKARIA, Fereed. O Mundo pós-americano. São Paulo, Companhia das Letras, 2008. 